Portland State University

PDXScholar

1983

\title{
A translation into English of the German novel Jakob der Lügner by Jurek Becker
}

Harriet Passell

Portland State University

Follow this and additional works at: https://pdxscholar.library.pdx.edu/open_access_etds

Part of the German Literature Commons

Let us know how access to this document benefits you.

\section{Recommended Citation}

Passell, Harriet, "A translation into English of the German novel Jakob der Lügner by Jurek Becker" (1983). Dissertations and Theses. Paper 3258.

https://doi.org/10.15760/etd.3249

This Thesis is brought to you for free and open access. It has been accepted for inclusion in Dissertations and Theses by an authorized administrator of PDXScholar. Please contact us if we can make this document more accessible: pdxscholar@pdx.edu. 
AN ABSTRACT OF THE THESIS OF Harriet Passell for the Master of Arts in German presented October 21, 1983.

Title: A translation into English of the German novel Jakob der Lügner by Jurek Becker.

APPROVED BY MEMBERS OF THE THESIS COMMITTEE:

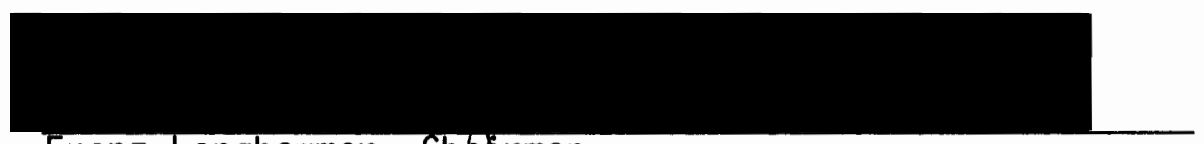

Franz Langhammer, Chairman

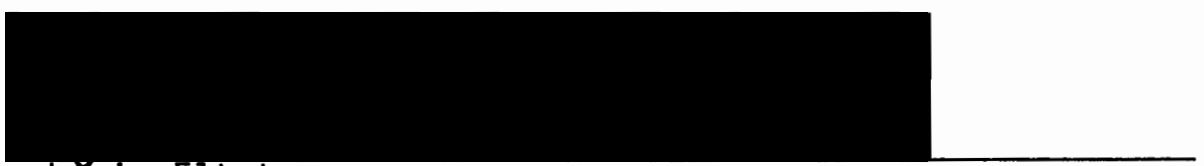

$$
\text { Louis Elteto }
$$

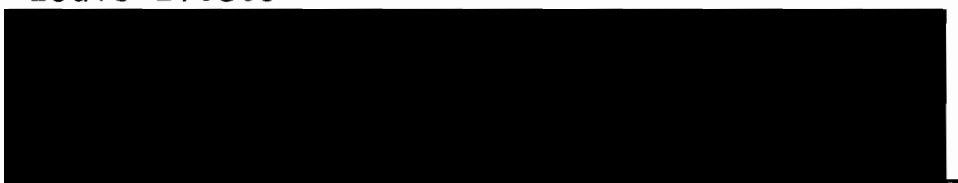

Linda Parshaltc

This thesis is a translation of the German novel Jakob der Lügner ${ }^{1}$ by Jurek Becker. In my commentary I have tried to explain why I undertook the project of translating this novel from German into English, when that had already been done by Melvin Kornfeld. 2 Kornfeld's translation, which is no longer in print, fails to do justice

1Jurek Becker, Jakob der Lügner, (Frankfurt am Main: Suhrkamp Verlag, 1980).

2Jurek Becker, Jacob The Liar, trans. Melvin Kornfeld (New York and London: Harcourt Brace Javanovich, 1975). 
to Jurek Becker's style and changes a story of heartwarming simplicity, humor and psychological insight into a somewhat tedious account of the life in a ghetto during World War II. This change is brought about in the following ways:

1. Kornfeld's vocabulary does not correspond to the fairly simple every-day level of language typical of the characters in Jakob der Lügner, but has a tendency to slip into a choice of words more erudite than the original.

2. This rather erudite choice of words conflicts with the extremely simple sentence structure which Kornfeld imposes on the transiation by changing many of Becker's commas into periods. This change in punctuation also destroys the very fine technique of the interior monologue, which, in the original, is presented as a rambling of thoughts on the part of one of the characters or a chain of associations of which each link is separated from the next by a comma. A period then closes off this inner monologue and the narration proceeds. By using periods to separate both the thoughts of the characters from one another and the whole chain of thoughts from the narration, Kornfeld destroys the inner monologue and the characters become pale replicas of their originals.

3. Kornfeld's change in verb tenses (usually from German perfect tense to English pluperfect or from German present to English past tense) also contributes to this destruction of the inner monologue. Through switching, for example, from a past into a 
present tense, Becker lays down his role as narrator, in order to give the floor to one of his characters, whose thoughts he then expresses as though he or she were actually speaking. By avoiding such a tense switch, Kornfeld again fails to distinguish between narration and direct testimony from one of the characters.

4. Kornfeld's lack of familiarity with German idiomatic expressions leads him to make many mistakes, either in meaning or in the tone intended by the author.

Keeping these points in mind, I have tried to write a translation that would do more justice to Jurek Becker's original work. 
A TRANSLATION INTO ENGLISH OF THE GERMAN NOVEL JAKOB DER LÜGNER BY JUREK BECKER

by

HARRIET PASSELL

A thesis submitted in partial fulfillment of the requirements for the degree of

MASTER OF ARTS

in

GERMAN

Portiand State University

1983 
TO THE OFFICE OF GRADUATE STUDIES AND RESEARCH:

The members of the committee approve the thesis of Harriet Passell presented October 28, 1983.

Franz Langhammer, Chairman

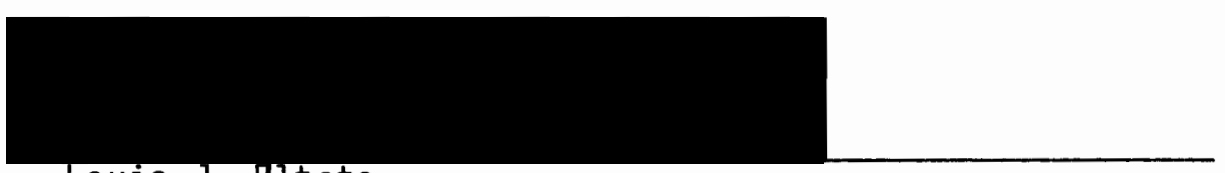

Louis J.HIteto

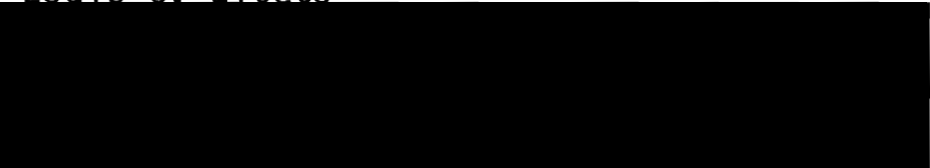

Linda Parshall

APPROVED :

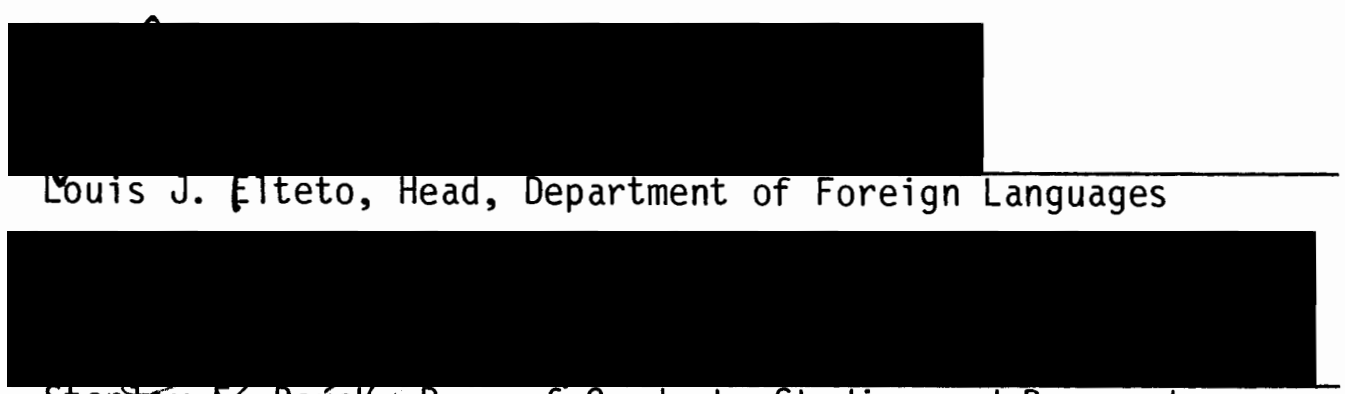

Stantey E. Rauck, Dean of Graduate Studies and Research 
Vorliegende Übersetzung wurde vom Prüfungsausschuss als hervorragende schöpferische Leistung bewertet und anerkannt, obgleich sie vom allgemein üblichen Format einer Magisterarbeit abweicht.

Für den Prüfungsausschuss

Franz Langhammer

Professor of German 
INHALTSVERZEICHNIS

SEITE

Übersetzung ............................. 1

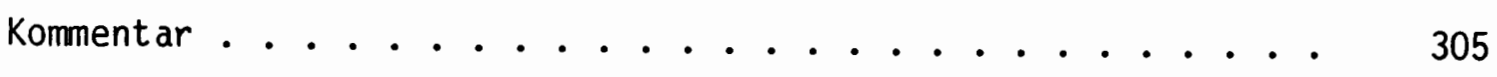

Bibliographie........................... 329 
UBERSETZUNG 
I can already hear everybody say: A tree, 'so what, a trunk, leaves, roots, little bugs under the bark, and, if you are lucky, a respectably shaped crown, so? I hear them say: Don't you have anything better to think about to make your eyes light up like a hungry goat's when one shows it a fat bunch of grass? Or do you mean a particular tree, a very specific one, which has, maybe, what do I know, given its name to a battle, like the Battle of the Lone Pine, do you mean one like that? or was someone famous hanged on it? All wrong, not even hanged? Okay then, it's pretty simple-minded, but if it gives you such pleasure, let's keep playing this silly game for another while, just as you like. Is what you mean really the slight noise people call a rustle, when the wind has found your tree, when it leafs through it, one might say? or the amount of useable lumber contained in its trunk? Or do you mean the proverbial shade it casts? Because as soon as people speak of shade, everybody thinks of trees, oddly enough, even though houses or factories give much more shade. Do you mean the shade?

All wrong, I say, you can stop guessing, you won't hit on it. I don't mean anything of the kind, even though the heating factor is not to be underestimated, I simply mean a tree. I have my reasons for that. First of all trees have played a certain role in my life, I may be overrating it, but that is how I feel about it. At the age of nine I fell out of a tree, an apple tree as a matter of fact, and I broke my left hand. Everything healed up pretty well, but there are a few difficult movements which I haven't been able to make with the fingers of my hand since. I mention this because it had been taken for granted that I was to become a violinist some day, but otherwise that is of no importance. My mother wanted it first, then my father wanted it too, 
and finally all three of us wanted it. Okay then, no violinist after all. A few years later, I must have been seventeen already, I was, for the first time in my life, lying under a tree with a girl. This time it was a beechtree, a good fifteen meters high, the girl's name was Esther, no, I think it was Moira, but anyway it was a beechtree and a wild boar interrupted us. Maybe there were several, we didn't have a chance to turn around. And again a few years later my wife Chana was shot under a tree. I can't tell you what kind of tree it was this time, I was simply told of it and I forgot to ask about the tree.

And now for the second reason why my eyes light up when I think of this tree, possibly or even quite certainly the more important one of the two. For in this ghetto trees are forbidden (Regulation 31: "It is strictly forbidden to keep ornamental and any other kinds of plants within the ghetto area. This also applies to trees. Should any plants have been overlooked in setting up the ghetto, they are to be removed immediately. Violators will be. . .").

That was Hardtloff's idea, the devil knows why, maybe because of the birds. And actually a thousand other things are prohibited as well, rings and other valuables, the keeping of pets, being on the street after eight--there would be no point in naming them all. I try to imagine what would happen to somebody who wore a ring and was seen with a dog after eight. But no, I don't try to imagine that at all, I am not even thinking of rings and dogs and the time of day. I am only thinking of this tree, and my eyes light up. I can understand everything, I mean theoretically I can: You guys are Jews, you are less than a piece of dirt, what do you need rings for, and why do you have to hang around the 
streets after eight? We are planning this and that for you and want to do it in such and such a way. I can understand that. I cry about it, I would kill them all if I could. I would wring Hardtloff's neck with my left hand (which can no longer make certain movements with its fingers), still, I can understand it. But why do they forbid us trees?

I have already tried a thousand times to get this damn story off my mind, always without success. Either they weren't the right people I wanted to tell it to, or I made some kind of mistake. I mixed up a lot of things: I confused names, or, as. I said, they weren't the right people. Every time I've had a few drinks it's there, there is nothing I can do about it. I shouldn't drink so much, each time I think: they've got to be the right people, and I think I've got it all beautifully straight and nothing can happen in the course of my telling it.

Actually, when you look at him, Jacob doesn't remind you of a tree at all. You know, there are men of whom one says: a fellow built like a tree, big, strong, a bit awesome, the kind you'd like to be able to lean on for a few minutes every day. Jacob is much smaller and wouldn't reach up to that fellow's shoulders. He is scared like all of us, he is really no different from Kirschbaum or from Frankfurter or from me or from Kowalski. The only thing that distinguishes him from the rest of us is that without him this goddamed story couldn't have happened. But even that is a matter of opinion.

Well, it's evening. Don't ask for the exact time, only the Germans know that, we don't have any watches. It got dark a good while ago, there are lights on in a couple of windows, that will have to do. 
Jacob is hurrying, he doesn't have much time left, it got dark quite a while ago already. And all of a sudden he has no more time at all, not even half a second, because it turns bright all around him. That happened in the middle of the Damm der Kurlandischen, close to the edge of the ghetto, where the ladies' dress shops used to be. There is the sentry, five meters above Jacob on a wooden tower behind the barbed wire which has been strung right across the street. At first he says nothing, he just fixes Jacob with the searchlight in the middle of the street, and waits. To the left in the corner is the shop that used to belong to Mariutan, an emigrant Romanian, who in the meantime has had to return to Romania to defend his country's interests at the front. And to the right is the former shop of Tintenfass, a local Jew, who meanwhile has settled in Brooklyn, New York, and continues to sew topnotch ladies' dresses. And just in between on some cobblestones and all alone with his fear stands Jacob Heym, already too old for such mental strain, pulling his cap off $h$ is head, unable to make out anything in this glare, only sure that somewhere in all this brightness there are two soldier's eyes that have found him. Jacob searches his mind for his most recent transgressions but cannot think of any. He has his ID card with him, he did not miss work, the star on his chest is sitting in exactly the proper place, he takes one more look at it, and the one on his back he just sewed on two days ago. If the man doesn't shoot right away Jacob can answer all his questions to his satisfaction, so why doesn't he go ahead and ask.

"Am I wrong, or is it forbidden to be out on the street after eight?" the soldier says at last. One of the friendly sort, the voice 
doesn't even sound angry, gentle rather, one would like to chat a while and let some humor enter into it.

"It is forbidden," says Jacob.

"And what time is it now?"

"I don't know."

"But you should know that," says the soldier.

Jacob could now say, "That's true," or he could ask, "How?" or he could ask, "Well, what time is it?" Or he could be silent and wait, and that's what he does, that seems the most appropriate to him.

"Do you at least know what kind of a house that is over there?" asks the soldier, after he has perhaps noticed that his partner isn't the man to keep a conversation going. Jacob knows it. He didn't see in what direction the soldier nodded his head or pointed his finger, he ony sees the bright searchlight, behind him are many houses, but in the present situation it can only mean one.

"The police station," says Jacob.

"You go in there now. Go and report to the officer on duty and tell him that you were out on the street after eight, and ask him for a just punishment."

The police station. Jacob doesn't know a whole lot about this house, he knows that some sort of German administration is in there, that's what they all say, anyhow. What is being administered there, no one knows. He knows that it used to be the Revenue Office, he knows that there are two exits, one at the front and one leading out of the ghetto. And most of all he knows that the chance of coming out of this house alive if you are a Jew is very slight. To this day no such case has been known. 
"Is anything the matter?" asks the soldier.

"No."

Jacob turns around and leaves. The searchlight accompanies him, warns him of unevennesses in the pavement, lets his shadow get longer and longer, lets the shadow reach the heavy iron door with the little round peephole and climb up it, while Jacob still has many steps to go. "And what do you ask for?" asks the soldier.

"For a just punishment."

He doesn't yell, only undisciplined or disrespectful people yell, but he doesn't say it too softly either, so that the man in the light can clearly understand him across the distance, he tries hard to find just the right tone of voice. It has to be clear that he knows what he is supposed to say, that he only needs to be asked.

Jacob opens the door, closes it again quickly between himself and the searchlight and looks at the long empty hallway. He has been here many times before, on the left hand side, right next to the door, used to be a little table, behind it sat a clerk, ever since Jacob can remember it used to be Mr. Kominek, who always asked everyone coming in: "What can we do for you?" "I would like to pay my taxes for the next six months, Mr. Kominek," Jacob would answer. But Kominek would pretend that he had never seen Jacob before, even though from October unt il the end of April he had been in Jacob's cafe almost every week to eat potato pancakes. "Type of occupation?" Kominek would ask. "Small business," Jacob would answer. He wouldn't show his annoyance, not in the least, Kominek could handle at least four pancakes each time and sometimes he even brought his wife along. "Name?" Kominek would then ask. "Heym, 
Jacob Heym." "Letters F to K: room sixteen." But whenever Kominek came to the cafe he didn't really order potato pancakes, he just said "Same as usual." Because he was a regular.

In the spot where the table used to be there is no table any more, but where its legs were one can see four indentations in the floor. But the chair didn't leave any marks, probably because it didn't stand tenaciously in the very same place the way the table did. Jacob leans against the door and rests a while, the last few minutes weren't easy, but what does it matter now. The smell in this house has changed, it's somehow better. The stench of ammonia, which used to hang in the hallway, is gone, and it smells strangely more civilized. Leather is in the air, woman's sweat, coffee, and a whiff of perfume. Way down the hall a door is opened, a woman in a green dress comes out, walks a few steps, she has nice straight legs, goes into another room, two doors stay open, one hears her laugh, she comes back out of the room, goes back again, the doors are closed again, the hallway is empty. Jacob is still leaning against the iron door. He feels like going outside, maybe the searchlight won't be waiting for him any more, maybe it has found something else, but then again perhaps it is still waiting, it seems pretty unlikely that it wouldn't be waiting any more, the soldier's last question sounded so final.

Jacob goes into the hallway. It doesn't say on the doors who is behind them, only numbers. The officer on duty probably has the room that used to be the revenue director's, but that is not certain, and it isn't too good an idea to knock at the wrong door. What do you want, some information? Did you hear that, he wants information! 
We are planning this and that for him, and he just walks in and wants information!

Behind number fifteen, once Small Businesses, Letters $A$ to $E$, Jacob hears noises. He puts his ear to the door, tries to listen, can't understand a thing, only words that make no sense, but even if the wood were thinner it wouldn't help, because who would ever address another with "Mr. Officer on Duty?!" Suddenly the door opens, number fifteen of all things, luckily the doors here open towards the outside, so that the person coming out doesn't see Jacob, who is hidden behind. It is also lucky that this person leaves the door open, he'll probably be right back, when you're among your kind you leave the doors open, and Jacob is behind cover. Inside a radio is on, there is a crackle, must be one of their Popular Radios, but no music. Jacob hasn't heard any music since he has been in the ghetto, none of us have, only when someone was singing. An announcer is reporting unimportant things from headquarters, somebody was promoted to lieutenant colonel after his death, then comes something about assured supplies for all civilians and then the following news has just reached the announcer: "In a bitter defensive battle our heroic troops succeeded in bringing the Bolshevik attack to a halt twenty kilometers before Bezanika. In the course of combat, which on our side. . " Then the person is back in his room, shuts the door and the wood is too thick. Jacob stands motionless, he has heard a lot, Bezanika is not far from here, not exactly a stone's throw, no, but not so terribly far. He has never been there, he has only heard of it, it's a very small town, if one takes the train by way of Mieloworno, southeast through the market town of Pry, where his 
grandfather (on his mother's side) had a pharmacy, and then transfers towards Kostawa, one has to reach Bezanika some time. It's maybe four hundred kilometers or even five hundred away, hopefully no more, and that is where they are. A dead man has heard some good news and rejoices, he would like to rejoice a bit longer, but in these circumstances. - The officer on duty is waiting for him, and Jacob has to keep going. The next step is the hardest, Jacob tries it, but without success. His sleeve is caught in the door, the fellow who came back into the room has caught him, with no evil intent, he simply closed the door behind himself, and Jacob is trapped. He pulls gently, the door is well made, it fits exactly, no superfluous gaps, not even a sheet of paper could slip through it. Jacob would like to cut off that part of the sleeve, his knife is at home and with half his teeth missing, there is no point. He hits on the idea of taking his jacket off, just taking it off and leaving it stuck, what does he need a jacket for now? He has already slipped off one sleeve when he suddenly remembers that he will need the jacket after all. Not for the coming winter, if we're still around, the next frost inspires no fear, no, the jacket is necessary for the officer on duty (in case one ever finds him), for the officer on duty who can surely stand the sight of a Jew without a jacket (Jacob's shirt is clean and hardly mended), but not the sight of a Jew without a star on chest and back (Regulation $\mathrm{Nr} .1$ ). Last summer the stars were on the shirt, you can still see the sticthes, but not now, now they are on the jacket. And he puts it back on, loyal to his stars, tugs harder, gains a few millimeters, but not enough. The situation is desperate, as they say, he pulls with all his might, something tears, that makes a 
noise, and the door opens. Jacob falls out into the hallway, above him stands a man in civilian clothes and quite amazed, then he laughs and turns serious again. What is Jacob doing here? Jacob gets up and chooses his words very carefully. It is not that he was out on the street after eight, no, the sentry who stopped him had said that it was already eight and he should report to the officer on duty.

"And so you eavesdrop here?"

"I wasn't eavesdropping. I have never been here and I didn't know which room. That is why I was just going to knock here."

The man asks no more, he nods his head toward the hallway. Jacob walks ahead of him until the man says "Here." It isn't the revenue director's room after all. Jacob looks at the man, then knocks. The man walks off again, but from inside no one answers.

"Go on in," says the man and disappears in his door when Jacob turns the doorknob.

Jacob in the officer's room, he stops by the door, ever since he was discovered by the searchlight he hasn't put his cap back on his head. The officer is a rather young man, at most thirty. He has dark brown, almost black hair which curls slightly. His rank can't be seen, he is in shirtsleeves, his jacket is hanging on a wall hook so that one can't see the insignia. Above the jacket hangs the leather belt with the revolver. That somehow doesn't make' sense, it should hang below the jacket, surely one takes the belt off first and then the jacket, but it does hang above. The officer is lying on the black leather sofa, sleeping. Jacob thinks that he is sleeping deeply, Jacob has heard many 
people sleep before, he has an ear for it. He is not snoring, but he is breathing deeply and regularly, Jacob will have to make himself known somehow. Usually one clears one's throat, but that won't do, one does that when one drops in on good friends. That is, when one drops in on a very good friend, one doesn't clear one's throat either, one says "Wake up, Solomon, I am here," or one just taps him on the shoulder. But anyway, throat clearing won't do, it lies just about halfway between here and Solomon. Jacob is about to knock at the door, he lets his hand drop, he sees that on the desk is a clock with its back turned towards him. He has to know what time it is, there isn't anything he has to know as urgently right now. The clock says $7: 36$, Jacob goes quietly back to the door. They've played a joke on you, or rather, not they but only he, the one behind the searchlight, he played a joke on you and you fell for it.

Jacob has twenty-four minutes left, if they're decent about it even twenty-four minutes plus the time he has already spent here, he still doesn't knock, he recognizes the black leather sofa the officer is lying on. He has sat on it himself, it used to belong to Rettig, the broker Rettig, one of the richest men in town. Jacob borrowed money from him in the fall of 35 , at twenty percent interest, when the whole summer was so chilly that one could hardly sell any ice cream. His earnings were smaller than ever, not even his famous raspberry ice cream would sell, Jacob had to start with potato pancakes in August already but didn't have any money saved up for potatoes so early in the year and had to borrow. And that's the sofa he sat on in February 36, when he brought Rettig the money back. It used to be in his vestibule, Jacob 
sat on it for an hour waiting for Rettig. He was even wondering about the waste, one could easily have made two coats or three jackets out of the leather, and in a vestibule of all places. The officer turns on his side, sighs, smacks his lips a few times, out of his pocket slips a cigarette lighter and falls to the floor. Jacob really must waken him now, it wouldn't be good if he just woke up without Jacob's waking him. He knocks from inside against the door, the officer says "Yes?", moves, sleeps on. Jacob knocks again, how can anyone sleep so soundly, he knocks hard, the officer sits up before he has really fully woken up, rubs his eyes and asks "What time is it?"

"It is a few minutes past seven-thirty," says Jacob.

The officer quits rubbing his eyes, sees Jacob now, rubs his eyes again, doesn't know whether to be angry or to laugh, that has never happened yet, who would believe a thing like this. He gets up, takes his belt off the hook, then the jacket, puts it on, buckles up the belt. He sits down behind the desk, leans back, stretching out both arms .

"To what do I owe this pleasure?"

Jacob wants to answer, he can't, his mouth is so dry, so this is what the officer looks like.

"No false modesty now," says the officer, "out with it. What's the trouble?"

A bit of saliva collects in his mouth, this is a friendly fellow, maybe he is new here, maybe he doesn't know about the bad reputation this place has. It flashes through Jacob's mind that he might have over-estimated the distance, maybe Bezanika isn't so far away after all, 
perhaps not even 300 kilometers but a good bit less, maybe the man in front of him is scared, a smart man takes precautions, there must be a simple explanation for everything. But then it occurs to him that the report had only just reached the announcer, the officer was sleeping, he couldn't have heard it yet. On the other hand, it might be an advantage that he hasn't heard it yet, the news report spoke of the Russians' having been stopped, successfully stopped, you sure did succeed, maybe he thinks that they are still coming closer. Jacob thinks for too long, the officer is getting impatient, that's not smart, wrinkles are begining to show on his forehead.

"Don't you talk to Germans?"

Of course Jacob talks to Germans, how could he not talk to Germans, for heaven's sake let's not give that impression, we're all reasonable people and can certainly talk to each other.

"The gentleman on sentry duty in the tower in the Kurlandischen said that I was to report to you. He said that I was on the street after eight."

The officer looks at the clock on the table in front of him, pushes back his sleeve and looks at his own watch.

"And that's all he said?"

"He also said that I was to ask for a just punishment."

That answer can't do any harm, thinks Jacob, it sounds obedient, disarmingly honest, anyone showing that much openness might have a right to just treatment, especially if the offense he is being accused of hasn't been committed, any clock can testify to that.

"What is your name?" 
"Heym, Jacob Heym."

The officer takes pencil and paper, writes something down, not only the name, he writes more, looks again at the clock, it's getting later and later, he keeps on writing, almost half a page, then he puts away the paper. He opens a little box, takes out a cigarete and searches in his pocket. Jacob walks to the black leather sofa, bends down, picks the cigarette lighter off the floor, puts it on the table in front of the officer.

"Thank you."

While going back to stand in front of the door, Jacob notices that the hands of the clock on the table have moved past a quarter to eight. The officer lights a cigarette, takes a puff, his fingers play with the lighter, he flicks it on a few times and lets it snap shut, the flame is already quite small.

"Do you live far from here?" he asks.

"Not even ten minutes."

"Go home."

Is one to believe that? How many times has he told that to someone before who still never made it out of here? What will he do with his revolver once Jacob turns around? What is waiting outside in the hallway? What will the sentry do when he sees that Jacob escaped his just punishment? Why should Jacob Heym, of all people this little, unimportant, shaking Jacob Heym with the tears in his eyes, be the first Jew to be able to tell what it looks like inside the police station? It will take six new days of creation, as they say, and the chaos is now even worse than it was back then. 
"Go on, get going," says the officer.

The hallway is empty again, one can almost count on it, let's consider it as a minor source of danger. But then comes the door leading out. Did it make noise when it was opened a while ago, did it open quietly or did it squeak or creak or scrape? Go and notice everything, it's not possible, if at least one knew ahead of time that it will matter later. But will it matter? Thinking it over calmly, it is really of no importance whether it can be opened quietly or not. If it doesn't squeak, it will be opened, and if it squeaks, is Jacob then to just stay here at ten minutes to eight?

The latch is pressed down cautiously, too bad that there isn't another word for cautiously, only very cautiously or infinitely cautiously, all just as far from what is meant. One could perhaps say, open the door quietly and if he hears you, it might cost you your life which has suddenly become meaningful. So he opens it. And then Jacob stands outside, how cold it is all of a sudden, the big square lies there in front of you, what an urge to step out! The searchlight has gotten tired of waiting, it is having fun somewhere else, standing still or resting up for new adventures. Let's stick nice and close to the wall, Jacob, that's it, when you have reached the corner of the house grit your teeth and then twenty meters straight across the square. If it notices something, it'll have to circle and search first, but then the corner will already be there, twenty measly meters.

It is almost exactly twenty meters, I remeasured the distance, exactly nineteen meters and sixty-seven centimeters. I was there, the house is still standing, completely intact, only the sentry tower isn't 
there anymore. But I asked to be shown the exact spot, in the middle of the Damm der Kurlandischen, then I paced off the distance, I am good at estimating a meter. But that wasn't exact enough for me. I bought a tape measure, then I went back and remeasured. The children watched and thought I was an important person and the people looked amazed and thought I was crazy. A policeman even appeared, asked me for my ID card and what I was measuring there, at any rate it is exactly nineteen meters and sixty-seven centimeters, that much is certain.

The house has now been passed, Jacob is preparing for the sprint, within these few minutes before eight nearly twenty meters will have to be covered, the thing is practically in the bag, and yet. A mouse is what one should be? A mouse is so inconspicuous, little and quiet? And you? According to regulations you are a louse, a roach, we are all roaches, through a whim of our creator we turned out to be ridiculously large roaches, and when has a roach ever wished to trade with a mouse? Jacob decides not to run, he prefers to creep, that makes it easier to keep the noises under control. If the searchlight swings into motion, he can always start to hurry. Halfway across he hears the sentry's voice, don't worry, it is not addressing him, the sentry says "Yes, sir!" Then he says "Yes, sir!" again, and then again, the only explanation is that he is on the phone. Maybe another sentry, who is also bored, called him up. But he wouldn't say "Yes, sir!" to him all the time, that's impossible. Maybe the boss with some kind of an order? Pretty irrelevant actually, but let's assume the most favorable circumstance, the sentry is on the line. What's the matter with you, have you gone mad, to scare a poor Jew out of his wits like that? 
("Yes, sir!") Didn't you see that the man was completely beside himself, his legs were shaking with fright! Don't ever let that happen again, do you hear? ("Yes, sir!") After the fourth "Yes, sir!" comes the corner, let him talk on until he is blue in the face, then Jacob will be at home--in not even ten minutes.

Jacob shares his room with Josef Piwowa and Nathan Rosenblatt. They have gotten to know each other right here, in this room, no one especially likes the other, crowded conditions and hunger cause friction, but one ought to say (for the sake of honesty), that their first encounter had already been quite formal.

Rosenblatt had died a full year before Jacob's lucky return, he had devoured a cat which had been careless enough to disregard the warnings along the barbed wire, and one day it lay in the courtyard, starved, Rosenblatt found it first, as I said, devoured it, and that's what he died of. Piwowa has been dead for only three months. His passing away was accompanied by certain mysterious circumstances, the only thing that is clear is that he was shot by a supervisor at the shoe factory where he was working. He got cocky, he said things about which even in normal times one had better keep quiet when talking to one's supervisor, and consequently the man shot him in anger. One theory has it that Piwowa didn't know how to control his temper, he had always been a hothead, and it had to come to this kind of an end some time or other. Others, however, claim that temper and emotions don't enter into this, they say that it was a matter of a very ordinary, though very cleverly arranged suicide. Be that as it may, Piwowa has been dead for three months and Rosenblatt for a full year, his bed went up the chimney 
last winter, Piwowa's is still waiting board by board in Jacob's basement for cold times to come. New shipments of roommates have not arrived yet, the supplies are used up, damned or blessed be all cats and supervisors, at any rate they didn't like each other. At least Rosenblatt keeps quiet when he is home, he sits in his bed with his eyes closed and prays, he is the last one to go to bed and the first one up, because his debates with God consume unlimited amounts of time. He didn't even give up this habit after his death, but as least he is quiet, sits silently with his eyes closed and only sneaks a look every once in a while.

Piwowa is quarrelsome. He was the last to be moved in, but behaves as though he had been the first. Rearranges everything, has to lie with his feet towards the window, one has to hide the bread rations from him. Let's just go ahead and say it, Piwowa used to work in the woods, as a poacher. His father had already been a poacher, he himself was an even better one, he had no children.

Well, Jacob comes home. It was a trying day, he experienced, went through, survived, trembled and heard a lot. Rejoice, brothers, go mad with joy, the Russians are twenty kilometers away from Bezanika, if that means anything to you. Open your eyes, Nathan Rosenblatt, stop quarrelling, Piwowa, the Russians are on their way, don't you get it, twenty kilometers from Bezanika! But Rosenblatt goes on praying, Piwowa keeps on lying with his feet to the window, let them lie there and argue and pray and be dead, Jacob is home and may the Russians hurry.

Let's chat a while.

Let's chat a while, the way one ought to in a proper story, don't 
deny me that little joy, without a bit of gossip everything is so miserably sad. Just a few words about questionable memories, a few words about the brevity of life, let's bake a quick cake with modest ingredients, eat just a little piece of it and then push the plate aside again, before we have no more appetite left for anything else.

I am alive, there is no doubt about that. I am alive and no one can force me to drink and to remember trees and Jacob and everything else. On the contrary, I've already been made an offer. I am supposed to treat myself to a few lovely days, after all, old chap, one only lives once. Wherever I look there is variety, new cheery worries with a little misfortune thrown in, women, that isn't over yet, replanted forests, well tended graves which at every occasion receive such quantities of fresh flowers, that it almost looks wastefur. I don't want to be immodest. Piwowa, whom I have never met, was immodest, one had to hide wild game and breadrations from him, but I am not Piwowa. Chan, my quarrelsome wife, once said to me: "You are wrong," that's how almost everything she said to me began, "a person is modest when he is content with what he has a right to. And no less."

If one looks at it that way, I should be very content, sometimes I even feel spoiled, people are friendly, helpful, trying very hard to look patient, I can't complain.

Sometimes I say: that was the whole story, thanks for listening, you don't have to prove anything to me.

"I have no intention to. But you should know that in 29. . ." "You don't have to prove a thing to me!" I say again. "Yes, I do. But when the war was over I had just turned. . ." 
"Kiss my ass," I say, get up and leave. After five steps I get mad at myself because I was so rude, so pointlessly insolent, and he didn't mean anything. But I don't turn around, I keep on going. I pay the waiter and as I leave I look back over my shoulder at the table and see him sitting there puzzled, what's gotten into me, and I shut the door behind me and don't want to explain it to him.

Or I am lying in bed with Elvira. Let me explain, I am forty-six, born in twenty-one. I am lying in bed with Elvira, we work in a factory, she has the fairest skin I ever saw. I think we'll get married some day. We are still breathing heavily, we've never talked about it, then she suddenly asks me: "Hey, is it true that you. .."

The devil knows who told her, I hear pity in her voice and go mad. I go in the bathroom, sit down on the tub and start singing, so that I won't do something I know I'll be sorry for five steps later. When I come back after half an hour she asks me, surprised, what was the matter with me all of a sudden, and I say, "Nothing" and give her a kiss and turn off the light and try to go to sleep.

The whole town is surrounded by greenery, the area is unique, the parks are well looked after, every tree invites me to memories, and I make liberal use of it. But whenever it looks me in the eyes, the tree, to see whether they light up, then I have to disappoint it, because it's not the right one.

Jacob tells it to Mischa.

He didn't really come to the freight yard with the intention of telling it to someone, but neither did he resolve to tell it to no one, 
he came to the yard with no intentions at all. He knew that it was going to be hard to keep the news to himself, hardly possible, after all what could be better, good news is there to be passed on. On the other hand, one knows how it is, the informant is held responsible for all consequences, in time information turns into promise, there is nothing you can do about that. At the opposite end of the city they'll be saying that the first Russians have already been spotted, three young ones and one looking like a Tartar, the old women will swear to it and the worried fathers. This one will say that he knows it from that one, and that one knows it from the other one, and someone in that whole succession knows that it comes from Jacob. From Jacob Heym? Inquiries will be made about him, everything concerning this most important of all matters will have to be checked out exactly: an honorable, reliable person, makes a solid impression, he is supposed to have owned a modest cafe somewhere around here. It looks as though one might have reason to rejoice.

Then days will go by, if God deems necessary, weeks, three hundred kilometers or five hundred are a long way away, and the looks Jacob gets won't be quite so friendly any more, not quite. On the other side of the street there'll be gossip, the old women will sin and wish him evil, the icecream he used to sell will by and by have been the worst in the whole town, even his famous raspberry ice cream, and his potato pancakes not quite kosher ever, that may well happen to him.

Jacob and Mischa are hauling crates onto a freight car.

Or let's take another possibility. Heym claims to have heard that the Russians are advancing, already four hundred kilometers from the 
town? Where does he claim to have heard that? That's just it, at the police station. At the police station!? A horrified look might follow, a slow nod of the head might answer, a nod confirming the suspicion. One wouldn't have thought that of nim, not of Heym, never, but that's how one can go wrong in judging people. And the ghetto might be richer by one alleged spy.

Anyway, Jacob came to the station without any firm intentions. It would be nice if they already knew it without him, if they had received him with the news, that would be the best. He would have rejoiced with them, he wouldn't have let on that there are three people who have already been informed, Rosenblatt, himself and Piwowa, he would have kept his mouth shut about that, rejoiced with them and at most asked after a few hours who the news came from. But as soon as Jacob got to work he saw that they didn't know yet, he could aiready tell by their backs. There was no such lucky coincidence, one couldn't really expect that, two lucky coincidences in such a short time only happen to Rockefeller on Sunday.

They are carrying crates to a freight car. Jacob isn't an especially sought-after loading partner, no one fights over him, giants grow slowly over a pancake griddle, and the crates are heavy. The yard is full of people nobody fights over, you have to look for the giants with a magnifying glass. The giants one does fight over, but you can't trade for them, they prefer to load together. Don't talk to me about camaraderie and such stuff, whoever talks like that doesn't understand anything about this place, not a thing. I myself am not one of the giants, I cursed and hated them like the plague whenever I had 
to load with a fellow like myself. But if I had been one of them, I would have done likewise, not a bit differently.

Jacob and Mischa are carrying a crate to the freight car.

Mischa is a tall chap of 25 with light blue eyes, which is very rare amongst us. He boxed once for Hakoah, only three fights, of which he lost two, and once his opponent was disqualified for a low blow. He was a middleweight, that is, he really was more of a light heavyweight, but his trainer advised him to train down a few pounds, since the competition in the light heavyweight class was too stiff. Mischa followed his advice, but it didn't help much, he didn't do that well in the middleweight class either, as his three fights prove. He already toyed with the idea of eating his way up to the heavyweight class, maybe it would have worked better there. At around 170 pounds the ghetto crossed his plans, and his weight has been going down ever since. Nevertheless he is still pretty strong, he really deserves a better partner than Jacob. Many people think that his good naturedness will cost him his head some day, but nobody tells him that, maybe he will find out for himself some day.

"Quit staring all around and watch where you are going. We'll both fall down yet," says Jacob. He is furious because the crate is so heavy despite Mischa, and mostly he is annoyed because he knows that Mischa will be the first one he will tell it to, the only question is how to begin.

They put the crate down at the edge of the freight car, Mischa is really not with it, they go back to the pile to get a new one. Jacob tries to follow Mischa's glance, Mischa is driving him crazy with his looking away, the station looks just as usual. 
"That car over there," says Mischa.

"What car?"

"On the second to last track. The one without a roof." Mischa is whispering, even though the closest guard is standing at least 20 meters away and is not even looking in their direction.

"What about it?" asks Jacob.

"There are potatoes in that car."

For the whole next loading trip Jacob grumbles, so there are potatoes in it, what's so special about that, potatoes aren't interesting until one has them, until one can boil them or eat them raw or make pancakes out of them, but not when they are lying on some car in a yard like this, the potatoes in that car over there are the most boring thing in the world. And even if there were pickled herring or roasted geese or millions of pots filled with cholent, Jacob talks and talks, Mischa must be distracted and involved in a conversation.

Only he is not listening, there will soon be a change of guards, they always make a little ceremony out of it, with their standing at attention, their sounding off, their guns over their shoulders, and that is the only time one could try it. Jacob's objections are not to be taken seriously, of course it is a risk, all right even a big risk, so what? Nobody claimed that the potatoes were practically eaten, every chance means a risk, does one really have to explain that to a businessman, if there wasn't any risk it wouldn't be a chance. Then it would be a sure thing, sure things are rare in life, risk and the hope of success are two sides of the same coin.

Jacob knows that there isn't much more time left, there is no talking normally to a chap in this kind of state. And then he sees 
the relief guards marching up in a column, and now he must say it to nim.

"Do you know where Bezanika is?"

"Just a second," says Mischa, all excited.

"I am asking if you know where Bezanika is?"

"No," says Mischa as his eyes follow the column on its last few meters.

"Bezanika is about 400 kilometers away from us." "Oh."

"The Russians are twenty kilometers from Bezanika!"

Mischa succeeds for a moment in taking his eyes off the marching soldiers, his rare eyes smile at Jacob, that's very nice of Heym, actually, and he says: "That is nice of you, Jacob."

Jacob almost falls over. Here one is sacrificing oneself, against all rules of care and precaution, which haven't been set up for nothing, and what does this snot nose do? He doesn't believe you. And you can't just walk off, you can't just leave him standing there in his stupidity and tell him to go to hell and walk away. You have to stay with him, to save your anger for another time, you can't even try to imagine what that other time would be. You have to beg for his good will, as if your own life depended on it, you have to prove your credibility even though you shouldn't need to, but he needs you to. And you have to do all that in a split second before they stand in front of each other and slap their guns on their shoulders and report to each other that there were no special occurrences.

"Aren't you happy?" asks Jacob. 
Mischa smiles at him kindly, "That's OK," he says in a voice which sounds a bit sad, but which is also supposed to show some recognition for Jacob's heart-warming care. And then he has to watch much more important things. The column approaches, they're already past the little brick house where the railroad workers and the guards have their quarters.

Mischa is shaking with excitement, and Jacob tries to make his words run faster than the soldiers. He tell his story in an abridged version, why didn't he start sooner, he tells of the man with the searchlight, of the hallway in the police station, of the door that opened towards the outside and hid him. The news coming out of the room, word for word, just in the way he had repeated it to himself a million times in the night, nothing added and nothing omitted. He leaves out his short imprisonment in the door crack, only the essentials, nothing about the man who took him to the officer on duty either, a mere walk-on in the story, only about the officer on duty himself, who must have been a human being and therefore a weak link in the chain of an otherwise logical sequence. He looked at his watch like a human being, and then he told Jacob to go home--like a human being.

And then Jacob sees with horror that nothing will hold Mischa back now except certainty, and the soldiers are already standing in front of each other, the enemy must be conquered when he expects it the least, for that is when his attention is weakest. Mischa crouches down and is ready to sprint, certainty and Russians are far from his mind, Jacob's last resort is to grab him and hold him by the leg. They both fall down, Jacob sees the hatred in Mischa's eyes, he ruined his chance or at 
least he is trying to. Mischa frees himself, nothing can hold him back now, he pushes Jacob aside.

"I have a radio!" says Jacob.

It wasn't the guards that fired. They haven't seen a thing yet, they are busy with their changing game, Jacob fired and hit the target. A lucky shot from the hip without even having aimed properly, but he hit the target anyway. Mischa sits there motionless, the Russians are four hundres kilometers away from us, near some Bezanika or other, and Jacob has a radio. They sit on the ground looking at each other, there never was a freight car with potatoes, no one was ever waiting for the changing of the guard, all of a sudden tomorrow is another day. It is still true that chance of success and risk are two sides of the same coin, but now one must be crazy to overlook the fact that there has to be a sound relation between them.

They sit there a little longer, Mischa smiles happily with his goy eyes, look what Jacob has done to him. Jacob gets up, one can't sit forever, he is even madder than a while ago. He has been forced to dream up irresponsible claims, that unsuspecting idiot over there forced him with his ridiculous lack of trust, just because he suddenly got hungry for potatoes. He will still tell him the truth, not right away but today still, whether this freight car is around tomorrow or not. In one hour, at most in an hour, maybe even sooner he will tell him the truth, let him bask in his joy for a few more carefree minutes, though he doesn't deserve it. Soon he won't be able to live without that joy any longer, then Jacob will tell him the truth, and then he will have to believe the story of the police station, that part doesn't change anything about the Russians, he will have to believe it. 
"Pull yourself together and get up. And above all shut up. You know what that means, a radio in the ghetto. Not a soul must find out about it."

Mischa couldn't care less about what it means, a radio in the ghetto. Let a thousand regulations prohibit it under penalty of death, let them, does that still matter now that tomorrow is suddenly another day?

"Oh, Jacob. . ."

The leader of the guards sees a lanky lad sitting idly on the ground, just sitting there not even collapsed, just leaning back on his hands, staring into the sky. He pulls his jacket down straight and starts on his way, the little fellow.

"Watch out!" calls Jacob nodding his head in the direction from where danger is strutting forth with dignity.

Mischa come to, back to earth, he gets up, knows what is about to happen, but can't keep his face from continuing to rejoice. He busies himself with the crates, is about to put one down, when the leader slaps him from the side. Mischa turns towards him, the leader is a head shorter than he, and it is not easy for him to slap upward into Mischa's face. It almost looks a little funny, not the right thing for German newsreels, but rather like a joke from the era of the silent film, when the little cop Charlie tries to kayo the giant with the bushy eyebrows, and he struggles and struggles and the big fellow doesn't even notice. Everyone knows that Mischa could lift him up and tear him to bits. If he only wanted to. The leader slaps some more, his hands must be getting sore, he yells some kind of stuff that interests no one and only 
quits when a thin stream of blood runs from the corner of Mischa's mouth. Then he pulls his jacket down again, notices a bit late that in all this excitement he has lost his cap, picks it up, puts it on his head, goes back to his men, the new guard walking behind him.

Mischa wipes the blood off his mouth with his sleeve, winks at Jacob and reaches for a crate.

"Come on, let's go," he says.

They lift up the crate, Jacob's anger wells up while he is hauling, almost pulling his teeth apart. He isn't superstitious, and there is no higher power, but in some strange way, maybe just because it was a bit funny, Mischa deserved the slaps, he thinks. "Oh, Jacob. . ."

We know what is going to happen. We have a modest amount of experience with how stories sometimes have a way of turning out, we have some imagination, and that is why we know what will happen. Mischa won't be able to keep his mouth shut. Promise or no promise, he won't mean any harm by breaking the silence or not even trying not to, it won't be out of nastiness to get Jacob into trouble, it will be out of sheer joy, nothing else. Stop taking your lives, soon you'll need them again. Stop having no hope, the days of our misery are numbered. Try hard to survive, you have plenty of experience, you all know the millions of tricks by which one forces death to go empty-handed, you have managed to this day. Just try to survive the last four hundred kilometers, then survival will stop and life will begin.

Those are the reasons, Mischa won't be able to keep his mouth shut, they'll ask him for his sources, he will surrender them, what does 
it matter. Soon even the kids in the ghetto will know the big secret, in strictest confidence of course, they will find out when in their joy their parents forget to whisper. People will come to Jacob, to the radio owner Heym wanting to know if there are any news, they will come and their eyes will look unlike any eyes Jacob has ever seen. And just what will he tell them?

Half a day has gone by, the big crates have been stored in the freight cars, then come the smaller ones, the kind that one man can carry by himself, and now Jacob has lost sight of Mischa. That is, not really lost sight, they see each other every few minutes, but always with a few meters between them, only in passing by, with their backs under a load or on their way to a new haul. The opportunity for an explanation has not come up, one can't just take him aside and say: this is how it really was. Each time they see each other, Mischa winks at him or smiles or makes a face or waves secretly, whether with a crate or without, it hardly makes any difference to him, each time something confidential, you and I know what's cooking. Once Jacob forgets himself and winks back, but he remembers right away, that would be going too far, that would block the path to future opportunity. But it's beyond his control, each time his anger is becoming weaker, the boy is right to be happy, how could he help but be happy after all that has happened.

It's a blue day, just right for the party. The guard by the wooden barracks is sitting on some bricks, he has taken off his gun and put it next to him, he is leaning his head against the wall, closing his eyes and sunning himself. He is smiling, one might almost feel sorry for him. 
Jacob walks past him and watches him, he walks very slowly, studying the face with its closed eyes, he memorizes that smile, the large Adam's apple, the thick golden ring on the guard's baby finger. Jacob walks on and discovers, as he told me, that he has changed. His senses are suddenly much keener, just from one day to the next he is beginning to observe. His indifferent despair did not survive last night's excitement, there is nothing left of the dullness, it is now as though one had to commit everything exactly to memory, in order to be able to report about it afterwards. Afterwards.

Jacob dreams up an innocent little game. On his way to the freight car or on his way back to the crates he always walks right close to the dozing guard. Almost climbs over his outstretched legs, that close, each time blocking the sunshine for a short moment. The guard, of course, doesn't notice, doesn't even open his eyes, even though he is not sleeping, only moves his head a bit once or his mouth twitches with annoyance, as it seems to Jacob, or he doesn't do anything at all. But at every passing he loses a bit of sunshine. Jacob plays his little game until another stack of crates is to be loaded. The guard is no longer lying in his path, one would have to make a detour, and that again would mean less fun and too big a risk. Jacob sees with satisfaction that a few small clouds are carrying on his prank. Then it is noon.

Out of the stone house steps a man in railroad workers uniform, always the same one since we've been working here. He has one stiff leg, which at every step makes little sounds like a pebble falling in the water, in other words, a wooden leg. We call him the whistle, not contemptuously, because we know nothing about his human or professional 
qualities. The only thing we have against him is that he is a German, which, looked at objectively, shouldn't be a reason for a negative judgement, but that's how unfair one can get in bad times. As soon as he comes out of the house he pulls a whistle out of his breast pocket, which is fastened to his buttonhole by a black cord, and blows it with considerable strength as a signal that it is now noon. This is the only sound we have ever heard from him, aside from the gurgling of his wooden leg, and that's why we call him the whistle. Maybe he is a mute.

We all stand in a line, very disciplined and without any pushing. They've taught us that under the threat of no food. It has to look as though we weren't at all hungry just then, not food again, you've just got warmed up working and already you are interrupted by one of those many meals. Well anyway, we all stand in a line without hurrying, you turn around and align yourself until everyone stands in an imaginary perfectly straight line, by stretching out one arm you check your distance to the man in front of you, correct your position by a few centimeters, that will give the impression that one is among civilized people here. Spoons out of the pocket, into the left hand, exactly at the seam of the left pantleg. Then the cart comes around the corner of the barracks, the stack of metal bowls next to the two green army kettles. The cart stops at the head of the voracious snake-line. The first man steps up, opens the kettle, burning his fingers every time, and begins ladling it out. The whistle stands there silently, eyes fixed, to see that it is done fairly.

On this blue day I am the ladler. I dont't know anything, I am always the last one to know, the sun is getting to me, I am furious. 
I am mad about the extra work, my burned fingers are hurting, I'll be the last one to eat. I slap the soup ladle into their bowls, they trudge off with it, I discover nothing unusual in any of their faces, but then I am not looking for anything either. I don't even notice whom I happen to be giving the soup to, all I see is bowls.

Jacob has taken his food, he looks around for Mischa who had been way ahead of him in line. Noon would be such a convenient time, an undisturbed tete a tete, a small correction which won't change a thing in the actual state of affairs. Mischa is nowhere to be seen, the yard is big, people disappear with their bowls. The break is too short for a thorough search. Jacob sits down on a crate and eats the hot soup. He too is only human, his thoughts stray far away from his bowl, what will happen and how much longer, and what afterwards, the sun is pouring down and no one is giving him shade. Then Kowalski comes.

Kowalski comes.

"This spot is still free isn't it?" asks Kowalski.

He sits down next to Jacob and starts spooning up his soup. Kowalski is great. He thinks he is so clever and unflappable and yet his face can't hide anything, it is a talkative face. If one knows him a little bit one can tell exactly what is the matter with him, before he has even opened his mouth. His words are always just a confirmation of old suspicions, even if one only knows him a little bit, and Jacob knows him since the time they went to school together. They lost sight of each other a bit here, in these dark times, the reason for that is easily told. Neither one of them is a giant, a crate doesn't get any lighter when there is an old friend on the other side, that's how it 
came about. And otherwise there are practically no opportunities. One either has contact with one another or one doesn't. One hardly does, and now Kowalski comes along with his bowl, says "this spot is still free isn't it?", sits down next to Jacob and eats.

Kowalski was Jacob's most frequent customer. Not his best, his most frequent one. Every single day around seven the bell jingled, and who would come in but Kowalski, sit down in his place, and eat potato pancakes until you felt faint just watching him. He'd never let it go at less than four or five, and afterwards he'd usually top it off with a little drink, in secret, since Jacob had no liquor license. Any restaurant owner would have marvelled at such a customer, but not Jacob, for Kowalski never paid, not a penny, not even once. Common school days were not the reason for Jacob's generosity, what kind of a reason would that be, in fact it wasn't generosity at all. In a weak moment, on an evening of drinking, they came to an agreement. Kowalski's barber shop was only a few houses away, they met almost every day anyway, and the agreement seemed advantageous to both of them. You for free at my place, I for free at yours. Later on they both regretted it, but an agreement is an agreement, and after all, one man alone can't ruin another. Though they both tried. At first potato pancakes were Kowalski's favorite dish, and that must have been the reason for the suggestion, but soon things changed. After a while they were coming out of his ears, he only ate those four because Jacob would silently put them in front of him, the little drink afterwards was what mattered to him now. 
On the other end Jacob suffered initially from the unalterable fact that one can eat potato pancakes daily, but not have one's hair cut every day. After careful thought, he hit upon shaving. He even sacrificed a sparsely growing beard, though with a bad conscience. His greatest time were summers, luckily for him Kowalski's stomach couldn't handle ice cream and so temporarily he became sole beneficiary of their agreement. But in time his ambition disappeared, there were other more important worries, he let his beard grow back, and the whole thing petered out, except for the occasional flare-up.

But these are old stories, Kowalski is sitting next to him spooning up his soup, in silence for who knows how much longer, the red spots on his gaunt cheeks tell of one suppressed question. Jacob stares into his empty bowl, thinks: maybe it's a coincidence, there are strange coincidences. "How are things?" would sound idiotic, he thinks. He carefully licks his spoon clean, puts it in his pocket, there is no good reason to get up yet, the break is a few minutes longer yet. The last ones in line are just getting their food. He puts the bowl down, leans back on his hands, closes his eyes, his head turned upwards, to be the guard for a few minutes and to enjoy the sun!

Kowalski stops spooning, Jacob can hear through his closed eyes that his bowl isn't empty, he hasn't scratched the bottom yet. So Jacob hears that Kowalski is looking at him, it won't be long now, but for the right beginning.

"Any news?" asks Kowalski casually.

When Jacob looks at him he is spooning up his soup again, his 
real thoughts still written on his cheeks, but his innocent eyes right in the soup bow1. It sounds just as though you were stepping into his barber shop, you sit down on the only chair in front of the only mirror, he is shaking the last customer's black hairs off the apron, ties it around you, much too tightly, as usual. "Any news?" Mundek's son won his first case, he will make his way by the looks of things, but that's nothing new, Huebscher already told about that yesterday. But what you probably don't know yet is that Kwart's wife left him, nobody knows where she took off to, but then no reasonable human being can get along with him. It all sounds so familiar that Jacob almost feels like saying: "Don't cut them so short in back as you did last time."

"We11, what is it?" asks Kowalski, while his eyes are about to drown in the soup.

"What news?" says Jacob. "Why do you happen to be asking me that?" Kowalski reveals his real face to Jacob, his whole foxlike face that can't hide anything, he turns it towards Jacob with an expression of gentle reproach, with a little understanding for Jacob's caution and with an indication that this caution is uncalled for in this particular case.

"Jacob!. . .Aren't we old friends?"

"What does that have to do with it?" says Jacob. He is not sure whether he'll manage to sound convincing in playing dumb, after all, Kowalski has known him for a long time. And he could well feel that it actually doesn't matter much whether he manages or not, when Kowalski knows something, nothing will fool him. When Kowalski knows something he won't leave you alone, he will torture you until he draws blood. 
Kowalski moves a little closer, leaves his spoon floating in the soup, grabs Jacob by the arm with his free hand, he won't get away now.

"All right then, let's talk openly. . ." Letting his voice drop down to the volume appropriate for secrets, he whispers: "Is that true about the Russians?"

His tone worries Jacob. Not the whispering, one whispers at all kinds of occasions, that needn't scare anyone. He worries about the seriousness, he realizes that this won't be taken lightly, he worries about the trembling in Kowalski's voice. There is a note of expectation which will not tolerate any teasing, there is a demand for certainty in it, a man is asking, and all this man wants is an answer to this one question, he must have it and nothing else, once and for all. And yet Jacob makes one last pointless attempt: "About what Russians?"

"About what Russians! Do you have to do this to me, Jacob? Have I ever done anything mean to you? Think about it, Jacob, think about who is sitting next to you. The whole world knows that you have a radio, and to me, his only and his best friend, he won't tell a thing!" "The whole world knows about it?"

Kowalski takes it back. "Well not exactly the whole world, but a few probably do. Did someone tell me or am I clairvoyant?"

In Jacob's mind one nuisance replaces another. Kowalski is being pushed into the background by Mischa, this blabbermouth is bringing him into an impossible situation. All of a sudden it has become unnecessary to take Mischa aside for a correction, completely superfluous, the fire can't be stopped now. Who knows how many would have to be taken aside already. And even if one took the trouble in every single case, if one 
tried to explain with angelic patience to every single man the idiotic way in which this glorious news had blown into the ghetto and right into their ears, what could they possibly do but not believe him? With all due consideration and all the understanding for his situation? Or does anyone really seriously believe Kowalski could afford to let himself be brushed off with a story that doesn't hold water?

"Well, what is it?"

"It's true about the Russians," says Jacob. "And now leave me alone."

"They are 20 kilometers from Bezanika?"

Jacob rolls his eyes and says: "Yes!"

He gets up, that's how they spoil your fun, and actually one has just as much right to it as they have. A kingdom for Kowalski's having been discovered by the sentry on the Kurlandischen or some other person. Why was he hanging around there yesterday evening anyway? All respectable citizens are lying in their beds, but he has to roam the streets at odd hours of the night, because the ceiling is falling in on him, or because Piwowa and Rosenblatt are unbearable again, because a little stroll after a day's work has such a strange flavor of normal times. A little stroll in a town that one has known ever since one was propped up in a baby carriage with a pillow in one's back. The houses tell you almost forgotten trivia, that's where you fell down and twisted your left ankle one time, at that corner you finally once told Gideon the truth to his face, in that yard there was a fire right in the middle of winter. Such a good old flavor of normal times, that's what he was after, though he didn't feel it for long, and now this. 
"Will you at least keep quiet?"

"You know me," says Kowalski. He wants to be left alone for now, the break is short, one has enough worries of one's own as it is, and now suddenly this new stuff coming up.

Jacob picks his bowl off the ground and leaves. He takes Kowalksi's face with him, bent to one side, no war anywhere in sight, his eyes fixed on a distant point that no one else is able to see. He still hears Kowalski's lips whispering lovingly: "The Russians. . ." Then he has reached the cart, puts his bowl with the others, looks back at Kowalski, who has started to fish his spoon out of his soup. The whistle blows, even Kowalski hears it, a little tower of bowls is quickly build. It seems to Jacob that everyone is looking at him strangely, even differently from yesterday, somehow the secret is in their glances. Maybe it's an illusion, surely it is, they can't possible all know it already, but one or another must have been present.

I would like, since it is not too late yet, to waste a few words about my sources, before a suspicion arises here and there. My most important authority is Jacob, most of what I heard from him can be found here somewhere, I can vouch for that. But I say most, not all; with good reasons do I say most, and this time it's not because of my bad memory. After all, I am telling this story, not he, Jacob is dead, and besides I am not telling his story, but a story.

He spoke to me, but I am talking to you, that makes a big difference, because I was there. He tried to explain to me how one thing led to another and that he couldn't have done otherwise, but I 
want to tell that he was a hero. He never uttered three sentences without mentioning his fear, but I want to tell of his courage. Of these trees, for example, of these trees that don't exist and that I am looking for, about which I would like to stop thinking but can't and my eyes start clouding over, of them he knew nothing, that is my very own business. I can't get it all together now, but there are other things that he knew nothing of, where he might have asked me what made me think of them, and yet I believe that they are part of it. I would like to tell him why I think that, I am accountable to him, I think he would agree with me.

There are a few things that I know from Mischa, but then there is a big gap for which no witnesses can be found. I say to myself, it must have been this way or that way, or I say to myself it would be best if it had been this way or that way, and then I tell it and pretend that it is part of it. And it is part of it, it isn't my fault that the witnesses who could confirm it are nowhere to be found.

The plausibility is not essential for me, it is implausible that I of all people am still alive. Much more important is that I think it could or should have happened this way, and that has nothing to do with plausibility, I can vouch for that too.

It wasn't Mischa's worst idea to strike up a conversation with Rosa during the food stamp handout, to ask her, having gathered all his courage, if they didn't have the same stretch to walk at least for a little while, and fortunately she agreed. At first it was just her face that loosened up his tongue, after all how many girls have been accosted 
for their shiny eyes, but then one thing led to another, and today, about one year later, he loves her totally, just as she is. The first steps were embarrassingly silent, his head felt hollowed out. He didn't get the least bit of support from her, not even an encouraging glance, she just looked shyly in front of her and was probably waiting for something important to happen. But nothing happened, nothing until they were at her front door, her mother was already standing by the window worrying where her only daughter might be all this time. Rosa said goodbye quickly, her eyes lowered, but she must have just heard where and in what exact spot he was going to wait for her the next day.

In any event, she kept the date. That was a load off Mischa's mind, he put his hand in his pocket and gave her his first present. It was a little book of songs and poems, he already knew them all by heart, it was the only book he happened to own. Actually he had wanted to give her an onion, one with a bluish skin if possible, he had taken the whole thing with Rosa very seriously right from the beginning, but that had been unrealistic, despite all his efforts he couldn't possibly manage to hunt one up in such a short time. At first she was a little coy about whether she should accept the present, as inexperienced girls of ten are, but then of course she took the book after all and told him that she was very happy about it. Then he finally introduced himself, yesterday he hadn't had a chance to in all the excitement, and then he heard her name for the first time, Rosa Frankfurter.

"Frankfurter?" he asked. "Are you by any chance related to the famous actor Frankfurter?"

That was, as could later be verified through programs from the municipal theater, quite an exaggeration, the actor Frankfurter never 
made it to more than middling roles. But Mischa had not meant it sarcastically, he had never seen Frankfurter act, he has only once been to the theater, he had just heard or read about him. And Rosa hadn't taken it that way either, she admitted, blushing, that that really is the case, that the actor Frankfurter is her father. Then they chatted a bit about theater, of which he knew practically nothing, but later on he managed with much ingenuity to gradually bring the conversation around to boxing, about which she again knew nothing. Thus they got on famously, and on that very evening she did not object to Mischa's first kiss on her silky hair.

When Mischa comes in Felix Frankfurter is sitting at the table with his daughter over a game of checkers. He is a tall man, tall and thin, Mischa described his appearance to me with much loving care. An impressive bulk of former times has wrinkled up Frankfurter's skin, which is emphasized even more by the fact that the clothes he wears also stem from considerably fatter days. Photographs prove that years ago man and skin used to form a well balanced whole, there's a big album full of pictures to which Frankfurter treated Mischa on his very first visit. For he couldn't possibly resign himself to this unflattering impression of which he was so keenly aware. With a scarf around his neck, looking arty and casual, one end hanging down the front, the other down his back, in his mouth a pipe, a Meerschaum, which has long since forgotten what tobacco tastes like.

He is sitting at the table with his daughter, the match is hopeless for Rosa. Frau Frankfurter is sitting with them, she is not 
paying any attention to the game, she is mending one of her husband's shirts, taking it in even more, and possibly dreaming of a time of quiet happiness. When Mischa comes in, Rosa has just gotten upset about the match with her father being so boring, because he thinks for ever about each move, and he has just tried to explain to her that it is smarter to win one game in two hours than to lose five.

"But what are you still racking your brains about now?" she has just asked. "You are winning anyhow."

"I am not winning anyhow," he has said, "but only because I think about it for so long."

She waved her hand at him in anger, any fun in the game was out of the question now, it was merely out of obedience that she didn't push the checkers off the board, and because Mischa wasn't there yet, but then there is a knock at the door. She quickly runs to open it and Mischa comes in. They say hello, Frankfurter asks Mischa to have a seat, Mischa sits down. Rosa quickly clears away the checkers and the board before Mischa can take over her lost game. He has often sat down in her place, looked for a way out, given up in the end and asked for a return match. Frankfurter would then give him the chance, they would both sit and ponder and all of a sudden it would be so late that Mischa had to go before Rosa had had any time with him.

"You were playing?" asks Mischa. "Who won today?"

"Who do you think," says Rosa, and it sounds like a reproach.

Frankfurter puffs on his Meerschaum pipe, content as can be and winks at Mischa. "She plays faster than she thinks. But I bet you've already noticed that on other occasions, right?" 
Mischa ignores the little joke, he is not coming empty handed today, he is just thinking about how to break the news most effectively, for Frankfurter likes nothing better than a story with a point at the end. Whenever he talks about theater, where, if one is to believe him, the craziest things happened, there isn't a step or a glance that doesn't have some special relevance. Somebody fell or made a fool of himself or ruined the performance or didn't understand why the others were laughing. If it wasn't like that, Frankfurter probably thinks it needn't be told at all.

"What can one offer a guest these days?" Frankfurter says to his quiet wife. And then to Mischa: "What can one offer a guest aside from one's daughter?"

He smiles, a witty remark, then he puffs on his pipe again. Anyone can puff on an empty pipe, it's child's play, but not like Frankfurter. He acts out the enjoyment, the cozy richness of smoke, if you don't look closely you might almost feel tempted to wave the clouds away.

There is silence for a few thoughts, in a minute Frankfurter will tell an anecdote, one of those stories of his, after which he is always so overjoyed that he starts slapping his thighs; like the one, for example, where William Tell doffed his hat to the hat on the pole right at the beginning of the performance, just for the sake of some silly bet, or the one about the actor Strelizki, who is said to have been a divine Othello otherwise, but whose dentures fell out of his mouth just as he was bending over Desdemona, in order to strangle her. Rosa lays her fingers on Mischa's hands, her mother is still taking in the shirt, Frankfurter is rubbing his knees, maybe he is not in the mood today and 
yet Mischa is coming with such good news, he is only trying to work out the best way of telling it, just like a move in checkers.

"Have you heard the latest news yet?" Rosa suddenly asks him.

Mischa looks from one to the other in surprise, he stops searching and wonders why Frau Frankfurter isn't even looking up from her shirt. They already know it and he didn't notice until now that they already know, he is surprised that everything in the room still looks like on his last visit. He is surprised at how fast it travels, only this morning did he hear it from Jacob and now it is already here at the Frankfurter's, by way of how many stations, but the strangest thing is that Rosa hasn't mentioned it until now. She couldn't have forgotten about it and just remembered again, impossible, something is fishy, maybe they have their reasons for not believing it.

"You already know about it?"

"They were telling it at work a while ago," says Rosa.

"And you are not happy about it?"

"Happy?" says Frankfurter (he says it with theatrical emphasis). "We are supposed to be happy? What are we supposed to be happy about, my boy? Some time ago they could have been happy about it, called all their relatives together and gotten drunk, but today there are a few small details that have changed. I think this whole thing is a terrible shame, almost a misfortune for those people, and you are asking why I am not happy?"

Mischa realizes right away that they are talking about something completely different, that is the only explanation for this glooom, unless Frankfurter has lost his mind and doesn't know what he is talking about any more. 
"It will be hard to raise that child," says Frau Frankfurter in between two stitches.

The first clue, new surprise in Mischa's eyes, they're talking about some child, news reports don't travel that fast after all. It looks as though two insane people have brought a child into this world, without having heard the news, in normal ghetto times that is certainly something one talks about. But since yesterday times are no longer normal, a different wind is blowing, we can tell you a few things that will make you forget child and husband and wife and eating and drinking, ever since yesterday tomorrow is another day.

Now Rosa is surprised, first she is surprised and then she smiles about Mischa's face.

"You don't really know it after all," she says. "But that's how he is. He can't stand it when other people know more than he. He is always pretending to be Mr. Know-It-A1l, but he doesn't have a clue about anything. In the second district a baby was born, on Vitebsk Street. At first there were twins, but one died right after birth. Last night. When it's all over they want to register the boy under the name of Abraham."

"When it's all over," says Frankfurter. He puts his pipe on the table, gets up, walks back and forth in the room, his head bowed and his hands on his back. His disapproving glances meet Mischa, who surely isn't smirking. They take it so lightly, Rosa too, maybe they are too young to understand, they talk about future times like about some weekend that will certainly come, one drives out into the country with the whole family and a basket of food, whether it happens to be raining 
or not. "When it's all over the child won't be alive any more and the parents won't be alive any more. We all won't be alive any more, it'll be all over then."

Frankfurter has arrived, his walk is finished, and he sits down again.

"I prefer David," says Frau Frankfurter quietly. "Dovid1. . .Do you remember that was the name of Annette's son. Abraham sounds so old, not like a child. And really the name only matters in children. Later on when they are big it's not so important any more."

Rosa likes Jan or Roman better, she thinks one ought to start moving away from the traditional names, when one doesn't have to wear the star any longer then there should be other names too. Frankfurter shakes his head over women's talk, and Mischa suddenly wishes he hadn't come until now, just burst into the house with the news as it is. Because if he starts talking about it now they'll feel just as he did a while ago, they'll think why hasn't he said it before, he couldn't have forgotten about it. He sits and sits, they are talking themselves more and more deeply into their gloom, either he doesn't say it until tomorrow and acts as though it was the latest news or he makes up a story that explains why only now and not right when the door was opened. He decides in favor of today, one more story with a little point to it for Frankfurter, he stands up, acts coy, he isn't quite sure himself whether it's an act or real, he looks embarrassed at Frankfurter who is already wondering about all this preparation and then he asks him in due formality for the hand of his daughter. 
Rosa discovers something on her fingernail which engrosses her totally, something so important that her face turns red and begins to glow, they had never spoken one word about it before, which would really have been the proper way. Frau Frankfurter hunches deeper over the shirt which is not nearly small enough yet, the collar is the hardest, because one is fussy about an exact fit. Mischa is enjoying his bright idea, successful or not, Frankfurter is baffled and about to say something. It's his turn to speak, a polite question deserves an answer, misguided as this question is or at this point appears to be, he will build a bridge to the big news item and that will also be the explanation as to why not until now. That is Mischa's plan, conceived in the greatest hurry and not all that bad, Felix Frankfurter will build a bridge, it's his turn, everyone is waiting for an answer.

Well, utter amazement as far as Frankfurter is concerned, disbelief in his eyes, he just took a puff on his pipe and forgot to blow out the smoke. This father, who wouldn't give his only daughter to anyone but Mischa--he already loves him like his own son--this man of sober reality whom nothing can fool, is dumbfounded.

"He's gone mad," he whispers, "his mind is troubled, it's these goddamned times where normal wishes sound like monstrosities. Why don't you say something to all this!"

But Frau Frankfurter says nothing to all this, she lets a few tears drip quietly onto the shirt, what can she say, all important matters have so far been decided by her husband only.

Frankfurter takes up his walk again, inner agitation, and Mischa looks hopeful, as though there could only be one answer. "Take her and be happy together." 
"We are in the ghetto, Mischa, do you know that? We can't do as we please because they do with us as they please. Should I ask you what kind of security you have to offer, because she is my only daughter? Should I ask you where you two intend to take up residence? Should I tell you what kind of a dowry Rosa will get from me? Surely that interests you? Or should I give you a few tips on how to have a happy marriage and then go to the rabbi and ask him when the chassene is most convenient for him?...You'd be better off racking your brains about where you are going to hide when they come to get you."

Mischa remains confidently silent, that wasn't any kind of an answer yet at all.

"Just listen to that! His ship has gone down, he is swimming right in the ocean, no human being anywhere in sight who might help him. And he wonders whether he'd rather go to a concert or to the opera that evening!"

His arms hang limply, everything that can be said Frnkfurter has said, even a little allegory offered at the end, he needn't be any more explicit than that.

But on Mischa he has made no impression. On the contrary, everything happened according to wish. No help anywhere in sight, that's the kind of sentence Mischa has been waiting for, soon you'll know how things really stand. It does make sense to speak of the future, Mischa is no idiot, of course he knows where we are, of course he knows that he can't get married until, and that's just the point, until the Russians come. 
Mischa to me: "Then I told them quite plainly (literally: quite plainly) that the Russians are 20 kilometers from Bezanika. You understand, it wasn't just an announcement, it was an argument as well. I imagined that they would start shouting with joy, one doesn't hear this kind of thing every day. But Rosa didn't put her arms around me, she didn't dream of it, she gave the old man an almost scared look and he just looked at me, so that I was beginning to get worried. At first I thought maybe they need a little time to get it, the way the old man looked at me, but then I realized that it isn't time they need but certainty. That's how I had felt too, remember, I too had thought that Jacob was just trying to take my mind off the potato freight car, I thought that until he told me the whole truth and how he knew about it. News like that without a source isn't worth anything, it's just a rumor. So I am about to open my mouth and take their doubts away but then I decided to wait. Let them ask, I thought, if you are the one to force it out of somebody it'll go into your head more easily than if he just tells it to you all at once. And that's exactly what happened.

Endless silence, as I said, the needle is stuck halfway through one stitch, Rosa's hot breath, Frankfurter's eyes, Mischa is standing in the spotlight, the audience hanging on his every word.

"Do you know what you are saying?" says Frankfurter. "That's nothing to joke about."

"You don't have to tell me that," says Mischa. "I know it from Heym."

"From Jacob Heym?"

"Yes." 
"And what about him? How does he know that?"

Mischa smiles feebly, acts embarrassed, shrugs his shoulders wretchedly, which doesn't fool anyone, somewhere a promise has been made. The fact that he isn't going to keep it is another matter, but the promise has been made and one would at least like to be urged to break it, one wants to have done one's utmost, you wouldn't have been able to do anything else in my position either.

"I said, how does he know that?"

"I promised him not to tell anyone," says Mischa, really already prepared to do it anyway, but not obviously enough, in any case not obviously enough for Frankfurter. This isn't the time to pay attention to nuances of tone, Frankfurter takes two, three quick steps forward and gives Mischa a slap in the face, a cross between a staged and a real one, but more of a real one, there is some outrage in it, we aren't just standing around here talking to pass the time.

Mischa, of course, is somewhat taken aback, he didn't need that much urging, but he mustn't be hurt now, after all he did have to be urged in some way. He can't just sit down with a blank expression, arms crossed over his chest and wait for an apology, he might have to wait forever. He can, and he does, dispel all doubts, now is the time, his plan worked, no one will ask: why not until now?

"Jacob Heym has a radio."

A little more silence, a few glances are exchanged, the shirt that is still too large sinks to the floor unnoticed, surely one can believe it when one's own son-in-law says it. At last Rosa puts her arms around him, he's been waiting for long enough, over her shoulders he sees 
Frankfurter sitting down exhausted, putting his hands on his wrinkled face. No conversation will start now, there is nothing to say, Rosa pulls his ear to her mouth and whispers. He doesn't understand, the old man still has his hands in front of his face, and Mischa looks at her questioningly.

"Come on, let's go to your place," Rosa whispers again.

A wonderful idea, she is taking the words out of Mischa's mouth, today there is no end of good ideas. They leave more quietly than necessary, the door clicks shut, no one hears it, it's already getting dangerously dark outside.

Then Frankfurter is alone with his family, without any witnesses. All I know is how it ended, the final result, nothing in between, but I can only imagine it this way or roughly like it.

The wife finally gets up at some point. She wipes off her tears, not the ones from the marriage proposal any more, or else she doesn't wipe them off at all, she goes to her husband, quietly, as though she didn't want to disturb him. She stands behind him, puts her hands on his shoulders, she brings her face close to his, which is still covered by his hands, and waits. Nothing happens, even when his arms drop down, nothing, he stares at the wall in front, and she nudges him gently. She is looking for something in his eyes and can't find it.

"Felix," she may have said after a while, "aren't you happy? Bezanika isn't so terribly far. If they made it that $f a r$, they'll surely get to us." 
Or she may have said: "Think of it, Felix, if that's true! My head is spinning, just think of it! Not much longer, and everything will be like it was. You'll be able to act again, on a real stage, I am sure our theater will be reopened, I'll come and pick you up after every performance, I'll wait for you next to the billboard by the doorman's box. Just think of it, Felix!"

He doesn't answer. He gets up from under her hands and walks to the closet. Maybe he looks like a man who has made an important decision and doesn't want to lose any more time before carrying it out.

Frankfurter opens the closet, takes out a cup or a little box and finds the key in it.

"What do you want in the basement?" she asks.

He weighs the key in his hand, as if there was something more to be considered, maybe the question of the right moment, but the sooner the better, that's all that matters. Maybe he already tells her what he plans to do, still in the room he lets her in on it, but that's unlikely, he has never much asked for her opinion. Besides, it's completely unimportant when he tells her, that won't change anything, the key is already in his pocket. Let's assume he locks the closet without a word, goes to the door, turns around to face her and says only: "Come."

They go into the basement.

Poor folks' homes, into which one wouldn't have set foot before, the wooden steps are worn down, they creak like crazy, but he walks close to the wall on tiptoes. She follows him all worried, very quietly too and on tiptoes, she doesn't know why, just because he does. She has 
aiways followed him without asking, she often could only guess at what was to be done, it wasn't always good that way.

"Won't you tell me now what we are doing here?"

"Shhh."

They walk along the narrow basement hallway, one can already walk normally here, the second to last section to the right is theirs. Frankfurter unlocks the lock, opens the wire door with the iron frame, which is still there since it won't burn. He goes in, she follows him hesitantly, he closes the see-through door behind her and there they are.

Frankfurter is a careful man, he looks for a piece of burlap or a sack with holes, which he tears, or, if there is no sack, he takes off his jacket and hangs it in front of the door, just in case. I imagine him putting his fingers to his mouth, closing his eyes and listening, but nothing can be heard. Then he starts rummaging around in the little pile that fills one corner of the room, a little pile of useless stuff, a little heap of memories.

At that time, when the news came, they sat together for two days deciding what to take along, aside from the things that were prohibited, of course. The situation was, without doubt, very serious, they hadn't expected it to be paradise, but no one knew anything precise. Frau Frankfurter's thoughts were practical, too practical for him, she thought of bed linen and dishes and clothes to wear, but he wouldn't part with many things she considered superfluous. With the drum, on which he had announced the arrival of the Spanish heir to the throne in an extremely successful performance, and with Rosa's ballet shoes, when 
she was five years old and which are still practically new today, with the album with the carefully pasted-in reviews, in which his name is mentioned and underlined in red. Give me one reason why I should part with this, life is more than stuffing your face and sleeping. The transportation problem? He had quickly bought a handcart for an incredible sum, since the prices for handcarts were soaring overnight, and now the little pile fills one corner of the basement.

He lays aside piece by piece, his wife watches him silently, already angrily curious, what is he looking for, maybe he even looks at the framed picture with all the members of the theater for a moment, on which he, a big man, is standing towards the right between Salzer and Strelezki, who wasn't so well known yet then. But that isn't what he is looking for, if he did look at that picture, he put it down again and keeps making the pile smaller.

"This Jacob Heym is an idiot," he says.

"Why?"

"Why! Why! He heard some news, great, but that's his business. Good news, very good news even, let him be happy but not make everyone go crazy about it."

"I don't understand you, Felix," she says. "You are unfair to nim. It is nice that we all know about it. Everybody should know about it."

"Women's logic!" says Frankfurter angrily. "Today you know of it, tomorrow the neighbors know of it, and the next day the entire ghetto is speaking of nothing else!" 
She may nod, surprised about his anger, that's how it is, so far no reason in the world to accuse this Heym of anything.

"And all of a sudden the Gestapo knows of it!" he says. "They have more ears than you think."

"But Felix," says she interrupting him, "do you seriously think the Gestapo won't find out without us where the Russians are?"

"Who is talking about that! I mean all of a sudden the Gestapo knows that there is a radio in the ghetto. And what do you think they'll do? They'll immediately turn every street upside down, one house after the other, they won't give up until they have found the radio. And where will they find one?"

The pile has been scattered, Frankfurter picks up a cardboard box, a white one or a brown one, in any case a cardboard box, in which are contained the grounds for a just and legally enforceable death sentence. He removes the lid and shows his wife the radio.

She cries out softly perhaps, she is perhaps horrified, certainly startled, she stares at the radio and at him and doesn't understand.

"You took our radio along," she whispers folding her hands. "You took our radio along, they could have shot us all for that, and I didn't know anything about it. . . I didn't know anything. .."

"What for?" he says. "What should I have told you for? I have worried enough alone and you have worried enough too even without a radio. There were days when I had forgotten about it, simply forgotten, sometimes even weeks. You have an old radio in your basement and you don't think about it any more. But the minute I remembered I would start shaking, and I have never been reminded of it in the way I was 
today. And the worst thing is, I have never listened, not one single time, not even in the beginning. Not so you wouldn't notice, I just didn't dare. Sometimes I wanted to, I almost couldn't resist my curiosity, I would take the key, and as you know I would go down to the basement from time to time. You asked me what I wanted there and I told you that I wanted to look at pictures or read the old reviews over. But that was a lie, I wanted to listen to the radio. I would come down in the basement, hang something in front of the door, but I didn't dare. I would sit down, look at the photographs or read the reviews as I had told you and I wouldn't dare. But that's the end of that now!"

"I didn't know anything," she whispers to herself.

"That's the end of that once and for all!" he says. "You were right then, it was useless stuff, I don't need it anymore. Nothing will be left of it, nothing resembling a radio. Then let them come and search."

He takes the radio apart, piece by piece, probably the only radio that exists amongst us, without much noisy ado he destroys it. The tubes are trampled to dust, an indestructible piece of wire is wrapped innocently around a box, the wooden walls of the case are put aside and will have to wait several weeks before they can be burned. For at this time of the year every smoking chimney attracts suspicious attention, but that's not so terribly serious, after all wood is wood.

"Did you hear too that the Russians are almost in Bezanika?" Frau Frankfurter asks quietly.

"I already told you that I never listened," he may have answered her. 
Mischa enters his room with Rosa and that's a whole story in itself. If indeed it makes a story how somebody else has to be lied to so that he can be a little bit happy, that's what happens with Rosa; and if it makes a story how cunning tricks have to be used, and there is fear of discovery in the game, and no goof-up for heaven's sake must happen, and one's face must be kept straight and innocent, if all that makes a useable story, then Mischa's entering his room with Rosa is a story too.

Right in the middle of the room is a folding screen.

Fajngold is the name of the man who sleeps in the other bed, Isaak Fajngold is the cause of all this to-do, even if he himself finds it ridiculous, he is completely bushed every night anyway, he is over sixty and his hair is snow white, he has other worries but what's the use. At first the chest of drawers was the only partition, that seemed adequate to Mischa and more so to Fajngold, but it wasn't good enough for Rosa. She said to Mischa, even if Fanjngold is deaf and mute, he is not blind, and the moon shines into the room so brightly, and whatever you say the chest is too small. Mischa cheerfully took the cloth off the window and tacked it next to the dresser onto the ceiling, now the moon could shine in even more brightly, but not for Fajngold, the main thing was that Rosa was happy.

Fajngold is as deaf and as mute as I or Kowalski or anyone who knows what to do with his ears and his tongue, but for Rosa he is as deaf and as mute as a clam. From the very beginning Mischa had been sure that Rosa would not take one step anywhere near his bed as long as there was another bed with a strange man inside; and all those understanding landladies and discreet hotels with doormen who look 
tactfully aside and ask no questions, those happen to all be in a different town. He knew exactly that under these circumstances she could only say no, she is not that kind of a girl, we don't even have to talk about it, and he is not that kind of a fellow either. But if one considers abstention to be the last of all possibilities, then there is still much time for careful thought, no one can blame him for that, and Mischa did this extensively.

One blessed evening he lay awake in his bed thinking of Rosa, Fajngold was just about to go to sleep in the other, and Mischa started telling him about Rosa. Who she is and what she is like and what she looks like and how much he loves her and how much she loves him, and Fajngold only sighed. Then Mischa confessed to him his burning desire to take Rosa home for a night.

"Go ahead," Fajngold answered without penetrating any further into the problem. "I have nothing against it. But now let me go to sleep." Mischa did not let him go to sleep, he explained to Fajngold that it wasn't a matter of him, Fajngold, agreeing to it, that it was only a question of Rosa's agreeing to it. And also that he hadn't told her of his existence, how dare he, and if we can't come up with a good idea then nothing will probably come of it.

Fajngold turned on the light and looked at him for a long time, wide-eyed.

"You can't mean that," he whispered, scared.

"You can't just ask me to hang around the streets during that time. Have you forgotten about the laws?"

But Mischa didn't ask for that, that idea never entered his mind, he hadn't forgotten about the laws either. He was only looking for a 
way out, but so far there was none in sight, Fajngold turned of $f$ the light again, soon he fell asleep, and it's not we who have to come up with a solution, Mischa must do it all by himself.

An hour or two later Mischa woke up Fajngold, calmly suffered the insults heaped upon him, and then he presented his idea to him. As he had said, Rosa would never come and spend the night at his place if she found out that there is another man in the room, whether he be twenty or a hundred. If he doesn't tell her, then she might come, then she will see Fajngold and leave again and never forgive Mischa. Whichever way one looks at it, the only remaining possibility is for Fajngold to stay in the room without really being there.

"Am I perhaps supposed to hide?" Fajngold asks wearily. "Am I supposed to spend the nights under the bed or in the closet?"

"I'll tell her that you are a deaf-mute," Mischa announced.

Fajngold didn't want to, he fought against it tooth and nail, but Mischa finally suceeded in convincing him of the urgency. One can't see much at night anyway, and if on top of that she is sure that you can't hear anything either, then it should be possible. With thoroughly mixed feelings Fajngold agreed, if it means so much to you, and since that time he's been as deaf and as mute as a clam for Rosa.

For Mischa, however, there was an additional worry, because he concluded from several of Fajngold's allusions that he had listened in on them once. Rosa didn't notice anything, Fajngold kept his mouth shut, but he must have heard a thing here or there that hadn't been meant for his ears. When one is in each other's arms quite a few things are said that are not meant for other ears, and Mischa was very embarrassed by it. After that he studied Fajngold's sleep, he made a 
point of staying awake for a long time, in order to pay attention to the pitch of his breathing and snoring. No one has ever heard himself sleep, one can't imitate one's own sleep. And Mischa knows what Fajngold's sleep sounds like, he would bet his right arm--he says--that he knows it exactly. And during the rare nights when Rosa is at his place, Mischa at first always lies next to her intently listening, and only when he is quite sure that Fajngold is asleep behind the screen, does he begin to caress and kiss her and Rosa forgets her disappointment about his keeping her waiting for so long.

Once something awful happened; during his sleep, in a confused dream, Fajngold suddenly started talking. Clearly distinguishable, disconnected words, despite the fact that deaf-mutes are supposed to be deaf-mute in their sleep as well. Mischa was awakened by it, his heart almost stopped beating inside his chest, he glanced fearfully towards Rosa who was lying in the moonlight sleeping and only turning her head from side to side. He couldn't shout: "Fajngold, shut up!" He could only lie there quietly and hope, and luckily Fajngold stopped dreaming before worse things happened, dreams only last a few seconds they say, and it never happened again.

So much for this mini-comedy, tortuous paths have led Rosa into this room and under this ceiling, not just straight along the road and then left and then right around the corner. Mischa made it possible, Fajngold placed himself at his disposal, and Rosa likes it here.

She is lying on her back, her hands under her head (for all I know), as usual, even if that's a little outrageous, since the bed has already more than its share with a fellow like Mischa, he has to make do 
with the edge. She's lying there, her eyes somewhere, an evening more beautiful than all the others already over, everything has already been whispered into one another's ears. Even though Fajngold is deaf and dumb, they always whisper, when two people are lying like Rosa and Mischa, then they whisper, even on lonely islands, provided something really needs to be said. The night is that far gone, the taciturn Fajngold has been asleep for a long time behind the wall of sheet and dresser. The hot day and the news must have tired him out, he was only a brief obstacle today, after a few minutes Mischa was already satisfied with the sound that drifted over to them, and he could devote all his attention to Rosa.

Rosa nudges Mischa gently, her foot against his foot, she does this with great persistence until he is awake enough to ask her what is the matter.

"My parents will live with us, won't they?" she says.

Her parents. Never yet had they made their way into this room, there had always just been that one night when one was lying together loving each other, only that one and no other, all those to come would have to wait their turn, and there wasn't much point talking about them. But there they are now, let us take a quick look at what might happen some day, just a little eyeful through a hole in the curtain. The parents are there and a whiff of the future, they can't be kicked out, Rosa insists on it.

"They won't live with us," says Mischa at this late and sleepy hour. 
"And why not? Do you have anything against them?"

Rosa's voice gets louder, these aren't things one simply breathes into someone's ear, so piercingly loud perhaps, that Fajngold could wake up, but she has no hunch of this danger.

"Good heavens, is that so important that you have to wake me up in the middle of the night?"

"Yes," says Rosa.

All right then, he leans back on his elbows, she can be pretty proud of the fact that she has ruined his sleep, he sighs, as if life wasn't difficult enough already.

"All right then: I have nothing against them, nothing at all. In fact, I like them very much; they will not live with us and now let me sleep!"

He turns over on his other side, abruptly, a little show of protest in the moonlight, there is the first disagreement. Not a real quarrel yet, just a hint of every-day cares, a few quiet minutes pass in which Mischa realizes that Fajngold has woken up.

"Mama could take care of the children," says Rosa.

"Grandmas only spoil kids," says Mischa.

"And I can't cook, either."

"There are books."

Now its her turn to sigh, let's argue about it later, there is still so much time. Rosa has to lift her head up a bit because he is slipping his arm of peace underneath, one more kiss to make up, and then it's really time to sleep. But she can't just close her eyes and run away, she sees whatever she sees, how long have we been waiting for this 
view. When they knock, when they are standing at the door, the Russians, hello, here we are, let's go, then it's really too late, one can't start deciding then, then one should already know what is to be done first and what second. But Mischa wants to sleep and Rosa can't, there is so much confusion, one should at least clear up a few things. The big things will be taken care of somehow, there'1l be important people to see to that, let's start with the personal stuff, nobody will help us with that. Rosa's thoughts turn into a whisper, first there is the house, in which one should feel comfortable; it could be something other than the house too, but let's start with that. Not too small, not too big, let's say five rooms, that isn't asking too much. Don't start yelling right away, we can ask for that much, we've been modest for long enough. And a children's room, of course, in which they can do as they please, stand on their heads and paint the walls. We would sleep in my room, not in a separate bedroom, that's a waste of space in the daytime, one has to think in practical terms. When we have guests we could sit in your room, a sofa standing freely in the room is fashionable, with a long table in front of it and three or four armchairs. But I don't want to have too many guests, you should know that right now. Not because of the disorder they create, that's no big problem, but I'd rather be alone with you. Maybe when we're a little older. And in the kitchen I will take no meddling from anyone. It has to be tiled, that looks clean and pretty, blue and white would be best. The Klosenbergs had a kitchen like that, one exactly like theirs, a prettier one than that can't be imagined. The kitchen floor will have grey tiles, along the walls there' 11 be shelves for plates and pots and ladles and a little shelf 
has to hang there for all kinds of spices. No one knows how many spices there are, saffron for example, did you know what saffron is used for? That it turns cakes and noodles yellow?

That's all I know, around here my source Mischa finally dropped off amidst all the spices. Maybe fajngold could have told me more about this night, maybe he lay awake all the way from the basement to the attic, but I didn't ask him.

Then it is day again, at last it is day again, we run back and forth with our crates in the freight yard, a few years ago one would have called it a lively bustle. The guards are behaving quite normally, they are yelling or dozing or shoving as usual, they are showing no fear, or else they know none yet. Perhaps I'm wrong, but I have the feeling that I can remember this day well myself, even though nothing unusual happened, not for me at any rate. I think today I am standing on a freight car and it's my job to receive the crates and to stack them so that as many as possible will fit in. Along with another man, Herschel Schtamm, and that actually is something special. For Herschel Schtamm has a brother, not only that, he has a twin brother Roman, and the two of them usually work and stand and walk together. But not today, Herschel had a little accident right in the morning, he tripped while carrying crates, Roman couldn't hang on to the crate by himself, and crate and Herschel fell to the ground. Herschel endured the usual beating, but that wasn't the worst of it, he had sprained his foot when he tripped, could hardly walk, couldn't keep hauling with Roman either, and that's why he is standing with me in the freight car now. 
He is sweating like a waterfall, I have never seen anyone sweat like that, he won't stop sweating until the Russians have taken this damned ghetto, not one day earlier. For Herschel Schtamm is pious. In his lifetime he was a servant in a synagogue, we call it a shammas, pious as the rabbi himself. And there are the earlocks, an ornament of all orthodox Jews, go and ask Herschel if he is willing to part with them. Not for any amount of money, he will tell you, he will look at you as if you are a madman, how can you ask a thing like that of him. But the earlocks are only allowed to see the light of day within his own four walls, only there, on the street and here in the yard one meets Germans that don't care very much for them, where do you think we are, running around looking like that! There've been some cases when one simply went to get the first pair of scissors, and the whole thing was taken care of right then and there amidst prayers and tears of laughter, but other worse cases are known as well.

Herschel drew the only possible conclusion, he hides his earlocks, he smuggles them through time. He wears a cap in summer and in winter, surely caps are still allowed, a black felt cap with flaps on each ear, which are supposed to be buttoned up under the chin. In the sun it is terribly hot, it was the only one he could get, but extremely suitable for his purposes. Those of us who aren't pious only smiled during the first warm week and made little jokes, even his brother Roman, but then our interest subsided, Herschel must know what he is doing.

We are stacking a crate on top, he wipes the sweat off his face and asks me, as we're receiving the next one, what I think of it. I know what he is talking about, I tell him that I am crazy with joy, I 
I can think of nothing else any longer. Everything I used to own will be mine again, except for my wife Chan who was shot. There will be trees again, I see myself sitting in a nut tree in my parents' garden, on such thin branches that my mother is about to faint, at the very top I gorge myself with walnuts. My fingers get so brown from the shell that it takes weeks to wash off, but Herschel doesn't seem to me to be too excited about it.

Jacob and Mischa are lifting a crate onto the edge of the freight car. What's the hurry, Jacob is taking big steps back to the pile and Mischa is scurrying behind him. Since yesterday Jacob is a lucky dog, one of the chosen few, everyone crowds around him, the giants and the little fellows, everyone wants to work with him, with the man who has a direct connection to the good Lord. Mischa was the first in line, the first one to lend a hand when Jacob's eyes focused on a crate, and now he is running behind him. It would be fairest to raffle him off, so many blanks and a first prize, then everyone would have the same chance for the big prize that has suddenly become so important: being close to Jacob. Only Jacob is making a disgruntled face, thanks a lot for such a prize, he's already been asked five or ten times since morning what the radio has been saying, all in confidence and full of hope, even by complete strangers. Five or ten times he didn't know what to answer and just repeated what he had already said yesterday, Bezanika, or he just put his finger to his mouth and said "Shhh!" like a conspirator, or he didn't say anything at all and walked on annoyed. And this whole mess all because of that lanky idiot who is trotting innocently behind him in 
undeserved anticipation, who could have predicted that? They are behaving like children, they buzz around you like eager couples around entertainment posters, unless a miracle happens it'll only be a matter of hours until the guards start noticing. A crowd like this was what one wished for in normal times, Jacob's cafe is open every day except Shabbas, throughout the year, and there is a radio clearly visible behind the counter, anyone can listen to whatever he likes. But then you stay away, then one has to treat each one of you like a king, or else you'll go and not come back, and now you're treating me like a king and won't leave and keep coming back, a bodyguard for protection against all of you is what one needs.

Mischa has no inkling of the angry thoughts that are being kindled right near him, that it is rage which causes Jacob's steps to hurry so. They carry a few crates, Mischa imagines that things will continue as they have until noon, he neglects to pay attention to the unfriendly stares he is getting from time to time and more and more often. Until the pot boils over, until Jacob stops short in the hope that Mischa will keep walking, as far away as possible. But Mischa stops too, puzzled amazement in his eyes, he really has no idea, so let him find out. "Please, Mischa," says Jacob, pained, "there are so many nice people here. Do you have to pick me to haul with?"

"What's wrong all of a sudden?"

"All of a sudden, that's funny! I can't stand to look at your face anymore!"

"My face?" Mischa smiles stupidly, his face has never bothered anyone before, least of all Jacob, just a remark here and there about 
sky-blue eyes whenever he couldn't think of anything better, and all of a sudden such a little outburst, one might almost call it an insult. "Yes your face! With that mouth of yours, that blabbermouth," Jacob adds because Mischa is so totally in the dark. And now Mischa knows which way the wind is blowing, he is the weak link in the small chain of secrecy, yes, Jacob is right. Even if there is no reason to make such a fuss, God knows there've been worse things, Mischa shrugs his shoulders, yes it happened to me, there's nothing we can do about it now. Before Jacob carries on any further, Mischa quietly steps aside, the guard doesn't have to know about our problems, later on or tomorrow there'll surely be time for a forgiving word.

So Mischa goes over to the crates by himself, he has quickly found another partner, after all he hasn't veered completely off course. His strong arms have not yet been forgotten, they are still appreciated, if you can't haul with Jacob then at least with Mischa. And Jacob too comes to the pyramid alone, he doesn't even see who is reaching for a crate with him, his eyes are still glued to Mischa, who finally disappears without turning around, insulted or not. After a few steps Jacob however does notice that his new partner isn't holding the crate as firmly as Mischa was, not nearly as firmly, and he looks up at him, and he sees that the new man is Kowalski, and he grimaces and knows that he has gone from the frying pan into the fire. Kowalski won't leave him alone for long.

Kowalski doesn't say a word. That is to say, it's not that he is just quiet, he is controlling himself, how long is he going to be able to stand it, he hauls and hauls, that's all right with Jacob. But 
somehow it does bother him; Kowalski and silence, the red dots on his cheeks aren't from exertion. For three crates not a word is spoken, if Kowalski thinks he can starve him out, he is wrong, Jacob will never open up with anything on his own, he has nothing to tell, only it is annoying. We'll outsmart you, thinks Jacob, we'll set a trap for you, an innocent conversation might make you forget the question which you are still keeping to yourself, but what can one talk about until the noon whistle blows, because then it'll be hard to find me.

"Do you know anything against, loss of hair?"

"Why?"

"Every morning my comb is full of hair. Isn't there something you can do about that?"

"Nothing," says Kowalski and Jacob clearly discerns that the subject doesn't interest him.

"There must be something you can do. It occurs to me that in your shop you rubbed some stuff on a customer. I think it was green?"

"Pure swindle," says Kowalski. "I rubbed it on many, but I might as well have rubbed water on them. Some people insist on having something. And it wasn't green, it was yellow."

"There isn't anything that will help?"

"You heard me."

That's that, they keep on hauling silently, the hope grows within Jacob that he might be wrong, that Kowalski doesn't want anything from him, that he grabbed the same crate just because he happened to be closest, and the red dots might be from exertion after all, or bugbites. How many times one doesn't think of the obvious, bad experiences shouldn't put all sincerity into doubt, Kowalski has his good 
points too, many memories can prove that. After all, one used to be pretty good friends. Jacob is already looking more kindly at the sweating Kowalski, a secret apology in his eyes, secret because the reproaches had also remained secret. Every new crate that is silently brought to the freight car leads him away from the suspicion, which was obviously directed at an innocent person.

And suddenly, not long before noon, Kowalski asks his sneaking question, without any preparation and with disarming innocence he says: "Well?"

That's all, Jacob is startled, we know what is meant. In a second all the anger is back again, Jacob feels cheated, the dots are the usual ones after all. And Kowalski didn't just happen to be standing close by, he had been waiting for him, he had ambushed him, all day long he had worked towards this shameless "well?" It wasn't out of consideration that he was being quiet until just now, Kowalski doesn't even know what that is, he was keeping quiet because he had seen that Jacob started to quarrel with Mischa and he had only been waiting for the right moment, cold and calculating as he is, Jacob was to be lulled into security.

Jacob is startled, the worst thing about this ghetto is that one can't just turn around and walk off, it isn't smart to repeat this game every five minutes.

"Is there anything new?" Kowalski asks more clearly. He doesn't feel like getting into long staring contests, if you don't get my "well?", then try this.

"No," says Jacob. 
"You mean to tell me in all seriousness that in a war nothing has happened in a whole day? A whole day and a whole night?"

They put the crate down at the edge of the freight car, go back to the pile, Jacob breathes deeply, and Kowalski nods at him encouragingly, and Jacob loses control and gets louder than might be advisable.

"For God's sake, leave me alone for once! Didn't I tell you yesterday that they are 20 kilometers from Bezanika? Isn't that good enough for you?"

Of course it isn't good enough for Kowalski if the Russians are 20 kilometers away from Bezanika and he is here, how should that be good enough for him, but he has no time for a sharp comeback, not right now, he looks around, frightened, because Jacob wasn't exactly careful. And really there is a guard standing quite close by, they'll have to walk past him, he is staring already. The uniform doesn't look good on him, he is much too young for it, he has already made himself known a few times, he is a big-mouth, but he hasn't often beaten anyone yet.

"What are you two fleabags arguing about?" he asks, just as they are about to pass him. In any case he didn't hear anything specific, only loud words that can be explained quickly.

"We are not arguing, sir," says Kowalski loudly, "it's just that I'm a bit hard of hearing."

The guard has something to inspect and to rock on his toes about, then he turns around and goes away. Kowalski and Jacob get a new crate and the incident is not considered worthy of comment.

"A whole day has gone by, Jacob. Twenty-four long hours. Surely they have advanced by a few measly kilometers?" 
"Yes, three kilometers according to the latest reports."

"And you act so indifferent? Every meter counts, I'll tell you, every single meter!"

"What are three kilometers, really," says Jacob.

"Oh, yeah? It may not be much for you, you hear something new every day. But three kilometers is three kilometers!"

That's over with, for today Kowalski will leave him alone, he is now as silent as Fajngold, he found out what he wanted.

Jacob admits to himself that it wasn't so bad, actually it came out quite easily, he explained it to me at great length, it was an important moment for him, he said. The very first lie that maybe wasn't even one, it was so small, and Kowalski is happy. It is worth that, hope must not wither away or they won't survive, he knows for sure that the Russians are advancing, he heard it with his own ears, and if there is a God in Heaven then they must get to us, and if there isn't one they must get to us too and they must find as many survivors as possible, it is worth that. Only he has to have enough ideas, they'll keep asking new questions, they'll want to know the details, not just numbers of kilometers, he'll have to find the answers. If only his head cooperates, inventing isn't everyone's bag, up until now he has only invented one single thing in his life, that was years ago, a new potato pancake recipe with cream cheese and onions and caraway seeds, you really can't compare those two.

"And besides, it is important that they are at least advancing," says Kowalski thoughtfully. "You understand, better forward slowly than quickly back. . ." 
At last we are getting to Lena, irresponsibly late, because she is of some importance in all this, she's the one who rounds it out, if one can speak like that, Jacob goes to see her every day but we are just getting around to it now.

Lena is eight years old, long black hair and brown eyes as is proper, a strikingly beautiful child, most people say. She can look at you so as to make you want to share the last bite with her, but only Jacob does that, sometimes he even gives her all, that's because he has never had children of his own.

It has been two years since Lena had parents, they went away, they got into the freight train and went away, leaving behind their only child all alone. Lena's father was walking in the street almost two years ago, no one pointed out to him that he was wearing the wrong jacket, the jacket without stars. It was the beginning of autumn, he was walking along thinking no evil, they would have noticed it at work anyway, but he never got that far. Halfway there he ran into a patrol, one attentive glance was enough, only Nuriel didn't know what to make of it.

"Are you married?" one of the two asked him.

"Yes," Nuriel said, not suspecting what they wanted from him with that odd question.

"Where does your wife work?"

In such and such a place, Nuriel answered. They went there with him immediately and got the woman out of the factory. The moment she saw him with the two men she noticed the bare spots on Nuriel's chest and back, and she looked at him, horrified, and Nuriel said to her: "I don't know what's wrong either." 
"Your stars," she whispered.

Nuriel glanced down at himself, now he knew this was the end, or almost, a much more trivial reason could have meant the end, just read the ghetto regulations. They went home with Nuriel and his wife, on the way they told them what they were allowed to take along. Lena was not playing in front of the house, she wasn't in the hallway either, her mother had warned her not to leave the apartment if possible. But one never knows what children will do all day while their parents are at work, a prayer to heaven that she disobeyed this one time. She wasn't in the room either, so she couldn't be surprised and ask what's the matter, why papa and momma are already home, and the men would have known that Nuriel didn't just have a wife. They packed their few things, the two men stood beside them watching to see that there was no tricky business going on. Nuriel behaved like a sleepwalker until his wife nudged him and told him to hurry. And now he did start to hurry, he understood her request, any moment Lena might come into the room.

Going downstairs he could see through a window in the stairwell that Lena was playing in the courtyard (all this without any witnesses, but maybe it happened just this way and no other). She was balancing herself on the little wall between the two courtyards, how many times he had told her not to, but that's how children are. A neighbor who happened to work nights that week met them on the stairs, she heard Nuriel's wife tell him not to keep looking through that window but to pay attention to the steps or else he would fall. And he did, he did not fall, they reached the street without any mishap, and since that day Lena has no more parents. 
A short time later a new family was assigned to the Nuriels' room, at that time newcomers were arriving all the time. A problem arose: what to do with Lena, no one could take her in permanently, not only for reasons of space or ill will; all it would take was a surprise inspection, how do you come to have this child? Everyone waited for weeks, wondering if Lena would be traced, someone in some administrative office might notice while looking through some papers, that instead of three Nuriels only two had left in the transport, but nothing like that happened. Finally a few women in the house cleaned the little attic, the bed was moved upstairs and a dresser with her things, which were still around. Lena lives on the top floor. Only a heater couldn't be found. In the coldest nights when even two blankets don't help, Jacob, who has never had children of his own, risks it and sneaks her into his bed. It just happened that she belongs to him the most, she's had two years to wrap him around her little finger, and that was plenty of time. Today it is not a cold night, let alone the coldest, Lena will have to sleep alone, Herschell Schtamm sweated horribly all day long. Jacob comes to see her, every evening he comes to see her, Lena is lying there with her eyes closed. Jacob knows very well that she is not sleeping and she knows that he knows, every night there's a different trick. He takes a bag out of his pocket, in the bag is a carrot, he puts it on the dresser next to the bed, then he plays his trick for today. He blows up the bag and pops it between his hands, but Lena is already laughing before that, her eyes still closed, something is bound to happen. And then, of course, there is a bang, Lena sits up, gives him his well-earned kiss and claims that she already feels much better. 
Tomorrow she really wants to get up, such a whooping cough can't last forever, but Jacob isn't the only one to make that decision. He tests her forehead with his hand.

"Do I still have a fever?" asks Lena.

"A little bit at the very most, if my thermometer is working right."

She takes the carrot, asks him what that is, fever, and starts to eat.

"I'll explain that to you another time," says Jacob. "Has the Professor already been here today?"

No, not yet, but he said yesterday that things are looking up, and Jacob shouldn't keep putting her off, he still has to explain to her what gas masks are and epidemics, and balloons, and martial law, the other things she can't remember, and now he owes her fever too.

Jacob lets her talk, she already seems pretty chipper, he is maybe thinking a little longingly of the three cigarettes the carrot cost him, he'll have to get the next one for cheaper. And finally everything ends in conversation, Lena is a master of conversation, she must have been born that way.

"How is work?" she asks.

"Just fine," says Jacob, "thank you for asking."

"Was it really hot at work today too? It was mighty warm here."

"Not bad."

"What did you do today? Did you ride in the locomotive again?"

"What gives you that idea?"

"The other day you drove to Rudpol and back, don't you remember?" 
"Oh, yes. But not today, the locomotive has been broken the last few days."

"What's wrong with it?"

"It lost a wheel, and there isn't a new one."

"Too bad. How is Mischa? He hasn't been here for such a long time?"

"He is very busy. But it's good you remind me, he says to say hello to you."

"Thanks," says Lena. "Say hello to him from me too."

"Will do."

And this could go on for hours, for over twenty carrots, no matter what they are chatting about, they are talking together, until the door opens, until Kirschbaum comes in.

If I hadn't had something different in mind all along, I would tell Kirschbaum's story,maybe I'll still do it some time, it's quite a temptation. Even though we only saw each other briefly two or three times, he didn't even know my name. I actually only know him from Jacob's few words, he mentioned him almost in passing, but he did arouse my curiosity; Kirscbaum doesn't play a large role in this whole thing, mostly he cured Lena. Kirschbaum used to be a celebrity years ago, not like Rosa's father, but an honest-to-goodness celebrity with seal and signature and a million honors, head of a Cracow hospital, well-known heart specialist. Lectures at universities all over the world, fluent in French, Spanish and German, he is supposed to have corresponded with Albert Schweitzer off and on. Whoever wanted to be cured by him had to 
go to all kinds of trouble, and to this day that person carries with him the fame of that highly regarded man, with no contribution of his own. And even his suits, made of the best British fabrics, a bit worn at the knees and elbows by now, but always a flawless fit, all of them of dark colors as an effective contrast to his snow-white hair.

Kirschbaum never devoted a thought to the fact that he is a Jew, his father had already been a surgeon, what does that really mean: Jewish origin? They force you to be a Jew and one has no concept of what that really is. Now there are Jews all around him, for the first time in his life nothing but Jews, he racked his brains about them, he wanted to find out what it is, what distinguished them all, but to no avail, they don't have anything noticeably in common, and least of all he with them.

For most he is a kind of prodigy, Kirschbaum feels uncomfortable with that, better friendliness than respect, he tries to fit in. He does it clumsily, and, of course, everybody expects something special from him, but he lacks the necessary humor.

He comes into the attic, he brings with him a pot full of soup for Lena, his gait is elastic as though he were still in his thirties, the tennis club kept him young.

"Good evening, everybody," he says.

"Good evening, Professor."

Jacob gets up from the bed, he makes room for Kirschbaum who is going to examine Lena in a minute, she is already taking her shirt off, the soup is still too hot, the examination always comes first. Jacob goes to the window, it is open, a little attic window, but one can still 
see half the town. Perhaps a sunset, the houses steeped in grey and gold and peace all around. The Russians will march through all the streets, not one will be left out, the damned stars will come off the doors and leave light spots like ugly pictures that have hung on the wall too long and deserve to wander into the trash can. At last one will have a little time for rosy thoughts, like the others, just as though it had been Kowalski through whom one had heard about the miracle: that the future lies hidden somewhere down there, no more big adventures, let the young men rush into those, certainly the cafe will have to be repainted, perhaps a few new tables added, if possible even a taproom licence for which there was practically no hope at the time, we will see. The store room could be fixed up as Lena's room, let's hope no relatives burst in to claim her, only the parents will get her, but will they still be around? Next year she'll start school, ridiculous, a young lady nine years old in the first grade. The first grade will be full of children who are too big, maybe they'll think of something, so that they won't lose so much time. It would be good if one could teach her a bit ahead of time, at least reading and a little arithmetic, why hadn't one thought of that before, let her get well first.

"Now I can tell you," says Kirschbaum. "It looked pretty bad for this young lady. But with good ladies something can usually be done. We've pretty well fixed the trouble. Take a deep breath and hold it!"

Downstairs in the closet is an old book, a travelogue about Africa or America, one could use that for learning to read, it even has a few pictures. One will have to make it appealing somehow, because if she doesn't want to, you can stand on your head. As soon as possible I will 
adopt her, but first, of course, search for her parents without her finding out, adopting isn't supposed to be easy, a lot of formalities and red tape, one did make it to having a child, and in one's old age at that. The Germans have their part in it and the Russians have their part in it, who has the bigger one? I'll tell her that this is the end of all the telling of fairy tales, of nothing but princes and witches and wizards and robbers all the time, reality looks quite different, you are old enough, this here is an $A$. For sure she' 11 ask what that means, an $A$, she'll want to know what it is used for, she is very practical-minded, at her age questions make up half of life, there might be hard times ahead. As a child she is already eight years old, and I as a father barely two.

Kirschbaum is holding the stethoscope to her chest and listening intentiy, and suddenly he acts very surprised, stares a Lena and asks: "What's this? Isn't there something whistling in there?"

Lena looks over at Jacob, amused, and he keeps on, he hadn't even noticed that he had started, but now he keeps going, he is not going to spoil the weak little joke for Kirschbaum, and Lena laughs about the dumb professor, who doesn't understand that the whistling doesn't come from her chest but from Uncle Jacob.

What do they mean: great events are always foreshadowed, one asks oneself, since there is no sign of foreshadowing, a few trivial days go by, trivial for the historians. No new regulations, no external event, nothing concrete, nothing that could be interpreted as change. A few claim to have noticed that the Germans have become more reserved, a few 
say, since there isn't a thing happening, that it is the calm before a storm. But I say this calm before the storm is a lie, absolutely nothing is a lie, the storm is already here, or a part of it anyway, the whispering in the rooms with all the fear and speculation, hope and prayer, the great age of the prophets has begun. Whenever two are arguing they are arguing about plans, mine is better than yours, all of them are in its grip, all of them know of the inconceivable. Whoever doesn't know yet must be a hermit, not everyone knows where the news came from, the ghetto is too big for that, but the Russians are in everyone's head. 01d debts begin to play a role, they are mentioned with embarrassment, daughters change into brides, the week before New Years' the wedding is to take place, people are going completely crazy, the suicide figure drops down to zero.

Whoever is shot now, so close to the end, has suddenly lost a future, for heaven's sake don't give them any reason for Maidanek or Auschwitz, inasmuch as reasons have any part in it, take care, Jews, the utmost care and no thoughtless steps.

For a time there has been a split right through the town, two parties have formed, Jacob doesn't only have friends, two parties without any charter but with weighty arguments and platforms and rhetoric. One lusts after news, what happened last night, how heavy are the losses on each side, no report is so insignificant that something couldn't be concluded from it. And the others have heard enough, Frankfurter's party, for them this radio is a source of constant danger, Jacob could calm them down so easily, I hear their worries in the yard and on the way home and in the house. In all your innocence you are 
risking our heads and necks, they warn, the Germans are neither deaf nor blind. And the ghetto regulations aren't some guideline for good behavior, it says there in black and white what it means to listen to a radio, it also says what happens to those who know that someone is listening and fail to report it. Therefore, calm down and wait quietly in your corner, when the Russians are here, they are here, you aren't going to make them appear through gossiping. And, above all, stop talking about this wretched radio, this reason for a thousand possible deaths, it would be better to destroy it today than to wait until tomorrow.

That's the situation, Jacob doesn't only have friends, but he doesn't notice that, he can't possibly find out. Those who crowd around him, the curious ones, the hundred Kowalskis, won't dream of telling him, for Jacob could have second thoughts and change his mind and suddenly start keeping quiet. Then it is better for them to keep quiet. As for those who continue to warn, they won't tell him for sure, they are not going to send him a stern delegation, that would be much too risky. They make a big detour around Jacob, for no one should ever be able to say that they were seen anywhere near him.

Herschel Schtamm with his earlocks, for example, is one of the others, one of those who don't want to hear nor see anything any more nor be an accessory. Whenever we are in the yard, with our hands in front of our mouths, evaluating the latest triumphs of the Russians, fresh from Jacob's mouth, he always stands a few steps away, yet not so very far, still within earshot, by my guess. As long as it isn't a conversation in which he seems to be taking part, that's his obvious 
worry. Herschel's glances wander indifferently over the tracks or they meet one of us with disapproving fierceness, but it is not inconceivable that under his sweaty fur cap his ears are perking up like a rabbit's. The power failure, which for days turns Jacob's radio into a dangerous dust collector, he attributes to his personal success. He doesn't say this in public, of course, Herschel is not the man to brag, we know it from his twin brother Roman, who spends every evening and every morning in the same room and every night in the same bed; after all, he should know. When we ask Herschel how he managed that feat, a black-out in several streets for several days isn't child's play, then his face turns gentle, there is a hint of a smile for having braved such danger, but he does not say a word. And then we ask: "How did it happen, Roman? How did he manage it?"

The minutes before going to bed, Roman reports, are filled with prayers, quietly in a corner, not just since the radio, it's an old habit. Roman waits patiently in bed until it is time to pull the common blanket over his head, he has given up long ago demanding that Herschel hurry up and come to bed, he has been taught that prayers and hurry mustn't have anything to do with each other. He doesn't pay attention to the monotonous mumbling and singing, there wouldn't be any point, Roman doesn't understand a word of Hebrew, but for some time now familiar sounds have been reaching his ears as well. Since ${ }^{\circ}$ Herschel has had concrete requests to send to the good Lord, not just the usual pious stuff about protecting and somehow turning everything to good, he has more and more often been using the language that is generally understood. Roman can now catch a few fragments of what is worrying and 
tormenting his brother, nothing unusual, if one prayed oneself one wouldn't have anything very different to say either. Evening after evening God is told of hunger, of fear and deportation and beatings from the guards, which can't possibly all be happening with His approval, wouldn't He kindly see what can be done about it, quickly if possible, it's urgent, and would He give a sign that one has been heard. The sign was long in coming, an outstanding feat of perserverance for Herschel, each day in turn was carefully examined for proof of God's intervention. And then it did come, that longed-for sign, sudden as all divine action and so powerful that all words of doubt had to vanish from the lips of even the most skeptical.

The radio was the topic that evening, this worry that ruled over everything at the moment, Herschel is explaining to God in great detail the immense consequences should thoughtlessness and lack of caution cause the chattermouths to overlook a German ear, that'll be it, the chattermouths will be called to account and the silent accessories too. And it will be maintained that we are all accessories, that the news caught up with everyone, and they will even be right about that. Besides, it needn't just be a German ear that happens to be standing close by, there are also German ears in disguise, only You know how many spies there are running around in our midst. Or someone wants to save his own skin and betrays it all on his own, there are scoundrels everywhere, You know that too, without Your consent they wouldn't exist in this world. Don't let that big misfortune happen to us so close to the end, when all these years you have been holding your protective hand over us and prevented the worst, don't let it happen, for Your own sake. 
Don't let the Germans find out about the radio, You know what they are capable of. Or even better, if I may make this suggestion to You, destroy this cursed radio, that would be the best solution.

And there the lightbulb under the ceiling suddenly begins to flicker, Herschel doesn't pay attention to it at first, but then he looks up, wide-eyed, in a flash all is bright, what can that mean. God heard him, the prayers weren't in vain, He is sending His sign just at the right time, as a receipt, a sign that couldn't possibly have been more useful, that's what God is for! Without electricity the radio will be condemned to silence, the light flickers harder and harder as Herschel prays more and more fervently. "Keep it up!" Roman spurs him on, but he doesn't have to tell him that, Herschel knows what's up, advice from scoffers is not needed when bliss beckons as a reward. Full of devotion he keeps his connections working until it is accomplished, the lamp goes out completely, the last word has been spoken. Herschel dashes to the window, intent glances to the other side of Jacob Heym's house. We've managed to silence you, old friend, heavenly peace will reign, take your wretched old box to the devil, you won't be able to use it now. And don't imagine for a moment that the power failure, which you in your thought lessness consider an evil, will be fixed tomorrow, short circuits from the highest place of all last for some time. Proud and happy, in as far as the circumstances will permit, Herschel lies down in bed after his accomplished task and coolly accepts Roman's congratulations. 
Worried faces all around Jacob, what's up, we're left high and dry without any idea of what's happening in the world. This unbearable situation is already in its third day, this is no longer a power failure, it's a natural disaster, does this have to happen to us on top of everything else? One had gotten used to the joyous news too quickly, one has become hooked on a few kilometers every morning, all day long there was something to hope for and to talk about. And now an oppressive silence prevails, our first step in the morning led us to the light switch, some even got up in the middle of the night, we flicked the switch and there was the answer we had feared: that today too Jacob is no wiser than the rest of us. Only electricity will render him omniscient again, only the electricity that has been cut by obscure powers, only when all the lamps are burning again will his light shine especially brightly, but when will that be.

The only one for whom this new cause for worry isn't one is named Jacob, for once a stroke of fate has spared him. His connection to the outside world has not been cut, what isn't there can't be cut, it's as weak as ever, but now he can finally admit it. It's pure madness what kinds of utensils good fortune chooses to cook with (modest as this good fortune is), in the disguise of a power failure, let it continue until the first Russian faces surprise the guards at the edge of the city. At least he can now breathe more freely, Jacob can again be one of many, nobody forces him to know more than all the others, but he must go on pretending. All the time he must pretend, he must feign regret where there is none, regret about the blackout, and that's no small matter when he feels such relief. You've seen it, friends, I am doing all I 
can, for as long as it was possible I've delivered the latest and best to you, not for one day were you left without a hopeful report, how I would love to keep reporting up until that great and wished-for hour, but my hands are tied, you can see that yourself.

In the morning Kowalski again is the winner, he is loading wih Jacob, only this time it wasn't a real race any more, over night Jacob has turned into an ordinary worker, an older person with two amazingly weak hands that no one fights over any longer. Kowalski wound up with Jacob, out of habit more than anything else, or old friendship, in any case they are loading together. It hasn't been this quiet between the two for a long time, the crates seem a trifle lighter to Jacob ever since Kowalski and the others have stopped showering him with questions, but probably heavier to Kowalski, since the answers are missing; weight, as one can see, is not an absolute measure. The last question was whether--God forbid--the light had also failed in Jacob's house, Jacob answered simply and truthfully, Yes, he was quite happy to be able to tell the mere truth, and since then it is as quiet around him as around anyone else. And it will stay that way until that electrictiy flows again, so don't anyone be surprised at Jacob's composure.

When the whistle blows for the soup, they sit down beside each other in the sun, Kowalski sighs and slurps and sighs, it's not because of the soup which doesn't taste any better or worse than any other day. Recently Jacob has learned to fear Kowalski's company, Kowalski was the most eager of the curious, he didn't let him eat or sleep, he only used Jacob as a vehicle for his curiosity, without mercy. But today the sun is shining, one is sitting peacefully and quietly next to each other, 
eating, and somewhere in the distance Stalin's soldiers are approaching with unknown speed.

"How much longer do you think the power failure is going to last?" asks Kowalski.

"Twenty years, I hope," says Jacob.

Kowalski looks up from his bowl, hurt, that is no answer between friends. Of course the last few days haven't been easy for Jacob, our only connection to the outside world which no one wanted to ignore, you've been besieged and squeeezed, and it wasn't totally without risk either, but does one shy back from that little bit of extra trouble in our circumstances? Who would have acted differently in your place, search for him among us and you won't find him--and then one gets such an ugly response to one's modest question.

"Why are you so mean?" asks Kowalski.

"You'll never guess," says Jacob.

Kowalski shrugs his shoulders and goes on eating, today you can't talk to Jacob, maybe he is in a bad mood, there've always been days when he wanted to pick a fight for no reason. One would come into his uncomfortable cafe in the best mood and sit down at one of the many empty tables and ask Jacob as usual how business was going, and then it could happen that he didn't answer as usual: business is going thus and so, as one might expect from a grown man, but instead he would yell at you. "Don't ask such stupid questions, all you need to do is look around!" 
Not entirely by accident do Kowalski and Jacob get company, Mischa sits down beside them and brings along Schwoch, the junior partner of Lifschitz \& Schwoch, Ink Pads, Wholesale and Retail. At first Jacob thinks they're sitting down simply because there is room here, sun and an unwatched little spot, until he discovers that they are looking at each other all the time, Mischa encouragingly and Schwoch indecisively. Then he knows that it isn't coincidence after all, some unknown factor is in this game, he has learned to pay attention to the finest nuances. Mischa's glances mean: "Go on, start talking," and Schwoch's glances mean: "No, you start talking," and when it looks as though there'll be no end to glances, Jacob says in between two spoonfuls: "I'm 1istening."

"We have an idea, Jacob," says Schwoch.

So far, so good, there is always a way to use a decent idea, good ideas are like the air one breathes, let's hear what you have thought of, then we'11 see.

But Schwoch clams up after his timid opening, he glances back at Mischa, and his eyes say: "You start talking."

"The thing is," says Mischa, "we've been thinking, if the electricity won't come to the radio, then the radio will have to come to the electricity."

"Are you trying to give me riddles?" asks Jacob worried, when there is really no riddle in Mischa's words, they mean no more and no less than that in some street in this ghetto the lights are still burning, we'll soon hear in which one, it doesn't take much common sense to figure that out.

"In Kowalski's street there is electricity," says Schwoch. 
This fateful sentence uttered for Jacob's benefit hits Kowalski as he is scraping out his bowl. His hand stops, he closes his eyes for a short moment, his lips whisper angrily: may Schwoch drop dead, and he moves aside. Not far, only a few symbolic centimeters away. He hasn't heard a thing, let these madmen say whatever they want, it's none of his business.

Jacob noticed this little disclosure, too bad one can't smile, there are important things to be done before the break is over and Mischa's and Schwoch's idea starts spreading and gaining acceptance. That they won't be able to twist Kowalski's arm is as clear to Jacob as anything, there is no danger from that direction, whoever has lived within earshot of Kowalski for so many years knows what a hero doesn't look like. Trimming your beard in the latest fashion, arranging your hair so cleverly that people on the street turn around to look at you, at that he might be good, but listening to broadcasts prohibited on penalty of death and circulating their contents, for that you'll have to find someone dumber. The problem lies in no way with Kowalski, the real worry is that someone else might be found, Kowalski's street is long. Someone else might come along and say give me that thing, we'll let it play and sing and proclaim heaven on earth.

One will have to dissuade them entirely from their plan, if nothing comes of the whole thing (and nothing will come of it), then it will have to have been the plan that was at fault, not Kowalski. He must come out of this whole business as an honorable man, one will have to find words that discredit the underlying idea and prove its utter pointlessness. Well then, let's have such a proof, but where can one 
get it in such a hurry, maybe Kowalski will think of something. Because for once he is Jacob's ally, at last one is sitting in the same uncomfortable boat, Kowalski too will start gnawing away with all his might at Mischa's and Schwoch's idea, he will say everthing except that he is too scared. One will have to push him into the water up to his neck, then he'll talk, the only thing left to hope for is that tongues of angels will grow in his mouth within a very short time.

"Did you hear what they want from you?" says Jacob.

Kowalski turns his head toward him, he acts as though his mind has been elsewhere and asks in utter innocence:

"From me?" And then he asks Schwoch: "What?"

"It's about the electricity," Schwoch explains patiently. "Couldn't one bring the radio to your place?"

Kowalski acts as if he has just heard a bad joke. "To my place?" "Yes."

"The radio?"

"Yes."

"Excellent."

These idiots want to kill me, he's probably thinking, they want to ruin me, as if I wasn't loaded down with enough tsoris already, and they are talking of my downfall as if it was the most natural thing in the wor $1 d$.

"And you, Jacob? What do you think of it?"

"Why not?" says Jacob. "It's up to you. It's OK with me."

It only looks as though he is playing with fire, he knows his friend Kowalski, and besides, should Kowalski suddenly blossom into a hero, one can always change one's mind about it then. But according 
to all human calculations that will not be necessary, Kowalski is an arithmetic problem for first graders.

"Do you know what risks you are taking with this?" asks Kowalski, terribly surprised about such lack of caution. "What does that mean, one could bring the radio over to my place? Who is that 'one'? Me? You? He? Who is one? Are you people planning to carry the radio through the ghetto in broad daylight? Or even better, at night, after eight maybe."

He leans back, outraged, it's almost funny what they are proposing, and they claim to be smart.

"A parade is what they are planning! The patrols and the guards will go to sleep during that time, and when it's all done, we'll go and wake them up and tell them, now you can go back to your jobs, the radio is safely at Kowalski's!"

Schwoch and Mischa look at each other worriedly, on close inspection their plan doesn't seem quite so brilliant any more, Jacob contributes a few ominous glances as well, serious and filled with doubt. Kowalski's impressive words seem to have made even him think twice.

"And there is another important point," says Kowalski. "The fact that there is a radio in the ghetto is known to many people, but who has any idea that it is at Jacob's? Only we here in the yard and at most his neighbors. If until now everything has gone smoothly, that is, if the Germans don't have a clue yet, then decent people must be living in Jacob's house. But how do you know that it is the same in my house? I live together with three men, who can guarantee that there isn't a 
traitor or a coward living above me or next to me or below me? And that he happens to have nothing more pressing to do than to run to the Gestapo and tell all he knows?"

A long pause, Kowalski's words are being mulled over and weighed and Schwoch says softly: "Shit, he's right."

And Mischa shrugs his shoulders indecisively, and Jacob stands up and says: "If that's what you think. . ."

"Don't be in such a dangerous hurry, you kids," says Kowalski, the electricity will come back some time. If not tomorrow, then the day after. And then Jacob can still tell us soon enough how far they've advanced.

By the time the whistle blows again for work Mischa's and Schwoch's plan is dead and buried. It's been thoroughty discussed, as is proper among intelligent beings, its weak points have been brought to light and it has not withstood its glow. It would have been rather nice, it's a shame, but a clear head opened up our eyes. Schwoch and Mischa put their empty bowls in the handcart, they are almost the last ones, the guard is already staring impatiently and threateningly.

And again Jacob and Kowalski are a lonesome pair, they have both been freed of one worry, at least that's over with.

"Ideas those guys have!" says Kowalski, amused, more to himself than to Jacob, and this brings this chapter to a close.

Lena is standing around idly in the doorway looking at Rafael and Siegfried who are sitting on the curb talking softly to each other, too softly and cautiously as it seems to her, as soon as someone walks by 
they stop talking and start blinking innocently into the sun. Lena perks up her ears in vain, then her reluctance quickly melts away, she strolls across the street, what might those two showoffs have to whisper about. She catches Siegfried's claim that there isn't much more time left, and Rafael says that at home they are saying that at most it would be a few more days.

Then she is discovered. The two look at her indifferently and wait with expressionless faces for the end of the interruption. But they can keep on waiting, Lena isn't'walking on, she stays where she is and smiles politely. Until Rafael finally stands up.

"Come on. She doesn't have to hear what we're talking about," he says.

That's exactly Siegfried's opinion too. He stands up and towers before Lena, without concealing to her that he'd like to beat her up if she wasn't just a wimpy girl. Lena takes the threat quite calmly since the two are already turning around and will eventually disappear into their house, but still. Lena waits another few seconds, Jacob has strictly forbidden her to go into strange houses, but he is far away and Lena follows them. Poking her head cautiously through the courtyard door, she just catches sight of Siegfried and Rafael disappearing into the shed, where the cabinet maker Panno used to run his workshop in happier times, to this day it stinks of glue. The shed window no longer has any glass panes, Lena knows this without having to check, she was there herself when Rafael smashed the last one on his first throw. So their black thoughts won't remain hidden from her for long, not from her, she tiptoes underneath the dark window and crouches quietly on the ground. As far as she is concerned they can now begin. 
"The one thing we could do is blow up the police station," she hears Siegfried's voice.

"And if they catch us?" asks Rafael.

"Don't shit your pants about it. The Russians are coming soon, you heard that. And anyway, they can't catch us if we blow them up because by then they'll all be dead. Only we mustn't let ourselves run into any snags ahead of time."

Siegfried has always been a loudmouth, Lena could bet right then and there that nothing will come of this.

"Will the Russian officer give us something if we succeed?" asks the greedy Rafael.

"What do you think! A medal or a real pistol or something to eat!"

"Or all of those?"

"For sure! Isn't that worth it? They don't have to find out about it at home."

Silence for one second and then for one more, surely the two blockheads are imagining what the Russians will pull out of their lavishly stuffed pockets, in order to reward them for their heroic deeds.

Suddenly Rafael says sadly: "Hey. . .It won't work." "Why?"

"Where are we going to get the dynamite? If I empty my two cartridges, that'll never be enough."

"That's true. Don't you guys have any more?"

"No." 
"Neither do we."

Lena laughs, holding her hand in front of her mouth to keep it from squealing, really, it is hard to believe how dumb two ten-year-old rascals can be.

Rafael has a new idea. "Do you know what? We'll just lock them in!"

"Whom?"

"The Gestapos, of course! We'll just lock up the police station. At night they're all asleep, and then we'll lock them in. The doors are at least this thick, and they themselves put bars in front of the windows, they won't be able to get out so quickly. And then, when the Russkis are here, we'll get them all with one blow." Rafael can hardly catch his breath from excitement.

"But we don't have a key!"

"We'll find one," says Rafael confidently. "In my old man's drawer there's a bunch with at least twenty of them. One of them is bound to fit."

"Not too bad," mumbles Siegfried. One can clearly hear how annoyed he is because he didn't come up with this excellent idea himself. He would love to find fault with Rafi's plan, but it's a good one.

Then the courtyard door opens, the little Frau Bujok appears looking for her ill-bred son, but she doesn't see him, all she sees is Lena crouching on the ground, smiling.

"Have you seen Siegfried?" 
Lena is a bit startled, she was so absorbed, she looks up at Frau Bujok and regains her smile. The "wimpy girl" is still on her mind, one ought to strike while the iron is hot, Lena points her thumb at at the shed behind her. Frau Bujok looks threateningly at the shed, stands still for another short moment to take a deep breath, then marches in. One hears a not too soft slap, and then one hears "ouch!" and "how many times do I have to tell you to stay in front of the window," and one hears yet another slap and "you go home too, you devil!"

Then peace descends upon the yard, Lena stands up and dusts off her skirt, the performance is over. Frau Bujok comes out of the shed, anger has painted her face red, Siegfried hangs on to her with one hand, with the other he is holding his cheek. At least he isn't bawling. They leave the yard quickly, Siegfried doesn't see Lena.

Lena too goes to the yard door, she is in no hurry, she could even stay a bit longer, but Rafael is alone now and the listening post has lost its value. He might even stop to talk to her, but she doesn't give a hoot about that, she doesn't feel like it any more. Let him sit and rack his brain over which one of the twenty keys fits, nothing will come of it anyway.

We11, she leaves, in the doorway she turns around once more, Rafael is taking his time.

"You guys are pretty stupid!" she calls out through the courtyard towards the shed, not exactly making herself popular that way.

And the resistance, you will ask, what happened to the resistance? Are the heros maybe assembling in the shoe factory or on the freight 
yard, at least a few of them? Have obscure canals been discovered at the southern border, which, being the most mountainous, is the hardest to patrol, and have weapons been smuggled through them and into the ghetto? Or are there in this wretched city nothing but hands that will carry out exactly what Hardtloff and his guards demand of them?

Condemn them, keep condemning us, there were only hands like that. Not a single just shot was fired, law and order were strictly maintained, not a sign of resistance. I will simply have to state that I think there was no resistance, I am not omniscient, but I make my claim, as they say, with a degree of probability that borders on certainty. If there had been any, I would surely have had to notice it.

I would have taken part, I can swear to that, all they would have needed to do was ask me, even if it had been for Chana's sake. Unfortunately I am not one of the exceptional kind who calls others to battle, I am not one to sweep others along, but I would have taken part. And not just I, why couldn't the man have been found to have called "follow me!", the last few hundred kilometers needn't have been so long and so hard. The worst that could have happened to us would have been a meaningful death.

I'1l say this: it is with reverence that I have since read of Warsaw and Buchenwald, another world, yet comparable. I have read a lot about heroism, probably too much, pointless envy overwhelmed me, but no one needs to believe me. In any case, we sat still until the last moment, and there is nothing I can do to change that. I am not unaware of the fact that an oppressed people can only become really free once it starts to participate in its own liberation, when it comes to meet the 
Messiah at least a small part of the way. We didn't do that, I didn't budge from that spot, I memorized the regulations, strictly observed them and only asked Jacob from time to time what kinds of news had been reported. I'll probably never get over it, I deserve no better, my whole personal stuff about the trees must have something to do with it, as well as my bad sentimentality and the generosity of my tearducts. In the place where I was there was no resistance.

What is good for your enemies is bad for you, they say. I don't intend to quarrel about it, it would only make sense with concrete examples anyway, with the kind of example such as I have now, but I don't want to quarrel about it. My example is the electricity. It's easy for Jacob to do without it, he manages beautifully this way, what do you mean: do without?, nobody would ever have imagined how nice having no electricity can be. Aside from the Russians and good health for Lena, Jacob desires nothing as much as no electricity. But Jacob is only one and we are many, we want electricity, we are helpless victims of our imagination, if we can't have our saviors right away then at least we want electrictiy.

The Germans, to get back to my example, want electricity too, not only because one ruins one's eyes by candlelight at the police station. The carefully worked out plans get all mixed up, not a chair nor a buffet leaves the furniture factory, pliers and hammers and screws from the tool factory are lacking, no shoes, no pants, the Jews are sitting around twiddling their thumbs. Two squads of hastily assembled electricians swarm out to locate the damage, special allocations with double rations of bread and cigarettes, day and night they test the 
fuses and whatever else is to be tested, digging up streets, exposing cables, accompanied by our good wishes. After five fruitless days Hardtloff has them shot, there is talk of sabotage, which is sheer madness, the electricians were somehow all customers of Jacob's and had a personal interest in correcting the defect. On the square in front of the police station they are shot, whoever wants to can watch, let that be a warning to you and do what is demanded of you.

Then a German technical squad arrives in a truck like men from Mars. Uniforms like divers, one sees them laugh and enjoy their importance, we'll fix this baby, Erika, let's see what Jewish bunglers beat their brains out about. Two days, then the sore spot lies bare, a swarm of rats had gnawed through a cable and perished from their greed, a new cable is buried in the ground and once again buffets, shoes, pliers, screws, Jacob's radio.

We want to know if it is true that they wanted to sell us for a ransom. If so, where is the money? We want to know if it is a fact that a Jewish state is to be established. If so, when? If not, who is preventing it? Above all we want to know where the Russians are, for three weeks you have made our mouths water the way you never succeeded to with your pancakes. Tell us how they are breaking through the fronts, what tactics they are using, whether they are treating the prisoners like prisoners or like convicts, whether they are having a lot of trouble in the East with the Japanese, whether the Americans couldn't at least relieve them of that, since they are not invading Europe. And we'd also like to know about Kiepura's career, how he is getting along 
in America. A lot of news must have piled up in the meantime, OK, they won't broadcast a summary just for us, they have no idea how we suffered from the power failure, but one does find out a few things beside the very latest, please don't leave anything out, do you hear, not anything, please.

The one to be pitied is Jacob. A well equipped office is what he should have, a headquarters with three secretaries, or even better, five. A few liaison officers in all the important capitals, who would send every little piece of uncovered information to headquarters, punctually and reliably. And the secretaries would then sort out the details, their heads steaming, reading all the leading newspapers and listening to all the radio stations, and out of all that obtain the essence and present it to Jacob as the highest responsible person; then he could answer about one third of the questions truthfully, as truthfully as newspapers and radio stations and liaison officers ever do.

There's a newspaper sticking out of the "whistle's" pocket. The whistle comes out of the brick house, walks past the freight cars dragging his wooden leg behind him, right through the crowd of Jews who don't even notice what is limping past them, what do we care about newspapers, we've got Jacob. Only Jacob sees and cares, the magnifying glass in his eyes won't let go of the treasure in the railwayman's pocket, a little piece of paper with true or made-up reports of real happenings, in any case infinitely more valuable than a nothing of a radio. Relief for his exhausted ingenuity, should a daring exchange of ownership succeed. 
Behind the last track the whistle reaches his goal, a little wooden shed reserved for Germans only, that's what it says on the door, right underneath the little heart which they later carved into it, as, I guess, is their native custom.

Jacob doesn't let the loading with Kowalski distract him, always one eye on the shed, if the newspaper was still complete a minute ago, as it seemed to be, and if the railwayman is not woo wasteful, some of it will have to be left over. If the railwayman isn't a miser he should leave the rest behind. He mustn't be wasteful and he mustn't be miserly; there is no proof for or against, if an opportunity arises Jacob will go and get the rest. But whatever opportunity presents itself, it will always mean risking one's life, what business does a Jew have on a German toilet, for you, brothers, I am risking my head and my neck. I don't want to steal potatoes like Mischa, who is more practical-minded and thinks two times two, I will, if all goes well, swipe a few grams worth of news and change them into a ton of hope for all of you. If my mother had given birth to a bigger brain than mine, imaginative like Sholem Aleichem's, what am I saying, half of it would be enough and I wouldn't need such pilfering, I could dream up ten times as much and better stuff than they are able to write in their newspapers. But I can't, I can't, my mind is so blank that it scares me, I will do it for you people, for you and for me, I am doing it for myself too, because it is certain that I can't survive all alone, only with the rest of you. This is what a liar looks like from behind, I am going to go into their toilet and help myseif to whatever there is left, if only there is something left. 
The whistle finally reemerges into God's sunlight, takes a few deep breaths, lights a cigarette, for which he needs four matches in this wind, he takes enough time to make you want to throttle thim, but the all important pocket is empty. Let's see, what did that use to be like with newspapers, ours usually had eight pages, four sheets, let's assume his had four also, that would be the usual. You tear a sheet once and then once more and then a third time, per page that makes, just a moment, per page that makes eight pieces. You can tear them four times too, but then the pieces turn out pretty small, let's stick with three times, he certainly had enough paper. Four sheets times eight makes thirty-two pieces, no healthy person needs that much, one only tears up one page and the others one puts down to read. But even if he has torn them all, there'll be some left in any case, if he didn't in his ignorance throw the rest in too.

"What are you mumbling about all the time?" asks Kowalski. "Me, mumbling?" says Jacob.

"The whole time. Four plus sixteen makes this much and that much, what are you trying to figure out?"

The whistle finally disappears in the brick house again, Jacob takes a look at the guards, one is standing at the gate, bored, another is sitting on the running board of a freight car, reassuringly far away, the third is nowhere in sight, probably in the house or hiding out sleeping, since there is nothing going on anyway, and three is all there are.

"Keep working and don't look around at me," says Jacob.

"How come?" asks Kowalski. "What's the matter?"

"I am going to their toilet." 
Kowalski wears his surprised expression and doesn't keep working, the next thing you know this madman is going to go into the brick house for brandy and tobacco, he'll ask to borrow it from a guard, and they will no more put him to the wall for that than for what he is planning to do right now.

"Are you crazy? Can't you wait until the break and then go behind the fence?"

"No, I can't."

Jacob ducks and runs off like a pro, the stacks of crates provide cover from the glances out of the brick house almost all the way, except for the last few meters, but they are part of it too, they'll be conquered as well; Jacob closes the outhouse door behind him. Not one word about odors or graffiti on the walls, next to the eyeglasses is the bountiful loot. But first one more glance outside through the little heart, nobody noticed anything, the entire yard through a heart, it's the usual bustle out there. The loot consists of the expected remainder, he was not wasteful, quite a number of neatly creased and torn little pieces, just as though they had been cut with a knife, and underneath the pieces is a double page, completely intact. Jacob stuffs the pieces under his shirt, as smoothly as possible so they won't rustle while he works, better over his back than over his stomach. The double page isn't worth anything, that is, it's worth something, four times from top to bottom obituaries bordered in black, in itself quite gratifying but not too informative in content. Killed in action, killed in action, killed in action. We'll leave them there, we don't want to drag around any unnecessary weight, we'll memorize them easily enough, 
four pages of deaths, let the next visitor have his fun with those too. But let's not get too comfortable, as though we were on our own toilet, let's not let dangerously many minutes slip by, let's get back to work and breathlessly put this behind us, then we'll go into our unwatched room, unload and clean our back and play our new radio. And tomorrow you can all come again and ask questions for as long as the supply lasts.

Jacob looks out again to see if everything is still OK, nothing is OK, nothing at all, there's one mine after another all the way back, a soldier is approaching the outhouse, one might say: resolutely. His fingers are undoing his buckle, in his mind he is sitting already and beginning to feel better, no one could possibly manage to squeeze by him unnoticed, now what are you going to do? Jacob's knees painfully remind him of the fact that he is no longer a young man, easy as the way here was, one always notices these things too late. The door can't be bolted, some idiot tore off the eye to the hook, just try holding it shut, one push with his shoulder and he'll be inside, look at you in amazement and then do whatever else with you. Theoretically it's a matter of keeping cool, unruffled, the advantage of surprise is ours, and he still has a full eight steps. The boards by the back wall will mean at least five minutes and more than enough noise, now five more steps, you have no choice but the little oval hole, right into their crap. And you can't bring yourself to that, though you'd be skinny enough.

The soldier opens the door which offers no resistance, to his dismay he sees before him the opened double page of a newspaper, shaking moderately, which however is not noticed at this embarrassing moment. 
"Oh, excuse me!" he says, closing the door quickly and not seeing the decrepit Jewish shoes under the newspaper, nor the fact that the display of lowered pants, which would have rounded out this picture, was missing; for that, however, his head had not been cool enough and the time too short. Perhaps it was even lucky, too much disguise can be harmful too. The main thing is that he closes the door, free of suspicion, he settles down for a short period of waiting, his belt is already hanging over his forearm, and he walks back and forth, since that makes things easier to bear than just standing still.

How long a waiting period should Jacob settle down to, over the edge of the newspaper and through the little heart the grey figure is walking back and forth. Only a miracle can help now, let's have one then, one doesn't need to rack one's brain, for real miracles aren't predictable. There are two more minutes left (hardly any more) for the unexpected, and if it doesn't happen, which would only be just and fair, then one's proverbial last hour looks as ridiculous as this.

"Hurry up, buddy, I have diarrhea," one hears the soldier plead.

The little squares on one's back are beginning to feel sticky, they will have to be dried off before being used, if everything goes well as it does in fairy tales. And, Jacob tells me, suddenly he gets tired, suddenly fear and hope vanish, everthing gets strangely heavy and light at the same time, his legs, his eyelids, his hands from which four pages of soldiers killed in action for their country are gently slipping away.

"Did you hear that Marotzke is getting another furlough? Does that ever seem fishy! He must know some people high up there, don't you 
think? He takes off all the time, and we wait and wait and still have to stick around among these garlic eaters."

Good grief, garlic, if we only had one single clove spread paperthin on warm bread, you idiot, a Schultz or a Muller is being suspected on the toilet, one who bears no good will to a certain Marotzke, that part hit the target, whoever Marotzke is. Jacob leans against the back wall and closes his eyes, you can all wait a long time for a heroic rebellion, his is all over. Now it's his buddy's move out there, he'll have to keep the action going. Let him leave or stay, let him wrench open the door tormented by intestinal cramps, let him stare and shoot, his victim will not be surprised by it. Whatever comes after is his problem.

Who would guess that the miracle is already being worked on, it has been sketched out in rough draft. There is still Kowalski, Kowalski with two horrified eyes in his head, he knows what's up, he sees the situation. He sees the desperate soldier and the door still intact, he knows who is inside and who won't be liberated without his help, if he hasn't died from fright already. Liberation means distracting the German, not by throwing a pebble against the wall so he turns around to see who threw it, something must happen that will demand his immediate intervention. The first thing that comes to mind is the pile of crates, about two meters high and pretty wobbly. If two of the bottom crates are pulled away from under, then it will no longer stand as proudly and ready for shipment, that' 11 be the end of its precarious balance, and it might make for good distraction. But what happens to an idiot who is guilty of such clumsiness, what happens to Jacob if no clumsy person is 
to be found anywhere around, how much are forty years of friendship worth, arithmetic problems for Kowalski.

Jacob hears a soft rumbling in the distance, one can't shut one's ears as one can one's eyes, then he hears soldier's boots quickly running off. Reason enough to open your eyes again, surely this is what a miracle sounds like. His arms and legs regain their normal weight, here we go again. The air seems clear, that's what a glance through the heart seems to reveal, the Jews, who can be seen through the cutout, have interrupted their work and are all staring in a certain direction, probably at the place where the miracle is happening.

Kowalski has successfully undermined the pile of crates. He was just strong enough, one crate fell on his head. The soldier storms over from the outhouse and blindly into the trap, rushes up to the bait Kowalski, and one might say: hardly ever has a magician's trick been more successful. Even if the beatings are well aimed, the crate on the head was nothing by comparison, Kowalski whimpers softly, protects his face with his hands and profusely regrets his unpardonable blunder.

The rest of us stand there rooted to the spot gritting our teeth, someone beside me claims to have seen that Kowalski toppled the crate on purpose. The soldier keeps on beating, Marotzke is getting another furlough again and he isn't, maybe he is even sincerely outraged about that much clumsiness, but quite abruptly he stops his work. Something is stirring inside him, not pity and not exhaustion, but diarrhea is demanding its right, everyone can see that clearly. He grimaces and runs with long strides to the outhouse which meanwhile has been vacated especially for him. That is, first he calls: "And you'd better have 
all that stuff neatly piled up again by the time I get back over there, do you hear?" And then he performs his long strides, which, despite everything, look pretty funny. The matter can no longer be postponed, now he would certainly insist that any newspaper reader clear out immediately and without delay, for otherwise a small accident might well occur. But he can save himself the trouble, he tears open the door to an unoccupied toilet, the little accident has been avoided at the last moment.

None of us bystanders dare help or console Kowalski, this is a place for work not consolation. He wipes the blood off his face, checks his teeth which are all there but one, all things carefully considered it might have turned out much worse. The pain will pass, Jacob will remain, after the war we'll give him an exclusive WC on which he may sit for hours to his heart's content and think of his good friend Kowalski. Who should step around the remaining pile of crates but precisely the one who has just been saved by a miracle, coming up behind Kowalski's back, while Kowalski is still examining his bruises. Jacob gathers up the courage to stand before him, for Kowalski must not find out the real reason for this daring excursion. He is the one who most deserves not to be bothered with the reason, for him it must remain an incredible whim of Jacob's, which almost cost him his head.

"Thank you," says Jacob, moved. Moved really is the right word, moved for the first time in forty years, it isn't every day that someone saves your life, and on top of that someone whom you have known for so long and of whom, quite frankly, you wouldn't have expected it. 
Kowalski doesn't deem him worthy of as much as a glance, he gets up, groaning, and starts busying himself with the crates that had better be stacked up before the soldier returns from his troubles and checks to see how much his orders are worth. They would still be standing neatly in a row, as well as the few teeth left in his mouth, if Jacob was a normal person, if he hadn't given into irresponsibly odd yearnings, and others have to pay a bitter price for them.

Jacob's hands are flying, for each crate of Kowalski's there are three of his, which, as far as Kowalski is concerned, has to do with the question of guilt and also with anger and pain.

"Did you at least have a good shit?" Kowalski inquires, restraining his voice with difficulty. "Look at my face, look at it carefully, it must look beautiful! He didn't do that, you did. But why am I getting upset about it, the main thing is that you had a royal shit, everything else is irrelevant. But one thing I will swear to you, Heym, just try it again! Go ahead and try it and you'll see who'll help you!"

Jacob hides behind his work, Kowalski is right, from his own point of view. The one thing that could be said to calm him down Jacob can't say, and any other words would only make matters worse. Later, Kowalski, when all this is behind us, when the two of us are sitting quietly over a little glass of brandy, when the potato pancakes are sizzling in the pan, then I'll explain it all to you. In detail, Kowalski, you'll hear the whole truth, we'll laugh and shake our heads, crazy times those were. You'll ask me why I didn't tell it then, at least to you, my best friend, and I'll answer that I couldn't, because 
you would have told everyone else and they would have taken me for one of the thousand liars and rumor-mongers and would have been again without hope. And then you'll put your hand on my arm, because maybe you'll understand and you'll say: "Come on, old Jacob, let's have another vodka."

When the outhouse door is opened again after quite a long time, the pile of crates is proudly pointing to the sky, as though no one ever attempted to topple it. The soldier approaches at a leisurely pace, his hands behind his back, his uniform all buttoned, he is already being expected. Not exactly ardently, it's just that the task has finally been accomplished. But the way he comes up and stops and holds his head, his whole manner might be cause for alarm, for he looks friendly rather than critical. Somehow he sees the world with different eyes, how a few good minutes can change a person. The crates, he has completely forgotten the crates, he only looks at Kowalski's swollen face, which is still red, but on which hints of blue and green and purple can already be detected, and he seems concerned. To Jacob's eyes he seems concerned, figure that one out. He turns around silently and goes away, Jacob thinks: how lucky he didn't discover his soft heart until later, instead of being a good guy from the very beginning, otherwise he would never have run away from the door, he would have simply stood there, and a little later his goodness would have been put to much too hard a test.

In walking past, our soldier loses two cigarettes, Juno brand without filtertip. He loses them or drops them, a question that will never be clarified, nor will his motives, if indeed it was a matter of 
intention. In any case the cigarettes belong to Kowalski, after all, he is the one who paid for them.

Minutes later the whistle emerges from the brick house and tweets for the noon break. The railwayman, whom up to this hour none of us has ever heard talk and who nevertheless is the most talkative of all of our Germans, because a halfway usable radio fell out of his pocket. The "whistle" started it all today and it suspects nothing, just whistles for the daily soup and has no way of knowing how shamelessly its forgetfulness was exploited, or whatever it was. Only Jacob knows, he remembers the squares under his shirt and the double page, which has meanwhile come to an uncertain end and which one really should not leave so unused and forgotten.

"Have I already told you that the Germans are suffering tremendous losses?"

They are already standing in line, Kowalski turns around to face him and amidst his bruises the faint touch of a grateful smile of forgiveness begins to blossom.

The radio turns out to be of little value. Jacob puts one little square next to the other on his table, nine all together, and Piwowa and Rosenblatt refrain from any disturbance. Today they are what they have been for some time, namely dead from cat meat and a supervisor, today they are not meddling in Jacob's affairs, because he needs to concentrate on his puzzle game.

The name of the newspaper is not to be found, neither is the date, blind fate took care of that. The nine little pieces don't make up one 
single coherent page, because the whistle simply grabbed them at random without any regard to sequence, it's Jacob who has to work overtime. He tries and turns and fiddles and still can hardly find two matching seams. All that lies before him after all that effort are two extremely fragmentary pieces with holes the color of the tablecloth, two pages which look as though a prudent censor had cut out everything that is worth knowing and seen to it that only insignificant material would get into unauthorized hands. The sports section, for example, the sports section of all things is completely intact, how happy the Jews will be to find out that the air force boxing team beat a select marine group ten to six. Or that the Berlin soccer team once again didn't stand a chance against the Hamburg team, as so often in the past. Then the taciturn page reveals to us one more item of world importance, namely that a Gauleiter, whose name is torn off, remarked positively on some art exhibit, that His Excellency the Spanish ambassador would like to see friendly relations further extended, and that a trial before the People's Court against two agents paid by Jewish world finance came to its just conclusion.

And there you sit, looking disappointed, you hadn't expected much to begin with, only a downhill stretch for your poor brain, only a clue here and there out of which, with a little skill, one could prepare a feast, but you hadn't expected so little. Not a word about Bezanika, which the Russians must have left behind long ago, not a word indicating German difficulties, instead of that the numbskulls are playing soccer and having exhibits and nurturing justice. 
We at least want to be just, we want to leave open the possibility that the newspaper is old or that the best part was used by the whistle, but either way, one was an idiot to have had such high hopes. One should have known what to expect, if one had only taken five seconds to think about it. Everyone knows what kinds of newspapers they come out with, years ago there used to be a German paper in our district. The "Volkische Landbote," and don't ask me how good it was. None of us ever bought it, it's a sin to throw away money, but sometimes you get hold of it anyway, whether you wanted to or not. At the market they used to wrap fish in it, at the dentist's there was one lying around the waiting room, at the insurance company, of course, and sometimes in Kowalski's barber shop, because he wanted to look cosmopolitan. They used to say to him, Kowalski, they said, if you keep leaving that piece of crap lying around here much longer, you'll just ruin your business. Or do you think a German customer will stray into your shop so that your yiddish fingers can mess around in his Kaiser-Wilhelm beard? You'll have to leave that up to me, answered Kowalski, insulted, I don't tell you how much sawdust to mix into your potato pancakes either. That's the way Kowalski was and may my hands fall off this minute if that kind of slander is true. At any rate, one glance at that paper used to be enough to know what was what. They constantly felt threatened and humiliated and wronged by God and the whole world, it wasn't them humiliating us, but we them. The question of how much longer Germany was to suffer from the shameful consequences of that last war was rehashed in every edition, three times a week. And on the last page next to a rebus there were such incomprehensible poems, that one began to wonder if one had forgotten their language. 
Only the advertising section could have been worse, they had a knack for that. Every other Wednesday or Tuesday the two center pages were packed with little ads, and if one needed something that could only rarely or never be gotten at the market, like a couple of pretty chairs, wicker chairs maybe, or a modern floor lamp or a bigger set of plates because dishes never lasted long at the cafe, then a glance at the "Landbote" could do no harm. Of course one went by the name of the person offering his merchandise, if his name was Hagedorn or Leineweber one didn't even bother going there, if his name was Skrzypczak or Bartosiewicz, one might go, reluctantly, and if his name was Silberstreif one went. Because when it came to advertising, the people from the "Landbote" were not choosy, they let anyone, what mattered was that one could pay. But, as I said, that only went for ads, every other Wednesday or Tuesday, and the rest was pure trash.

One might have remembered all that before sticking one's head so pointlessly in the noose and only getting it back out through a miracle of friendship; that's how they wrote their newspapers in those days and that's still how they are writing them today, no one has taught them any better since. Only the talent for successful advertising sections seems to have stuck with them, the four pages that were left behind filled with announcements of men killed in combat indicate that there are still some men at work who understand their business.

Jacob turns over sheet after sheet, Poland hasn't completely surrendered yet, there is still an unread reverse page, which is as fragmentary as the front page, though perhaps not quite as taciturn. There is talk of a hero such as only our people produce, some pilot with 
a French name who shoots enemy airplanes out of African skies as though they were sparrows. The Fuhrer replied to a message from Il Duce, and in Munich a truck collided with a streetcar, causing a traffic jam of several hours. A cartoon. A tall man is holding a burning match over the head of a little man. Question: "What does that mean?" "Dover1 under fire." And a fat headline proclaiming victory on all fronts! One may believe this or not, we'd rather not, its bottom part is missing. It's a claim standing in mid-air, so to speak, and we know that they profess to have gotten almost as far as Moscow. They professed it, not us, but we've heard ourselves that there is fighting near Bezanika. There is quite a distance between those two, if you call that a victory you can have hundreds like that.

Fine, Jacob can figure out for himself that they are fibbing a bit, but what is he supposed to answer to the questions that will start pouring out over him first thing tomorrow morning? He had certainly imagined this to be much simpler than it was, he told me with a sigh. You read their propaganda dispatches, he had thought, you see through it without any or with only a little difficulty, you simply turn everything around, and the news items will start popping into your mouth, all you need to do is let them out at the right time. But now just try turning things around. The boxers of the air force didn't win against the navy but lost, the Gauleiter with the torn off name found the art exhibit horrible, the German hero didn't hit one single enemy plane in

1 Dover, or "Doofer" in the correct German spelling means "dunce." 
Africa, the street car in Munich cleverly dodged the truck, and the Fuhrer did not reply to the message of II Duce because he never got one. I'm telling you, all rubbish. Maybe the cartoon will reveal something, I think to myself, Dover under fire means that Dover is being shelled, Dover is in England if I'm not-mistaken, and if they're shelling England, England will shell them in all likelihood. Wonderful, they'll say to me tomorrow morning, so England is fighting back, but England is far away and what will happen to us? Unless one could change the victories on all fronts into defeats, but what do I know about fronts, where they are, how many there are, defeats have to be substantiated with details, I don't know any, what would you have done in my position?

Jacob makes an important decision. The power failure was a divine reprieve with the sole disadvantage that one had no influence over its duration. We'll create another such reprieve, but without that disadvantage, for the reprieve we have in mind has no end. When they ask us: what's new, Jacob, we'll let our shoulders droop and make our saddest face and whisper to them in a desperate voice: Imagine, my friends, last night I sit down in front of my radio with expectant ears and I turn the button the way I always do, but not a sound comes out! Not one! Do you understand, yesterday it was still chirping away like a bird and today it won't say one word. There is no point in lamenting, my friends, you all know how temperamental a radio can be, now it is broken!

The radio is broken. Jacob crumples up the little sheets, all nine of them into a small pile, his annoyance at not having had this 
glorious idea sooner doesn't overpower him. His joy of discovery is far greater, if the toilet paper served no other purpose than to enlighten him, then it was worth it despite everything, then the price Kowalski payed was not too high. Now one won't have to lie awake night after night with wide eyes, racking one's brain about what stories one might tell them the next day, now one will be able to lie there with open ears listening like all the others to whether far off in the distance the long awaited canon blasts aren't finally giving up their silence. The radio is broken, the sheets fly into the stove, Jacob will light them when heating becomes necessary, the damper is closed.

Just in time too, for a while ago in his haste Jacob had forgotten to lock the door, which is now opened, and in steps Lena, smiling, and without having knocked.

"Did you forget me today?" she asks.

"Of course not," says Jacob, gives her a kiss and locks the door even now. "I was just about to come up and see you, I was just finishing something first."

"What?"

"Nothing you absolutely have to know about. Did you eat your dinner yet?"

"Yes, everything you put out for me."

Lena looks around the room, she is not looking for anything in particular, only if it's tidy and if there is no dust. Her finger draws a line over the cupboard, is carefully inspected, the result is not overwhelming.

"Tomorrow I'll clean up your place," she says, "Today I don't feel like it any more." 
"No, you won't," says Jacob firmly. "The Professor said you are not to run around so much yet."

Lena says nothing, she sits down at the table, smiling, Jacob knows as well as she does that she will tidy up. For some time it's been clear who is in charge around here, that's no longer a topic for discussion, Jacob is to look after the meals, the clothing and the fuel in the winter, everything else is her responsibility, even if at times he still makes a bit of a fuss about it. It wasn't to argue over matters that have long been settled that she came in, and it wasn't because she feared he might have forgotten her, he wouldn't have done that, the reason for her appearance is a few days old, when she heard much and understood little, there is one thing she's rather unclear about.

"Have you heard what they are all talking about?" asks Lena. "What is it?"

"That the Russians will soon be here?"

"You don't say!"

Jacob goes to the cupboard, takes out his weekly ration, breaks off his supper and chews.

"Who is telling those things?"

"Well, Siegfried and Rafael and Frau Sonschein and Frau London, everybody. Don't you know anything yet?"

"No."

Jacob sits down across from her, sees her disappointed face, has promised himself clarity and knows of nothing. He divides his bread and holds half of it out to Lena as compensation. She takes it, chews too, but the bread isn't nearly as good as his ignorance is bad. 
"That is, I have heard something," says Jacob. "But nothing precise. What's so important about it?"

Her eyes are beginning to feel uncomfortable, how dumb does one think she is around here, as if she was a baby, she runs a household all by herself, they are talking of amazing things everywhere and what's so important about it?

"What will it be like when the Russkis are here?'

"How should I know?" says Jacob.

"Better or worse?"

Jacob feels like moaning. You managed to escape the hyenas at the yard for today, and if the idea about the broken radio works out forever, but already you have to look around for another path of escape, because within your own four walls a new tormentor is sprouting up, a beloved one to be sure, but it can ask more questions than you've got hair on your head. Or you don't look around, you accept your fate, a child of not even nine, surely you can handle that. You'll tell her, as best you can, something about the world of tomorrow, you are interested in that yourself, and if she knows roughly what's ahead, she won't be the worse for it.

"Will it be better or worse?"

"Better, of course," says Jacob.

"But how? What will be different?"

"We won't have to wear stars any more. Lena will be able to wear whatever she likes, and no one on the street will ask her where she left her star."

"Is that all?" 
"Oh no. You'll get plenty to eat...

"As much as I want?"

"As much as you want. Imagine, on the table there are all kinds of things, you take what you happen to feel like, and when you can't eat any more the table will be cleared and at the next meal everything will be there again."

"Now you are fibbing," she says, because it wouldn't be bad if he confirmed it one more time.

"That's the plain truth. And you'll have pretty dresses, we'll go to the store together and. ..."

"Wait a minute. What kinds of things will there be on the table?"

"Whatever you like to eat. Meat pate with butter and callah and hard-boiled eggs and fish, take your choice."

"Will you make potato pancakes again too?"

"I will."

"In the cafe?"

"In the cafe."

"You remember what you promised me, don't you? That I'll be allowed to help you in the cafe?"

"Sure."

"You'll stand behind the counter frying the pancakes and I'll be allowed to bring them to the customers in my white apron. And in the summer I'll bring them ice cream."

"That's how it 'll be."

"I'm looking forward to that already." 
Lena is looking forward already, whenever she is happy she pulls her shoulders up to her ears, Jacob finally gets a chance to eat, stale bread for now, until she wrinkles up her forehead after some thought, because she's suddenly run into an obstacle.

"But what about school? You also said that I would have to go to school later on. And if that's true, there won't be any time left for the cafe?"

"School is more important," Jacob decides. "During that time I'll serve the customers myself. When you are finished with school, you'll be able to help me, if you still feel like it then."

"But I would rather do it right away."

"What have you got against school? Did some idiot tell you something bad about it?"

She shakes her head.

"Well, then. School is something superwonderful. All kinds of dumb kids go in the door and all kinds of smart kids come back out again. But if you think I like you better dumb. .."

"Do Siegfried and Rafael have to go to school too?" "Sure."

After this reassurance there is a knock at the door. Lena jumps up, ready to go to the door and unlock it, but Jacob holds her back and puts his finger to his mouth. Knocking is always suspicious, not every suspicion is confirmed. It could be Kirschbaum, for example, wanting to talk about Lena's recovery, or the neighbor Horowitz wanting to borrow, on his word of honor, a spoonful of malt coffee until the next allocation, it could be a very ordinary knock, we'll find out in a moment, but 
even so, Lena doesn't need to be seen, she is nobody's business. Jacob puts his arm around her shoulder, pulls her to the window and points behind the bed.

"You crouch down there," he whispers. "And don't move until I call. Understand?"

Understood, Lena crouches down and doesn't move, and Jacob opens the door. Who would be standing there but Kowalski, with his swollen face he stands in the doorway, trying to smile.

"Well, you've got me on your neck again."

Jacob wouldn't mind getting rid of him while he is still standing in the doorway, what's up and then good bye, but Kowalski sure gives the impression of having all the time in the world. He walks past Jacob who is holding the doorknob, sits down at the table and says: "Don't you want to shut the door?"

Closing the door seems to be a noisy affair for Jacob, Lena is quiet as instructed, he has little choice but to sit down on the second chair, trying hard to look pressed for time.

"You are just having dinner," Kowalski remarks. "I am not disturbing you, am I?"

"Won't you just hurry up and tell me why you came?"

"Is that a way to greet a guest?" Kowalski asks in a friendly tone of voice.

"No, I'll go right down to get some wine from the cellar!"

"Why so tense? That's always been your trouble, Jacob, you didn't treat your customers nicely enough, they used to tell me that quite often while getting their hair cut. That's why fewer and fewer of them came to your place." 
"Thanks for the advice. But did you come to tell me that?" Behind the bed there is a soft giggle, audible only to one who knows that someone else is there.

"Believe it or not, Jacob, I have no particular reason. At home the walls are beginning to close in on me, you can't be in the same room night after night. Why not go and have a little chat with Jacob, I thought, he is probably feeling the same way, I thought, he'll be pleased. In the old days one used to get together after work too and everyone found that perfectly normal. Shouldn't one gradually start getting used to something normal again?"

Before Jacob could answer that the old days were the old days and that today is today, and he wants to be left alone and go to bed, because the work in the railroad yard is too much for him, Kowalski reaches into his pocket, takes out the two cigarettes, puts them on the table, one in front of himself and one in front of Jacob and thus plugs his mouth for the time being.

"That's nice of you," says Jacob. Maybe Kowalski thinks that he is referring to his visit after all, Jacob is staring at the cigarettes, or is he referring to both?

"Besides, you've told me mighty little today," says Kowalski after an appropriate pause. "What you said about the losses was pretty nice, I must admit, but you can imagine that other things don't interest me any less. And of those there hasn't yet been a single word."

"For heaven's sake, Kowalski, why do you torment me so? Aren't things difficult enough, do you have to start in on that every time? I 
can't listen to it any more! When I know something I'll tell you but can't you at least leve me in peace in my own room?"

Kowalski nods thoughtfully once or twice, he fidgets with his cigarette, puckers up his lower lip, the swollen one, he has come with a suspicion which seems to have some truth in it; he says: "Do you know, Jacob, I have noticed that you always get unfriendly, even tense, when I ask you for news. Of your own accord you never tell me anything, so I have to ask, and as soon as I ask, you get mad. I can't get that through my head, I don't understand the logic of it. Imagine it the other way around, Jacob, if I had the radio and you didn't have one, wouldn't you be asking me too?"

"Are you crazy? In front of the child!"

Jacob jumps up and turns towards the window, Lena has crouched and listened long enough, she emerges from her uncomfortable hiding place just as arranged, he did call her in a way, here whole face is beaming.

"Merciful God!" stammers Kowalski startled and claps his hands together, but no one is paying attention to him, this is between Jacob and Lena. They exchange glances, Lena winks, now you've put your foot in it, you weren't expecting this. Jacob says good bye to the slim hope that she might not have heard anything, everyone knows that children are often who knows where with their thoughts, or that at least she may not have understood, she is an alert little rascal, she is winking, and everything is perfectly clear. It'll require a good deal of thought until this new disaster has been repaired, every day there's a new one, so much for listening to cannon blasts in the night. But it isn't night yet, Lena is still standing there, facing you and enjoying 
her little triumph, which that old fool of a Kowalski has so casually prepared for her, one can't be rooted to the ground sweating blood and water forever, one will have to give some sign of life.

"Go upstairs now, Lena. I'11 come up to see you later," says Jacob faintly.

But first she walks up to him, pulls his head down, Jacob thinks it's for the kiss, which is part of even the briefest departure. But he can think whatever he likes, Lena doesn't feel like kisses, not now, she grips his head because it has ears on it, into one of them she whispers: "They all know it from you. You were fibbing after all!"

Then she is gone, Jacob and Kowalski are sitting at the table again, Kowalski is expecting a torrent of reproaches and feels totally innocent. Because nothing would have happened if Jacob hadn't hidden his child from him, from his best friend. And even if he hides her because he can't know who is knocking at the door, then he should have let her out as soon as he saw who had arrived. But no, he leaves her in her corner, he probably forgot about her, how can anyone forget a child, I ask you? After all, one isn't clairvoyant, and now he is mad and about to start in on his accusations.

"A fine job you did! It's not enough that the whole ghetto is already blabbing about it, now she knows about it too!" Jacob does in fact say.

"All right, I am sorry, there is no way I could have seen her. With that eye. .." 
Kowalski points to his eyes, Jacob can take his choice, they are both narrow as a Chinaman's, a powerful blue surrounds them quite effectively. Yes, Kowalski points to his eyes, a tactful reminder of a lifesaving that morning, one doesn't have to be any more explicit, if there are reproaches to be made around here, then the question is by whom to whom. Or let's both be a little generous and forget past incidents which can't be changed anyway. And it works. The eyes have a powerful effect, the mood at the table changes immediately, it warms up by a few degrees, the flame of Jacob's sympathy has been kindled, he moves a bit closer and carefully inspects what he has caused. "Doesn't look good."

Kowalski shrugs it off, it'll heal, eventually, if Jacob makes peace he won't hold any grudges either, he is in a generous mood. The unlit cigarettes are still lying there, Kowalski has thought of simply everything, even of matches. He pulls them out of his pocket as a last surprise, lights one against the worn surface, now let's have a smoke, brother. Come on, lean back too and close your eyes, let's not spoil this pleasure with talking, for just a few puffs let's dream our way back into those old times that are soon to begin again. Come on, let's think back of Chaim Baladusne with his thick nickel-plated glasses and his little store where we always used to buy our cigarettes, that is, the tobacco to roll them with. His store was closer to yours than mine and closer to mine than yours, it was exactly between our two, but in spite of that we never really warmed up to him, but that was his fault. Because he didn't go for potato pancakes and ice cream nor for haircuts and shaves. Many people said, he lets his hair grow so long out of 
piety, but I know better, it was out of stinginess, that's all. Oh well, who cares, you are not supposed to think badly of the dead, Balabusne always had a nice selection: cigars, pipes, cases with little flowers, cigarettes with gold filters for the rich, always wanting to persuade us to buy a more expensive brand, but we stuck with "Excelsior." And the stand with the little gas flame and the cigar cutter on his counter, the stand made of brass that he used to be polishing whenever you came into his store, one remembers that silly stand every time one thinks of the old days, even though one only bought tobacco once a week at the most and never used the stand.

"Are you thinking of Chaim Balabusne too?"

"What makes you think of Chaim Balabusne?"

"Nothing much, really. Perhaps the smoking."

"I am not thinking of anything."

The last puff has come, one more and you'll burn your lips. The smoke has done a wonderful job of irritating your lungs and of making your head giddy like after a few generous drinks, the world is slowly revolving around you in a circle, but one is sitting comfortably with one's hands on the table. A little sigh, a little moan, the smoke is still floating around the room, Kowalski says: "And now to the point, Jacob. What does it look like out there? What's new about the Russians?"

Jacob stays calm, it was just a question of time anyway, until Kowalski would start talking about the real reason for his visit, the cigarette couldn't fool anyone. Now there is no Lena crouching in the background any more, now one can talk openly, we've already figured out 
the answer for you and your kind, you'd better be ready for it. Well then, let's have that despairing expression, let's have those sadly drooping shoulders, here comes the last act in our question-and-answer play, Kowalski, you won't like it. But we won't let that deter us any longer, Kowalski, that's been taken into account for long enough already, after all, we too are nothing but poor tormented humans.

"I wasn't going to tell you this..."

"They're being pushed back!" screams Kowalski.

"No, no, it's not that bad."

"What then? Speak up already!"

"Imagine," says Jacob softly and flawlessly saddened, "a while ago I sit down by my radio and turn the button, the way I always do, but not a single sound comes out. Do you understand, yesterday it was still playing, no problem, and today it will not say a word. There's nothing that can be done about it, my friend, a radio is a strange thing, and now it is broken."

"Good God!" Kowalski shouts horrified, for the second time this evening Kowalski shouts "Good God!" and even claps his hands together again, probably because he can't do one without the other.

"It would be nice to have something to smoke," says Jacob yearningly, for it is the following day, the cigarette, Juno without filtertip, is just a memory now. He is standing on a freight car doing a kind of "yontef" work, as one might well call it, he is grabbing sacks that were so kindly presented to us Jews for hauling. We bring him the backbreaking sacks over a stretch of fifty or even more meters, 
all he has to do is hoist them up to the side of the freight car and stack them up neatly, as you can see mere recreational work, especially since there are two of them. Jacob and Leonard Schmidt.

The day, by the way, began with amazement on our part; when they showed us what was to be done today, we looked at each other in surprise and thought, they don't know what they want. Because a good two weeks ago a whole train of cement bags arrived, as if they were planning to build houses, we unloaded them piece by piece, and covered them with tarpaulins, and today all of a sudden they tell us that the sacks are to go back on the train cars. That's their business, we obediently load the sacks back on the train cars, just as they wish, we drag them to the cars and on one of them stands Jacob doing yontef work and saying "it would be nice to have something to smoke," and Schmidt answers, almost amused: "If that's all you have to worry about, Mr. Heym."

Leonard Schmidt. He found himself in this ghetto like the virgin finds herself with child, it snuck up on him in ways he would never have dreamt were his. For Schmidt has lived a life that might well have merited a continuation on the other side of the fence, his sojourn in our midst is for him one of the few incomprehensible matters of this world. Born in 1895 in Brandenburg-on-the-Havel to a wealthy father and a mother loyal to her Kaiser, he attended a first-rate gymnasium in Berlin, where his father had moved for business reasons, (acquisition of a textile factory), two years after Leonard's birth, and immediately after his graduation he became a soldier. Attack on Flanders, Verdun, occupatin of the Crimea, and later Champagne, when things were looking bad; that's how Schmidt made war. Then he was discharged from the 
army in all honor as a proud lieutenant and decorated with badges for bravery before the enemy and whatever else, and then he turned to the pursuit of a career. University studies were in order, as is proper for upper-class sons, the study of law at Heidelberg and the final semesters in Berlin. His success could not have been better, all exams were passed with flying colors, most of them even with honors. Three unavoidable years of apprenticeship went by, then the visiting card: "Leonard Schmidt, LLB," and finally the big moment, the opening of his own law firm in the best part of town. Good clients were not long in coming, in fact his father's connections steered them to him, soon he had to hire two young lawyers for the less important cases, and he made a name for himself ten times faster than many another. Marriage made in heaven, two medium-blond beautiful daughters, the world respectfully tipped its hat to him every day, until someone from the Bar Association, driven by envy, hit on the disastrous idea of searching out his family tree, of sawing away at it and letting everything come to a nasty end. The wife, two daughters and the bank account could still be sent off to Switzerland because good friends had warned Schmidt, he himself didn't make it. He was still busy with the settlement of the most important matters, when there was an emphatic knock at his door. In Schmidt's head the whole thing rattles around as an idiotic joke, maybe we'll wake up some morning and the clients will be sitting in the waiting room again, he was well on his way to becoming a German nationalist. But they didn't let him, they knocked on his door and told him to make no fuss, horrified expression on the maid's face amongst the plush chairs covered with white linen, they brought him here because his great-grand- 
father attended the synagogue and his parents were dumb enough to have him circumcized, they themselves weren't too sure why any more. Joke or no joke, his share of suffering is double or triple, during the first few days when he was still here, right after he finished his life story, he asked me miserably: "Can you understand that?"

And a short time later, one might have thought, (if one bothered about him very much at all) that he is gradually getting used to ghetto life, he arrives at the freight yard in an outfit which makes our hearts stand still with surprise. On the left side of his chest is a clip with a little thing hanging down, black and white, which, upon closer examination, turns out to be an Iron Cross. "Use your head!" someone says to him. "Take that cross off and hide it. They'll shoot you down like a mad dog for that!" But Schmidt turns away from him and starts working as though nothing was the matter. We all make a big detour around him, no one wants to be dragged into this, there is nothing to be done for him, yet even from our safe distance we don't let him out of our sight. A whole hour later a guard finally notices the monstrosity, gulps a few times, stands silently in front of Schmidt, and Schmidt stands deathly pale in front of him. After an eternity the guard makes an about-face, pivoting on his heel, it is beginning to look as though he's been struck dumb, he goes into the brick house, comes right back with his superior and points to Schmidt, who is the only one working again. The superior beckons Schmidt to him with his finger, no one would place a bet on his crazy head any more, the superior bends down over the clip, looks at the thing carefully, like a watch-maker stooped over a tiny damaged part. 
"Where did you get that?" he asks.

"Verdun," says Schmidt in a shaky voice.

"That won't do around here. That's forbidden here," says the superior. He takes the decoration from Schmidt's chest, puts it in his pocket, takes down no name, shoots down no evil-doer. Treats the whole incident like a pleasant change that will give rise to general hilarity tht evening in the pub. He cheerfully returns to the brick house, the guard is watching over other things again, not another word about it, Schmidt has had his fun and we our entertainment. That's how he acquired a unique kind of fame after his arrival, so much for Leonard Schmidt's resume.

"In my whole life I've never had anything to do with law courts," says Jacob.

"Oh," says Schmidt.

They are taking it easy, each neatly grabbing one of the sacks which we carriers lay down for them at the edge of the car, and lifting it with an "Up she goes!" on to the right spot. Not even the rain bothers them, since their freight car is covered. In the little breaks that arise now and then, they lean against the side, wipe the sweat off their foreheads, which has accumulated there in some mysterious way, and they chat as in peacetime. Whenever Kowalski or the Schtamms or Misha unload their sack, panting and eyeing them enviously and telling them with a sneer to take good care of themselves and not to work themselves to death, they smile. "Don't you go worrying about us."

"That is, I was a witness once." "Oh." 
"But not in court. Only in the office of the district attorney who was in charge of the case."

"What case?"

"It was a matter of whether Kowalski owed money to Porfir the money-lender. Porfir had miraculously lost the IOU and I only had to testify that Kowalski had given him back the money."

"Were you present?" asks Schmidt.

"Not at all. But Kowalski had explained it to me ahead of time, word for word."

"But if you weren't present and therefore only knew the situation from hearsay you should never have been a witness. How did you think you knew for sure that Kowalski had in fact given the money back to this gentleman? It could have been, I don't want to imply it, but it's at least conceivable, that Kowalski might have lied to you to get you to testify in his favor."

"I don't believe that," says Jacob, without thinking about it for very long at all. "He has many faults, nobody knows them as well as I do, but he is not a liar. He told me right off the bat that he hadn't given the money back to Porfir. Where was he supposed to get it?"

"And even though you knew that, you testified before the district attorney that he had returned it in your presence?"

"Yes, naturally."

"That isn't as natural as that, Mr. Heym," says Schmidt, amused. You can bet that he is beginning to wonder about the remarkable concept of justice of this peculiar people he is supposed to belong to. 
"Anyway, it helped quite a bit," Jacob says at the end of his story. "The cutthroat Porfir didn't succeed in his suit. His money was gone, but what am I saying, his money! He skinned almost every one of us small businessmen. Thirty percent interest, can you imgaine that? The whole street rejoiced as Porfir and Kowalski stepped out of the courthouse after the verdict, Porfir boiling with anger and Kowalski beaming like the sun."

At the edge of the freight car Kowalski with his multicolored eyes drops his sack on the ground, with half an ear he caught something, Kowalski beaming like the sun, he asks: "What kinds of stories are you telling about me?"

"The thing about Porfir's lost IOU that time."

"Don't believe a word of his," says Kowalski to Schmidt. "He badmouths me wherever he goes."

Kowalski trots back to the next sack, wet as a poodle, after throwing Jacob a what's-that-for glance. Schmidt and Jacob, who are all dry, start exerting themselves a bit too, without chatting for a change, how many sacks can fit onto one single freight car? Until the next little interruption, until something important occurs to Schmidt, until he asks: "Don't mind my nosiness, Mr. Heym, but what does Sir Winston have to say about the present situation?"

"Who?"

"Churchill? The British prime minister?"

"No idea what he has to say. Haven't you heard yet? My radio is broken."

"Don't make any jokes!" 
"What do you take me for?" says Jacob seriously.

Schmidt seems taken aback, Jacob notes, just like the others today, from whom one couldn't keep that secret first thing in the morning, with drooping shoulders and despair in one's voice, the only news of the day. Schmidt, the somewhat haughty Schmidt, whom a jokester had nicknamed Leonard Assimilinski, seems to feel touched to the core like everyone, all of a sudden he is not one whit different from them. "How did it happen?" he asks softly.

The answer to that had been slightly modified that morning, there wasn't time to present it to each one like one had to Kowalski, all gift-wrapped, Jacob had to decide upon considerable deletions. How did it happen? "Well, how do you think? The way a radio simply quits. Yesterday it was still playing, and today it isn't any more."

Reactions were mixed, some cursed an unjust God, others prayed to $\mathrm{Him}$, one tried to console oneself with the fact that radio and Russians are two completely different things, one man wept like a child, the tears ran down his cheeks unnoticed amongst the raindrops. Someone said. "I hope that isn't a bad omen."

Jacob couldn't say yes or no, he had to leave them to their little grief, better to that than to the whole truth. He can't say any consoling words into Schmidt's droopy ears either, his supply of consolation is exhausted. Let's please remember every once in a while, just for a few minutes, that Jacob is just as much in need of consolation as all the poor wretches around him, just as cut off from any supply of news, that he is tormented by the same hopes. It's just that a crazy coincidence changed an equal into someone special and to 
this day has kept him from laying his cards on the table. But only to this day, today I am letting you peek into my sleeve, you have seen how empty it is, no ace of trumps is in there any more. Now we are all equally clever, nothing distinguishes us, nothing but your belief that at one time I was someone special.

"There is nothing for it, Mr. Schmidt, we'll have to go on. Up she goes!"

Across the yard an unfamiliar voice hollers through the softly falling rain. "Hands off there!"

Jacob and Schmidt run to the door and see what is happening out there, the twin Herschel Schtamm is standing on the siding near a perfectly ordinary freight car, which is still closed up. He must have thought that it is to be loaded next, and when he hears the unfamiliar voice that can only be meant for him he quickly pulls his hand away from the bolt lever which he was just going to push up. The only remarkable thing about the incident so $f a r$ is the voice, which, however, is very remarkable indeed, it belongs to the "whistle," therefore unfamiliar. The whistle in the railwayman's uniform walks as fast as its wooden leg permits towards 'Herschel Schtamm, who backs away in fright, the whistle stops by the freight car, examines the bolt, it's still in place.

"Weren't you listening a while ago? This car is not to be touched, dammit!"

"Yes," says Herschel Schtamm.

Then the whistle turns to all the Jews who have stopped working and are enjoying the excitement of what has never before been heard, with a loud voice it turns to them: "Did you all get that, you 
fleabags? This car is not to be touched. Next time there' 11 be trouble!"

So that's what his voice sounds like, I would say not too successful a debut, I would say a weak baritone, one might have wished for a more pleasant timbre. The whistle strides back into the brick house with dignity, Herschel Schtamm loses no time in picking up his work, in order to get out of the limelight, the rest of us do too, the incident, which didn't really amount to anything, has, for the time being, come to an end.

"What kind of a freight car might that have been?" Schmidt asks.

"How should I know?" says Jacob.

"Mr. Schtamm is lucky he didn't get it. The guard did in fact tell us this morning not to have anything to do with that freight car. Surely you heard it too?"

"Yeah, yeah."

"Then why does he go over there?"

"Good grief, how should I know that!"

Schmidt has no feeling for when a conversation is over, he volunteers a few opinions about the usefulness of strict adherence to orders, about the increase in chances of survival resulting from such obedience, he formulates a short lecture on the status quo of the legal situation that happens to be in force as a result of the present government situation. Jacob is only half listening. Quite frankly, Schmidt is not especially one's cup of tea, he considers himself, without ever explicitly saying so, better and smarter and more cultivated, he probably wouldn't have had any complaints about the 
ghetto if they hadn't thrown him, of all people, into it as well. When he tries hard to minimize the differences (and that's what he does most of the time) one can't rid oneself of the impression that he is faking it, look how nice of me, I am simply acting as though we were the same. The differences are there, he can't overcome them, just the way he looks at you or talks or eats or speaks of the Germans or of old times, but above all the way he thinks. You can't be choosy about your comrades in misery, and miserable he is without a doubt, he trembles no differenty over his portion of life, that is, just a little bit differently, in his special way, which isn't quite so pleasant to our sort.

Soon Herschel Schtamm comes dragging a sack, his soaking wet fur cap on his head, under which he hides his piety, Jacob asks him: "What was the matter, Herschel?"

"You won't believe this, I heard voices in the freight car," says Herschel.

"Voices?'

"Voices," says Herschel. "As true as I am standing here, human voices."

He may well feel a shudder running down his spine, he especially, since he is always much too hot under the fur cap, he blows up his cheeks and nods a few times sorrowfully, you can imagine what that means. Jacob sure can, he accompanies Herschel's recital with helpless sighing, with closing of eyes and raising of eyebrows, they are having a little wordless dialogue, and Schmidt just stands there not understanding a word. 
Mischa comes by, he unloads his cement sack, Mischa says softly: "You've got to keep working, the guard is already looking at you." Jacob suddenly has two left hands, the sack slips away from him, Schmidt says, annoyed: "Will you watch it?"

Jacob has to watch it; he feels, he recalls later, like one who has just been dreaming of happiness and cozy corners, when someone comes up and pulls the warm blanket away from you, and you lie there naked and trembling with disenchantment.

"You are so quiet?" says Schmidt after a while.

Jacob continues to be quiet, imperturbably saddened he takes the sacks, only a sly glance towards the inconspicuous freight car on the siding, behind those walls human voices have been heard. Air holes right under the roof, no one is tall enough to be able to peek out of them, and no one is screaming, not from inside and not from outside, why isn't anyone screaming, the sacks must be neatly stacked. There it is. Standing reddish brown on the siding, as though forgotten, but they won't forget it, in some ways you can count on them. Yesterday it wasn't there yet, tomorrow it will be gone again, only a short stopover on its way somewhere. One just like it has been loaded a hundred times, and unloaded, loaded and unloaded, crates, coal, potatoes, under strict supervision, machines, rocks, freight cars exactly like that one, but this one is not to be touched or there' 11 be trouble.

"Do you think it's true?"

"That what's true?"

"About the voices?" 
"Don't ask such questions. Do you think Herschel Schtamm is trying to show off?"

"But who could be in the car?"

"Who do you think?"

Schmidt's mouth falls open, a horrible suspicion suddenly takes hold of him, he gasps: "You mean. .."

"Yes, I mean!"

"You mean, they're still sending more to the camps?"

That's the way it is, unfortunately, Schmidt doesn't understand the game of allusions, how certain things aren't mentioned and yet said, he will never understand it, deep down he'll always be a stranger. For him everything has to be broadly and clearly spelled out.

"No, they're not sending anyone any more! The war has been over for a long time, we could all go home if we wanted to, we just don't want to, because we are having such fun here!" says Jacob rolling his eyes. "Are they still sending some? Do you think there aren't any left? I am still here, you are still here, we're all still here. And don't everyone start thinking for a moment that it's as good as over!" Schmidt interrupts the well-deserved lecture with a quick motion of his hand. He points outside in horror and calls: "Look at that! Schtamm!"

Herschel had never attracted attention, except for all that praying that time, which he believes led to the power failure, now he is making up for it, he is standing on the siding by the freight car. As yet the guards have not noticed him, Herschel is pressing his ear to the side of the car and talking, I can see clearly how he moves his lips, 
how he listens, then talks again, pious Herschel. His brother Roman happens to be standing next to me, eyes like millwheels, he is about to run to Herschel to bring him back before it's too late. Two men have to hold him back by force, and one of them has to whisper: "Stay calm, you idiot, you'll just draw their attention to him!"

I can't hear what Herschel is saying and what those inside are telling him, the distance is much too great for that, but I can imagine, and it isn't just a case of vague assumptions. The longer I think about $i t$, the clearer I know his words, even if he has never confirmed them.

"Hello! Do you hear me?" says Herschel first of all.

"We hear you," a voice from inside the freight car must have answered. "Who are you?"

"I am from the ghetto," Herschell says then. "You have to hold out, you'll have to hold out just for a short while longer. The Russians are already past Bezanika!"

"How do you know that?" they ask from inside, everything quite logical and obvious.

"You can believe me. We're keeping a radio hidden. I have to go back now."

Those who are locked in thank him uncomprehendingly, a little white dove has strayed over to them in the darkenss, their words are immaterial, maybe they wish him happiness and riches and one hundred and twenty years of life, until they hear his footsteps departing.

Everyone is staring at Herschel, who is starting to turn back, brainless as we are, we just stand there gawking, instead of continuing to work and pretending that everything is as it should be. First we 
prevent Roman from committing a big blunder, then we commit it ourselves, maybe Herschel wouldn't have escaped anyhow, who can know about that afterwards, in any case we aren't doing anything to divert their attention from him. Not until this moment does he seem to discover fear, up to this point everything just happened all by itself, as though in accordance with unfathomable laws, which even sleepwalkers must obey. His cover is more than sparse, as good as non-existent, Herschel knows well why he is scared. A pile of crates, another empty freight car, otherwise nothing in his path, though he really is in need of protective cover. I see him sticking his head out around the corner of the car, centimeter by centimeter, with his eyes he is already with us, I can hear him talk about a trip around the world, the opposition is still quiet. The guard at the gate is standing with his back toward the freight yard, not a sound arouses his attention, the two others have disappeared, presumably into the house, where the rain has driven them. I see Herschel making his final preparations for the big sprint, I see him praying. Even though he is still standing near the freight car moving his lips, one can easily see that he is not talking to those inside, but to his God. And then I turn my head towards the brick house, it has a small attic window which is open, on the window sill is a rifle that is being aimed in utter calm. The man behind it can't be made out, it is too dark in the room, all I see are two hands adjusting the direction of the barrel, until they are satisfied, then stopping, as in a painting. What should I have done, I who have never been a hero, what should I have done if I was one, perhaps yell, but what good would that have done? I do not ye11, I close my eyes, an eternity passes, 
Roman says to me: "What are you closing your eyes for? Look, he'll make it, that crazy guy!"

I don't know why, I think of Chana at that moment, whom they shot in front of a tree, the name of which I do not know, I am still thinking of her after the shot, until everyone around me starts talking all at once. Only one hollow shot, the two hands had, as I mentioned, lots of time to prepare everything carefully during all of Herschel's prayer. It sounds strange, I have never heard one single shot, only several at a time, like a naughty child stamping its foot in anger, or a balloon is blown up too hard and pops, or even, since I am revelling in metaphors, God coughed, God coughed in Herschel's face.

Those locked in behind the reddish brown freight car walls might ask: "Hey, what happened?"

Herschel is lying on his stomach between two railroad ties, right across the track. His clenched right hand has fallen into a black puddle, his face, of which right now I can only see one half, looks surprised to me, with the one open eye. We stand silently around him, they allow us this small break, Roman bends down over him, pulls him off the track and turns him over on his back. Then he takes off his fur cap, his fingers have trouble unbuttoning the flaps under the chin. He puts the cap into his pocket and goes off. For the first time in this freight yard Herschel's earlocks are allowed to blow freely in the wind, many of us have never seen them before, only know them from hearsay, so that's what Herschel Schtamm really looks like, without masquerade. For the last time: his face, framed in black from wet earth and much hair, someone has closed his eyes. I am not about to lie, what's the point, 
he wasn't a beauty, he was very pious, wanted to promote hope and died of it.

The guard at the gate has come up behind us, unnoticed, it's about time to turn our thoughts to other things, he says: "Enough of that gawking, or haven't you ever seen a dead man before? Hurry up and get back to work, quick, quick!"

We'll take him with us after work and bury him, that's allowed without being specifically written down in one of the many regulations, that has simply become customary. I look back up at the window which has been closed again, no more rifle, no hands, nor do any of them come out of the house, they aren't bothering about us any longer, for them the whole affair is over and done with.

Life goes on, Schmidt and Jacob busy themselves with the sacks again. Schmidt had understood enough to keep quiet now and to keep to himself why Herschel simply had to run to the freight car, even though the railwayman had expressly and definitely warned them a while ago.

In Jacob's head self-reproaches are welling up, one knows all too well which role one had in this play. You fabricate some measly consolation for yourself, you imagine some large scales, with two pans, on one of them you put Herschel, in the other you pile up all the hope you have spread amongst the people in the course of time, on which side will it go down? The difficulty is, you don't know how much hope weighs, no one will tell you, you'll have to find the formula for yourself and complete the calculation all alone. But you calculate in vain, difficulties keep piling up, here is another one, who is to reveal to you what disaster has been prevented through your inventions? Ten catastrophes or twenty 
or even a single one, whatever has been prevented will remain eternally hidden from you, only what you caused is visible, there it is, lying by the track in the rain.

Even later, at noon, one hasn't come a bit closer to solving the problem of the many unknowns, Jacob is off by himself spooning up his soup, today everyone is leaving everyone else alone. He stayed out of Roman Schtamm's way, Roman didn't look for him, only by the handcart on which the tin bowls are placed after use do they suddenly stand opposite one another. They look each other in the eye, especially Roman, Jacob tells me: "He looked at me as though I had shot his brother."

The hours after work belong to Lena.

A long time ago Jacob stopped in the hallway with her, in front of his door and said: "Now pay close attention, in case something happens, so that you'll find the key to my room," he said. "Here behind the doorframe is a little hole in the wall, see that? This is where I'll put the key, then the rock goes back in front of it. You can remove it very easily, if you stand on your tiptoes you'll be tall enough. Try it." Lena tried it, she stretched, removed the rock, grabbed the key with one last effort and proudly held it out to Jacob. "Wonderful," said Jacob, "make sure you remember the spot. I don't really know why myself, but maybe it'll be important some day. And one more thing, don't tell anyone about it."

By now Lena doesn't have to stand on tiptoes any more, for two years she's been tirelessly growing in the direction of the little hole behind the doorframe. If anything happens, Jacob said, well today 
something is happening, Lena gets the key, unlocks the door and stands in the empty room, not daring to breathe. She is a bit scared, but that'll pass, if Jacob comes in unexpectedly, she'1l just tell him that she is tidying up. The intentions that drove her here are risky, he would hardly approve of them, but what he doesn't know won't hurt him.

Two obstacles are in her way, she doesn't kid herself about that, the first one is the hiding place, which, for the time being, is unknown, the second one is, she doesn't know what a radio looks like. There isn't an unlimited number of hiding places in the room, within a few minutes it can be turned all upside down, the second obstacle seems much harder. Jacob has explained everything possible, she could, for example describe a bus without faltering, even though she has never seen one face to face, she could talk bananas, airplanes, bears that start growling when one turns them over on their backs. During the power failure that time, Jacob even led her on the mysterious path that light covers, from the coal mine to the little lamp under the ceiling, but never one word about a radio. One does have a few meagre clues: Everyone is talking about it, its possession is forbidden, it reveals things to you that you didn't know before, it is so small that one can easily hide it.

"Will you show me your radio tomorrow?" she asked him last night when he came to see her in the attic after Kowalski's unsuccessful visit.

$$
\begin{aligned}
& \text { "No," he said. } \\
& \text { "And the day after tomorrow?" }
\end{aligned}
$$


"Not then, either."

"And the day after the day after tomorrow?"

"I said no. That's enough of that."

Even her irresistable fluttering of eyes had no effect, Jacob didn't even glance at her, so she tried one more run at it after a heavy pause: "Will you ever show it to me at all?"

"No."

"And why not?"

"Because."

"Will you at least tell me what it looks like?" she asked next, her plan already half worked out in her head. But he refused an answer to that too, and so her half-plan changed into a whole one.

In short, Lena has to look for something of which she knows nothing more than that Jacob is keeping it hidden, a thing without color, without form or weight, luckily Jacob couldn't have that many unfamiliar things in the room. The first thing she finds that she has never seen before, must, according to all human calculation, bear the name radio.

Lena starts with the obvious hiding places, under the bed, on top of the cupboard, in the desk drawer. Possibly a radio is so big that it doesn't even fit into a drawer, maybe anyone watching would laugh out loud about Lena's looking for a radio there. But it isn't her fault that Jacob is so stubbornly uncommunicative about it, and anyhow, no one is watching. It's not in the drawer, there is nothing in there, under the bed and on top of the cupboard there is only dust. That leaves the inside of the cupboard, otherwise there is no hiding place, 
it has two doors, one above, one below. One could skip the one above, behind it are the four plates, two deep ones and two flat ones, the two cups, one of which Lena dropped when doing the dishes, breaking off its handle, then a knife and two spoons, the always empty sugar bowl, and the food lies behind it, if there is any. Lena feels quite at home behind this door, she often sets the table, brings in the food and clears things away, one could skip that one, but the undertaking must not fail because of a careless oversight. She checks: the four plates, two cups, sugar bowl, knife and spoon, and also a piece of bread and a bag of beans, no surprises.

Well then, the cupboard door below. Lena hesitates, her fingers are already holding the key and can't quite decide; if what she is looking for isn't in there, then it's nowhere. In that cupboard down below she'd never had any business before, "my stuff is in there," Jacob had said, that sounded utterly harmless. His stuff, no one knows what's behind two such innocent words.

Her hesitation has limits, Lena finally opens it up, there are footsteps walking past outside in the hallway. Locking up won't do, if Jacob came in he wouldn't ask what she is doing here, he would ask why she locked herself in, and there is no answer to that. Lena clears things out, pants and shirt, needle and thread, a pot, why isn't it up above, a box with nails and screws, an empty picture frame, the book on Africa. She treats herself to a short break, the book has more to offer than just letters, which Jacob has been so strangely concerned about lately, the pictures deserve a few moments of attention, in spite of everything. The woman with the amazingly long breasts that are so flat and look as though they'd been dried and with the ring right through 
her nose, the point of which Jacob will explain later. The naked men that have painted their faces all over, holding long spears in their hands, and on their heads huge shapes made of feathers, hair and ribbons. Or the skinny children with bellies round as balls, animals with horns and stripes, and endless noses and even longer necks, all that can well capture your interest, but not quite enough to make you forget your real goal.

Lena crawls into the cupboard up to her stomach, a last obstacle is removed, a modest pile of laundry with a green towel on top, and then. The path has been cleared to this never seen object, proud smile of victory, it is standing inconspicuously back in the corner, looking secret and forbidden. She brings it out into the light, a small delicate grid, a little screw, all glass and round, she places it reverently on the table, now let's savor this! His stuff, Jacob had said, minutes pass in staring at it, what will one find out that one didn't know before? Does this thing talk like an ordinary human being, or does it reveal its secrets in a different way, somehow magically? After an experimental silence Lena realizes: all by itself it won't reveal anything, one has to get it to speak, maybe one just has to ask it something. If that's it, let's hope it's not by way of a certain magic word like Ali Baba in front of Sesame.

"What's my name?" Lena begins with the simplest, but the thing already seems overtaxed by that. Lena gives it lots of time, no use, her disappointment loses its edge in the thought that one must ask it something unfamiliar, something one didn't know before, and she does know her name. She asks: "How much is thirty times two million?" 
Since even this time there is no answer, she attempts new ways, she thinks of the light one can turn on and off at will, possibly this thing can be turned on in the same way, let's try the little screw. It's all rusty, it can barely be turned, after a lot of effort only a soft squeak, and her fingers are already hurting. Then Jacob stands in the door and asks, as anticipated: "What are you doing here?"

"I", says Lena, "I wanted to," she says, one has to recover from one's shock, "I wanted to tidy up your place. Don't you remember?" Jacob remembers, he looks at the Sodom and Gomorrah in front of the cupboard, back at Lena who wanted to tidy up, before he even opens his mouth she knows that it won't be that awful. "But I hope you aren't finished yet?" says Jacob.

Of course she's not finished yet, she just started, she jumps up and stuffs pot and book and laundry back into the cupboard, his eyes have trouble following her. The picture frame next, the nails fall out of the box in her hurry, they're quickly picked up, then needle and thread, where are the needle and thread, we'll find them next time, the door flies shut, and the mess is already forgotten. Only the thing stays on the table, he's seen it anyway, there is his only secret, and he is still taking his time about getting mad.

"You're not mad at me, are you?"

"No, no."

Jacob takes off his jacket, washes his hands from the freight yard, Lena begins to get restless, and the thing just stands there being ignored.

"And what did you really want here?" 
"Nothing. I tidied up," she says, knowing that it makes no sense. "What were you looking for?"

Now his voice is getting louder, but the question is really too dumb, he is already sitting in front of the thing, asking hypocritically what one was looking for, we'll just plain refuse the obvious answer.

"What is the lantern doing here?"

"What lantern?"

"This one! Do you see any other?"

As Lena becomes silent and her eyes grow large, staring at the so-called lantern, and as her large eyes gradualy fill with tears, Jacob pulls her close to him and asks much more gently: "What's wrong?"

"Nothing."

He sets her on his knee, she rarely cries, actually, who is to know what goes on in such a little head that broods on its own all day long. "Come on, tell me what is wrong. Does it have something to do with the lantern?"

"No."

"Have you ever seen it before?"

"No."

"Do you want me to explain to you how it works?"

Lena holds back her tears, after all, it's not Jacob's fault that she made a mistake, and anyway, tomorrow is another day, the hiding place that she overlooked today will turn up somehow. She fixes up her eyes and nose with her sleeve, it's not big enough, Jacob's handkerchief rushes to her rescue.

"Do you want me to explain it to you?" 
"Yes."

"Look. This thing is a kerosene lantern. In the old days there were only these kinds of lanterns, before one knew about electric light. One pours the kerosene in here, into this little bowl. This here is the wick, it soaks it all up, and only its tip peeks out. You can make it longer or shorter with this screw here. You light the wick and then the room gets bright."

"Can't you do it just once?"

"Unfortunately I have no kerosene."

Lena gets down from Jacob's knee, she takes the lantern in both hands, examines it from all sides, so that's why one was kept waiting and waiting for an answer. At home, at the Nuriel's, a long time ago, there was no kerosene lamp and no radio, mistakes occur for lack of experience, she puts the thing back into the cupboard after one last 1ook. Order has now been restored, even for Lena, she even sees a funny side to the failure in her voyage of discovery.

"Do you know what I thought?"

"We11?"

"But you mustn't laugh at me?"

"Why would I?"

"I thought that was your radio."

Jacob smiles, he remembers that as a tiny little boy he took a hunchbacked old neighbor lady for a witch, a similar mistake, but soon his smile gets weaker and weaker. Lena is looking for the radio, you can't deny that, it would have been a good idea to have left her to her belief, what difference does it make to a lantern to be taken for a 
radio? He would have sworn her to sacred silence, now you've found it at last, now you know what it looks like, not another word about it now, especially not to strangers. And for weeks there would have been peace, at least at home. But the chance has been ruined, Lena didn't reveal herself until it was too late, and one didn't have enough presence of mind to size up the situation in the room and the lamp on the table and the meaning of her tears. Soon she'll ask: OK, so that was a lamp, but where is the radio? Soon or maybe in an hour, tomorrow at the latest, she is alredy dancing from one foot to the other. The fact that it's broken won't appease her, then just show me the broken one, and unfortunately one isn't one of those who can answer a troublesome question with a slap in the face once in a blue moon. There is one more possibility, a very simple one, Jacob could claim that he had burned it, a broken radiio, if found, is no less dangerous than a whole one. He could say that, that would be the end of his radio, for Lena and for the whole world, but the last day at the freight yard plays a certain role here. The dead Herschel Schramm, his brother Roman with his tormenting looks, the locked up strangers on the siding, all of them have something to say too, before the radio is forever destroyed. And the individual Jews who arrived full of hope with their questions early in the morning and departed in dismay, without the news to which they have a right. They'll probably be home by now, relatives and acquaintances are knocking at their doors, what was the news at the freight yard? Nothing, they'll hear, the radio doesn't tell anything any more, it is broken, yesterday it was still playing, and today not a sound from it. The relatives and acquaintances leave again, spreading 
the latest news in all houses and streets, which soon begin to look just as miserable as before the evening when a spotlight fixed Jacob around 7:30 on the Kurlandischen. There is a lot to be considered before reckless decisions are arrived at, before one buys the peace of mind that turns out to be no peace at all.

"Will you show me the radio now?"

"I already told you no yesterday. Do you think anything has changed since then?"

"I'll find it anyway." says Lena.

"Then keep looking."

"Do you want to bet that I'll find it?"

She switches to an overt attack, let her look rather than ask questions, the next radio she finds, Jacob will not talk her out of. And the radio that she'll never find will be spared the fire for the time being, many reasons are responsible for that, but above all Herschel, the curly haired; already that morning, lying in the rain between the railroad ties, he has practically fixed it.

Jacob goes off to work with a light heart, whoever notices his composure and his jaunty stride and makes comparisons with yesterday or with the last few days, will be struck by the change; now that's a well-balanced man. With a light heart, for the hours in bed were rich in weighty decisions, the connection to the outside world has been reestablished. The radio played half the night, right after Lena had been gotten rid of it came on and it played until sleep suddenly arrived, but by that time one message or another had already drifted 
into one's ear, and none of it to be scoffed at either. With a light heart, for the little flame of expectation shall not be extinguished, that's Jacob's decision; half the night he searched for twigs, wood and tinder to nourish it. He succeeded in making a respectable leap forward, he and the Russians, he quietly let them win a big battle on account of their superior equipment, near the little river Rudna, which doesn't exactly tumble by your front door but is delightfully much closer than the city of Bezanika.

In reviewing the news reports he had circulated so far, Jacob noticed that, all things considered, they had simply consisted of long drawn-out nothings, aside from the very first one about Bezanika, nothing substantial at all. Out of every idea he had made a huge story, often incredible and transparent, so far doubts have failed to pop up only because hope has made them blind and stupid. But during the night, before the battle at the Rudna, an insight was gained, Jacob finally saw the source of his difficulties. In other words, as soon as the light was turned off, it dawned on him why ideas were so slow in coming and had lately not been coming to him at all. He was too modest, he suspected, he had always tried to confine his news reports to areas that could not be verified later on, when life has returned to its normal course. With every piece of news he had been constrained by his timidity, by a bad conscience somehow, the lies had escaped his lips haltingly and reluctantly, as though they were looking for a hiding place to quickly crawl into before someone examined them more closely. But this procedure was fundamentally wrong, that's what became clear 
last night, a liar with pangs of conscience will always remain a bungler. In this line reserve and false modesty are uncalled for, you have to let the cup overflow, conviction should be written all over your face, you must act out for them what someone should look like who already knows what they are about to find out. You have to throw around names and dates, let the battle at the Rudna only be a modest start. It will never make its place in history, but in our story it will hold a place of honor. And when everything has been endured, when anyone interested can read about the true course of the war in books, then let them come and ask: "Hey, what kind of nonsense were you telling in those days? When was there ever a battle at the Rudna?" "Wasn't there?" one will answer in amazement. "Let's see that book. . .That's right, there never was one. It's not in here. I must have misunderstood at the time, please forgive me." They'll probably forgive you, at worst they'll shrug their shoulders, maybe some of them will even thank you for the error.

Jacob has, as far as the progress report on the battle is concerned, done a little preparation ahead of time, and his knowledge of geography has come in very handy. The battle at the Rudna and all its consequences should suffice for the next three days, let's not go overboard. Because the crossing of the river is not entirely without difficulties, we're not going to make it that easy for the Russians, the Germans have blown up the only bridge, Jacob decided. Before the advance can be continued a makeshift pontoon bridge must be built, and that takes three or four days. Then that's finished and the Russians march towards the little town of Tobolin, of which the Germans have made 
a kind of fortress. It again holds out for three days, it is surrounded, heavily shelled by artillery and stormed by the infantry, in a hopeless situation Major Karthauser (a splendid name, with rank to match), signs the capitulation document, Tobolin is liberated. Quite incidentally, Mischa will be happy about that, he has an aunt living there, let's hope she lived to experience this victory. Aunt Leah Malamut owned a custome jewelry shop when Mischa was still a boy, and, for each of his birthdays she used to send a little box of colorful buttons and ribbons. But let's not dwell longer than necesary on Tobolin, it's a long way from there to the market town of Pry, the next one in our direction. About seventy kilometers, they have already been roughly sketched out, but not yet completed in all detail. That'll be Jacob's evening job for the next while, up until Tobolin all is clear for the time being, and today at the freight yard the results of the glorious battle at the Rudna will be announced.

With a light heart Jacob goes to work, a brilliant little idea occurs to him which he could tack on to the events at the Rudna. Couldn't perhaps some secret German plans have fallen into the hands of the Russians through which all the opponent's activities on this front are known for weeks in advance and therefore made ineffective? That would be a plum in Jacob's cake, but immediately there are doubts concerning its likelihood, for does one keep secret plans in such an unsure place, after all the Germans are no idiots. And the Russians are no idiots either, even if they captured plans of such sort, they wouldn't trumpet it out into the world by way of radio, they would keep it nice and quiet and take measures in complete secrecy. So let's forego the 
brilliant little idea, what we have is good enough to give the Jews a little bit of that composure with which Jacob is still going off to work, with a light heart.

At the corner of Tismenizer Street he sees Kowalski waiting; nothing unusual in itself, Kowalski often waits for him here, he lives here. In approaching it becomes clear that Kowalski is not alone, beside him stands a young man; now that is a little more unusual, especially since one has never seen that young man before.

Already from af ar Kowalski points to Jacob with his finger, the young stranger follows the finger with his eyes, as if Kowalski wanted to explain to him, it's that one over there, the one in the grey jacket.

Jacob catches up to them, everyone shakes hands and all three continue on their way, the formal introduction has yet to be made. Kowalski says: "You are late today. We've been waiting for you for quite a while."

"Did we by any chance have a date?" Jacob asks. He looks at the young man who is not saying a word, from the side he gives the impression of being somewhat helpless and embarrassed, he is staring straight ahead, even a blind man can see that his presence means something. Kowalski said: "We waited," therefore the young man isn't there just by coincidence, Kowalski is in this game, he must have asked him to come.

"Aren't you going to introduce us?" says Jacob. "You don't know each other?" Kowalski acts amazed. "This is Josef Najsdorf ."

"My name is Jacob Heym." 
"I know," says the timid young man whose name is Najsdorf; his first words, and they don't really tell you anything at all. "You don't work in the freight yard?" asks Jacob. "No."

"But rather?"

"In the tool factory."

"But then you are walking the wrong way. You should be walking in just the opposite direction."

"We start later than you," says Najsdorf, and one can tell that he feels uncomfortable with his explanation.

"I see. And since you still have a little time, you're just walking along with us to the freight yard. Naturally."

Najsdorf suddenly stops the way one stops before running away, he gives the impression of being upset, he says softly to Kowalski: "Couldn't it be done without me, really? I don't want to have anything to do with this whole business, see. I am scared, see."

"Don't start in on that again. Haven't I explained everything to you from beginning to end?" Kowalski says, nervously taking him by the arm before he can desert him. "Just get it through your head! He won't tell, I won't tell and you won't tell either. Besides the three of us, not a soul will find out about it. What could happen?"

Najsdorf still looks quite unhappy, but he stays, even after Kowalski carefully lets go of his arm.

"What won't I tell about?" asks Jacob, who would really like to find out more now. Kowalski motions him to wait with a gesture of his hand, the gesture means many things, it means: don't you see what state 
the boy is in, we'll just have to leave him alone for a moment, so that he can get hold of himself and of his fright. Kowalski is good at meaningful gestures like that. He winks encouragingly at Najsdorf, which isn't so easy with his swollen eyes, he is saying: "Now you can tell him what you are."

Najsdorf is still hesitating, Jacob is more than a bit curious: a surprise early in the morning that scares a young man and about which one has to keep quiet, even if as yet for unknown reasons, it's not every day Kowalski manages something like that.

"I am actually a radio mechanic," Najsdorf finally says in a strained way.

So he is a radio mechanic.

There isn't a chair around for Jacob, looks are darting back and forth, happy ones and scathing ones, a pointless rage at Kowalski makes breathing difficult for Jacob. He is playing the good Lord, this idiot of a friend, he is worrying about repairs of whose extent he hasn't the faintest notion and he probably even thinks one ought to be grateful to him for his initiative and his trouble. Because it probably wasn't easy to drum up someone who is knowledgeable about radios in just one single short evening that ends at eight o'clock already, but not too hard for a friend like Kowalski. Stands there beaming expectantly, how did I do that, magnificently, of course, one more helpful act of the kind and one could hang oneself right then and there. And for his sake the battle at the Rudna was won, one is tempted to burn the radio after all. Right after saying goodbye yesterday he must have run off and driven the whole ghetto crazy. He didn't know Najsdorf before, one would have known 
about that, Kowalski's acquaintances are unfortunately one's own as well. He must have crawled from one to the other and asked amiably in his penetrating voice: "Don't you by any chance know someone who can fix a radio?" "A radio? What in heaven's name do you need someone who repairs radios for?" "Well, why do you think?"

Someone then sicked him on this poor Najsdorf who has more sense in his baby finger than Kowalski does in his whole head, his fear is the best proof. Told him who knows what, to calm him down, dragged him over here, set up the most embarrassing situation you can imagine, and now there you are face to face with a live radio mechanic.

"You certainly have a lovely job!" says Jacob. "Don't I, though."

Kowalski is as happy as a lark, there's simply no end to his friendly services, the other day the miraculous rescue from the toilet, today the second feat, let anyone try and top that, and all that at a time where there is so little room for favors. But he isn't expecting enormous gratitude, these things are taken for granted amongst true friends, action is what counts here, not talk. And since time is running short and since Jacob still shows no visible signs of joy or understanding, Kowalski explains to him: "Because he is supposed to fix your radio. And don't worry, the kid is reliable."

"That's nice to know."

"Of course I can't guarantee anything," says Najsdorf modestly and willingly. "If for example a tube is burned out, there is nothing I can do about it. I don't have any spare parts, I told Mr. Kowalski that right away." 
"Go and look at it first," says Kowalski.

Jacob has to find a way out in a hurry, one would think it gets easier each time, since practice makes perfect, but in fact it never does. Reluctantly he recalls last night's resolutions, they are more easily conceived than carried out when obstacles like this emerge, but Jacob regains control. Happy news goes with happy faces, of course, but Jacob can't make one, the sight of the furiously helpful Kowalski stifles all smiles. Jacob painfully manages a broad grin and forces his eyes into an expression of determined friendliness, he is trying to act as though something terribly important has just occurred to him.

"You couldn't have known about this yet," he says. "You've gone through all this trouble for nothing. The radio is working again."

"No kidding!"

"But it was nice of you just the same."

"How did it happen? Did you fix it yourself?" asks Kowalski, and one doesn't know if he is honestly glad or if he is disappointed because his helpfulness has lost its point.

"It's working again. Isn't that good enough for you?"

"But how?" asks Kowalski. "A radio doesn't fix itself!"

If Najsdorf wasn't with them Jacob could tell anything, a tube was loose, or he banged it hard a few times with his fist and it started to play again, Kowalski knows just as little about radios as he does. But unfortunately this Najsdorf is still there with his expertise, he doesn't only look relieved because his help is not needed after all, there is a professional involvement in his eyes as well. And now try and dream up a good explanation that will satisfy both a simpleton and 
an expert, surely you know how you fixed your radio, hurry up and report it and do it with a happy face.

"It was only the lead-in wire. I simply shortened it a bit." Everything turned out well, Jacob is even a little proud of himself, all three parties are satisfied. Najsdorf shakes hands and says goodbye, thanks again for all his trouble, he walks in the direction of the tool factory and no longer needs to be afraid.

Kowalski and Jacob continue on their way to the freight yard, Jacob is plotting revenge for a ruined morning which had started out so well. And so the battle at the Rudna is kept secret from Kowalski, let others bring him the joyous message. Such agonizing battles won in sleepless nights are wasted on friends who never pass up an opportunity to torture you to death. Even if what Kowalski did today was done without evil intentions, the difficultuies are taking on scary dimensions, one simply can't just sit around and watch this continue. Only two days ago he got Lena to pester you, today it was Najsdorf, of all the questions his are the most persistent, surely keeping this one single battle from him is an appropriate form of revenge.

"Was there any news last night?" asks Kowalski.

"Nothing."

A few acquaintances say hello, this is the only street leading to the freight yard and it is gradually crowding up. Jacob notices them looking at him intently, Kowalski too it seems, he is basking a little bit in Jacob's glory and whispers to someone: "The radio is working again." 
As if he had any part in it, and the other man hastens his steps and whispers it to others, soon many are turning around to Jacob and are looking better than yesterday. Jacob nods impreceptibly, it's true, you've heard it correctly, and the repaired radio will probably reach the freight yard before its owner.

"What I wanted to ask you about," says Kowalski, "I've been thinking that it really is about time to start worrying about other things too."

"For example?"

"For example about business."

"About business? What kind of business?"

"I am a businessman," says Kowalski. "Isn't now the best time to prepare everything for later, at least mentally?"

"What do you mean: businessman? And what do you want to prepare? Isn't your barber shop standing there waiting for you?"

"That is the question. You know, I've ben wondering for a long time whether I should do something different afterwards."

"Something different at your age?"

"Why not? Just between you and me, I've hidden away a bit of money. Not really a fortune, mind you, but couldn't one invest it in something better than my old shop, which I was never very fond of? And neither were you, if you are quite honest. And if I am going to do something like that, I want to be sure that it isn't just thrown away."

"And what is my part in this?"

"Every so of ten they broadcast business reports over the radio, don't they?" 
"They do."

"Hasn't there been anything by which one might be guided? Any helpful hints?"

"I am not interested in those things."

"Sure you are not intereted in those things! You must have heard something."

"What is it you really want to know? I have no idea what you are getting at."

"I simply want to know which line of business has the best prospects."

"Sometimes I think you are getting childish, Kowalski. Do you seriously believe they are going to announce over the radio: We recommend that after the war you invest your money in such and such a business?"

Kowalski sees that, he says: "All right, then I'll ask you as a friend. If you had money, where would you most want to invest it?"

So Jacob thinks about it, such an investment must be carefully thought about, where would he most want to invest it? "Maybe in luxury businesses? If you remember, after the last war everyone was after them like crazy. And David Gealje, whom you know too, built himself a magnificent house out of liquor."

"I know, I know," says Kowalski, "but where are the raw materials going to come from? Do you think there'll be enough potatoes at first to make liquor from?"

"That's the wrong way of looking at it. There won't be any raw 
materials for anything at all. For postwar business you don't need logic, all you need is a good nose."

Kowalski keeps on doubting, one can see he has no nose for liquor, he's not going to waste his money on that.

"Textiles ought to have a pretty good chance. One always needs clothing," he says.

"Maybe you are right. For years they've made nothing but soldier's clothing. Soldiers' pants, soldiers' socks, soldiers' jackets, soldiers' coats, ordinary people had to wear out their old clothes. And what does that mean?"

"Wel1?"

"There' 11 be a demand."

"That's only half the truth, Jacob. Don't forget that during that same time many clothes have been lying around closets unused, the clothes of all the soldiers. And today they are still like new.

"Hm," says Jacob thoughtfully.

And so on, they consider two or three other possibilities, Kowalski even toys with the idea of getting together with Jacob and setting up a large-scale restaurant with all the trimmings. But for Jacob that's too big a venture and Kowalski probably isn't that serious about it anyway, Jacob comes back to his original suggestion: that Kowalski should stay in his old shop, and if he doesn't know what to do with the little bit of money hidden away, then he can renovate, go and get yourself some new chairs. Because regardless of demand, hair and beards are going to keep on growing. And when they arrive at the freight yard Kowalski is almost back to being a barber. 
Lena wins the bet because Jacob can't keep holding his own in this uneven match, he shows her the radio.

After a few days of fruitless searching nothing was left that wasn't already familiar to her, so she resorted to begging. She can beg like no one, and she knows particularly well how to beg Jacob, with flattery, tears, being hurt in a very special way, tears again, and all that with amazing persistence. Jacob held out for a few days, then his strength runs out, one easily predictable evening Lena wins her bet.

For me, probably the only one to still be alive and able to think about these things, this evening is the most incredible one in the whole story. Even when Jacob had explained it to me as best he could, I didn't quite understand it, I asked Jacob: "Didn't you go a little far? She could have betrayed you and that would have been the end of it all?" "No, no," Jacob answered, smiling, "Lena would never betray me." I said: "I mean without any intention. Children are quick to let a word slip out without thinking, someone picks it up and proceeds to make a mountain of it." "Lena thinks very carefully about what she says," Jacob answered, and I had to believe him. But there was still something else that seemed hard for me to understand. "There is still something else, Jacob. How could you be sure that she wasn't catching on to it all? How easily she could have realized what was really going on, she is a smart girl, as you say. Wasn't it awfully lucky that she didn't catch on?" "She did catch on," Jacob said and his eyes glowed with pride. "You know, I didn't really care if she noticed anything or not. I just wanted to make her happy without any regard to consequences, that's why I went down to the basement with her." And after a pause 
that was much too short for me to comprehend that evening, he added: "Well, no, I did care. I think that time I wanted her to find out everything. I had to show my radio to someone, and of all people Lena was my top choice, with her it was like a game. All the others would have been horrified about the truth, she was happy about it afterwards. That's why on that evening I said to her, come on down in the basement, let's listen to the radio together." And all of a sudden I found myself smiling and I said: "If I had known at that time all the things you can do, I would have come to you and asked you to show me a tree." Which Jacob in turn could not understand.

Let's listen to that evening.

Considerable suspense, Lena is hanging on to Jacob's coat, the basement hallway is long and dark. The metal doors, which they pass on tiptoes, are all closed, as if there were riches of inestimable value hidden behind. The air is cold and damp, despite August outside. In his concerned foresight Jacob had insisted on a winter dress, stockings and a scarf for Lena, little drops are hanging on the ceiling and the walls, glittering like weak little lights.

"Aren't you scared?"

"No," she whispers decisively, and that isn't even too much of a lie, her curiosity is probably making her forget everything else. After all, at the end of this corridor the thing is waiting, which for days has been the object of her search and which had already been given up for lost, and now she is supposed to say, I am afraid, let's turn back? Finally Jacob stops, almost at the last door in this long row, he takes the key out of his pocket, unlocks, turns on the light which is hardly brighter than no light at all. 
The basement must be described, four meters square and no windows. Most noticeable, a wall cut diagonally across the room, almost dividing it in two, leaving a narrow hallway between; the builders had planned it for coal storage. A quick inventory: an iron bedstead with a rusted red boxspring, a little pile of stove debris with pieces of tile, green ones and brown ones, and several pipes with elbows. And in the corner next to the door the only treasure worth locking up, a carefully stacked little pile of wood, in which the greedy poacher Piwowa used to lie months ago when the logs still provided a place to sleep. And now a glance behind the partition: more stove debris, bricks and a spade and bucket with holes and an axe. That's it, I am being so particular, not that all these objects are of significance, but because I was there later in my search for witnesses and traces and nonexistent trees. Just as I measured the distance between the police station and the nearest corner with my tape measure and went to Jacob's room, in which meanwhile a single old woman was living who knew nothing of the fate of any previous tenants (the housing department had assigned the room to her for the time being), so I also visited the basement. This cellar room still came with the room upstairs, Mrs. Domnik handed me the key without too many questions, she only said that she had never gone downstairs yet, she didn't own any stuff that needed to go in the basement, and so I shouldn't be surprised at the dust and likely mess, it wasn't her fault. And dusty it was indeed, and cobwebs all over, that's the truth, but I didn't notice any mess, I found everything just as Jacob had described it to me. The iron bed, stove debris, axe and bucket, even the logs were still lying by the door. 
Jacob locks up from inside, Jacob says: "So no one will bother us." Then he says: "And now sit down here," and points to the iron bed.

Lena has already looked around a bit, so far with no success, nevertheless she sits down without any objection, he could put her obedience to a much higher test under these circumstances.

"Where do you keep the radio?"

"Hold your horses!"

He crouches in front of her, takes Lena's chin in one hand, turns her face towards himself so that not a single glance goes astray, and starts with the most urgent preparations: "Listen very carefully to what I am telling you. First of all you must promise me that you'll be good and do everything I am going to ask of you. Sacred word of honor?"

The sacred word of honor, instituted for very important occasions only, is impatiently given, her eyes demand that he not waste so much time with introductions.

"You are going to sit here very quietly. The radio is behind this wall here. I'll go back there now, I'll turn it on, then it'll play, and we will both hear it. But if I hear you stand up, I'll turn it off immediately."

"Can't I see it?"

"No way!" says Jacob decisively. "And actually you are not supposed to listen to it while you are still so little, it is strictly prohibited. But I will make an exception in your case. OK?" 
What can she do, she is being coerced and has to cooperate. Listening is better than nothing, even if she had looked forward to seeing it with her own eyes. And anyway, she always could, she could. .., well, we shall see.

"What does your radio play?"

"I can't know that ahead of time. I have to turn it on first." All preparations have been concluded, one can't do more for one's own safety, Jacob gets up. Goes to the wall, stops at the passageway and looks once more at Lena with an expression that is supposed to chain her to the bedstead, then he disappears for good.

First Jacob's eyes have to get used to the new light, it hardly extends beyond the partition, he bumps against the old bucket with his foot.

"Was that the radio already?"

"No, not yet. It'll be another moment."

Something to sit on will be needed, this business may take a while once it gets rolling, Jacob turns the bucket upside down and makes himself comfortable on it. Very belatedly he runs into the problem of the program the radio has to offer, Lena had already touched on it, and the time is ripe for an answer. One should have thought about it earlier, how many things one should have done, maybe even practiced up a bit, but now the radio has to play just as it is. Making music, talking, Jacob remembers that ages ago his father used to be able to imitate an entire brass band with tuba, trumpets, trombone and bass drum, it sounded hilarious, after dinner, if the day had passed without too many problems one could sometimes twist his arm. But will such an 
orchestra work right off the bat, his father polished it for a long time, Lena is quietly waiting in her winter dress and Jacob is already sweating, even though the performance hasn't even begun yet. "It's starting," says Jacob, ready for whatever comes out.

A fingernail clicks against the bucket, that's how you turn on a radio, then the air is filled with humming and whistling. The warming-up period is omitted, these details are for experts, Jacob's radio has the right temperature from the start, the choice of station poses no problem. An announcer with a high voice, as I said: whatever comes out, begins: "Good evening, ladies and gentlemen from near and far, you are now about to hear an interview with the English Prime Minister, Sir Winston Churchill." The announcer then hands over the microphone, a man in a medium voice-range is heard, the reporter: "Good evening, Sir Winston."

Then Sir Winston personally, in a very low voice and with a distinctly foreign accent: "Good evening, everyone."

Reporter: "I warmly welcome you to our studio. And now let's get right to our first question: Would you kindly tell our listeners how you assess the present situation from your own point of view?"

Sir Winston: "That is not very difficult. I am firmly convinced that this whole mess will soon be over, at the very most a few more weeks."

Reporter: "And may I ask where you get this marvellous certainty?"

Sir Winston (somewhat embarrassed): "Well yes, on all fronts there is good progress. It is beginning to look as though the Germans will not be able to hold out much longer." 
Reporter: "Wonderful. And how are things going around Bezanika in particular?"

A little accident occurs, his sweating and the cold air in the basement, or else something got into Jacob's nose, in any case: reporter, announcer and Sir Winston all have to sneeze at the same time.

Reporter (the first to recover): "Bless you, Sir Winston!"

Sir Winston (after blowing his nose): "Thank you. But back to your question. Around Bezanika things are looking especialy bad for the Germans. The Russians are beating them right and left, Bezanika was captured long ago. Just yesterday they won an important battle at the river Rudna, if you know where that is."

Reporter: "Yes, I know that river."

Sir Winston: "Then you also know where the front is now. It will certainly not last much longer."

Reporter (exceedingly happy): "Our listeners will be very pleased, unless, of course, they happen to be Germans. Sir Winston thank you very much for the enlightening interview."

Sir Winston: "My pleasure."

Announcer (after a short pause): "That, ladies and gentlemen, concludes our scheduled interview with the English Prime Minister, Sir Winston Chruchill. Good bye."

A fingernail clicks against the bucket, that's how you turn off a radio, Jacob wipes the sweat off his brow. A bit thin, the interview, he thinks, and a bit over Lena's head too, but one isn't (and that will unfortunately never change) exactly a Scholem Aleichem in inventiveness, don't ask too much of a poor devil, let's hope it will do for today. 
Jacob reappears, it turns out not only around Bezanika are things going beautifully, but even right here in the basement, Lena has finally heard a radio with her own ears, strictly prohibited for children, and she is delighted. It could have turned out otherwise, masking one's voice meant a step onto new territory, and in three different ways at that, Lena might have frostily requested that he stop this nonsense right now and finally turn on the radio. That would have been a blow for Jacob, just the thought of it, but she wouldn't dream of such words, everything is just as it should be, he can see that right away.

"Did you like it?"

"Yes."

Mutual satisfaction. Jacob is standing in front of her and is about to talk of leaving, we've all had our fun, our beds are waiting, but Lena says: "It isn't over yet, is it?"

"What else?"

"I want to hear more."

"No, no, that's all," he says, but he is just saying it. A short verbal duel, it is getting late, Lena wants to hear more, maybe another time, never satisfied, just turn the radio back on, she'll be happy with anything. Jacob sneezes again, tonight the whole world has the sneezes, while blowing his nose he examines her expression and finds no suspicion, that tips the scales.

"What do you want to hear?"

So Jacob sits on the pail once again, in complete silence, more and more overwhelmed by ambition. Ambition concerning the brass band which won't leave him alone even though it's been silent for a good 
forty years and is covered with dust and the instruments are all rusty, Jacob is feeling daring, today is a day for action.

The familiar click to start out with, then humming and whistling, it's already sounding better the second time around, and then very suddenly it starts, the music, with drum and cymbals playing the opening part. Drum and cymbals are followed by a solitary trombone which needs several notes to get on the right track. The melody is uncertain, Jacob says, an improvised series of notes interspersed with a variety of familiar tunes, but in no logical sequence, the only thing you can tell for certain is that it's a march. His feet timidly take over the percussion, aided by his fingers which make use of the pail, thereby freeing his mouth for the rest of the instruments. Because one single trombone doesn't produce a brass band, the trumpet has to take over, then the falsetto clarinette and here and there an occasional tuba blast, from the very back of his throat. Jacob loses, as they say, all inhibition, there is only one constraint he submits to, despite his hurry there is a certain rule he recalls, strictly followed by his father a long time ago: vowels are to be used sparingly, to be avoided if possible. For instruments are most easily mimicked by certain consonants, or more exactly by sounds resembling but not entirely matching consonants. Therefore a simple "da de dum" or "la la la" will not escape his lips, sound will have to be formed that exist in no alphabet, the whole basement reverberates with new creations. Quite possibly too much of an effort for a child like Lena, who would even be satisfied with something less polished; but remember, ambition has a part in this, this test is self-inflicted, and anyway, perfection is 
most easily attained with no outside pressures. Soon the tune is easily held, trumpet and trombone begin their dialogue, then practice alternating and become more and more successful in bringing it to a happy conclusion. The clarinette finds itself pushed into the background, too high a register, while the tuba makes itself heard more frequently, even daring to show off from time to time with a little melody al its own, a series of lower notes, taking refuge, as it begins to run short of breath, in two or three measures' worth of pail banging.

In a phrase, a little bit of music history is being written, Jacob is basking in his glory, Lena is growing restless on her bedstead. Very quietly she gets up, all sacred words of honor have been forgotten, her legs obediently sneak up to the partition. She has to see the thing that sound so much like Jacob and yet so different, that can speak in various voices, sneezes like him, and makes such strange noises. Just one quick look, even at the price of being caught in a breach of promise, there is nothing one can do about legs that have their own strong will. And actually there is no need for all that caution, the din coming from the thing drowns out everything else, nevertheless she tiptoes up quietly. Up to the passageway, the trombone is concluding a skillful solo and is letting the trumpet take over, Lena carefully peeks around the corner. Invisible to Jacob, who is not only sitting sideways but also closing his eyes, a sign of highest mental concentration; he is lost in a world of sound that has rules known to him alone. No, Jacob does not notice that he is sitting there naked and bare for a few moments, later on he will become suspicious through Lena's mysterious allusions, and not until much later will she tell him to his face what 
really went on in that basement. For now a few seconds of staring and marvelling will do, Lena set out for India and discovered America, the aim of her excursion was to see this thing and now she has seen all she needs to, it looks exactly like Jacob. There is only one question left to ask, she will want to know if aside from this radio he has another one, he likely doesn't, where would he keep it hidden if not here. Lena knows what no one else knows. She sits back down quietly in the same place, her pleasure in listening has not diminished, it's just been enriched by a few thoughts that are no one's business.

Then the march comes to an end, but the performance doesn't yet. When Jacob reappears, worn out and happy and with a parched mouth, Lena firmly demands an encore, all good things come in threes and now more so than ever. That proves to him that she suspects nothing, how could it be otherwise, he thinks, if this march went well then there is nothing more to worry about.

"But this will be the very last one!" says Jacob.

He goes back to his original position, already thinking of the next program, he clicks. Lena is very lucky, he soon finds the station where fairy tales are told by a kind fairy-tale man who says: "To all the little children who are listening to us, the fairy-tale man will tell the story of the sick princess."

His voice sounds a bit like Sir Winston Churchill's, just as deep, only a bit softer, and, of course, without the foreign accent.

"Do you know it?"

"No. But how come there is a fairy-tale man on the radio?" "What do you mean, how come? There just is." 
"But you said radios are forbidden for children. And aren't fairy tales for children?"

"That's true. But I meant, it's forbidden in the ghetto. "Where there is no ghetto, children are allowed to listen. And there are radios everywhere. OK?"

"OK."

The fairy-tale man, a little annoyed at the interruption, but sufficiently fair to take some of the blame for it, takes off his jacket, lays it underneath because the pail is hard and has an edge and the fairy tale is one of the longer ones, if one is able to remember it all, that is. Good Lord, how long it's been, it had never occurred to him before, fairy tales weren't his father's responsibility, they were his mother's job, you lay in bed waiting and waiting for her to finish her housework and to come to you, and you almost always fell as leep waiting. But sometimes she did sit down beside you, slipped her warm hand underneath the cover and onto your chest and told stories. About the robber Yaromir with his three eyes who always had to sleep on the cold ground because there was no bed big enough for him; about the cat Rachka that didn't want to catch any mice, only birds, until he saw a bat; about the lake Shapun into which Dvoire, the witch, made all the children weep until it swelled up and overflowed and Dvoire drowned in it miserably; and one time about the sick princess.

"When is it ever going to start?" Lena asks.

"The Tale of the Sick Princess," begins the fairy-tale man.

About the good old king who ruled over a large land and had a first-class lovely palace and a daughter too, the old story about how he 
had a terrible scare. Because he loved her very much, his little princess, whenever she fell down and had tears in her eyes he had to cry too, that's how much he loved her. And he had a scare because one morning she didn't want to get out of bed and looked really ill. Then the most expensive doctor from far and wide was called, but the doctor examined her and listened to her heart, and then he said, being very puzzled: "I am very sorry, Mr. King, I can't find anything wrong. Your daughter must have a sickness that I have never encountered in my entire life." Then the good old king was even more worried, he went to the princess himself and asked her what for heaven's sake was wrong. And then she said to him, she wanted to have a cloud, if she got that she'd get better right away. "But a real one!" she added. That was quite a scare, because as anyone can imagine, it's not that simple to get a real cloud, even for a king. All day long he was unable to reign from sheer worry, and in the evening he had letters sent to all the smart men in his land, and in them it said that they were to drop everthing and come to his royal palace immediately. Right the next morning they were all gathered there, doctors and ministers, astrologers and scientists, and the king stood on his throne so that everyone in the hall could hear him and cried: "Si--lence!" Then everthing was very quiet and the king announced: "To that wise man among you who can get a cloud from the sky for my daughter I will give as much gold and silver as will fit into the biggest waggon in the whole world!" As soon as the smart men heard that they began clarifying, pondering, speculating and calculating. Because they all wanted all that gold and silver, how wouldn't they? An especially clever man even started to build a tower that was to reach up 
to the clouds. He thought to himself, when the tower is finished you'll climb up, you'll snatch a cloud and then you'll cash in on the reward. But before the tower was even half that height, it tipped over. And the others didn't have any luck either, not one of those wise men was able to get the cloud for the princess, who so badly wanted it. She got thinner and thinner and sicker and sicker, because she wouldn't eat a bite in all her sadness, not even matzos with butter.

One fine day the gardner boy, with whom the princess had played outside sometimes, while she was still a healthy girl, came into the palace to check whether flowers were missing in any of the vases. And he saw her lying in her bed under her silken quilt, pale as the snow. For the past few days he had already racked his brain wondering why she wasn't coming out into the garden any more, but he didn't know the reason for it. And so he asked her: "What's the matter with you, little princess? Why don't you come out into the sun any more?" And then she told him that she was sick and wouldn't get better until someone brought her a cloud. The gardner boy thought about it for a bit, then he shouted: "But that's quite simple, little princess!" "Really? It's quite simple?" the princess asked, surprised. "All the wise men in the country are racking their brains in vain and you claim that it's quite simple?" "Yes," the gardner boy answered, "all you have to tell me is what a cloud is made of." The princess would almost have laughed, if she hadn't been so weak, and she answered: "What silly questions you ask! Every child knows that clouds are made of cotton." "I see, and will you also tell me how big a cloud is?" "You don't even know that?" she asked, amazed. "A cloud is as big as my pillow. You can see that 
for yourself if you just push aside the curtain and look at the sky." Then the gardner boy went to the window, looked at the sky and exclaimed: "That's right! Just as big as your pillow!" Then he went on his way and he soon brought the princess a piece of cotton, and it was as big as her pillow.

I won't bother with the rest, everyone can easily imagine it, how the eyes of the princess grew bright again and her lips red and healthy, how the good old king rejoiced, how the gardner boy didn't want the promised reward but the hand of the princess instead, and they lived happily, that is Jacob's story.

It is probably the same evening, or maybe the one before or after: tender, beautiful Rosa is lying with Mischa, listening to the battle at the Rudna. Mischa is telling it softly but he isn't whispering, there is a big difference between speaking softly and whispering, one might rightly ask: Why isn't he whispering? And one might ask why the dresser isn't standing in the middle of the room any more, but rather in its usual position against the wall, and why the curtain is covering the window again instead of dividing the room into two halves. What happened to the folding screen, one might wonder, and above all why is Rosa lying there naked all of a sudden, even though the light is still on, why isn't she embarrassed any more? Then one will kindly take a look at the second bed and find it empty, and all questions will lead to one: Where is the deaf and dumb Isaak Fajngold with his sharp ears?

I don't know that any more than Mischa, and least of all Rosa, a week ago he went to work early in the morning, as he did every day, and 
he hasn't been seen since. The first evening no one was very worried yet, Mischa thought perhaps he went to visit a friend, chatted for too long and then noticed that it was already past eight o'clock and too late to go home, so he simply lay down on the floor and spent the night there. "What do you mean: 'chatted too long'?" Rosa asked suspiciously. "Isn't he deaf and dumb" "Well, do you think deaf and dumb people can't talk to each other?" Mischa answered quickly. "Do you think they are condemned to keep to themselves everything that goes through their minds? They can communicate just like you and I, only in sign language."

But on the second evening Fajngold didn't come home either and not on the third, and so on the fourth day Mischa went to the only acquaintance of Fajngold's he knew of, to Hersh Prashker. The one who works with Fajngold in the sanitation squad, clearing the streets of rubbish and starving people, but Prashker had no idea either. He said:

"Tomorrow I was going to come see him in his apartment, to ask why he wasn't showing up for work. They'll come and get him yet, he's already on their list." "When was the last time he was there?" "Tuesday." "And Wednesday morning he left home as usual."

He never did arrive, he never did come home, perhaps he escaped or died or had an accident or was arrested right on the street. Death or an accident seem unlikely because he was never found any place, we asked around. A planned escape seems unlikely too, since all his things are still in the dresser, not even the photograph of his grandson is missing, he would never have parted with that, he cherished it like a treasure. That only leaves the arrest on the street, God only knows 
what for, because Fajngold was always a capable and law-abiding man; but we all know the expression, where there is a will there is a way. And from all that it is quite obvious why Mischa is telling softly about the battle at the Rudna rather than whispering.

It's already the second evening in a row that Rosa has been lying next to him, and that has never happened before. Old man Frankfurter, a man of the theater and not really a friend of very strict mores, cautioned them: "All right you kids, you are in love with each other, I can understand that. But there is no need to go overboard right away." For that reason and also because of Rosa's shyness, the number of nights spent together so far has been modest, Mischa had to talk her into each one as if it was her first, with very few exceptions. And now the second one in a row already, Rosa imagines marriage to be somewhat like this, but, quite frankly, she doesn't feel at ease this way. It isn't because of Mischa's being any different from before, more aggressive or inconsiderate, his worth has not diminished one little bit, she regards him with no less love than she did on the first day. Or let's say on the fifth. It's really because of Isaak Fajngold, mysterious as that may sound; one had gotten used to him in a strange sort of way. But how can one get used to someone who is always in the way, no matter how deaf and dumb he may be? In this kind of situation, where being alone is so crucial, how could one? One can and one can't, we'll try to explain: first of all, it's in this room that Rosa began to love, in Fajngold's presence, he was there from the very first second, the secrecy with regard to him was a definite ingredient in all her caresses. Then secondly, Fajngold's bed isn't just empty now, no, Fajngold is not lying 
in it any more, that makes quite a difference. Every glance behind the folding screen that has now become superflous and has therefore been folded up, is a reminder of his obscure fate, uncertain to be sure, but the longer one racks one's brain, it's uncertain only with respect to the way he died. And thirdly and lastly, when Mischa told her that Fajngold had disappeared her eyes looked terrified, as one might expect, but after a while her eyes no longer looked so terrified, she caught herself thinking: at last. That wasn't anything against Fajngold, she wished the best to him, it only had to do with her and Mischa and was supposed to mean, alone at last, uninterrupted as last, at last a private corner for the two of us. She caught herself thinking it, and she felt bad, she found such thoughts shameful and yet she found herself thinking again and again: at last. Then she thought too, it's a good thing Mischa doesn't know what selfish ideas go around in my head. And she also thought, whatever happened to Fajngold happened in this one way, thoughts one keeps to oneself can have no bearing on life.

But they did have a bearing, it wasn't quite that simple, for several days she made up excuses for Mischa as to why she couldn't come to his room with him, and he left, disappointed. Until yesterday, until she could or would find no more excuses, he asked her: "And why aren't you coming today?" She answered: "But I am coming," and that's when he said it: "At 1ast!"

They went into the room, Mischa had already changed things around ahead of time, for Fajngold's absence could be regarded as final. The dresser, as mentioned, now stood against the wall, the curtain hung on the window, Rosa stopped in the middle of the room and had to get used 
to it. Because she had never seen it like that yet. Fajngold's neatly made up bed attracted her attention, of course; she could feel right away that it would cause problems yet. She asked: "What is that box?" "His stuff. In case someone comes to get it," Mischa answered. And immediately the right mood was set.

At some point they lay down, but were silent for a long time and motionless and joyless, how different everything was this evening, the light was still on. Mischa way lying on his side, she on her back, because the bed is too smalli for two to lie on their backs. With a glance at Fajngold's neatly made up bed he asked: "What do you think, couldn't we. .."

"No, please!" she interrupted him anxiously.

"All right."

He turned off the light, put his arm under her head, that's how it usually starts too, and wanted to kiss her, but she turned away. Until he asked her: "What's wrong with you?"

"Nothing."

He thought about it for a while, what might "nothing" mean, then he said: "But you hardly knew him. And even if you did, what can we do about it?"

He wanted to kiss her again, she let him now, but only let him. Soon he realized that he couldn't get anywhere with her, so he closed his eyes, tomorrow is another day, and went to sleep. That was the only thing that was just as usual, he always fell asleep first.

In the middle of the night she woke him up, he wasn't mad, he hoped that she had changed her mind at last, and that is well worth waking up for. 
"I have to tell you something, Mischa," she whispered. "Yes?"

The fact that she was silent was misinterpreted completely, he pulled her over to himself and wanted to touch her face with his lips, and then he noticed that it was wet and salty from the eyes down. That was quite a shock to him, because he was used to the fact that she rarely laughed and never cried, even when her only girl friend had to get on the train six months ago she couldn't cry, though for days one didn't get a word out of her. And now suddenly this wet face, that's quite a shock indeed, but she didn't sob or whimper, it must have happened very quietly, he wouldn't even have woken up if she hadn't wakened him. And anyway, it was a good as over, judging by her voice.

"I have a request that will seem strange to you."

"Tel1 me.

"I would like the room to be as it was before."

"What do you mean: as before?"

"The dresser in the middle again. And the curtain."

"But what for? Fajngold isn't there any more."

"I would like it that way."

It really did seem strange to him, first strange, then childish, then silly, then simply ridiculous. Then he remembered having once heard or read something about the mysterious whims of women and that it is advisable to nip them in the bud. The whole change she was requesting wouldn't have cost him more than ten minutes, but he said: "Only if you can give me a sensible reason"

"I would like it that way." 
That was not a sensible reason, not by a long shot, and so he persistently refused. He said that it was to her credit if Fajngold's disappearance affected her so much, even though she did not know him, only his breathing and snoring. But in the ghetto many people are lost every day whom one knows just as little, and if one made such a fuss about each one it would be unbearable. And she accused him if being an indifferent, boorish clod, their first fight was on its way, and if it hadn't been for the eight o'clock curfew she would have gotten up, dressed herself and good bye. But instead she just turned her back to him so that he would notice how much she despised him.

The next day, that is today, he went to pick her up right at the factory, because a reconciliation at her house would have been much harder in the presence of her parents. It was difficult enough already, not for lack of good will but because one had so little practice at ending quarrels. In the end both of them admitted that they hadn't behaved well, a kiss in a doorway and breathing was much easier again. They dropped by her house to tell where she was spending the night. Frankfurter didn't look too enthusiastic, he couldn't know that last night had been practically wasted, Mischa heard Mrs. Frankfurter say to her husband: "Let her."

Then to his room, they both tried their hardest to be friendly to each other, showing one another their best sides after the quarrel, but one could feel that a little more time had to go by for everything to be just as before.

Mischa told her about the battle at the Rudna, or rather, since we're all caught up again, Mischa softly tells her about the battle at 
the Rudna, finishes it at last, heard it just today from Jacob, the latest from the air waves, so to speak. Rosa melts with joy, everyone knows where the Rudna flows and how much progress since Bezanika this battle means, she would't mind at all starting to make new plans again. But Mischa doesn't feel like making plans, not at the moment, they won't run away like this evening might (the second one in a row); he turns off the light. In order to devote himself to Rosa, let's not talk of victories any more, last night was practically wasted. The Rudna and Fajngold and angry words are forgotten, it's easier to get close to each other in old familiar ways, if one's own will has any say in this. But one's own will doesn't rule alone, one catches oneself making comparisons, so that's how it is now, really no different from before, one finds oneself lying a little bit beside oneself and watching things. And perhaps one even hears that no strange breathing from the other half of the room is there to disturb anything. Let's just be frank about it: making up for a missed night turns out to be only moderately successful, even if they would never admit it, even if they are acting happy as young lovers.

With slight regret we will leave them, in the hope that more carefree times will return, surely that hope is allowed. Let's just hear Mischa ask with a smile and still riding on the wave of reconciliation, what he probably shouldn't have asked at all: "Do you still want me to divide the room with the dresser and curtain?" He says that, smiling no less, because for him there is no doubt that Rosa sees things differently now, that she will start talking about silly moods and say she doesn't know either what got into her yesterday, and that the whole unfortunate incident would best be forgotten. 
And let's just listen to Rosa say: "Yes, please."

Jacob has to hear with his very own ears how distortedly his information is passed on.

Jacob wants to go to Lena in the attic, it's not time for bed yet, but one has to do more with her than just make sure she washes herself properly, brushes her teeth and goes to bed at the right time. At the freight yard they let us go two hours early, there simply wasn't anything more to be loaded, the guards didn't feel like supervising idlers, they told us to scram. A few especially bold speculators suspect that there is much more behind this order than just laziness, perhaps these gentlemen of the guard want to befriend us, they reason, they could just as well have let us wait around for two hours. We were made to line up, but they sent us home, maybe new times knock at one's door in unconspicuous ways such as this.

In any case, these two hours will be well spent with Lena, Jacob thinks at first; when he puts his hand on the doorknob he hears that she is not alone. He hears Rafael's voice asking: "What's it about, anyway?"

"About a princess," says Lena.

"Is she kidnapped?"

"Why do you think that?"

"Of course she is kidnapped. I know that stuff. She is kidnapped by a robber. He wants to have a pile of money for her ransom but the prince kills him and sets her free. And afterwrds they get married." 
"What nonsense!" Lena says, annoyed. "That's a completely different story. Do you think there is only one fairy tale about a princess?"

"Then why don't you just tell it?"

"Aren't we going to wait for Siegfried?"

"He's not coming."

Jacob hears them waiting, the attic window flies open, Rafael yells: "Siegfried!"

Then he says that Siegfried is nowhere to be seen, and soon after Lena insists with a shriek that Rafael cut out that nonsense. It's not clear what nonsense, but it sounds as though he's not stopping it right away, then he asks: "From whom did you hear this story?"

"From Uncle Jacob."

That's quite revealing if one is secretly standing behind the door. Jacob never once told her a story about a princess, surely he would remember that, it was the fairy-tale man, and here she is making one man out of two different people without even a hint of unsteadiness in her voice. That's pretty revealing, quite possibly it was Jacob who played the march music too and who asked questions and gave answers. Or else Lena made a mistake in her haste, or, and that would be the best, she is resorting to a white lie, in order not to tell about the radio. That's still up in the air, one will have to talk about that yet.

"He's not coming. Go ahead and start." says Rafael.

And that's how it starts, Lena clears her throat, Jacob perks up his ears, he has never heard how his information is passed on.

"Once upon a time there was a king, he was a good old king and he had a daughter, and she was the princess," Lena begins. 
"What was the king's name?"

Lena seems to be wondering if names were even mentioned, too long for Rafael, he says: "Don't you even know what his name was?"

"His name was Benjamin," Lena remembers. "And the princess was called Magdalena."

"What was his name? Benjamin? Do you know who is called Benjamin. My uncle in Tarnopol, he is called Benjamin. But not a king!"

"You can believe it or not, but anyway the king in this story was called Benjamin."

"Well, all right," says Rafael magnanimously, let's not worry about the name. Jacob is almost sure that he has his arms folded across his chest in a patronizing sort of way.

Lena keeps going, but more hurriedly than at the start, as though disconcerted, as if she's expecting further objections: "One day the princess got sick. The doctor couldn't find anything wrong, because he didn't know her disease, but she wouldn't eat anymore bread and she wouldn't drink anything either. So the king himself went to her, because he loved her very much, I forgot to say that. And he asked her what was wrong. She said to him that she wouldn't get better until someone brought her a piece of cotton just the size of her pillow. And so the old king. . ."

But she doesn't get any further, Rafael has had enough of it, he tried very hard to listen patiently, but too much is too much, his naivete has its limits.

"What kind of sickness did you say your Magdalena had?" 
"You heard it, didn't you?"

"And I am telling you, there isn't any such disease. Not in the whole world!"

"You don't know that!"

"If at least she had the measles or the whooping cough or typhoid fever," says Rafael indignantly. "Do you know what the princess really had? A fart in her head!"

He laughs, much louder than Jacob, but Lena can't find anything funny in his explanation. She asks: "Do you want to hear the rest of the story or not?"

"I don't want to," says Rafael, still amused, the best jokes are one's own. "Because she had a fart in her head, you see? Because the whole story is total nonsense. First of all that stuff about the king, you won't find a king named Benjamin in the whole wide world. Secondly, princesses never eat bread, but only cake. And the biggest nonsense of all is that disease. Have you ever seriously heard about anyone getting sick because he didn't have any cotton?"

Lena seems impressed by Rafael's line of reasoning, at any rate she is silent, hopefully without tears, Jacob thinks. And he is still convinced, she is a smart girl, anyone can make a mistake, all the excitement in the basement may have caused the misunderstanding, or maybe at Lena's age such a sequence of thoughts is too much. Jacob's hand is back on the doorknob, one should interfere, comfort, and explain, it'll come to blows between them yet, may God forbid. One could just go in very innocently, hello Lena, hello Rafael, nice of you to come visit her, how's your mother? Then the conversation will turn 
to their point of disagreement all by itself, it will be related by each party, quiet children, let's take turns now. Then one will surely find some soothing words, which will make matters appear in a new light, no reason at all, children, to be so angry at each other, the truth of the matter is such and such, and in the end there will be good will and understanding. He is about to plunge into the battle when he hears Rafael's conciliatory voice: "Next time your uncle tells you a fairy tale, tell him to come up with something better than that kind of nonsense. That princess, you know, had a great big fart in her head."

The chance of interfering does not present itself, the door opens, Jacob's good old familiar luck with doors, it opens towards the outside, providing a hiding place for him. Rafael takes off for a more worthwhile amusement, no doubt he wants to look for Siegfried and report to him. One can hear him running down the stairs whistling, he is whistling "Oranges and Lemons," he is even whistling while Lena is shouting after him the last little bit necessary for the completion of the story: "She did so have that disease! And the gardner boy got her the cotton! And she got all better and they got married!"

All has been told, though to closed ears, downstairs a song dies away and the front door clicks shut, and upstairs a disappointed long tongue sticks out as the attic door closes with a bang. Jacob, as before, in front of the door, doubts are springing up, are these two free hours still well spent with Lena? He tells me it really was kind of funny, those two kids, but suddenly he didn't feel like going in any more, suddenly he felt tired out. He wanted to keep the two hours for himself after all. And he asks me if he is boring me with all those details and would I tell him. 


\section{I tell him, "No."}

Jacob goes for a walk for his two hours, there are other ways to rest besides in small rooms and with children that have grown dear to one's heart, he still has an inclination to go for strolls, despite spotlights and police stations. Strolling in a little town from which you never went further away than one week, the sun is shining brightly on your way, as bright as those memories, for the sake of which you left your house and toward which every other street builds a bridge for you to walk on, it's all familiar already. Twice around a corner and there you are in front of the house in which many a time it was to be determined how good your next winter was going to be. None other than Aaron Ehrlicher, the potato dealer, lived there. Much depended on the prices he set, the pancake price and therefore one's intake. He never made any deals with you, this much and not one groschen less, if that's too expensive for you, Mr. Heym, you are welcome to shop around elsewhere for cheaper potatoes. And when you've found a place, kindly let me know, I'd like to buy there too. Not once did he make any kind of a deal with you, Jacob once said to him: Mr. Ehrlicher, you're not a potato dealier, you're a potato salesman." Just for a joke, of course, but Ehrlicher did not split his sides laughing. One was never certain whether he was a poor wretch, small tradesman like oneself, or a business man of the larger category. His wife wore a beautiful brown fur coat and his kids were fat and round and conceited; on the other hand, his office smelled of mildew, small and shabby, only a table and chair and bare walls, he used to point it out with a sigh and ask: "How am I supposed to lower prices under these circumstances?" 
Strangers live there now, you turn over the page with Aaron Ehrlicher and walk on, two free hours are a long time, you go to Libauer Lane, right up to number 38 . There isn't a house you go to as of ten as to this one when you are out walking, and you stand there longer than in front of any other, there are good reasons for that. Even the fact that you enter the dark courtyard has its reasons, suspicious eyes peer at you through windows, what's a stranger doing in their courtyard, but you're not such a stranger around here, really.

On the fourth floor, behind the last door on the left at the end of the hallway, that's where you, to be pompous about it, gambled away a lifetime's happiness, or where you won it, you couldn't make up your mind when everything depended on it, and to this day you don't know how good or bad that was. Josefa Litwin asked you to your face where exactly she stood with you, and you couldn't think of anything more intelligent to do than to stare at your toes and to stammer that you needed some more time to think it over.

She was a prize of a woman if you were judging with your eyes, you saw her on the train for the first time and you immediately thought: Boy, oh boy! She was wearing a green velvet dress with a white lace collar and a hat no smaller than an open umbrella. And was at the very most in her mid-thirties, just right for you at forty at that time, just right as $f a r$ as age was concerned. But in that train compartment it did not occur to you in your wildest dreams that right there across from you sat what was to be your biggest problem for the next few years. You only gawked at her like a young idiot, you tell me, maybe she didn't even notice. A coincidence or no coincidence, but both of you got of $f$ 
together, no porter nearby, she asked you if you couldn't perhaps carry her heavy suitcase, she lived only a few streets away, at Libauer Lane, number 38. But she didn't ask you as a man of lower class, even though you wouldn't have refused then either, she was helpless and friendly and asked you for a favor in her capacity as weak woman. In your capacity as gentleman. Full of joy you said: "What a question!" Grabbed her suitcase, as if you were afraid some porter might show up after all, and walked behind her to number 38, to her front door. There you put down the suitcase, for a few seconds you smiled at each other embarrassedly, then she thanked you nicely and said "Good bye." And you stood there thinking: too bad.

A few weeks later, and that must have been a coincidence, she came into your cafe one afternoon, accompanied by a man. You recognized her immediately, were annoyed about the man without having any right to be, but then you were happy because she recognized you too. Neither one of you said a word, the two of them drank lemonade and ate raspberry icecream, you watched them and couldn't figure out what their relationship was, and what for?

But when she came back the very next day, this time alone, you knew it was no coincidence. For the first time you were glad that your cafe was empty, besides her there wasn't one customer in the room, and the next day again. You sat down next to her, chatted and got acquainted, she had been the widow of a clockmaker for the past four years. The icecream she had ordered you didn't let her pay for, she was to consider herself your guest, today and as often as she liked. The man from yesterday was called a casual acquaintance, no reason not 
to get together more often, no reason of any kind. Well, see you tomorrow in the cafe, and again in the cafe, then in another restaurant, in a neutral place so to speak, a little dance now and then. And soon at your place, by now you had been informed about her modest, yet by no means meager financial status, and about the fact that she had no children, and finally at Number 38 as well. A little cup of tea and homemade cakes, delicate perfume sweetened the air, fondness at first sight, really, was the topic, and another little cup, and there were more little cakes out there.

That was an evening, the like of which has never been described by any poet, my God, and a night, my God,. . .oh, well. What can one say, our story is not about Jacob and Josefa, soon this page too will have to be turned. Only this much more, four whole years came out of that, four years of living together as man and wife, even if they never did move in together for good, even if one topic was always avoided: Rabbi or civil wedding. Most of all by Jacob, I guess. One had a chance to explore each other thououghly, Josefa's glitter wasn't all gold, there were some other less precious metals mixed in as well. Sometimes Jacob found her tyrannical, sometimes too talkative, sometimes not enough of a homemaker and she too found fault with him here and there, without it leading to a breakup right away. Quite on the contrary, they got on quite well with each other despite everything, and Jacob was thinking already that it would continue like this for some time. But when she suddenly suggested to him--did I say suddenly?--that they should perhaps move into an apartment together and that she could help at the cafe, at that point he feared that he was about to become his own employee and said: "We'll talk about that some other time." 
All right then, some other time, Josefa was in no hurry, or so it seemed. Until, as I said, that evening rolled around, the one at 38 Libauer, in which Jacob gambled away or won a lifetime's happiness, who can possibly know that? He arrived as usual, took off his shoes, laid his feet on the sofa just as usual, Josefa stood at the window wih her back turned to him.

"What's the matter with you today?" Jacob asked her. "Isn't there any tea?"

Josefa didn't turn around right away, but pretty soon. She had a forbidding look and she didn't sit down beside him on the sofa, but on the armchair opposite him.

"Jacob Heym, I must have a talk with you."

"Go ahead," he said, prepared for all kinds of things, but not for what was coming.

"Do you know Avrom Minsch?"

"Should I know him?"

"Avrom Minsch is the man with whom I came to your cafe the very first time, in case you remember."

"I remember exactly. You said at that time that he was a casual acquaintance."

"This morning Avrom Minsch asked me if I wanted to be his wife."

"And what did you tell him?"

"Jacob, this is serious! You are finally going to have to make up your mind!"

"Me?"

"Stop your jokes, Jacob. I am thirty-eight years old now. I 
can't keep living like this forever. He wants to join his brother in America, he asked if I would like to come along as his wife."

What was Jacob to answer to that, the pistol at his chest did not much please him, but even less the fact that Arrom Minsch had to this hour been kept a secret from him. One doesn't make a marriage proposal to a casual acquaintance, one has to know a woman at least a little bit in order to do so, and for four years one imagined one knew everything about each other to the last detail. The fact that Josefa was offering him the first bid, so to speak, did nothing to ease Jacob's disappointment, not by a long shot. He put his shoes back on without saying a word, carefully avoided meeting her eyes until he reached the door, and standing in the doorway he said, embarrassed: "I'll have to think that over first."

One thinks it over and over, to this very day one has been unable to arrive at a decision, even two generous hours aren't long enough, a sympathetic person opens a window and calls out softly across the yard: "Hey, Mister!"

Jacob is startled and sees the moon above the roof, Jacob asks: "What is it?"

"You don't live in this house, do you?" "No."

"It's long past seven already."

"Thank you."

Jacob pulls himself together, no more stopping on the way home, all the other houses inhabited by possible memories have to remain unnoticed, it's long past seven already. 
Lena is already in bed, one has to explain to her why one has returned so unusually late from work, because today there was especially much to be loaded. And because of that she doesn't talk about personal worries with fairy tales or with overly suspicious neighborhood boys, and Jacob can't very well ask her about it either. She knows how exhausting the days at the freight yard are, and then his additional work, he mustn't stay long, just quickly give her her kiss and go to his room, their love is entirely mutual.

Jacob leaves her with a conscience that could be clearer, on the stairs he plans to make it up to Lena, tomorrow or real soon. Meanwhile at his table he is, all in all, not dissatisfied with the past day, sitting there in front of his supper of bread and malt coffee: at the freight yard the Jews were reasonable and reserved, the battle at the Rudna was still having its effect, then two hours of daydreaming for a special present: an enjoyable fairy tale behind the attic door, a less enjoyable Aaron Ehrlicher, but then Josefa. And now Josefa still, between meagre bites, between gulps, one simply can't get away from that woman, what would have become of us two charmers if at that time in number $38 \mathrm{I}$ had. . .? Who knows, and yet the same question that has been asked a thousand times can be answered so easily: it would have been a life halfway between paradise and hell, that is, an ordinary one. How could it have been different from those four familiar years? Which were filled with variety, quarrels and misunderstandings, with moods, fun, and with a little bit of comfort. And with secrecy too, as was discovered on the very last day. One simply can't get away from that woman, not until there is a knock at the door. 
There is a knock, Jacob feels like calling out right away: "Come in, Kowalski!" That is, he doesn't exactly feel like it, he only suspects, but then he doesn't suspect any longer, because it was past seven more than one hour ago, and it must be way past eight by now, and even Kowalski isn't that crazy, Jacob calls: "Come in!"

Professor Kirschbaum honors Jacob with a supper visit, is it inconvenient, no, of course not, won't he sit down, what do we owe this rare pleasure to?

Kirschbaum sits down, delays the beginning of the conversation with frequent glances outside, thus assuring himself of worried attention, Jacob doesn't know what for.

"Can't you imagine why I am paying you a visit today, Mr. Heym?" The first thought: "Is it because of Lena? Has she gotten worse again?"

"I am not here because of Lena. I am here, to come right to the point, because I would like to speak to you about your radio."

One can't help being disappointed, being crushed, for a few hours that monster of a radio had been forgotten, pretty soon the battle at the Rudna will have to be dragged out again. Gone are the times when one was regarded as a human being by one's fellow citizens, now one is simply a radio owner, those two are incompatible with one another, that has long been proven as it is at this moment, the right to any normal conversation as in former times has been thrown away. The weather, or those pains in the lower back, for which Kirschbaum would be an ideal partner, any gossip about mutual acquaintances, juicy little tidbits, are not discussed in your presence, you and your treasure are much too 
important for that. "You want to hear news too," says Jacob, or rather registers it mentally, now Kirschbaum on one's neck too, oh well, one more or less.

"I don't want to hear any news," Kirschbaum says, however. "I have come to reproach you. I should have done it long ago."

"Reproach?"

"I don't know, dear Mr. Heym, what motives you may have been guided by when you were spreading all that information. But I have a hard time imagining that you have carefully considered to what danger you are exposing all of us."

Not news but reproaches, if one only had some good ideas, there is no way around it, Kirschbaum is a very special kind of person. Do you, professor, have to come spitting into my leisure time, my hard-earned time, do you have to lecture me about responsibility, about issues that were already an old hat to me when my radio was still completely unknown to you, you have to come to do this to me? Instead of patting me on the back and saying bravo Mr. Heym, keep it up, there is no medicine people need as much as they need hope, or if not that, instead of at least staying away, since one has learned long ago to be able to get along without pats on the back; but you come knocking at my door, may the devil take you away, you come meddling in my business wanting to teach me how to survive. And to top it off, one has to wear an attentive expression, because your misgivings are nonetheless thoroughly honorable, because one might need you again for Lena, and one has to come up with good reasons for one's actions, even though one can't think of any, which is no business of yours. And all this in order that after long 
explanations your learned mouth will be in a position to say: "Oh, I see, yes, yes, now I understand."

"I don't have to tell you where we are living, dear Mr. Heym," says Kirschbaum.

"You certainly don't," says Jacob.

"And yet it seems to me to be of some urgency. What if, for example, the Gestapo got wind of this information? Have you thought of that?"

"Yes."

"I find that impossible to believe. Because in that case you would have behaved differently."

"Is that so?" says Jacob. "Would I?"

Jacob gets up for a stroll, how many strolls have there been today, past table, bed, closet and Kirschbaum, his anger, finding no words, goes to his legs. But not all of his anger, the room is too small for that, a tiny little bit that can't easily be ignored is left for his voice, quite annoying to Kirschbaum at first. Then Jacob says: "Have you ever once seen their eyes when they ask me for news? No? And do you know how badly they are in need of good news? Do you know that?"

"I can well imagine. And I have no doubt that you have the best of intentions. Nevertheless I must. . ."

"Leave me alone with your 'nevertheless'! Isn't it enough for you that we have practically nothing to stuff into our mouths, that every fifth one of us freezes to death in the winter, that each day half a block is carted away? All that isn't enough? And if I try to take 
advantage of the very last chance that might prevent them from simply lying down and croaking, with words, do you understand, with words I'm trying that! Because that's all I've got! And here you come along and tell me it's forbiden."

Oddly enough, at this very moment Jacob finds himself thinking of a cigarette, he tells me, of the Juno without filtertip; what Kirschbaum is thinking is uncertain. At any rate, he reaches into the pocket of $h$ is threadbare double-breasted jacket, one won't believe it, at this very moment, and takes out a box. And matches, and asks Jacob whose yelling has just barely died away, exceedingly politely: "Would you like one?"

A question, that's how it goes amongst civilized people, a sensitive example perhaps, a good one, and perhaps an expression of slight doubts popping up, or neither of the two. They are silent and they smoke and they smoothen out their wrinkled foreheads.

The greedily inhaled smoke doesn't just spread well-being, it brings peace as well, let me tell you, Jacob experiences a change of heart while smoking, or something of the sort. Because a noble donor is timidly sitting in front of him, Kirschbaum is helplessly fiddling with his cigarette, turning it in his narrow fingers, hardly daring a quick glance now and then, let alone to open his mouth for anything more than the next puff. Because whatever he does will be followed by outbursts of temper, leave me alone with your "nevertheless". Or: isn't that enough for you? Came by in order to have a talk with his neighbor, after all a radio like that isn't a piece of private property like a chair or a shirt, did not come by to accuse, but rather to discuss 
important matters in calm dialogue, and then this: "and here you come along and tell me it's forbidden." Kirschbaum hasn't left, that's a sign of good will or of unusually strong fear, he stayed, reached into his pocket like a magician and fulfilled secret wishes, how could one begrudge him a few neighborly words.

"Of course I know that it won't make the Russians arrive any sooner," says Jacob halfway through his cigarette. "Even if I tell it a thousand times, their route will be the same. But I would like to draw your attention to another small detail. Since the news reports have been circulating in the ghetto I haven't heard of one case of anyone killing himself. Have you?"

Kirschbaum looks amazed and says: "You're right."

"And there used to be many, no one knows that as well as you. I can remember that you were often called in, and in most cases it was too late."

"Why didn't I notice that?"

One of the following days brings something unheard-of, a car drives through our little town, the only passenger car in this long story. Unheard-of for sure, but nothing to pin one's hopes on, not even for the most imaginative amongst our bolder speculators. One feels inclined to say, quite on the contrary. It is travelling in a straight line, without detours, the exact route must have been studied on the map beforehand, it's a black one, the streets become deserted as it approaches. In the back seat are two men in plain clothes, behind the steering wheel a neatly pressed uniform, only the two in the back play a 
role in this. That is, they too aren't super important, when you come right down to it, the whole car isn't important, despite it's SS banner, or where it's coming from, or where it's going, or whom it's taking with it. Or let's say a little bit important, or: not entirely unimportant, as far as the consequences are concerned.

The two men are called Preuss and Meyer, I know what they are talking about, I don't know what they are thinking, although that doesn't present an insoluble puzzle, I am familiar with their military rank, if necessary even with their brief resumes, and hence with their names as well. Unfortunately I will have to meddle in the story in a rather heavy-handed and direct manner later on when explanations are in order, because a gap is to be avoided as much as possible. My explanation will fill it somehow, but later on, first the gap will have to be visible to its full extent.

The car stops in front of Siegfried and Rafael who are hanging around the street as usual, on the curb, and who, being the only heroes in sight, are not hiding. All the other Jews, being neither blind nor lame, are standing behind their windows or in protective hallways, trembling because of two crazy kids and the yet uncertain disaster which the German car must be about to cause. But many a person will think the disaster isn't all that uncertain, after all the car isn't stopping in front of any old house, it's stopping in front of Jacob Heym's house.

Preuss and Meyer get out on a special mission, Preuss is a rather tall man with brown hair, slim, good-looking, perhaps a little soft, Meyer, as he was described to me, about a head shorter, gruff, at first 
sight bitterly resolute. Probably a carefully thought-out combination, each has what the other lacks and vice-versa, a good match. They go into the house.

"Do you know which apartment?"

"One flight up," says Meyer. "The names are supposed to be on the doors."

One flight up, Jacob lives two up; anyway, one up, right to Kirschbaum's door. A well-mannered knock and patient waiting, until a woman's voice, sounding as though company is arriving at a very inconvenient moment, asks: "Who is it?"

"Open up, please," says Preuss.

Although there is no very plausible reason for opening, a key is poked into the lock, turned around, the door opens just a crack at first, then without reservation, there is really no need for Meyer to place his foot between door and threshold. And there is Elisa Kirschbaum, old and stern, with well-disguised fear. Her much mended apron can't fool us, it isn't just anyone looking at us, the way she holds her head already, this is a lady looking us over, Preuss and Meyer. Her fear is well disguised, her scorn is not, an indifferent glance at the faces of two bothersome visitors, then a glance at Meyer's foot, which is protruding so terribly pointlessly from the threshold, Meyer is fidgeting.

"You wish to. . .?"

"Hello, says Preuss politely, perhaps he can't help it when confronted with such glances. "We would like to see Professor Kirschbaum." 
"He is not at home."

"Then we' 11 wait," says Preuss, determined. He walks past her through the door, at last Meyer too can free his steadfast foot from its position, he follows him. They look around the room, what are they all talking about, they aren't so badly off here, buffet with knicknacks, sofa and two armchairs, a little threadbare of course, but still, bookcase jampacked with books like at the movies, on the ceiling a three-armed lamp, almost a chandelier, they live like kings here, maybe only this Kirschbaum, he is supposed to have been somebody, special ration or something, they've sure got brains these kikes, they always manage somehow and immediately feel at home anyplace.

Meyer plops down on the sofa, Preuss doesn't yet, because Elisa Kirschbaum keeps standing at the door and doesn't stop looking as though she is waiting for an explanatin.

"Are you Professor Kirschbaum's wife?

"I am his sister."

"You'll allow me."

Preuss sits down too, in an armchair, and crosses his legs, lots of time, Elisa Kirschbaum stands. There is nothing for it, she has to ask: "What is it about, please?"

"That's none of your damned business," says Meyer. He can't remain silent any longer, what's happening here seems unreal to him anyway, a farce, just a farce, but not at his expense. To an outrageous question he wants to give more than just an answer, to bend the world back into shape a bit is what he wants to do, otherwise where will it all end? 
Well, yes, Elisa Kirschbaum can't simply call the maid and ask her to get this boor his hat, her arsenal of weapons is terribly empty, but at least she can punish Meyer with scorn, turn to Preuss and coldly demand: "Would you kindly tell this gentleman that he is in a stranger's apartment and that I am not used to such behavior?"

Meyer begins to bristle, he is about to jump up, get mad and yell, but Preuss looks at him in an official manner, special mission, then he says: "You are quite right. Sorry."

"You were going to tell me why you came."

"I think I would rather explain that to the Professor in person. Do you know when he will come home?"

"No. At eight at the latest."

She sits down in the unoccupied armchair, very straight, she puts her hands in her lap, well then we'll wait. I can just go ahead and say it, Kirschbaum arrives after about half an hour, the time goes by with trivia. For example, Meyer lights up a cigar, throws the match on the floor, Elisa Kirschbaum picks it up, brings him an ashtray and opens the window. Meyer feels unsure.

Or, Preuss gets up after a few measures worth of druming on the table, he is interested in the bookcase. He opens the glass door, bends his head towards his shoulder, reads the book backs, takes out a book, leafs through it, another one, leafs through that, all this for quite a while, puts all of them back in the right places.

"Those are exclusively books on medical subjects," says Elisa Kirschbaum.

"I see." 
"We got written permission for them, "she says. And, as Preuss still continues looking at some others: "Do you perhaps wish to see it?"

"No, thanks."

He finds one that particularly appeals to him, he sits down with it and is occupied. Forensic medicine.

Or, Meyer suddenly jumps up, dashes to a door, tears it open, looks into an empty kitchen, calms down again, sits down.

"Could have been," he explains to Preuss who continues reading. Or, Meyer gets up again, this time without haste, goes to the window, looks down. He sees two women dragging two children away from the car into the house across the street, sees a face behind almost every window pane in that house, the uniform is standing by the car, bored.

"Could be a while yet," Meyer shouts down. Then he sits back down, as I said, half an hour.

Or, Elisa Kirschbaum goes into the kitchen, one can hear her bustling, she comes back with a tray. Two dinner plates, two cups, knives, forks, teaspoons, two cloth napkins. She sets the table, Preuss hardly looks up from his book, but for Meyer that is going too far.

Preuss hardly looks up from his book, he says: "Let her."

After about half an hour the Professor arrives. One can hear his attempt at getting the key into the doorlock, there is another one on the inside, Meyer puts his cigar in the ashtray. Preuss lays the book on the table, between the plates. Elisa Kirschbaum opens up. 
The Professor remains standing at the door, terrified, there is no great attempt at hiding it, even though one isn't standing there entirely unprepared, there's the car parked in front of the house. Of course one would have hoped for its connection with Heym, or rather, not hoped but assumed, the only thing one hoped for was no connection with oneself, in vain. Preuss gets up.

"We have guests," says Elisa Kirschbaum. She takes the forensic medicine off the table, puts it back into the bookcase, closes the glass door. With a cloth that she takes out of her apron pocket she wipes off any possible fingerprints.

"Professor Kirschbaum?" Preuss finally asks.

"Yes?"

"My name is Preuss." And then lookes over at Meyer. "Meyer," growls Meyer.

No handshakes, Preuss asks: "Do you know Hardtloff?"

"You mean the Gestapo chief?"

"I mean the SA battalion leader, Hardtloff. He is asking you to see him."

"He is asking me to see him?"

At that even Elisa Kirschbaum begins to lose composure, and incidentally so does Meyer, asking to see him, just the tone, what a farce. Preuss says: "Yes. He had a heart attack in the morning."

The Professor sits down, baffled, looks over at his sister, she is now standing there as if made of stone, Hartloff had a heart attack in the morning.

"I don't quite understand." 
"You are to examine him," says Preuss. "Although I can imagine that the battalion leader's state of health doesn't exactly touch you to the core. For you there is no reason to worry."

"But. . ."

"But what?" Meyer asks.

More glances at his sister, a whole lifetime long she has managed to make unpleasant situations vanish from this earth, with her cold-bloodedness, with her foresight, with her inexorably keen mind, she has kept away all that is troublesome, and so one last glance at her.

"Dis-leur que tu n'en as plus l'habitude," she says.

"What's she saying?" Meyer asks Preuss, standing up to his full height.

"Please listen," says the Professor. "What you are asking of me is impossible. Under no circumstances could I justify it as a physician if after such a long time. . After all, I haven't treated a patient for more than four years."

Preuss remains admirably composed, he lays a calming hand on the shoulder of the belligerent Meyer, special mission, then he steps in front of the Professor, threateningly close. His eyes express reproach, not in an unfriendly or even angered way, but rather with compassion, as though they wanted to call to his senses someone who was behaving rashly, before it was too late. All the while he is saying: "I almost fear that you have misunderstood me, Professor. We did not come in order to ask you for anything. Please don't give us any trouble." "But I have told you. ..." 
"Is there anything you need to take along?" asks Preuss decisively.

Now the Professor finally understands that he no longer needs to look for excuses, those two have motives other than exercising their art of persuasion. The relative friendliness of this Preuss is his personal style and does not give you any rights. And so one forgets all "ifs" and "buts," one emulates one's sister. To be as unapproachable and as dignified as she, that at least, now at least, a whole lifetime one has admired her for it, even more than one feared her, some called her an oddba11. One will not offer two German creatures a drama of collapse, the question was: is there anything one needs to take along, one won't fall on one's knees before them, look how Elisa is standing there! That can't be imitated at will, but one can find quite ordinary gestures, an expression as on Wednesdays, as though something completely ordinary had happened, a dignitary has fallen $i 11$, one is to examine him, the usual stuff.

"Did we make ourselves clear?"

The Professor gets up, underneath the bookshelves are doors, he opens one, looks for his leather bag, round and brown, the doctor's bag. "It's in the closet," says Elisa Kirschbaum.

He gets the bag from the closet, opens it, examines its content, then holds it out to Preuss, who doesn't waste one look on it.

"Medical supplies."

"Fine."

Elisa Kirschbaum opens the closet a second time, a scarf, she holds it out to her brother. 
"I don't need it. It's warm outside," he says.

"You do need it," says Elisa Kirschbaum. "You don't know how chilly it is after eight."

He puts the scarf in his bag, Meyer opens the door, it's time to part now.

"Good bye, Elisa."

"Good bye."

That's what a farewell looks like.

Then in front of the house they get into the car, certainly according to a predetermined seating arrangement, Preuss and the Professor in back, Meyer in front next to the uniform. Elisa Kirschbaum is standing at the window, the whole street is standing at windows, but only one is open. The car turns in one swoop, driving over the flat curb, a pale blue cloud hovers for a few seconds. At the end of the street it turns to the left, in the direction of Hardtloff.

Preuss snaps open a silver cigarette case and asks: "Would you like one?"

"No, thanks," says Kirschbaum.

Meyer shakes his head without turning around, he looks at the uniform from the side, wondering what it thinks of this farce, but it simply grins ahead. Preuss listens to the two through the rearview mirror, not Kirschbaum, he is sitting as though any movement were sheer waste.

"How about putting your bag down," says Preus. "It's a fair distance yet." 
"How long, approximately?"

"Well, about thirty minutes."

Kirschbaum keeps his bag on his lap.

One arrives at the gate of the ghetto, stops, Meyer rolls down the window. A guard sticks his helmet inside and asks: "What's that bird you've got there?"

"Don't tell me you don't know him!" Meyer shouts. "That's the famous Professor Kirschbaum!"

Preuss holds out an identification card to the guard and says very formally: "Open the gate. We are in a hurry."

"Yes, yes, no harm intended," says the guard. He gives a hand-signal to a second guard who opens the barrier and pushes open the gate.

One drives on, now in the free part of the city, the street scene changes. Passersby without yellow stars must be catching Kirschbaum's eye, stores with displays, not exactly over-stocked, but customers coming and going, and above all trees bordering the streets, I imagine. The "Imperial" at the new market is showing a German film. Now and then a car in the opposite direction, a streetcar, soldiers in off-duty dress with two girls on their arm, Kirschbaum looks moderately interested, these scenes cannot tell him much, cannot conjure up memories, as with Jacob for example, since this is not his city.

"When I think about it, you should actually be glad to get your hands on a new patient again at last," says Preuss.

"May I inquire how you thought of me?"

"That was not hard. Hardtloff's personal physician was at wit's end, he insisted on the consultation of a specialist. But try and find 
a specialist in these times. We looked through the lists of residents and came upon you. The personal physician knows you."

"He knows me?"

"Not personally, of course. Only your name."

One enters the fancier neighborhoods, the houses are lower, standing further apart, more greenery, more trees too. Kirschbaum opens the leather bag, takes out a little vial, unscrews it, shakes out two tablets into the palm of his hand. Questioning glances from Preuss.

"For heartburn," Kirschbaum explains. "Would you like some too?" "No."

Kirschbaum swallows the tablets, screws the lid back on, back into the bag, he sits as before.

"Do you feel better now?" Preuss asks after a short time.

"They don't take effect that quickly."

They leave the city, another check, then it almost looks rural, Hardtloff found himself a secret little spot. Birch trees on either side, Preuss says: "You will of course be driven back when everything has been taken care of."

Kirschbaum now puts down his bag after all, the entire trip it was on his lap, so close to the end he puts it down after all, he leans back and breathes deeply.

"Would you give me a cigarette now?"

Preuss gives it to him, a light too, let's mention once again Meyer's poorly disguised amazement. Kirschbaum suffers a light coughing spell, calms down soon after, throws the half-smoked cigarette out the window. 
"On the other hand I can somehow understand your qualms," is how Preuss picks up the thread of a conversation that had long been given up for lost.

"I no longer have any qualms," says Kirschbaum.

"Oh yes, you do, I can see that you do. Your position is not exactly enviable, I can understand that. If you succeed in saving the SA battalion leader, you probably won't look very good as far as your own people are concerned. And if you don't succeed. . ."

Preuss interrupts his rather pithy analysis, the rest would be tactless and superfluous besides, Kirschbaum will have understood by now what value is attributed to Hardtloff's life. Meyer turns around for the first time on this trip, his face does not conceal the fact that he too knows the end of Preuss's speech and above all what his opinion of the rest of this speech is, with this in mind, as it were, he turns around for a moment. Kirschbaum pays no attention to him, he seems sufficiently preoccupied with himself. Preuss ventures one or two more trivial sentences, but Kirschbaum is no longer participating.

Then one arrives in front of Villa Hardtloff. A driveway through a luxurious park, a circular flower bed with a dried-up fish pond, all a little neglected but lavishly laid out, very lavishly.

"We're here," says Preuss to the still distant Kirschbaum, and gets out.

Hurrying down the front steps is the physician, a bald-headed short man in shiny boots and unbuttoned uniform jacket, looking unkempt like the garden. His haste indicates worry or fear, probably fear, he is the one who has the responsibility around here. For Hardt loff's health and, as we have heard for today's daring experiment. Still 
standing on the upper steps he calls down: "It's got worse again! Where have you been all this time?"

"We had to wait, he wasn't home," says Preuss.

"Quick, quick!"

Because there is no motion inside, Preuss opens the door on Kirschbaum's side and says again: "We're here. Please get out."

But Kirschbaum sits there as though he was still resolving things in his mind, he doesn't even turn his head toward Preuss. Last minute rebelliousness or the proverbial absent mindedness of the scholar, whatever it is, it comes at the worst imaginable time; one is getting impatient, Meyer would know for sure what was to be done.

Preuss grasps the Professor by the arm and says softly: "Don't make any trouble now, " propriety to the very end, and pulls him out with gentle force.

Kirschbaum's exit happens in a surprising way, he slides slowly towards Preuss, who is too surprised to hold on to him, Kirschbaum falls out of the car onto the unkempt ground.

"What's the matter?"

The physician crowds between the two, bends over the Jewish patient, and without any effort he reaches the obvious diagnosis:

"But the man is dead!"

He is not telling Preuss anything new, not now, Preuss takes the leather bag out of the car. Round and brown, the usual doctor's bag. "Is there anything you need to take along?" "Medical supplies." "Fine." Maybe one gave him the idea oneself.

Preuss opens the bag, finds the vial amongst the stuff. He gives it to the physician. 
"For heartburn," says Preuss.

"Idiot," says the physician.

Now for the explanation I had promised.

The one that is actually superfluous, but I imagine that many a person will suspiciously ask in what way I claim to have got into this car. It could hardly have been through Kirschbaum, so where was my informant sitting: and it isn't even an altogether unjustified question, from a certain point of view.

I could of course answer: I am not a commentator, I am telling a story that I don't understand myself. I could say: I know from witnesses that Kirschbaum got into the car, I have found out that he was dead at the end of the trip, the part in between can only have happened in that way or similarly, it isn't conceivable any other way. But that would be a lie, for the part in between could have happened quite differently, I even think more likely differently than like that. And that, I suspect, is the real reason for my explanation.

Well then. Some time after the war I took a trip to our ghetto, during my first vacation. My few acquaintances had advised me against $i t$, the trip would only ruin my entire next year, memories were one thing and life another. I told them that they were right and went. Jacob's room, the police station, the Kurlandische, Mischa's room, the basement, I looked at everything at my leisure, I measured, checked, or simply looked. I went to Jacob's cafe too, a shoemaker had temporarily moved in there, he said to me: "Until I find something better." 
It seemed to me that underneath the leather it smelled burnt somehow, but it didn't seem so to the shoemaker. On the next to last day of my vacation I started wondering, while packing my bags, if I hadn't forgotten something, I probably would never come back to this town, and now there was still time. The only thing that occurred to me was Kirschbaum's car ride, but that seemed to me to be unverifiable, and besides, I decided it wasn't so terribly important to the story for the sake of which I had come. Nevertheless that afternoon I went to the Russian headquarters, probably out of boredom or because I couldn't find a restaurant that was open.

The officer in charge was a woman of about forty who had the rank of lieutenant. I told her that I had been in the ghetto, that my father and Kirschbaum had been close friends before the war and that therefore Kirschbaum's fate interested me. I made a real Red Cross mission out of it. Then I explained to her the connection between Hardtloff and Kirschbaum and that all I knew was that Kirschbaum had got into the car, nothing else, and that was the truth. And that the two men that had come to get him were called Preuss and Meyer or something like that. And could she tell me something, if not about the Professor's whereabouts, then at least something about those two, that might be a starting point. She wrote down the names and asked me to come back in two hours.

After two hours I found out that Meyer had been shot a few days before the arrival of the Red Army by partisans during an ambush at night.

"And the other one?" I asked. 
"I have his German address here," she said.

I was already about to hold out my hand for the piece of paper, when she looked at me worriedly and said. "You are not going to do anything silly, are you?"

"No, no, what are you thinking of," I said.

She gave me the sheet, I looked at the address and said: "That's lucky. I too live in Berlin now."

"You stayed in Germany?" she asked surprised. "How come?"

"I don't know either," I said truthfully. "It just happened that way."

Preuss lived in Schoneberg, that is in West-Berlin. Nice wife and two children, his wife had one arm missing, I went there on a Sunday afternoon. When I rang the doorbell, a tall, brown-haired, good-looking man, a bit soft, hardly older than I, opened the door.

"You wish," he asked.

"Are you Mr. Preuss?"

"Yes?"

I said: "Pardon the intrusion. Could I speak too you for a few minutes?"

"Sure," he said, led me into the living room and, after some complications, sent the children out. On the wall hung a print of Durer's "Hands" and the photograph of a little girl in a mourning crepe. He invited me to sit down.

I first told him my name, which made him listen up, even though he didn't know what to make of it in particular. He began to understand 
a little better when I asked him whether I was correctly informed that he had worked for Hardtloff. I observed that he turned pale before he asked softly: "Why are you here?"

I said: "I am here because of a story. More precisely, because of a gap in a story, which you could probably close."

He got up, started rummaging around in a bureau, soon found what he was looking for and placed a piece of paper in front of me. It was his denazification document, signed and sealed.

"You don't need to show me that," I said.

He left the document lying in front of me anyway, until I had read it, then he took it, folded it up and locked it away again.

"Can I offer you anything?" he asked.

"No, thanks."

"Perhaps a cup of tea?"

"No, thanks."

He called: "Ingrid!"

His wife came in, one could tell that she still felt awkward with just one arm. He said: "That is my wife."

I got up and we shook hands.

"Would you please go down and get the beer keg? Sebald promised me two liters for the weekend," he said to her.

When she had gone out again I said: "Do you remember a Professor Kirschbaum?"

"Oh, yes, he said immediately. "Very well."

"Didn't you come to get him because he was to examine Hardtloff? Along with a certain Meyer?" 
"That's right. Meyer didn't last much longer."

"I know. But what happened to Kirschbaum? Was he shot when Hardtloff died anyhow?"

"What makes you think that? Those two never met."

I looked at Preuss, amazed, and asked: "Did he refuse to examine him?"

"One might call it that," he said. "He poisoned himself in the car. During the ride, right before our eyes."

"I can prove it to you," he said. "You'll need only ask Letzerich, he will confirm my words down to every detail."

"Who is Letzerich?"

"He was the driver at the time. He was there the whole time. Unfortunately I don't know his address, all I know is that he was from Cologne. But surely the address can be found out somehow."

I asked him to describe this ride to me in more detail, the result is well known. It took quite some time, his wife brought us some beer, I drank a glass, it tasted awful. I hardly ever interrupted him, because he remembered the details on his own. He especially emphasized the fact that Kirschbaum had offered him some of the tablets too. "And in fact, I sometimes have heartburn, not so rarely. Just imagine, if I had taken one of them!"

"That was a massive murder attempt," I said.

He went on telling: leaving the city, the last part of the trip, the last cigarette, Meyer's unequivocal glances, up to the villa, until the personal physician came, until Kirschbaum lay dead on the ground in front of him. How he had suddenly understood what had just happened, 
how he took the bag out of the car, the vial, gave it to the physician, how the physician said: "Idiot."

We were quiet for quite a while, he had to assume I was shaken up, but I was thinking what else I could ask him about. He had told it well, without gaps and vividly, I could find many obvious reasons why he remembered this ride so well.

At the end he desperately wanted to confide to me what he now thought of this wretched time, for once to unburden his soul of all that sentimental crap before an intelligent man, but I really had not come with that in mind. I said I already had stayed much too long, I still had things to do, he too no doubt, I got up and thanked him for his information.

"And remember the name, in case you want to check it out," he said. Egon Letzerich, Cologne, Rhine."

In the hallway we ran into his wife who was just taking the children to the bathroom. They were already wearing pyjama pants, bare on top.

"We11, what do you say?" Preuss said to them.

They both shook my hand at the same time, curtsied and bowed and said: "Good-bye, sir."

"Good-bye," I said.

The three disappeared in the bathroom, Preuss insisted on accompanying me outside. Just in case the front door was locked already. 
The front door was still unlocked. Preuss stepped onto the street in front of me, he took a deep breath, spread out his arms and said: "May is in the air again."

I had the impression that he was a bit tipsy, after all he had consumed two liters of lukewarm beer, minus one glass.

"Oh, by the way," I said, "What about his sister?"

"Kirschbaum's sister? We had nothing to do with her. I only saw her that one time. Was there anything else?"

When I was about to say good bye for good, he said:

"Would you answer a question of mine too?"

"Of course," I said.

He hesitated a moment before asking. "How did you get my address?"

"From the British Secret Service," I said. Then at last I left.

Hardtloff is dead of a weak heart, the news travelled as far as the freight yard. It must have happened last night, when we left the yard yesterday evening the flag on the brick house was hanging limply in its usual place, when we checked in for work this morning it was merrily fluttering at half-mast, so: some time in between. The flag itself is, of course, only a vague clue, it reveals nothing more than that someone high up has departed from us, without mentioning any names. The name was mentioned by a guard to another guard, that is, in the course of the morning Roman Schtamm evesdropped on that interesting conversation. He came to a pile of crates without any objectionable intention, the two were standing behind it talking about Hardtloff's death, it was a lucky 
coincidence. Roman took a little more time than usual in the lifting of the crate, he didn't manage it until the two guards changed the topic.

By now every one of us knows for whom the flag is flying at halfmast, Roman saw no reason to keep it to himself. One may well say we are bearing the news with equanimity, not much is going to change for us. If indeed ever, but not through Hardtloff's death, nevertheless there are worse things one could thing of. Only Jacob regrets that it was Roman Schtamm and not he who was listening to the conversation of the guards, the misfortune of the SA battalion leader would have made an excellent radio announcement. Not just because of its content. It would have been the first announcement which needn't be bought on loyalty and on faith, every single person would have had the possibility of convincing himself of its truth through his very own eyes and without any effort, its confirmation has been hanging from the flagpole since morning. To tell them now that one had already heard of Hardtloff's death on the early morning news would be pretty pointless, what's past is past, a radio has its pride, it doesn't limp behind the events.

When the whistle blows exactly at noon, Jacob once and for all bids this lovely thought farewell. The cart with the tin bowls is pulled up, we form the customary flawless line.

Someone behind Jacob asks softly: "Did you listen again last night?"

\footnotetext{
"Yes," says Jacob.

"Did they say anything about Hardtloff?"

"Nonsense. Do you think they waste their time with such small
} matters?" 
Someone in front of Jacob asks: "What stations do you listen to?"

"Whichever one," says Jacob. "Moscow, London, Switzerland, it depends on the weather."

"Never any German stations?"

"What for?"

"Do you listen to music sometimes too?"

"Rarely," says Jacob. "Only when I'm waiting for news. I don't have the radio for pleasure, you know."

"I would give anything to hear some music again. Anything," says someone in front of the one in front of Jacob.

The soup kettles take a long time coming, although the line, I swear, is straight as an arrow. One is quick to correct any irregularities on one's own, even those that are barely noticeable, but that doesn't produce the kettles this time either. Instead, the attic window in the brick house is opened, a hand commands silence, a voice shouts from above like the angry Lord himself: "A ten-minute break! Lunch is cancelled today!"

The cart with the bowls is pushed away again, the hungry snake line loses its orderly shape and disperses all over the yard. Spoons are neatly tucked back into pockets, muffled curses, maledicitions and angry looks, wait till the Russians show you, you dogs.

Near me Kowalski asks: "Are we not getting any food because Hardtloff is dead?"

"What do you think?"

"If you ask me," says Kowalski, "It's worth it."

He doesn't exactly provoke roars of laughter, no lunch, that's a hard blow, a blow in the stomach, so to speak. But good old Kowalski 
tries again with another modest joke: "Just imagine that each time one of us cashes in, the Germans get nothing to eat. That would be a fine famine!"

Nebich.

Wherever Jacob goes for the ten minutes, he is followed by a loyal flock of Jews, Kowalski joins them before he has even been missed. Jacob knows they are behind him, lunch is cancelled today, therefore a word from him must take its place. He goes to an empty freight car, they'll all find a place to sit there, a consideration which has long since become habit. Jacob doesn't feel quite at ease in his skin, he had planned to rest a little on yesterday's laurels, on the liberation of the little town of Tobolin. In the midst of our enthusiastic acclamation, Major Karthauser had placed his vigorous signature under the document of capitulation, the stronghold had fallen, but that was yesterday. No one could have suspected how desolate the next day would be, Jacob is sitting quite unprepared amidst his congregation.

Suddenly, I am told, as they are sitting there looking at him, for soon he must be starting his report, a nasty thought flashes through his mind, chasing away Tobolin and all victories. Suddenly he realizes that two news items have reached the yard today, although only one was immediately understood, Hardtloff. The other one, the bad one, remained unnoticed, even though it lay in the air, clear and unmistakable, only the effort had been lacking.

"Unfortunately the news isn't all that good," says Jacob worriedly.

"What news are you talking about?" 
"That Hardtloff died."

"Did you care for him?" they ask mockingly.

"Not for him," says Jacob. "But for Kirschbaum."

Unfortunately one is forced to share his opinion, it isn't easy, a conclusive connection, most of them are able to understand without further explanation. Conditions are not such that a Jewish doctor could outlive his Aryan patient by very much, least of all in this particular case. "What Kirschbaum?" someone asks, one can't know everybody. It is explained to him, big mind, an authority on heart problems, here Jacob's neighbor, was called in to cure Hardtloff. Then quite belated, a quiet mourning for the Professor, the ten minutes go by without any questions or victorious reports, Jacob might have wished for a different diversion. He feels a yearning for some kind of consolation, one can't just leave them sitting there like that, the old story about the secret German plans that fell into the hands of the Russians in the fortress of Tobol in crosses his mind for a second. But the whistle saves him from this stupidity by ending the lunch in its usual way, and an especially tasteless one it was today.

Despite Hardtloff's death, then, the day is taking a dreary course and continuing to do so. In the midst of work a tanker wagon pulled by two skinny horses appears, its sight is familiar, the chattering too, one can already hear it from afar. On the average it comes every third month, in summer less often, in the winter, when the ground is frozen, a little more frequently, but always on Mondays. Its visit concerns the little German woodshed with the heart on it, it can go without this for three months, no longer, or it overflows. 
A local farmer is sitting on the driver's seat, no one kows how he came upon this honor. We can't stand him. The Germans forbade him, when he appeared here for the first time, to talk to any one of us, and he strictly cooperates. In the beginning, long before Jacob's radio, we tried to coax a word out of him, we didn't know exactly which one, but some trifle from the outside. It could even have worked without any danger, but he sat on his seat with tight lips, keeping quiet and eyeing the guards in the distance; he probably feared for his head or his manure. Or he is an anti-Semite, or quite simply an idiot.

He stops his wagon behind the toilet. A German guard comes out of the brick house and mingles among the people who all start acting terribly busy, as soon as they can hear the ugly clattering. Because the work for which four people are now being recruited is no easier than hauling crates, you stink like a shithouse afterwards and have to wash up right away at home.

"You, you, you and you," says the German.

Schmidt, Jacob and two strangers walk to the back of the shed gnashing their teeth and begin with the filthy job. They take the two shovels and the two buckets hanging on one side of the wagon, Jacob and the lawyer lift the lid from the pit. Then they shovel the stuff into the buckets, the two others pour them out into the cauldrons. Schmidt's disgusted expression doesn't exactly make things easier, one has to reckon with three hours of work, halfway through one will switch around, shovel for bucket.

"Have you done this before?" asks Schmidt.

"Twice," says Jacob. 
"I haven't."

The farmer in the driver's seat is sitting with his back to them. He takes a little package out of his pocket, wax paper, unwraps it, bread with bacon. And bright sunshine to go with it, oblivious to the world he enjoys his lunch or snack, Jacob's eyes are running over.

The older one of the bucket carriers goes and begs the farmer for a bite, a whispered explanation about what happened to his own lunch hour, just a little piece of bread, we're not even talking about the bacon. The farmer seems hesitant, while shoveling Jacob notices his simple eyes scanning the yard for guards, none of whom is interested in the activities behind the heart shed.

"Don't be afraid," says our man. "You don't even have to talk to us. Just drop a piece of bread, by accident, do you understand? Nobody can do anything to you for that. I'll pick it up so that no one will notice. - Do you hear? No one, not even you will notice it!"

"Could you eat with this stench?" asks Schmidt.

"Yes," says Jacob.

The farmer reaches into his pocket again, takes out the wax paper, carefully wraps up the rest of the bread and bacon, stows it away. Either he is full, or he really has lost his appetite, just another big gulp from a green flask, he wipes his mouth with his dirty sleeve.

"Asshole," someone calls him, but not even this rude name brings him to life.

Shortly before the switch Schmidt begins to slow down noticeably in his scooping, finally he stops altogether, claiming not to be able to continue. That everything is turning in front of his eyes, black spots, he leans back sweating, against the back wall of the toilet shed. 
"That's because there was no lunch," says Jacob.

That's no help to Schmidt, big beads of sweat are rolling down his face, he tries to vomit but nothing comes out. Jacob shovels a bucketful for him, a timelag for the carriers ensues, no solution in the long run.

"You have to go on," says Jacob.

"That's easy for you to say," says Schmidt, panting, leaning against the wall and very pale.

"Either you go on, or you can lie down right now and die," says Jacob.

That's the last thing lawyer Schmidt feels like doing, he takes back his shovel and with weak knees he fills the bucket that has already been waiting for quite a while. He sighs, it looks like a desperate attempt and one has to fear that it will not succeed. The shovel pokes around at the surface, doesn't penetrate as deep as it should and is therefore retrieved from the muck only half full, surplus work for Jacob.

"By the way, I heard something about your Sir Winston," says Jacob, softly enough so that the farmer couldn't possibly understand a word, even if he had the keenest sense of hearing.

"About Sir Winston?" says Schmidt, weakly to be sure, but audibly interested.

"He has a cold."

"Anything serious?"

"No, no, just a head cold and stuff. He sneezed through half the interview." 
"A whole interview?"

"A short one."

"And what does he say?" asks Schmidt.

Jacob intimates that this is hardly the right spot for an open chat, the guards over there, right now they're still busy with other things. But in three hours one of them will come to check up, for sure, by then the pit must be emptied. So a report only if it can be camouflaged with work. Schmidt must see that, his grip on the shovel becomes firmer, the drops on his forehead stay the same, what does Sir Winston say?

Jacob tells it to him, the basement conversation between the reporter and the British Premier still sticks in his memory, though no longer quite fresh. The situation on the Eastern front, without mentioning any particular cities, is, in any case, desperate for the Germans, those are his very words, a big colorful bouquet of good prospects. And surely Sir Winston may allow himself an opinion, don't you think, with his knowledge? Of course there are still difficulties here and there, is there ever a war in which everything goes smoothly, I ask you?

And there are differences between Schmidt and Lena too, of course, and they have to be taken into account. One isn't sitting with a little girl in a basement at night, just for fun, so to speak, or out of love, one is stadning in the sunlight with a highly educated Schmidt, every word has to be weighed, in three hours the pit has to be free of muck. 
On the morning of the day that has been chosen for the march on the county capital Pry, the Russions won't quite get there, but will advance by a fair stretch, that's how Jacob has worked it out, on the morning of this promising day Mischa sees some commotion on his way to work. People are pointing in one direction and then in another, two are talking breathlessly, the others are listening worriedly, Mischa doesn't want to walk past without finding out details. Then the name of a street is mentioned, Franziskaner Street, Mischa grabs the first one by the arm, pulls him out of the confusion, would he just for heaven's sake tell him what is going on in Franziskaner Street?

That is quickly told, a misfortune has befallen it, Franziskaner Street is being sectioned off in three parts. They are going through it house by house, a while ago they were at number ten, in a few hours not a soul will be living there any more, to the camp or wherever.

"And the Russians are supposed to have captured Tobolin already," says the man.

Mischa dashes off, the fate of Franziskaner Street doesn't just move him in general, for Franziskaner Street is a very special street, Rosa lives on it. The man said a while ago they were at number ten, that is a few minutes ago, at this time Rosa should normally have been at the factory for some time already. Mischa reproaches himself for not simply having forced her to stay with him every night, especially this last one. He will go to her factory, the guard at the gate won't let him in but he can stay nearby. Until quitting time, Mischa will stand guard himself, for Rosa must be prevented from going home. Only God forbid that one be guarding an empty factory all day long, if Rosa 
left home on time she should be there, there is no other hope. Mischa runs, why so fast he doesn't know either, Rosa's quitting time is far off, he runs.

From the front of her factory, a textile plant made of grey brick, the world looks quite ordinary, Mischa is standing on the other side of the street, no one else besides him. He is preparing for a long day, but it turns out to be much shorter than expected. Out of the factory steps a Jewish girl, Mischa asks himself how come she is getting out during work hours, she strolls aimlessly across the street, right past him. Mischa stands there hesitating until she has almost reached the next corner, then he follows her. She soon notices, turns her head flirtatiously, once and then again, such a blue-eyed, broad-shouldered young man is rare in our ghetto, and in broad daylight. She immediately slows down her step, she doesn't object to his catching up with her, and that is what finally happens, right after the corner he is standing beside her.

"Excuse me," says Mischa. "Do you work in this textile plant?" "Yes," she says, smiling.

"Do you happen to know if Rosa Frankfurter is still in there?"

She thinks for a few seconds before saying: "You are Mischa, aren't you?"

"Yes," he says. "Is she in there?"

"She left a few minutes ago. They told her she could go home for today."

"How long do you mean by 'a few minutes'?" he asks, his voice shrill already. "How long, exactly?" 
"Maybe ten," she answers, surprised at his sudden agitation. Again he dashes off, calculating feverishly that it should be possible, if it's true about the ten minutes. From here to Franziskaner street it takes Rosa a little less than half an hour, more if she is strolling, and surely she is not hurrying. They told her she could go home, without giving any reasons, the bastards, so there is no need to hurry.

All of a sudden Mischa turns around, hurries back, a careless mistake must be corrected, an unforgivable one. The girl is slowly walking towards him and is smiling again.

"Were you sent home too?" he calls to her from far away. "Yes."

"Don't go home! Hide!"

He still hears her asking: "But why?"

"Because Franziskaner street is being deported!"

"But I don't even live in Franziskaner street. I live in Zagorsk Street."

That long-winded conversation is taking up much too much of his time, so it's Zagorsk Street too, he told her all he knows. Let her make sense of it, save her life or not, if she is smart she'll stand in front of the factory and tell everyone who is being sent home: "Don't go home, hide, no matter where you live!" That is going around in his head long after he has started to run again, to run after Rosa. And the fact that Franziskaner and Zagorsk streets don't even meet anywhere, between them lies Blumenbinder Lane which has few houses, mostly storage places that are unused today, except for a few. And around every new corner he looks for Rosa, maybe she isn't even taking the shortest 
route, maybe she is taking a walk in this weather and wants to enjoy the free day. If she is really taking a walk, he would certainly arrive in Franziskaner Street before her, he could stand at one end and intercept her. But of course only at one end, Franziskaner Street has two, at which one are you going to stand since there are so many, and at this time of day there is no way you will find a helper. A new glimmer of hope surges up for a few moments, Mischa banks on Rosa's instinct for survival. No matter at which end she appears, she will realize what is happening to her street. Maybe then she'll turn around, run to his place, hide in the courtyard and wait until he comes home in the evening with the key. But Mischa doesn't rely on that too much, he knows her too well for that, crazy Rosa won't be able to chase those thoughts of love for father and mother out of her head, all that useless girls' stuff. At most she will muster up a second of hesitation at the sight, then she will run crying to her destruction, she will run to where her parents are, who can well do without her, and thereby help no one.

All these deliberations come to an end when he finds her at last on a long, perfectly straight street. On Argentina Avenue, whose linden trees have been carefully sawed off, close to ground level, and which therefore offers a wide field of vision. Practically no people, he recognizes her reddish brown dress when it is yet just a dot, then her blue kerchief, her gait, slow as predicted, Mischa thinks: What luck.

A few minutes behind her he stops running, quietly follows her for a few steps, Rosa is looking at the pretty old gables, a merchants' area in former times, Rosa is taking a walk. His last thoughts before he makes himself known, his behavior must be casual, he is just on his way 
to her house because he found out that the factory gave her the day off. Nothing about terrible worries, not a word about the fate of the residents of Franziskaner Street, or else this parental love stuff will pop into her head.

He is about to cover her eyes from behind with his hands and to ask her in a disguised voice to guess who; that would be an innocent beginning. He notices that his hands are sticky with sweat, his face too, he wipes it dry with his sleeve and says with forced cheeriness: "Fancy meeting you here."

She turns around quickly, startled at first, then she smiles, the prettiest girls smile at Mischa. Rosa asks: "What are you doing here?"

"And what are you doing here?"

"I am going home," she says. "Imagine, I hadn't been at the factory for one hour when they told me I could leave."

"And why?"

"Don't ask me. They simply said I could go home. A few others too, but not everybody."

"It was sort of that way with me," says Mischa.

"You got off today too? The whole day?"

"Yes."

"Nice," says Rosa.

She takes his arm, a lonely passer-by admires this picture of young love.

"Let's go to my place," says Mischa.

"But how come you are here all of a sudden?"

"Because I wanted to pick you up at the factory. When they gave me the day off, I thought maybe they're letting you off today too." 
"You're a smart kid."

"But you had just left. A girl told me, a pretty little thing with red hair."

"That was Larissa," she says.

They walk to his apartment, leisurely, since that direction doesn't worry him, Franziskaner Street is completely avoided. Rosa tells about Larissa, and that she sometimes talked to her about Mischa, he wouldn't be mad at her for that, would he, they sew at the same table and the day is so long. Larissa is quiet but deep, one shouldn't be fooled by her dreamy eyes. She too, by the way, has a boyfriend, his name is Najdorf, Josef, she calls him Jossele, he works at the tool factory, Mischa probably doesn't know him. They live in the same house, Larissa has a mother too and two grown-up brothers, a funny thing happened one time with the two brothers. They once beat up on Josef Najdorf when they caught him in the attic with their sister, and what do you thing they were doing? Kissing, of course, but Larissa told them off pretty good. Now they're nicer, they've come to realize that she isn't a little kid any more, Jossele is even allowed to visit her in their apartment sometimes, for a chat, of course. And suddenly, right in the middle of all this wonderful gossip, Rosa stops and asks: "How come they are giving us the whole day off, anyway?"

"How should I know?" says Mischa.

"But there must be a reason."

He shrugs his shoulders, he had hoped she wouldn't bring it up, he'll have to put off answering that one for a while, but of course she is right, it is strange indeed. 
"Do you think it has anything to do with the Russians?"

"With the Russians?"

"Well, yes. If they feel that things are hopeless for them, then they might want to ingratiate themselves a little with us," says Rosa. "Don't you understand? For afterwards."

"Maybe," says Mischa, he can't come up with a better explanation either.

To his place then, at a strolling pace, Rosa proves to be more talkative than ever before in all her carefreeness. Mischa lets her flow of words run freely, she hasn't shot her wad with Larissa, no way, Klara, Annette and especially Nina are having affairs too, and how, her own father is beginning to foster timid hopes for the future. Two evenings ago he put a strange piece of paper on the table, says Rosa. On it, divided into three groups, were theater parts he hoped, God willing, to play some day, the director had excluded him from them for long enough. Rosa doesn't know any details, she understands too little about theater for that, but there must have been at least twenty. At the door something unpleasant occurs to Mischa, no work means no lunch today, he asks Rosa if she happens to have her food stamps with her. Unfortunately they're at home, that's all we need, he thinks. Should she rush home and get them, no she shouldn't, he hands her his key, he'll be right back, he is taking his own stamps.

"At this time of day?" asks Rosenek, the well-nourished one. His scales are suspected of inaccuracy in one direction only, how else could he have got his paunch? He certainly tries to hide the little monster under much too large a smock, but smock and Rosenek are transparent, no 
smock is large enough to cover his fat cheeks.

"Day off today." says Mischa.

"Off? What do you mean?"

"Off."

Mischa puts the food stamps on the counter in front of Rosenek, all of them.

"It's only Tuesday," says Rosenek surprised, a cautious warning. "Doesn't matter."

"You must know."

From a drawer dusty with flour Rosenek takes a round loaf of bread that doesn't smell of bread at all the way they used to, puts it on the counter, saws it with his serrated knife, groaning, then onto the famous scales, the dishonest weights lined up like organ pipes.

"Please weigh it well," says Mischa.

"What does that mean? I always weigh well."

Mischa isn't going to start splitting hairs, that won't lead anywhere anyway, he says: "Weigh it especially well. I have company."

"Company? What do you mean?"

"Company."

Rosenek discovers his heart, he gives Mischa the other so-called half of the loaf without putting it on the scale. And two pockets full of potatoes, because Mischa has nothing for carrying, a bag of pea-flour, sausage, in appearance more than in essence, and a little package of malt coffee.

"On the stamps it says something about lard as well," says Mischa. "Does it now? does it also say where I am supposed to get it?" 
"Mr. Rosenek," says Mischa.

Rosenek looks at him as though faced with the hardest decision of his life, you'll be the end of me yet, boy, Rosenek asks: "Do you need the coffee?"

"Not so badly."

Rosenek persists another while in his unhappy pose, finally he takes the little package of coffee from the counter, goes into a room adjacent to the store. When he comes back he is carrying a little piece of wax paper in front of him, at first sight it looks like just a pice of folded wax paper, but then one can see that something is wrapped up in it. Lard, Rosenek cut it off his own belly, judging by the expression on his face.

"For a special favor," says Rosenek. "But for heaven's sake don't tell anyone."

"Why should I?" says Mischa.

Mischa arrives upstairs generously loaded down, Rosa marvels at what he has brought, she has opened the window wide.

"Otherwise the sun will think no one is home and go away again, Mother says," says she.

Mischa stores Rosenek's presents in the cupboard, cleans his pockets of potato dirt. Rosa calls him to the window, her voice worries him. He leans out beside her, a grey procession is approaching, still small and indistinct. As yet all you hear is the barking of dogs now and then and quite unnecessarily, for no one is stepping out of line.

"Which street today?" asks Rosa.

"I don't know." 
He pulls her away from the window and closes it, but he can't prevent her from standing behind it waiting for the procession to pass. Rosa says: "Let me. Maybe there are people I know among them." "Are you hungry?" he asks. "Should we fix ourselves something?" "Not now."

He spares himself any further offers. He knows that she will answer everything he could possibly suggest to her at this moment with a: "Not now." Only force can separate her from the window, silly actually, for she has no idea whom she is about to see in that procession, but she believes that on such occasions she mustn't bury her head in the sand. A kind of basic rule for Rosa, that's how she is. The simplest would be to grab her, throw her on the bed and start smothering her with kisses as though overcome by a sudden urge. Mischa is already taking the first step in that direction, but at the second step he loses his nerve, for Rosa knows him too well, she would immediately see through the lie. One will just have to leave her standing there until that terrible sight, she won't be spared that. He sits down on the bed trying to look composed, which doesn't make one bit of difference, since Rosa is constantly looking out. Her forehead is leaning against the window pane, pushing against it, in order to catch a first glimpse of the transport, a little spot of steam forms on the glass, she is breathing with her mouth open, as excited people do.

"Come on over here," he says.

Did those idiots have to pick his of all streets, aren't there enough other ones, Mischa feels like getting up and going out into 
the hall or at least in Fajngold's half of the room, which, of course, got its old face back one day after Rosa's intervention, what in the world is she going to do? The barking of dogs is getting louder, whenever it stops for a moment one hears steps, even a single voice calling: "Lively, step lively!"

"Mischa!" says Rosa softly.

"Mischa!" she screams seconds later. "Mischa, Mischa, Mischa, that's our street!"

He is standing behind her now, the thought that her parents must be in this procession hasn't hit her yet. She whispers the names of the neighbors, one after another, as she recognizes them, each one is holding something in his hand, a bag, a suitcase, a cloth stuffed with things that had to be brought along. Mischa finds time to look for the Frankfurters, he discovers them even before she does, Felix Frankfurter with his customary scarf slung around his neck. His gait suggests hope somehow, his wife, a head shorter, beside him, she is looking up to their window, Mischa was never any kind of a secret.

Rosa is still whispering names, her mother's glances give Mischa the last push he needs. He clutches Rosa in his arms and carries her away from the window, he wants to lay her on the bed and keep her there by force, but it doesn't come to that, they fall down on their way, since Rosa is resisting. He lets himself be hit, scratched, and pulled by the hair, all he does is clutch her body, they lie on the floor for half an eternity. She yells for him to let go of her, maybe twenty times she yells nothing but: "Let me go!" Until no more barking is heard, no footsteps, her slaps are getting weaker and finally stop. 
Carefully he lets go of her, ready to grasp her again any moment. But she lies there motionless, her eyes closed and breathing heavily, as after heavy exertion. There is a knock on the door, and a woman from the building asks if she can be of help, it sounded as though someone had been screaming.

"No, no, everything is OK," says Mischa through the closed door. "Thank you."

He gets up and opens the window, otherwise the sun will think there is nobody home and go away again, as we have heard, the street is quiet and empty. He looks out for a long time, when he turns around Rosa is still lying on the floor, her position has not changed.

"Come, get up."

She gets up, he has the feeling not because he said so. Not a tear has been shed yet, she sits down on the bed, he doesn't dare talk to her.

"You are bleeding on your neck," she says.

He walks towards her, crouches down in front of her, tries to look at her, but she looks past him.

"That's why you picked me up," she says. "You knew it."

He is startled when he realizes how much reproach there is in her words. He would like to explain to her that there was no more time to warn her parents, but at this moment she will not accept any reason.

"Did you even see them?" he asks.

"You didn't let me," she says and at last starts to cry.

He says that he didn't see them either, not even at the very end of the procession, perhaps they sensed the danger in time and managed to 
save themselves. He knows how ridiculous that is, after three words he notices how pointlessly he is lying, but he finishes the sentences as if he had been wound up.

"You'll see them again, for sure," he adds. "Jacob said. . ."

"You are lying!" she yells. "You are all lying! You talk and talk and nothing changes!"

She jumps up and is about to run outside, Mischa doesn't manage to grab her until after she has already yanked the door open. In the hallway the woman straightens herself up from keyhole height. She asks: "Is there really nothing I can do to help?"

"No, damn it!" Mischa yells, now he is yelling to.

The woman backs away insulted, one may assume that her eagerness to help has been crushed forever, at least as far as this loudmouth is concerned. In any case, it looks as though Rosa has come to her senses throught the appearance of a third person, she goes back into the room without Mischa's having to force her. He shuts the door, he fears the silence. That's why he immediately starts taking possession of Fajngold's fallow half, the dresser back to the wall, exactly in front of the large square on the wallpaper that still looks so clean, the curtain off the ceiling and back in front of the window. Because Rosa is going to live here now, at least that much is clear.

"Did you ever hear anything about the deportation?" asks Mischa. "No," says Jacob.

"They didn't just clear out Franziskaner Street. They were also in Zagorsk and. .." 
"I know," says Jacob.

They walk silently a few steps on their way home from the freight yard, they have already gotten rid of Kowalski at the previous corner. He restrained himself with his questions in Mischa's presence.

At the yard five have been missing since that day, maybe even more, we only miss the five that we knew personally. Jacob had already thought there were six, he had included Mischa in that number because he hadn't come to work that day, luckily that was an error.

"How is it with Rosa?" Jacob asks.

"How should it be?"

"Are you two managing with the food?"

"Wonderfully!"

"She can't get more stamps now, can she?"

"You're telling me!"

"Couldn't somebody in your building help out? That's the way it is with me and Lena too. Kirschbaum always used to give something for her."

"I no longer believe in a happy end," says Mischa. "Now they are going through every street, one by one."

It seems to Jacob as though there was a reproach barely hidden in his voice.

"Maybe," says Jacob. "But think about it. The Germans are in a panic! The transports are the best proof that the Russians must already be very close! If you look at it that way, they are even a good sign." "One heck of a good sign. Try to explain that to Rosa some time." 
On one of her deadly afternoons of boredom and weeping Rosa leaves the apartment, even though Mischa had strictly forbidden it to her. He would have preferred to have locked her inside, no matter how much she may have protested, he hadn't done so only because the toilet is out in the courtyard.

She has no particular destination, she just wants to walk around a bit after a long week in jail. The dangers Mischa is always talking about seem exaggerated to her, she is no safer in his room than anywhere else, that house could be next any time as well. And who should recognize her, there are hardly any acquaintances left, the street patrolling doesn't start until evening, right around curfew time. Anyway, she really doesn't care much about all that, and anyway Mischa needn't find out about her walk, she is not planning to stay away long. It doesn't have to be the absolute truth if later on, when he turns out to be home long before her after all, she tells him that she happened to have the key to her apartment with her. And that without really wanting to, she suddenly found herself standing in Franziskaner Street, her feet just went that way out of old habit, she says.

The street strikes her as unreal in its emptiness, it is even being avoided by through-traffic, as if the plague had raged in it. Rosa looks into abandoned ground-floor rooms, into rooms of people she had greeted only a few days ago, behind a window she discovers a boy. He is about fourteen years old, he is kneeling in front of an open closet, and in great haste stuffing into a knapsack everything he can get his hands on: dishes, bed linen, a pair of pants, a wooden box without even checking its content for usefulness. Rosa watches him, 
wide-eyed, the only living creature besides herself. The closet seems completely empty, but the knapsack isn't full yet, the boy stands up and looks around the room searchingly. That's when he sees those big eyes behind the window pane, for the first moment he is frightened, then he sees the star on Rosa's chest too, and an encouraging grin spreads over his face. He is probably suspecting harmless competition.

Rosa hurries on, she wonders if by now one of those has been to her apartment too, she knows no other word, a looter. She feels no anger, but understanding alone isn't enough, she finds it unpleasant that behind those walls another secret life exists, one which can't be seen at first glance and which is gradually wiping away all traces.

Quietly she opens her outside door and listens, her heart pounding. She would love to have Mischa along, maybe he could have been persuaded, but now she is here without him. One can never be sure, but after a good while of silence she assumes that there is no one besides herself in the building. She quickly walks up the two flights of stairs, before she unlocks the door she looks through the keyhole. Then she is standing in the room, it looks very tidy. The dust hasn't had much time to settle yet, the four chairs are neatly placed around the table, on it there is a yellow tablecloth with a fringe on each long side. The faucet is dripping. Up until now no one with a knapsack has been here, Rosa can see that at first glance, and also that her parents must have departed without haste.

First she looks around for some kind of message, an idea which has hit her just now, she remembers that her mother never went away for one second without leaving a message. But this time she broke that old 
habit, it seems, for no piece of paper with writing is to be found, and anyway, what could it say but: "I don't know where to or for how long." Then Rosa searches once more, not for a message any longer, for nothing in particular. Mischa tells me she is a sentimental little thing, she wanted to gain an impression, what had her parents taken along? She is probably crying her eyes out while doing it, the brown and white checkered shopping bag is missing and the black cardboard suitcase, no other containers. Since Rosa knows the whole inventory by heart, by the end of her search she would be able to draw up a list of what was taken along. Even the album with photos and reviews, the book of the true life of Felix Frankfurter.

Her own things lie untouched, amidst her stuff the food ration card, part of it already expired. Rosa puts it in her pocket, otherwise there are no items she is especially fond of. She forces herself to practical considerations, there is a briefcase around, in it she puts her second dress, underwear and stockings, her coat comes last. While doing that she is amazed that she is able to think ahead to next winter. With the coat in it the briefcase won't close any more. Rosa is about to put it on, but then she would have to take the stars off her dress and sew them on the coat. So she stuffs it into the briefcase after all and ties the coat belt around it. If she runs into the boy on the street, he will surely envy her her rich booty.

Rosa turns the faucet off harder, she is finished here. When she goes she leaves the key sticking in the door, for the boy or for someone else, as a kind of final statement.

"You can guess ten times," says Mischa to me, "And you won't hit on where she went now." 
Rosa goes to visit Jacob, whom she doesn't know, except from Mischa's reports, but quite well from those. Since Bezanika there has not been one evening spent together in which they haven't talked about him, about his radio, about his courage, about the Russians' advances at the front. Rosa had asked at the time, when the biggest joy about the original news had worn off, why this Jacob hadn't started spreading the news until now, one has been living in the ghetto for three years already, and if he is keeping a radio hidden, then he has had it from the very beginning.

"The Germans have probably been advancing the whole time up until now. Was he, perhaps, to report that things were getting worse from day to day?" Mischa answered her, and that sounded convincing.

There she is, standing in front of the door, not out of vindictiveness or out of personal anger, she tries to tell herself. Surely he is nice and friendly and wants the best, but these promises that keep sounding happier from day to day and then the empty room on Franziskaner Street, the whole neighborhood even, she will ask him how one is compatible with the other. She will raise doubts as to whether it is permissible to kindle such hopes in a situation like hers, don't start talking to me about your radio, it can tell whatever it likes, all you need to do is look around you.

Rosa knocks several times, in vain, why hadn't it occurred to her before that Jacob must get home at about the same time as Mischa. This waiting makes her unsure, once she does stand face to face with him her head will feel as if it had been hollowed out. She could still leave and perhaps be at the apartment before Mischa, thus avoiding a quarrel 
which otherwise would most certainly take place. The longer she waits, the more she has to admit to herself that she has come with a pretty foggy purpose. Jacob will keep referring to his radio, no matter what her reproaches may be, she had hoped that they would all survive these times unharmed, now it has turned out differently, that's what her whole reason really amounts to. "She plays faster than she thinks," her father once said after a game of checkers, her father. The thought occurs to Rosa that Jacob might be spreading different news than what he hears on his radio.

There is Lena at the end of the hallway, fresh from the street and from Rafael's, she sees a young woman with a stuffed briefcase in front of a certain door, and, being curious, she comes closer. They look each other over for a bit, neither one as yet harboring and suspicions. Lena asks: "Do you want to see Uncle Jacob?"

"Yes."

"He should be back soon. Wouldn't you rather wait inside?"

"Do you live here?" asks Rosa.

Instead of an answer, Lena takes out the key from behind the doorframe, unlocks the door, waves her hand invitingly and a little proudly. Rosa hesitantly enters the room, a chair is pushed towards her immediately, she has fallen into the hands of an attentive hostess. Lena sits down too, they continue to look benevolently at each other.

"You are Lena, right?" says Rosa.

"How do you know my name?"

"From Mischa," says Rosa. "You two know each other well, don't you?"

"Sure. And now I know who you are too." 
"I can't wait to hear it."

"You are Rosa. Right?"

They tell each other what they already know about one another, Lena, by the way, is still mad at Mischa, because the whole time she was sick in bed he didn't once come to see her, always just warm regards through Jacob. Rosa looks around unobtrusively, of course she hadn't expected the radio to be standing around in the open, to the joy of every visitor who happened to drop by.

"What is it you want from Uncle Jacob?" Lena asks once they have exhausted all other topics of conversation.

"Let's just wait until he gets here."

"Are you supposed to deliver a message from Mischa?" "No."

"You can go ahead and tell me. He doesn't keep any secrets from me."

But Rosa, nonetheless, has no such intentions, she smiles and is silent, so Lena chooses the long way around.

"Have you ever been to our house before?" she asks.

"No, never."

"Quite a few people have been coming to our house lately, you see. And do you know what they want?" Lena inserta a pause, during which Rosa is supposed to become aware of this very special proof of confidentiality, before she reveals: "They want to hear news. Is that why you have come too?"

Rosa's face loses its smile, that's certainly not why she is here, quite on the contrary. By now she is even regretting that she came at 
al1, and increasingly so since the very first moment; she feels she is in the wrong place with her despair, things are honest around here and in the best of faith. She asks herself what she would do if Jacob came in now and told her that the transport with her parents had met their liberators on its way to so and so. And she doesn't dare come up with an answer, not even to the second question as to whether up until now she had been lying to herself about the real reason for her coming, she wouldn't entirely put it past herself.

"What is it?" asks Lena. "Is that why you have come too?"

"No," says Rosa.

"But you've heard about it too, haven't you?"

"About what?

"That soon everything will be different?"

"Yes," says Rosa.

"Then why aren't you happy?"

Rosa straightens up in her chair, now the point has been reached where one either turns back or tells the truth, but what is the truth, aside from her misgivings. She says: "Because I don't believe it."

"You don't believe what Uncle Jacob is telling?" asks Lena in a tone of voice as if she hadn't heard it quite right.

"No."

"Then you think he is telling fibs?"

Rosa likes that way of putting it, it takes ingenuity in these circumstances, she would like to chat with this lovely girl about lovely things. By no means must she continue in this same direction, how could she do that with a child. Without stating any conclusive reasons, she 
is suddenly convinced that she has made a mistake, which, hopefully, will remain without consequences. She can't just get up and leave, Rosa sits there waiting forlornly, not for Jacob anymore but for the opportunity of casually ending this misconceived visit. but that opportunity is slipping further and further away, after a second of anxiety Lena is showing a zeal that seems almost frightening. Because her Uncle is anything but a liar, Rosa hasn't said that, oh yes, that's just what she did say, how can one assert such things? When she herself had heard on his radio that the Russians will soon be here, with her very own ears, what do you say about that? A man with a very deep voice told it to another man, she forgot his name, but she remembers the voice exactly, he said literally that the mess will soon be over, a few more weeks at the most. Had he maybe told fibs too, how did Rosa ever get the idea, anyway, to charge her uncle with lying, she should go ahead and wait for him, he'll have the right answer for her.

Before everything has been uttered, indignantly, words flying out, Lena interrupts herself and stares past Rosa, startled. Rosa turns her head towards the door. Who should be standing there but Jacob, stonefaced, as they say, one hadn't even felt a draft.

Rosa gets up, however much or little he has heard, she feels uneasy, his eyes look so terrified. She walks to the door, her head bowed low, no opportunity for a gracious exit will present itself now, she has started something. Jacob steps aside for her by half a step, but back to her chair again one more time, for the briefcase is lying on the floor, forgotten. Throughout the whole long hallway Rosa never dares to turn around. In front of the staircase she does, though, Jacob 
is still standing motionless, staring after her, soon the little kid will tell him what he must know already.

Let's stick with Rosa, she goes out in the street as dusk is beginning to fall; there the next hurdle is waiting. At first glance wild upheaval, the Jews are again running into their houses for cover, first Rosa can't figure out why. Then she sees a car approaching, a little dark green truck, on the running board is a man in uniform. Rosa runs back the few meters into Jacob's house, caught up in the panic and without thinking, she leans against the wall, keeping her eyes closed. She opens them when she hears hurried steps, an old man stops beside her, panting, he's come off the street too.

"What do they want, Miss?" he asks.

Rosa shrugs her shoulders, soon the car will drive by and be forgotten, the scene with Mischa is already waiting. The man suspects that it is a matter of utmost importance, otherwise they would have come on foot, as one hears every few days. To the horror of both of them there is a screeching of brakes, the frightened old man grips Rosa's arm so that it hurts her.

Two men in uniform come into their very hallway, leather straps under their chin, the old man will not let go of Rosa's arm. Outside the motor is still running, at first the Germans think they are alone in the semi-darkness, but when they are already almost as far as the stairs, one of them says: "Look!"

They turn to the two figures against the wall, Rosa seems to interest them more than the man, but maybe she is imagining it. They come a few steps closer, then one of them waves his hand and says: "No, no." 
The other one says: "Get away from here."

Then they go up the stairs, their noisy boots startle the entire building. One hears a door banging, excited voices from everywhere interrupting each other, when calmness would be so much more appropriate, a child is crying.

"Come out!" whispers the old man.

Rosa runs behind him, in the door he hesitates because he is afraid of the car, but pass it they must if they mean to obey the German's command.

"OK, go on," says Rosa.

They hurry across the street towards the house opposite them, the door is already being opened for them from inside. The old man sits down exhausted on the lowest step, he moans as though he had run around the entire block and rubs the area around his heart. Besides him Rosa sees three other men and a woman in the hallway, which is even darker than the first one, she knows no one. She looks over to the door, it is made of metal, a fourth man is standing by the keyhole, a fairly young one who is reporting to all of them.

"Nothing yet," he says.

"Who are they looking for in there?" the woman asks the old man. "Beats me," says the old man and keeps rubbing his heart.

"Does anyone special live there?" a bald man asks.

At first he gets no answer, they are all on their way home from work and strangers to this street, until Rosa says softly: "They've come to get Jacob Heym." 
Who is Jacob Heym, what Jacob Heym, the lookout at the keyhole straightens up and asks: "Jacob Heym? Is that the one with the radio?" "Yes."

"Fine mess," he says without a great deal of sympathy, Rosa feels. "It had to leak out some time."

Whereupon the old man on the steps gets furious, which surprises Rosa, he seem preoccupied with his fear and his heart alone, now his veins are swelling up: "Why did it have to leak out, you greenhorn? Huh, why? I can tell you why it leaked out. Because some no-good tattled! That's why! Or do you think it just happened?"

Embarassed, the greenhorn swallows the reprimand without contradiction, he bends back down to the keyhole and says after a short pause: "Still nothing."

The old man motions Rosa towards himself with a nod of his head and when she is standing in front of him, he moves over a little. So she sits down beside him.

"Do you know him?" he asks.

"Whom?"

"This Jacob Heym?

"No."

"Then how do you know that he lives there?"

"From acquaintances."

"They are still in there," the greenhorn reports.

The old man remains silent for a few seconds, then he says in the direction of the door: "When they bring him, be sure to tell me. I want to know what he looks like." 
That strikes Rosa as being in bad taste just then, later on it doesn't.

"He risked a lot," says the old man admiringly, turning back to Rosa, who nods. And asks herself how she will ever tell Mischa, let him get thoroughly angry about the visit to her apartment, she won't be able to hide that, even if she wanted to, the briefcase and the ration card would give it away without her confessing. But she'd rather not mention Jacob, she doesn't dare face Mischa with that, not just now. And sad as it is, the meeting with Jacob can easily be kept a secret, Jacob will not be in a position to call her a liar in front of Mischa.

"Maybe he isn't even home," says the old man.

"He is home," says Rosa without thinking.

The old man looks at her surprised, a question all ready in his glance, but he doesn't get to ask it, because the greenhorn calls from the door: "You were wrong. They are bringing out a woman!"

Let's permit ourselves a freer view, let's go out on the street, the woman they are leading away is Elisa Kirschbaum. She has to pay for her brother's incapacity, for the fact that, contrary to their expectations, he was not capable of curing the SA battalion leader, it took them long enough to think of this.

One had already feared some such outcome in the building for quite some time, it's not that hard to add two and two together, someone had thrown the word "genealogical responsibility" into the conversation, a word that had not been known to us before. The very evening of the day when the flag at the freight yard was flying at half mast, Jacob had gone to Elisa Kirschbaum. He brought up the question of whether it 
surely had, at leat for a while, until one could determine whether the threat of reprisal was indeed imminent. For, painful as it might be, one had to assume the worst for her brother, and if the miracle were to occur, if despite everything he should return unharmed, Jacob declared himself willing to notify her immediately. But she would not hear of any of that, she said to Jacob: "That is very kind of you, dear Mr. Heym. But please let that be my worry." As if she still held a trump in her hand of which no one had any idea.

Now she is walking along in front of the two Germans, hurriedly, so as to avoid any pretext for pushing or touching her. And hurriedly also, as Jacob behind his window suspects, in order to spare the street, which, despite its apparent desertedness, is full of hidden eyes, a big spectacle. The display of concentrated force radiating from the two behind her seems exaggerated for such a dainty charge, Elisa Kirschbaum stops behind the truck without looking around at her escorts. One of them opens the tailgate, on the inside is a little ramp, she is about to climb up. At that point the truck starts up, Elisa Kirschbaum steps into a void and falls onto the street. The truck merely turns around in order to stop on the other side of the road, the driver is already sticking his head out the window. Jacob's vantage point is so far away that he can't make out the faces of the men, later on the more immediate neighbors relate that the Germans were smirking as if it were a well-worn prank. Elisa Kirschbaum gets up right away with amazing agility, she stands ready once again, even before the truck has finished turning. He has to take two runs at it. Then she steps up, it is 
rather high for her, despite all her efforts she gets a push. The two climb up in back as well, the tailgate is pulled in, Elisa Kirschbaum has disappeared for good behind the dark green tarpaulin. The truck drives off, after a safe delay many front doors are opened. And the narrow sidewalks are gradually filled again with silent and with debating people, most of whom are, as we know, on their way home from work and strangers in this street.

Meanwhile, according to the radio, the Red Army is knocking at the doors of the county capital Pry. Pry can't be compared to Bezanika, everyone can imagine Pry, with Pry no one has to ask where exactly that is. Pry is one hundred and forty-six kilometers away from us, most of our residents know the little town from occasional visits. A few have even lived there and were moved here after the start of the war, for thanks to its fortunate social makeup, Pry does not have a ghetto of its own.

The position of the Russians becomes the subject of an altercation, Kowalski has a fight with one of his three roommates whose names are unfamiliar to me. Now, as the good-natured Jacob and I myself along with him know full well, it is the easiest thing in the world to be of a different opinion from Kowalski, but in this particular case one feels inclined to agree with him. It is no trivial disagreement, it is about the fact that this one person--let's just call him Abraham for the sake of simplicity--that this Abraham claims the Russians had already taken Pry and that they were on their way to Mieleworno. In his factory, let's assume it is the brickworks, someone said so: Kowalski, 
however, swears up, down and sideways that they aren't even as far as Pry yet. But Abraham sees no reason in the world to believe Kowalski rather than his co-worker.

"Who works in the freight yard?" Kowalski asks angrily. "You or me? Who hears everything firsthand? You or me?"

That is no valid proof for Abraham, particularly since his version sounds much nicer that Kowalski's, anyone can make a mistake, he says. Even the logical argument, that everything this mysterious colleague at the brickworks claims to know must in some way have originated with Jacob finds no favor with him.

"Or is there perhaps a second radio?"

"How should I know?" says Abraham.

Kowalski needn't realy care, let Abraham think what he likes, let him fall for ludicrous rumors like a trusting child, but somehow he feels he shares in the responsibility for the truth. Because in a way the radio is his radio too, ancient friendship with Jacob which to this day has not been broken, he almost had it transported to his own apartment at the time of the power failure, what a close call that was! So he explains with a patient tongue what a long way each news item has to travel from Jacob's mouth to the factory, via how many people, to what dangers it is exposed on its way, dangers of mutilation and embellishment. How everyone adds something to it, turning good news into better, and how this news finally appears in such a get-up that its own father is no longer able to recognize it. "In any case, the Russians are on their way to Mieleworno," says Abraham stubbornly. "Maybe you heard wrong, or he heard wrong. You'd better ask him again tomorrow." 
Kowalski doesn't ask Jacob tomorrow, the pretexts for a cozy chat with Jacob are rare enough, Kowalski goes to see Jacob immediately.

He finds him in the worst state imaginable, weary, apathetic, reticent, half an hour ago they came to take Elisa Kirschbaum away.

"Am I bothering you?" asks Kowalski, conjuring up a smile that after one searching glance at Jacob's face seems to him to be out of place.

"It's you," says Jacob. He closes the door behind Kowalski and lies down, fully clothed, on the bed on which he had apparently already been lying before the knock. He crosses his arms behind his head and stares at the ceiling, Kowalski wonders what is the matter with him all of a sudden, a while ago when they were coming home from the freight yard he seemed quite chipper, if one can speak of anyone's having been chipper around here lately.

"Did something happen?" asks Kowalski.

Did it or didn't it, Jacob feels a new kind of weakness, frighteningly sudden, when he came down from the attic a little while ago, after having taken up Lena, he had to hold on to the railing. He tried to explain this new condition to himself by the endless hunger, but that could only account for the shaking in his knees, hardly for the origin of the other kind of weakness, which was just as painful, this hopelessness. He puzzles over it, staring at the ceiling, and he tries to talk himself out of it, to make it smaller than it really is, so fat and weighty. The incident with Elisa Kirschbaum was surely only a small ingredient, there is no question that it took a lot out of Jacob, but it would be exaggerated to say that it was that incident which took all 
Jacob's hope away from one minute to the next. Of greater significance was Rosa's visit, having to listen to Lena's defending him with lies, with his own weapons, although one shouldn't blame just this visit either for Jacob's faltering strength. It adds up, a little bit here and a little bit there, most of all simply looking at the situation all around. More and more often someone takes you aside and says to you: Jacob, Jacob, I don't believe in a happy ending anymore, and when you have just finished consoling him as best you can with the most recent broadcast, there are always other ones standing there ready to tell you the same thing. The Russians are pressing in on Pry, according to the radio, God only knows whom they are really pressing in on, or who is pressing in on them. According to the radio, one ought to be able to see the first barrage in the distance, but day after day one sees the same sight, this horrible despair. Pretty soon you will have to consider withdrawal battles, because you got carried away in your advances to a point which unfortunately does not hold up to reality. And Kowalski is standing there idly, waiting in vain for a welcoming glance.

"Should I maybe go again?" he asks, after an appropriate length of time and sits down.

Jacob stands up, his ears are ringing with suspicious sounds, combined with dizziness and nausea, all he needs now is to get seriously i11. He hears Kowalski saying from quite a distance: "What's the matter with you?"

He quickly sits down at the table, fortunately it gets better, he thinks of Lena and what is to become of her and that one had better stay 
healthy. And when he finally looks at Kowalski, a little sign pops into his head, a little white sign with green letters: "Temporarily closed because of illness." He inherited it from Leib Pachman when he bought the cafe from him, it was part of the inventory along with a lot of other stuff. Only once did he use it in all the twenty years that went by with pancakes, ice cream and comparatively small worries, just once did the little sign hang in the door. And it wasn't even a real sickness, Jacob was built like a horse; trying to repair the jammed venetian blind, he had fallen off the ladder and had broken a leg, even the best of health wouldn't have been much help. That was long before Josefa Litwin's time, she would have come in handy here, a shriveled-up old witch in back of the apartment looked after him. For pay, of course, because there was no one else. She looked after him in a sense, she pushed the table with the food over to him so that he could help himself, emptied the ashtray from time to time and aired out the room, straightened out the bed in the morning and otherwise she said: "And if you need anything else, Reb Heym, call me, I'll leave my window open." Jacob tried that a few times, but either she closed her window anyway or she was deaf as a mule. And every two or three evenings Kowalski came by with a little bottle, and felt sorry for him having to lie there with one leg in a cast, unable to move. Sat there until the bottle was empty, neither one of them was a master of conversation, Jacob thanked God that the fracture healed without any complications. A few days more and he would have died of boredom. And a short time after he threw the innocent little sign into the furnace, watched with bitter glee as it entirely disappeared in the flames, and that warning had such lasting effect, that to this day he has been spared any confinement to his bed. 
"Wouldn't it be better if I left after all?" Kowalski interrupts his thoughts, having reached the end of his patience.

$$
\text { "Stay," says Jacob. }
$$

Kowalski looks at him questioningly, he has the feeling that Jacob means to tell him something, and nothing very good, judging from the halting introduction of these past minutes. And here he had planned a completely innocent visit, for on the way he had made up his mind not even to ask about Pry, since any error was out of the question, this Abraham must have fallen into the clutches of some loudmouth. He simply wanted to drop by and say hello and talk a little bit about the past and the future, who else is there but that one and only old friend, if he won't come to see you, then you'll go to see him.

"What do you think, Kowalski, how much can a human being take?" Jacob finally asks.

So he wants to philosophize Kowalski can't help thinking, he waits for an explanation to the question, for clarification in some direction or other, but Jacob seems to have asked it quite generally. He says: "We11, what do you think?"

"If you ask me," says Kowalski, "a lot. One stupid hell of a lot."

"But there is a limit." "Sure. . ."

"I am sorry, says Jacob, "I have reached my limit. Maybe someone else would have gone on, I can't."

"What can't you any longer?"

"I just can't." 
Kowalski gives him time, he doesn't know that Jacob is preparing his unconditional surrender, the worst of all confessions. All he sees is his bony face supported by his hands, perhaps a little paler than usual, a bit wearier maybe, but still the face of the same old Jacob whom one knows better than anyone. He does worry, because such fits of gloom are entirely unusual with Jacob, gruff and quarrelsome, that he is from time to time, but there is a difference, not whiny, it's the others who whine, Jacob was something of a source of comfort. Many a time, whether consciously or unconsciously, one would come to him, in order to get over one's own problems. Even before the days of the radio, and actually before ghetto times already. Whenever a particularly shitty day was over, whenever ne had stood behind the shopwindow from dawn until dusk looking out in vain for customers, or some huge bill had suddeniy arrived and it would not occur to you out of which pocket to pay it, where would one go in the evening? To his cafe, but not because his whisky tasted especially good. It was the same as any place and illegal at that, poured without a license. One went there because after such a visit the world looked a tiny bit rosier, because his way of saying: "Chin up," or: "It'll work out" was that much more convincing than anyone else's. Maybe too because he was the only one in one's meager circle of friends who took the trouble at all to say something like that. Kowalski gives him time.

Then Jacob starts talking, apparently to Kowalski, since there is no one else in the room, but judging by the words to a larger auditorium, talking to the air, as it were, there is melancholy in his soft 
voice and this new kind of resignation, the last of a prodigious number of broadcasts to everyone. That, if their feeble strength will allow it, they shouldn't be mad at him, but that he has no radio at all and has never had one. He doesn't know where the Russians are either, perhaps they'll come tomorrow, perhaps they'll never come, they are in Pry or in Tobolin or in kiew or in Poltawa or much futher still, perhaps they've even been vanquished by now, he doesn't even know that much. The only thing he can say for sure is that they were fighting in Bezanika at such and such a time, whence that certainty is a story all its own, which is of no interest to anyone today, but in any case that is the truth. And that he can well imagine how upsetting this confession must sound to their ears, therefore once again his plea for forgiveness, he wanted the best, but his plans came to naught.

Then there is a long silence in the room, a king has abdicated, as it were, Jacob tries in vain to discover some movement in Kowalski's face, but he looks right through him and sits like a pillar of salt. Of course Jacob is tormented by pangs of conscience as soon as the last word has died away, not because of the announcement itself, since it was long due and could not be postponed. But rather about whether one could have delivered it more gently, possibly shrouded it in a retreat of the Russians, in order not to pass the whole load so suddenly onto other shoulders, which are no broader than one's own. Whether Kowalski was necessarily the right man before whom to bring everything to an end, Kowalski of all people. If he had heard it from a stranger, from someone not quite so close to Jacob, he would certainly have believed it a mistake or an ugly rumor and he would have said to you after a night 
full of doubts: "Do you know what those idiots are going around telling each other? That you don't have a radio!" "That's true," would have been the answer, and it would have shocked him too, but perhaps not so much, because he would at least have considered that possibility the night before. And it might even have been possible to arrange things just in that way, Kowalski's bad luck to have come that evening.

"You aren't saying anything?"

"What should I say."

From impenetrable depths Kowalski conjures up a smile, without this smile he wouldn't be Kowalski, looks at Jacob again, his eyes are smiling less than his mouth, but are nevertheless giving no hint of an end to all hope, there is cunning in them, as though they were looking behind the surface, even now.

"What should I say, Jacob? I do understand you, I understand you very well. You know I am pretty much the exact opposity of a hussar, you've known me long enough. If I had had a radio here, no one would probably have heard a word from me. Or more likely still: I would have simply burned it out of fear, I make no attempt to deny that. To supply an entire ghetto with news! I would never have gone that $f a r$, you never know who might be listening! If ever in my life I have understood anyone, I understand you now."

How could Jacob have expected such flight of fancy, clever old Kowalski outdid himself, applying his calculations where there is nothing to calculate. How are you going to convince him that, right now at any rate, you are telling the truth, all you can do is to invite him to rummage around in all the corners, from this room down to the 
basement. But to insist with the palms of your hands turned outward: "When did I ever lie to you?", that you cannot do any more. And if in fact you challenge him to a search: all the radios you find in my place, Kowalski, are yours, he will wink at you knowingly and reply something like: "Let's stop kidding around, Jacob, haven't we known each other for forty years now?" He will intimate that there is no point in playing hide-and-seek games, the impossible cannot be proved. Jacob says, startled: "You don't believe me?"

"Believe, believe, what does that mean?" says Kowalski softly, with more distance than expected, in a tone of voice not unlike Jacob's just now in his little speech to everyone. That's all he says for now, his fingers drum a solemn rhythm on the table and his head leans way back, absorbed in secret thoughts.

Jacob considers further justifications, it matters to him that his verdict be bearable, and therefore the reasons for his venture must be known as well as the reasons for its sudden halt. But these aren't quite clear to him just yet, and therefore, and also because all this doesn't just concern him but Kowalski too, he keeps quiet and saves his plea for mitigating circumstances to a later date.

Then follows the sobering thought that this doesn't concern him at all, not a soul in the ghetto is less significant than he, without his radio. His listeners alone are of importance, Kowalski as well as many others. And they don't give a damn about justifications, no matter how plausible they may sound, they have other worries, not exactly small ones either, they want to know, for instance, what happens after Pry. 
Kowalski ends his drumming and brooding, he gets up, lays a befriending hand on Jacob's shoulder. He says: "Don't worry, old pal, you are safe with respect to me. I won't ask you any more."

He walks to the door, rekindling his smile before opening it, turns around one more time and actually winks with both eyes. "And I'm not mad at you."

And leaves.

The next morning, after the most sleepless night in a long time, Jacob is on his way to work. Before he stepped out onto the street he quickly tried Kirschbaum's door handle, for whatever reasons, but the door was locked. Horowitz, the neighbor, caught him at the communicative keyhole and asked: "Are you looking for anything in particular?" Of course Jacob wasn't looking for anything in particular, just looking, human curiosity, he quickly explained himself to Horowitz and left. Then there was the multicolored spot in front of the house, on the road where the little German truck had stood yesterday. A few drops of oil had dripped from it and were now glistening colorfully in thin threads on the disappearing remains of a reservoir that Siegfried and Rafael had created there together, first through their pant legs, then, when their sources had dwindled, with the help of a water bucket. Right after Elisa Kirschbaum's departure they had got to work, for a similar opportunity doesn't present itself every day, in traffic of this nature. Jacob was standing by the window watching them, along with Lena who was shocked at their shamelessness. 
But let's get back to our itinerary, from far away Jacob sees a larger crowd, at a street corner, right in front of the house where Kowalski lives. Jacob's first thought: he suspects Kowalski right in that throng, unable to keep his mouth shut, as is his nature. Either his nocturnal musings have brought him to the conclusion that he had been told the truth after all, or, as is more likely with Kowalski, he still doesn't believe it, but pretends to outwardly, for real friendship means sticking together. Stepped out of the house and in a one two three scared the Jews to death with his message of doom, because he must be first, come what may, in hell or in paradise, Kowalski up front forever. Cutting off all avenues of retreat that way, which, after careful consideration, one had decided not to make use of, but what business is that of Kowalski's.

Jacob is tempted to turn around, he relates, and to take a little detour, it'll be hard enough as it is, they'll torment him plenty at the freight yard yet. Let Kowalski suffer through this one alone, it's his business, it's a convenient opportunity to stay out of things. Then Jacob notices, still at some distance from the group, that people are hardly talking, when they should be stirred up after the presumed news, most of them are standing silently and stunned, as is becoming evident, a few are looking up. At an open window, at first glance there is nothing unusual about it, just empty and open. Jacob isn't sure whether it is Kowalski's window or the one next to it. And then he does see something unusual, a short piece of rope at the window bar, it's about a finger's length and therefore so late to be noticed.

Jacob rushes through the crowd and into the house, he attempts two steps at a time, but he can only do the first two that way, fortunately 
Kowalski lives on the second floor. The door is open just like the window, there is a draught, Kowalski's three roommates, one of whom we have arbitrarily named Abraham, are no longer at home. Only Kowalski is home and two complete strangers in the room, the first two passersby to have seen him hanging. They cut him off and layed him on the bed, now they are standing around helplessly, not knowing what else to do. One of them asks Jacob: "Did you know him?"

"What?" asks Jacob, standing in front of the bed.

"Did you know him?"

"Yes," says Jacob.

When, after a while, he turns around, he is alone, they have closed the door. Jacob goes to the window and looks down on the street, no more crowd, only some passersby. He wants to close the window, but it sticks, he has to untie the double-knotted rope from the frame first. Then he pulls the curtains, the dimmed light makes Kowalski's face more bearable. He pulls up a chair, he doesn't want to sit down on the bed, he takes a seat for an indefinite time. I say indefinite, because later on he is unable to give any particulars about its length.

The sight of dead people is anything but unfamiliar to Jacob, it isn't unusual to have to step over someone lying on the sidewalk dead of starvation and not yet spotted by the sanitation squad. But Kowalski isn't just someone, good God, no, Kowalski is Kowalski. A confession led to his death, one that he pretended not to believe at that, why did you, madman, not stay last night? We would have talked over everything calmly and given ourselves that bit of courage to go on living. What haven't we given one another already, real or unreal, if it succeeds no 
one will ask how, why did you have to play the poker player on your last evening? We could have helped each other, but only you knew what was going on inside of us, you concealed yourself to your friend Jacob Heym, you showed me a false front, and yet we could have lived on, Kowalski, you and I.

Barber by profession, had stashed away a bit of money, as we know, with the intention of making a change later on, probably would have stayed a barber, however; was endowed with some questionable qualities here and there, was distrustful, eccentric, clumsy, garrulous, overly clever, and if it's all totaled up in the Hereafter, then suddenly loveable, once saved Jacob from a terrible predicament, from a German toilet, subscribed to the Volkische Landbote for commercial reasons, was capable at times of eating seven large potato pancakes at one sitting, but couldn't digest ice cream, preferred borrowing to repaying, wanted to appear calculating, but wasn't at all, with one exception.

As is to be expected, self-reproaches are racing through Jacob's mind of Kowalski's being on his conscience, of him and his small-minded weariness being responsible for Kowalski's resorting to the rope, whatever one starts one must follow through with, one must assess one's strength beforehand. I interrupted Jacob, I said to him at this point: "You are talking nonsense. You did not overestimate your strength, because you couldn't have known that it would take this long." And I said to him: "You are not to blame for Kowalski's death, rather he had you to thank for having lived to that day." "Yes, yes," Jacob answered me, "but what good is all that?" 
Finally Jacob gets up. He pulls the curtain back to the side, leaves the door wide open when he leaves, so that one of the neighbors would notice the incident upon his return from work and take the necesary measures. For the freight yard it is now much too late, one can't very well tell the guard at the gate that one was detained en route, lunch is necessarily cancelled. Jacob goes home with one hope: that Kowalski may have kept his reasons to himself, that this one time he may have been discreet. For Jacob has found his radio again.

Jacob can find it a million times, report, invent battles and circulate rumors, one thing he cannot prevent, this story is inevitably approaching its vile end. That is, it has two endings, in reality of course ony one, the one experienced by Jacob and by all of us, but for me it has yet another. In all modesty, I know an ending that would turn you green with envy, not exactly a happy one, a bit at Jacob's expense, imcomparably more successful, however, than the real ending; I have worked on it over many years. I said to myself, what a crying shame that such a beautiful story should end so pitifully, invent an ending for it with which one might be halfway satisfied, a sensible one, a decent ending makes up for many a weak spot. Besides, they have deserved a better ending (not just Jacob), that will be your justification, in case you need one, I said to myself, and I tried hard, successfully, I think. But then I had strong compunctions regarding its truthfulness, it just sounded too beautiful by comparison, I asked myself if it is right to pin a gorgeous peacock's tail onto some sadlooking animal--out of love. Whether one doesn't ruin it by so doing, then I thought that the comparison was weak, but I never did 
resolve the matter. And here I am now with the two endings, not knowing which one to tell, mine or the ugly one. Until it occurs to me to use them both, not out of indecisive-ness, but I simply feel that this way we will both be duly considered. The story in which I have no say on the one hand, and on the other, me and this effort of mine, which I would not want to have made in vain.

Well then, first an ending that never happened.

Kowalski may celebrate his resurrection, window frame and rope are not even remotely considered by him, for Jacob foregoes his confession. On that particular evening they chatted about trivia, although Jacob's heart is not in it, but Kowalski needn't notice that. Not until later, when he is alone again, does Jacob realize that it is beyond his dwindling powers to continue with his radio lies, and for an indefinite period of time at that. Nevertheless the true state of affairs must not get to the outside world, Jacob envisions what consequences that would have, he could, for example, fear that then the rash of suicides, which, luckily, had been halted for some time, would start anew and grow to immense proportions.

The following nights, which have now been freed up by the fact that all self-reproaches over Kowalski's death have been eliminated, these very nights Jacob spends searching for a last credible lie. It must explain why the radio had stopped playing, he must rid himself of this worst of all plagues, but that lie will not occur to him, it proved harder to think up than any of the others.

I imagine for a moment that Jacob might have hit on the idea of simply claiming that the radio was stolen. Lots of things are stolen in 
the ghetto, why not a radio, one has missed objects of smaller value and use, I imagine a whole ghetto searching for the unscrupulous thief, one now looks at another questioningly, visits have turned into pretexts for inspection. In the evening everyone listens at his neighbor's door, maybe he has just tuned into radio London, maybe he is the bad guy, hasn't he always had something peculiar in his look, something your inner voice warned you about? Only one thing is impossible to understand: to what advantage is this crime for the thief, certainly none, he won't find out anything different now than he would have heard from Jacob or from one of his clients anyhow, only the others are groping in the dark, what's the point of it? How else can his motives be explained except as those of a wretched individual? I further imagine the search for the thief taking on alarming dimensions, that a kind of illegal committee is formed to comb house by house after working hours. And let's suppose among the several thousand inhabitants there is another person like Felix Frankfurter, just one, who is also keeping a radio hidden, and, unlike Frankfurter, has not destroyed it.

I am well aware of the fact that this one person would be very problematic for the whole story, for either he, like Frankfurter, was too scared to ever listen to it, or he did listen and must therefore know that Jacob's daily reports were nothing but lies, with the exception of the battle at Bezanika. And just kept quiet about it the whole time. Improbable as each of these two possibilities may be, let us carry any one of them just three sentences further, since that man is really just a figment of the imagination, a playful whim. The radio is found in his place during the search, he is clubbed to death--some whim 
(one might interject)--or he is not clubbed, that is irrelevant. The radio is brought to Jacob, its rightful owner, just the thought of the expression on his face is worth this whole idea. Then things retake their normal course. Jacob listens and reports, for days the talk about this outrageous incident continues, how can one single person act so vilely, for no reason in the world!

But enough of that, Jacob does not hit upon the idea of the theft, neither in the real ending, which surprises me, nor in mine. In my ending he torments himself in vain, he just can't get rid of the radio, so he decides to get rid of the Jews. He receives no more visitors, simply doesn't open the door, at the freight yard he secludes himself, he spoons up his lunch near the German brick house, where no one can ask him anything. And right after quitting time he disappears like a ghost, he puts up with detours, in order to avoid any questioning. Now and then he is intercepted anyway, despite all precautions, then he is asked what is the matter with him all of a sudden, why isn't he telling anying any more.

"There is nothing new," he tells them. "If there is something new, I'll be sure to tell you."

Or, more effective yet, he says: "It has become too dangerous for me, I don't want to risk anything any more so close before the end. Just do me the one favor and don't ask me any more."

He doesn't exactly make himself popular that way, only a few have any understanding for his position, yesterday's bigwig is rapidly sinking in their estimation. Coward they call him and shithead, also because he stubbornly refuses to let someone else have the radio, one 
who is not quite so lily-livered. Eyes stare at him in frightening ways, they whisper behind his back and lucky are those who don't hear it, but Jacob does not revoke his decision. Let them take him for the bad guy, he would do the same in their place, let them show him on every occasion what contempt tastes like, all that is better than telling them the truth.

He is, however, not totally forsaken by his friends, I imagine that Kowalski and Mischa will stick by him. Mischa continues hauling crates with him, Kowalski says now and then (though less of ten than before): "Well, what's up, old pal? Can't you at least give me a little hint? No one need notice."

Jacob declines each time, risking the loss of his oldest friend. He doesn't lose him, Kowalski proves to be a tenacious friend.

One day Mischa says: "Jacob, it hurts me, but they are talking about taking away your radio."

"Taking it away?"

"Yes," says Mischa seriously. "By force."

Jacob looks over at the others, one or the other is ready for coercion, Jacob prefers not to know who they are.

"Can't you keep them from doing that?" he asks.

"How?" asks Mischa. "I would gladly do it. But can you tell me how?"

"Tell them I've hidden it so well that they can't possibly find it."

"I'll do that," says Mischa.

At home Jacob strictly forbids Lena to be in his room during his absence and just to be sure he no longer leaves the key in the hole of 
the wall behind the doorframe, not for Lena nor for anyone. She is to stay up in her attic as much as possible and to keep quiet, he lets her take the book about Africa upstairs to fight boredom, she can learn to read from it, she'll get more out of that than out of hanging around doing nothing.

The next few days develop into a strenuous test for Jacob's frazzled nerves; he must wait quietly, his hands in his lap, wait for liberators or for burglars, uncertain with both whether they will come or stay away. Mischa says he has no idea whether the opposite camp has changed its mind, for since his allegiance to Jacob has been noticed, despite all that has happened, since he has offered his services as an intermediary, he has been excluded from all deliberations. Even worse, a morsel of the general contempt falls upon him too, the same goes for Kowalski.

I haven't thought about how I am going to behave in this matter, on which side I am, whether Jacob's friend or foe. But knowing myself, and when I stop to consider how much the constant reports have meant to me, I am his enemy, one of the worst even. Let us assume I plead emphatically for not letting ourselves be confused by all the talk and for taking his radio away, not tomorrow, but this very day. Many share my view, but some other Jews ask to be heard too, those for example who, from the very start, had considered the radio a danger. They are basically happy about Jacob's change of mind, they say: "Don't make such a fuss about it. If the Russians come at all, they'll come no matter what."

And others again say: "Let's wait a while, maybe Heym will come to his senses. Let's give him a little time." 
At any rate, the burglary doesn't take place, not in my ending. These horrible days turn out to be a trial for Jacob in another way as well, at some point he will have to realize that he has remained loyal to what has already become an old habit and that again he has overestimated his own strength. He was convinced that the wave of hostility, which he had had to anticipate, would not bother him much, that he would be able to survive it, he talked himself into being courageous by telling himself that he had practice in these matters, all those years in the cafe had pretty much been a battle of one against a11. That was a careless fallacy. The time since Bezanika had simply not been considered, during which Jacob had been showered with good will, affection, and respect, and with signs of utter dependence, to which it is ridiculously easy to become accustomed. And now the exact opposite; after ten days at the most this wave of hostility is threatening to crash over his head, the cold shoulders have become unbearable.

Lena notices a change in Jacob and doesn't know what to make of it, she follows his instructions obediently, stays in the attic and so hears of nothing. She only sees that whenever Jacob is with her, he becomes absorbed in joyless thoughts, hardly speaking a word any more, not even showing due amazement when she reads him a whole sentence from the Africa book, without any help. When she sits down on his lap, she sits there just like on a chair, up until recently he was gladly offerher his knee, now he doesn't seem to notice her. When she asks him for a story, he says he doesn't know any and puts her off for a later time when he can think of one again. Lena asks: "Are you annoyed about something?" 
"Annoyed? Why annoyed?"

"Because you're so strange."

"I am strange?" says Jacob, unable to muster up the strength to skip the pointless edge in his voice. "Mind your own business and leave me alone."

Lena stays all alone with very little to look after, only Jacob, to whom something must have happened that she is unable to understand.

On an important evening in my ending, shortly after the first of the month, because ration cards are always given out then, Jacob knocks at Mischa's door. After quite some time the door is cautiously opened, Mischa says, amazed: "Jacob?"

Jacob steps into the room, the first thing he says: "If you really want to hide her, you shouldn't leave two cups on the table, you idiot."

"That's true," says Mischa.

He goes to the clothes closet and lets Rosa out. Rosa and Jacob stand facing each other silently for such a long time that Mischa begins to feel embarrassed.

"Do you know each other?" he asks.

"We met very briefly once," says Jacob.

"Have a seat," says Rosa politely and quickly, before Mischa asks about that one time. Jacob sits down and searches for a beginning, because he hasn't just dropped by, his concern is a weighty one.

"The reason I'm here," he says. "I want to ask you for a favor, and if you decline, I can very well understand it. I just couldn't think of who else I could go to with this." 
"Out with it," says Mischa.

"The thing is, that I have been feeling wretchedly bad in the past few days. Physically I mean. I am no longer a young man, my heart is acting up and my back, and headaches all the time, pretty suddenly, it's a little much all at once.

Mischa can't understand yet what kind of a favor is involved, he says: "That's bad."

"Well, not that bad, it'll pass. But until it does, Mischa, I wanted to ask you if in the meantime you couldn't take Lena in with you."

In the general consternation there is a pause, during which Jacob looks at no one, he is probably asking too much of a young man. Two illegal females in his apartment, but he did say right away that he wouldn't be mad about a rejection of $h$ is request.

"Well, you know," says Mischa with all too clear intentions.

"Of course you can bring Lena to us," says Rosa, looking reproachfully at Mischa.

"I would never have come to you with this, if you had been alone," says Jacob to the unhappy Mischa. "But since Miss Frankfurter is here the whole day anyway, and Lena is always alone too. . ."

"I am already looking forward to her," says Rosa.

"And what do you say?"

"He is looking forward to it too," says Rosa.

Mischa waits a while until he has adjusted his facial expression, everyone knows that he is not exactly delighted, he says: "Go ahead and bring her over." 
It is with relief that Jacob puts the rationcard on the table, untouched except for one coupon, Mischa need no longer fear that he is asking for free board as well, complete room and board, as it were.

"When can I bring her over?"

"When had you thought?"

"Tomorrow evening?" Jacob asks.

Mischa accompanies him, even though Jacob insists that it is not necessary, just the few steps to the street. When Jacob shakes his hand good bye, Mischa holds it a moment longer than necessary, and Jacob discovers an important question in his blue eyes. Mischa is absolutely right, Jacob thinks, one act of friendship deserves another, especially when it is requested with such modesty.

"You want to hear how things are going?" he asks.

"If you don't mind," says Mischa.

Jacob lets him in on the secret that Pry has meanwhile been captured, that the Germans, however, have dug in half way toward Mieloworno, which will result in a protracted fighting, it seems; however, the first breakthroughs have taken place, which again sounds hopeful. And he asks Mischa to keep the news to himself, otherwise there would only be endless questioning at the freight yard as to why one of them is informed and not all the others. Mischa promises, surely in the hope of further news now and then, at least that's how I try to explain his tactics to myself.

One evening later Lena moves. Jacob gave her the same reason as he had to Mischa, a separation for just a few days, and Lena accepts it calmly. After all, she likes Mischa, something of a secret love, and 
he presumably likes her too, only this Rosa still bothers her, because of that visit and the reproaches, there could be problems with her. But Jacob assures her even on the way over that Rosa is easy to get along with, helpful and friendly, that just last night she told him that she was looking forward to Lena. It seemed best not to mention that silly visit the other day at all.

"You are a big girl, so don't embarrass me."

After Jacob has dropped off Lena he goes straight home, to lie down, he says. For a long time he sits in the dark, wondering whether the decision, for the sake of which Lena had to leave, is defensible. He doesn't want to have to blame himself later on, if there still is any occasion to, too often lately has he been making wrong decisions. To let the Russians advance almost within sight was a mistake, the stopping of the news reports was a mistake, the radio itself was the first and biggest, it seems to him, too many mistakes for one single guy. There is still the possibility of undoing some things, of returning to the old routine. In three or four days he could be feeling better, sickness of this kind can be cured at will, then he could bring Lena back, and at the freight yard he would play the repentent sinner and provide the curious with news, good ones and bad ones, but what would that lead to, Jacob asks himself.

After about two hours, I think, Jacob has arrived at a decision. He hangs the blanket in front of the window, turns on the light, then takes a knife, takes off his jacket and removes the yellow stars from front and back. He does it very carefully, pulling out the white threads as well, so that later on they won't reveal the notorious spot. 
His eyes search the room for objects that might possibly be of use in this venture, there is, of course, the pliers, he puts it in his pocket. Otherwise nothing occurs to him, he turns off the light again and looks out the window one last time. Onto the dark deserted street, it's long past eight and curfew time, probably midnight already, he can likely make out the searchlight in the distance, as it is passing dutifully and aimlessly over the rooftops.

Because there are no limits to my fancy, I am letting it be a cool and starry night, that doesn't just sound pleasant, it comes in handy for my ending as well, you will see. So Jacob walks along the street without stars and long past eight, that is, he tiptoes close to the walls of the houses, trying to look like a shadow, for it is not his intention to lose his life. One street, then another, and yet another, they all have one thing in common: they lead directly to the border.

Then the border, I chose the most favorable spot imaginable for Jacob, the old vegetable market, a small paved square with barbed wire strung acorss, the real escape attempts have almost always succeeded or failed right at this spot. At the right edge of the square is the watchtower, this one without a searchlight, the guard up there isn't stirring as Jacob watches him from a house entrance at the far left. The distance may come to 150 meters, along the wire fence circling the entire ghetto there is not one other spot so far from a tower, for reasons of economy or easy visibility.

The tower is quiet as a statue, Jacob is beginning to hope that the guard has fallen asleep. Jacob looks at the sky and waits cautiously for one of the rare clouds to move in front of the uncooperative moon. It finally does him that favor, Jacob takes the pliers out 
of his pocket and dashes off.

At this highly dramatic moment in my ending, let us insert a short pause, in which I take the opportunity to confess that I cannot cite a reason for Jacob's sudden flight. Or rather, I won't make it that easy for myself by simply claiming: "In my ending he just wants to run away, that's all!", I am quite capable of giving several reasons, all of which I consider likely. I just don't know which one in particular to chose. For example, Jacob has given up all hope that the ghetto will ever be liberated for as long as there are still Jews in it, and therefore wants to save his own hide. Or, he is fleeing from his own people, from their snares and hostilities, from their curiosity too, an attempt to find safety from the radio and its consequences. Or a third reason, the most honorable one for Jacob, he has the daring intention to return to the ghetto the following night, he just wants out, in order to get useful information, which he might then put into the mouth of his radio.

Those are about the most important reasons, none of them to be scoffed at, you will have to admit, but I can't summon up the courage to commit Jacob to any one of them. So I am offering them for selection, let each person choose the one that from his own experience he finds the most likely, maybe some will even be able to think of more plausible ones. I would just like to suggest that most matters of importance that have ever happened, happened for more than just one reason.

Under the protection of the cloud Jacob reaches the barbed wire unnoticed. He lies down flat upon the ground, the simple plan is to crawl through underneath the barrier. Which of course is easier planned than done, the lowest of several wires is only ten centimeters above the 
ground, but that was to be expected, hence the pliers, just in case. And now the pliers is brought into the act, working nimbly away at the thin wire, which can't hold out forever and which snaps faster than expected. But the noise, for it is tautly strung, this horrible hum, Jacob wouldn't be surprised if it turned out to be able to jolt a whole city out of its sleep. He holds his breath and listens fearfully, but everything remains quiet, it just gradually turns lighter, for no cloud lasts forever. The next wire is ten centimeters higher, that is twenty above the ground. Jacob worries that to crawl underneath it would entail a certain amount of danger for body and clothing, admittedly he is much thinner than he used to be, but he is a grown man. On the other hand, he does not want to risk breaking the silence once again by making the second wire ring, it won't be one bit quieter than the first, and a third alternative is not to be found.

Jacob is still lying there undecided, carefully plucking away at the wire to see whether it might be loosened to soften the noise when the pliers sever it, when suddenly he is relieved of the decision by a higher authority. I have already mentioned that this ending of mine is a bit at Jacob's expense: a noisy blast from a machine gun disturbs the tranquility of the night, our guard wasn't sleeping so soundly after all. And there is nothing more to worry about, Jacob is dead and all his troubles are over.

But that isn't all, what kind of an ending would that be, I can also imagine that the ghetto isn't going to settle down for a long time. I picture the revenge for Jacob, for I determine this to be the cool and starry night in which the Russians arrive. Let the Red Army 
have succeeded in encircling the town in record time, the sky lights up from heavy gunfire, right after the salvo that was aimed at Jacob a deafening thunder starts up, as if it had accidentally been triggered by the poor guard in the watchtower. The first phantomlike tanks, explosions at the police station, the watchtowers burn, tenacious Germans defending themselves to the last shot, or fleeing Germans unable to find a hole in which to hide, good God, what a night that would have been! And Jews weeping behind windows, everything has come so suddenly for them that they can only stand there incredulously, holding hands and wanting to rejoice for their lives, yet unable to do so, there'll be plenty of opportunity for that later. I imagine that by dawn the last battles have been fought, the ghetto is no longer a ghetto, just the shabbiest part of town, anyone can go wherever he pleases.

Mischa thinking that Jacob must be feeling better now, taking Lena back to him and not finding him home, then the taste of the bread that is handed out in abundance, all those things and more are not important enough to me to take up room in my ending. Only one thing is important.

Some of the Jews leave the ghetto by way of the old vegetable market. They see a man without stars lying there, his pliers still clenched in his right hand, under the barbed wire that has a severed strand, obviously caught trying to escape. They turn him over on his back, who is this unfortunate person, they ask, and somebody is standing nearby who knows Jacob. Kowalski, most preferably, but it could also be a neighbor or me or someone from the freight yard, anyway, someone who knows him, but not Lena. This person stares at Jacob's face in horror, 
perhaps the first good news from Jacob had reached him on a day when he had been about to decide to save himself the trouble of living out his life, and now he mumbles soft words of disbelief. "What do you mean 'unbelievable'? The poor guy wanted to escape because he did not know that it would be over so soon. What is so unbelievalbe about that?" And that one fellow with the lump in his throat starts in on the hopeless attempt of trying to explain what will forever remain inexplicable to him.

"But that is Jacob Heym," he says. "Do you understand? That's Jacob Heym. Why would he want to escape? He must have gone crazy. He knew they were coming. He had a radio. . ."

Those are more or less his words as he walks off to freedom with the others, and this is more or less my ending.

But after the invented ending let's have the pale-cheeked and unpleasant one, the real and unimaginative one that makes you want to ask the absurd question: What's it all for?

Kowalski is irrevocably dead and for now Jacob lives, doesn't waste one thought on burdening strangers with Lena, does not strip his jacket of the prescribed stars, leaves the pliers in the drawer, if he owns any at $a 11$, and hence doesn't induce any guard at the old vegetable market to firing shots capable of setting off that powerful echo in the c00l starry night. He did miss work that day, we know why, his hanged friend is spooking around in his head, but he has to retreat before daybreak. To retreat, in order to make room for some urgent considerations, Jacob has seen with his own eyes what this business with his 
radio is leading to, maybe it doesn't take on such drastic forms with everyone, but it certainly does with some, and that is why nothing about the radio is going to change. The grief about Kowalski, who is suddenly missed more than he ever was in his lifetime, must sit patiently on a long waiting bench, and, instead, the little news factory which feeds its man so grudgingly, begins to work again, for there'll be questions again tomorrow, as every day, life drags on no matter what.

Then the next morning, Jacob walks past Kowalski's house with tight lips, staring straight ahead at some imaginary point at the end of the street. But, of course, everyone knows how hopeless it is to try to force yourself not to think of something, Jacob sees him lying there as vividly as if he were with him in the room, once again he unties the remainder of the rope from the window frame, pulls up the chair, because he doesn't feel like sitting on the bed, and, to top it off, he even hears the end or the beginning of a conversation.

"In that house over there."

"Number fourteen?"

"No, number sixteen. The corner house."

"Do they know who already?"

"Unknown. A certain Kaminski or something like that."

At quite a distance from the freight yard Jacob already realizes that something unusual must have happened, the Jews, all ready for work, are crowding around the entrance because the gate is closed. Why they are not being let in is a mystery to him at first, another mystery why the first person who discovers him is pointing at him, says something, and then the others turn their faces toward him. Fifty, sixty men 
men waiting for Jacob, I am one of them, we see the only person who can still place himself between us and the disaster, coming towards us hesitantly and puzzled. We make way for him, forming a narrow lane so he can walk to the gate without hindrance, read what is posted there and then tell us that it isn't all that bad. Next to me lawyer Schmidt is shuffling his feet nervously, I hear him whispering to himself: "Hurry up!" because Jacob is walking so exasperatingly slowly and looking into the men's eyes instead of straight ahead.

Right on time for work Jacob arrives at the locked gate of the freight yard and reads the posted announcement: that all of us are to assemble in the square in front of the police station at exactly three o'clock, five kilograms of baggage per person, apartments are to be left unlocked and in clean condition, whoever is found in his house after the prescribed time, the same goes for the bedridden and infirm, further information at 1 PM at the place mentioned above.

And now try to keep giving them consolation, don't ask where to get it, try to persuade them that it's all a bad joke, that it is really going to be a field trip with many lovely surprises, that's just what they are waiting for behind your back. No reason to worry, brothers, is what they want to hear, go ahead and ignore that scrap of paper, don't bother with it, whoever is curious can go ahead and come to the police station at one o'clock if he's got nothing better to do. There is no way anything could happen, because, you don't even know this yet, I completely forgot to tell you, the Russians are already waiting behind the next corner, watching that no harm will be done to any of you. 
To us it seems as if Jacob were memorizing those few lines, he's been standing in front of that poster for so long. Why is he standing there for so long, we ask ourselves in silence, suspecting the worst, what will his face look like when he shows it to us again, and what will he say, he's got to say something; I can see, too, that the first ones are quietly leaving the ranks. I know depressingly well that they are right, there is nothing more to expect here, nevertheless I keep hoping and do not move from the spot, just like most.

It's not worth it. After an eternity Jacob turns around, presents us with two vacant eyes, and at that moment even the dumbest one among us realizes that all happiness has been gambled away. Jacob has, he tells me, no time for personal shock at the course of events, the shock of the others pushes it away, they are looking at him like cheated creditors, as if the day had come in which to redeem the pledges he had so carelessly distributed. Again he stands there for a long time, not daring to look up, and they aren't making it any easier for him by, for example, disappearing, there is lots of time left for the five kilograms of luggage to be selected, all the rest of their lives, one might say. The narrow lane that had opened for Jacob on his way to the gate has now closed behind him, he stands in a narrow semi-circle, in Jacob's own words: like a jokester who has forgotten his punch line.

"Don't you have anything better to do than to stand around catching flies?" asks a guard behind the fence.

Only now do we notice him, he's been standing a few meters away from the gate, he alone knows for how long. In any case, he didn't hear much, although what is important has already been said. We finally 
move away, why provoke him unnecessarily, and disperse silently. The guard shakes his head, amused at these strange creatures, Jacob is almost grateful to him for his unintentional help.

Having arrived home, Jacob immediately goes up to the attic. He is expecting to find Lena still in bed but she isn't even in the room any more. And yet the weather isn't doing its best, there are just a few blue patches in the sky; Jacob has a hunch that his instructions weren't taken too seriously. Her bed is neatly made, the piece of bread gone from the plate on her dresser, right after he said good bye to her in the morning she must have gotten up and hurried off to some activity of which one never hears anything. Jacob decides to look for her later, to pack her things first, then his, and when that is done Lena will turn up. And he doesn't waste time worrying about whether the notice at the gate is meant only for those employed at the freight yard or for all ghetto residents. For he has no other choice but to take her along, to leave Lena behind would not mean to hope for an uncertain fate for her, that is easy enough to figure out.

The prescribed maximum amount of baggage proves to be quite generous, her total amount of useable stuff comes to hardly more than a handful. Jacob stuffs underwear, stockings and scarf into his pockets, as he is folding her winter dress, Lena appears. She is holding a last bit of bread in her fingers, Jacob's presence greatly surprises her. But she immediately notices his disapproving glance and interprets it correctly right away, he will be angry because she left the attic against his wishes.

"I was only at the pump. I was thirsty," she explains. 
"All right," says Jacob.

He finishes with the dress and hands it to her to hold, then he looks around, opens the dresser drawers once more, in case something has been forgotten.

"Am I going to live downstairs with you again?" asks Lena.

"Come on," he says.

They go to his room. On the stairs they meet their neighbor Horowitz who seems to be coming from the basement and is struggling with a large leather suitcase whose locks do not hold the lid shut.

"What is your opinion about it?" asks Horowitz.

"Take a guess," says Jacob.

Now he knows for sure that the order at the freight yard gate applies to everyone, the silly question of Horowitz's and the suitcase in his hand, there was probably a notice posted at every factory entrance during the night.

"Have you by any chance heard where they are taking us?" "No," says Jacob.

He hurries to his room with Lena, before he can be drawn into long disputes, all he would really like to know is what a single Horwitz has in mind with that gigantic suitcase, surely on his notice there wasn't anything about a couple of hundred kilograms per person.

When the door is closed behind them, Lena reveals that she can't stand Horowitz. She always tries to avoid him because he has an unimiited stock of admonitions for her, not to hang around, to say hello, not to look at him like that, to stop making so much noise, there is always something that occurs to him. Once he even grabbed her by the arm and 
shook her because she had slid down the banister and landed at his feet. Jacob says: "How about that."

After he has taken Lena's things out of his pockets and laid them on the table, he starts packing. That is, first there is the choice between suitcase or backpack, there is ample room in either. For reasons of practicality the backpack wins out, for on a trip of uncertain duration, on which one hand must always be free for Lena, a suitcase could become torture.

Lena stands there hoping for a good while that Jacob will explain his peculiar actions to her on his own, but he only says from time to time, give me that, hold this, and not a word to soothe her curiosity. So she has to ask: "Why are you packing all those things?"

"Well, what do you pack things for?"

"I don't know," she says, emphasizing it by shrugging her shoulders vigorously, the way we have seen her do before, shoulders up to her ears.

"Then think about it."

"To go on a trip?"

"That's it, smart girl."

"We are going on a trip?" Lena shouts, and it sounds a little like: "And you didn't tell me until now?"

"Yes, we are going on a trip," says Jacob.

"Where?"

"I am not sure."

"Far away or near?"

"I think pretty far away." 
"As far as America?"

"No."

"As China?"

"Not that far either."

"As far as Africa?"

Jacob knows from experience that she is capable of continuing such games for hours, so he says: "Yes, about as far as Africa."

She jumps round the room, hardly able to contain her joy, and Jacob puts on a cheerful expression, after all, the girl has never been on a trip. It gets expecially hard to bear when she suddenly gives him a kiss and asks him why he isn't happy too.

"Because I don't like to go on trips."

"You'll see how nice it is."

He finishes with the backpack, two spoons on top, is about to tie it up when Lena puts her hand on his arm and says: "You forgot the book."

"What book?"

"The one on Africa."

"Oh, yes. Where is it?"

"Under my pillow. I'll get it quickly."

Lena runs out, Jacob hears her joyful voice in the hallway and up the stairs. "We're going on a trip! We're going on a trip. . ." Just for the joy of it or maybe to annoy the sourfaced Horowitz a little under Jacob's protection. 
Then we travel.

In the train car it is cramped and sticky, the Jews are squatting or sitting on the floor beside their five kilograms, at least thirty of them, I think. Sleeping at night, should the trip last that long, will be a problem, for not everyone can lie down at the same time, it will have to be done in shifts. It is dark too, the few narrow peepholes right under the roof provide little light, and besides, they are almost always occupied. There are hardly any conversations to be heard, most look as if they had to think about horribly important and serious things, though amidst the rumbling of the rolling wheels one could converse without being overheard, despite the crowded condition, if one wanted to.

I am sitting on a checkered pillow case containing all my junk, I am bored, beside me an old woman is crying, quietly and considerately. Her tears have long since run dry, yet from time to time she sniffs so forcefully through her nose, as if entire streams were to be contained. And her husband, with whom she shares her suitcase, looks around each time apologetically, because he is probably embarrassed by it and wants it understood that this matter is beyond his control.

On my left, where I have no choice but to direct my attention, Jacob has conquered a peephole, but I can assure you that this proximity is purely coincidental. I didn't push to be next to him, I don't go as far as some fools who accuse him of some kind of share in the blame for this trip, but I can't deny that I feel an unfair anger against him, because all the structures I had built on the foundations provided by him have collapsed. I didn't push to be next to him, I don't care whom 
I ride next to, it just turned out that way. Through Jacob's legs I can see Lena, whom so far I had only known through hearsay, she is sitting on the backpack. Lena again makes him more appealing to me, I say to myself, who else would have burdened himself with a child, and I think that that weighs at least as heavily as my disenchantment.

I would like to make her acquaintance by winking or making faces, as one does, but she doesn't even take notice of me. She is gazing thoughtfully at the floor, no doubt she is busy with the kinds of thoughts that are foreign to everyone else right now, for at times she is smiling to herself. Or her lips form silent words, or she makes a face as though she weren't sure of things, it's fun to watch her. I find a round little pebble on the floor and shoot it at her arm. She emerges from her thoughts, looks up to see who could have done it, looks around everywhere, but not at me. Then she loks up at Jacob, who, beyond all suspicion, is standing in front of the peephole, motionless, his entire attention focused on the passing landscape. She tugs at the calf of his leg.

He looks down and asks: "What is it?"

"Do you remember the fairy tale?" asks Lena.

"Which one?"

"About the sick princess?"

"Yes."

"Is that true?"

It is easy to see from the look on is face that he finds it odd that she is thinking about that just now.

"Of course it is true," he says. 
"But Siegfried and Rafi didn't believe me."

"Maybe you told it badiy?"

"I told it just as you did. But they say that there is no such thing in the whole world."

"What thing?"

"That you can get healthy if you get a piece of cotton."

Jacob bends down and lifts her up to the little window. I stand up too, because the wheels make quite a lot of noise and I want to hear the rest.

"But it is true?" says Lena. "The princess wanted a piece of cotton as big as a pillow? And when she got it, she got better?"

I see Jacob's mouth broaden, he says: "Not quite. She wanted a cloud. The point is that she thought clouds are made of cotton, and that's the only reason she was happy with the cotton."

Lena stares out for a while, puzzled, as it seems to me, before she asks him: "But aren't clouds made of cotton?"

Between their heads I can see a piece of sky with a few clouds, and I have to admit that the similarity is indeed amazing, they look like wads of cotton.

"Then what are clouds made of?"

But Jacob promises her an answer later, probably in part because she is beginning to get heavy for him, he sets her back on the backpack and then watches the landscape pass by.

At this moment I decide that my moment has come. I sit down too, move closer to her and ask if she would like me to tell her about rivers and lakes and about the sea, about the perpetual cycle of the water, 
about the unbelievable matter of evaporation, how the water flows invisibly into the sky in little droplets, collecting there into clouds that later become as heavy and wet as soggy sponges until they again get rid of the drops in the form of rain. And I don't omit the vapor either, from locomotives, for example, and chimneys and all kinds of flames, she listens to me attentively but skeptically, I can see that this whole long story can't be exhausted in one lesson. I can also see Jacob looking at me in a friendly way, perhaps it is because of my instruction that a few days later he tells me a much crazier story, to me of all people. Because it is not written on my face that I will be one of the few survivors.

When all my knowledge about the origin and composition of clouds has been exhausted, I tell Lena to feel free to ask questions if she hasn't understood something. But she makes no use of this offer, she props her head on her hands and thinks the matter over once more calmly. After all, she has to get over a serious error, clouds are not made of cotton.

"You don't know what you are getting yourself into," Jacob whispers into my ear.

"Why?"

"Because you don't have any idea what kinds of questions this child can ask."

I look at her and say: "It can't be all that bad." His eyes answer "Just you wait," then he asks me whether I would like to stand at the peephole for a while.

"Gladly," I say. 
I stand up expectantly and look out until night falls. I see villages and fields, even a little town in the distance once, near a half-overgrown pond I see a group of soldiers resting amidst trucks, cannons and cattle. And I see a few sleepy stations with their platforms, crossings and station houses with green window boxes overflowing with flowers, I ask myself if these window boxes are by official regulation, because they hang on every station house and are all green. And I see people watching our train, whose faces I can't make out, but most of all I see trees that I had almost forgotten about, even though I am still a young man, lots of trees. Beeches and alders and birches and willows and pines, good god, all the trees I can see. One tree was responsible for my not being able to make it to violinist, and under one tree I became a real man, the wild boars came too late to prevent it. And under an unknown tree I lost my wife Chana, and a regulation wanted to prohibit trees to me forever. Some say that trees confuse my senses, there I stand and stand, sometimes even today I take a ride on a train in an area especially rich in trees, I like mixed woodland best. Until I hear Jacob's voice:" "Don't you ever want to go to sleep?"

\footnotetext{
"Let me stand a while longer," I say.

"But you can't see anything any more," I hear him say.

"Yes I can."
}

For I can still see the shadows of trees, and I can't sleep, we're going wherever we are going. 
KOMMENTAR 


\section{Zur Übersetzung von Jurek Becker \\ Jakob der Lügner}

Jurek Becker wurde 1937 in Lodz geboren, wuchs im Ghetto auf und musste einen Teil seiner Kindheit in den Konzentrationslagern Ravensbrück und Sachsenhausen verbringen. Seit 1960 ist er ein freischaffender Schriftsteller, zunächst in 0stberlin und seit einigen Jahren in Westberlin. 1971 erhielt er den Heinrich-Mann Preis und den Charles-Veillon Preis, 1974 den Bremer Literaturpreis. Jakob der Lügner ist Jurek Beckers erster Roman, erschienen im Jahr 1969 im Aufbau Verlag Berlin und Weimar. Andere Romane von Jurek Becker sind Irreführung der Behörden (1973), Der Boxer (1976), Schlaflose Tage (1978), Aller Welt Freund (1982).

Bei einem Besuch an der Deutschen Sommerschule am Pazifik im Sommer 1978 sprach Becker etwas über die Entstehung seines Romans Jakob der Lügner. Er wurde von inm auf Anregung seines Vaters geschrieben, der dem Jungen nach dem Ende des Krieges oft Geschichten aus der Zeit im Ghetto erzählte. Bei diesem Besuch an der Deutschen Sommerschule zeigte der Schriftsteller auch den ausgezeichneten Film, der in der DDR getreu nach dem Roman gedreht wurde.

In Jakob der Lügner handelt es sich um ein jüdisches Ghetto während des zweiten Weltkrieges. Jakob, einer der Ghettobewohner, überhört an einem Abend eine deutsche Radiosendung, in der mitgeteilt wird, dass die Russen vor Bezanika stehen. Diese Nachricht, die für Jakob die eventuelle baldige Befreiung der Ghettobewohner durch die Russen bedeutet, 
verbreitet sich schnell unter seinen Freunden. Aber da sich Tag für Tag im Ghetto nichts ändert, năhrt Jakob die Hoffnungen der bedrängten Juden mit selbsterfundenen Nachrichten, deren Kenntnis er damit begründet, dass er selbst im Besitze eines Radios sei, was natürlich nicht stimmt und schwer strafbar wäre. Die Anzahl der Selbstmorde unter den Ghettobewohnern geht nun zurück, doch die Befreiung der Juden durch die Russen tritt nicht ein. Der Roman endet mit der gänzlichen Evakuierung des Ghettos durch die Deutschen, und Jakob und seine Freunde werden in einem Zug ins grauenhaft Ungewisse transportiert.

In Meyers Taschenlexikonausgabe Schriftsteller der DDR heisst es unter Jurek Becker:

Beckers jüdischer Erzähltradition verpflichteter und von eigenen Erlebnissen gepragter Roman Jakob der Lügner (1968) zählt zu den wesentlichen Werken der DDR Literatur über die faschistische Schreckenszeit: er berichtet, zwei Erzahlebenen miteinander verwebend, in faszinierender atmosphärischer Dichte vom Menschlichbleiben unter unmenschlichen Bedingungen, vom stillen Heldentum Jakobs, des Lügners aus Menschlichkeit (Symbol des jüdischen Dulders), und seiner Leidensgefährten im Ghetto; die 'sich selbst und die anderen verspottende Ironie', der zuweilen 'makabre Witz' ( $W$. Joho) erzeugt eine Erzählweise, die scheinbar in krassem Widerspruch zur erschütternden Tragik des Geschehens steht, jedoch eine tiefe emotionaje Wirkung bei der Aufdeckung von Inhumanität und Barbarei erreicht."1

Melvin Kornfeld hat diesen Roman ins Englische übersetzt.2 Es handelt sich um eine Übersetzung, die aus vielen Grunden den feinen, leicht ironischen Stil einer von immer verschiedenen Perspektiven gesehenen Handlung in keiner Weise widergibt. Sie ist zuweilen nicht

1"Jurek Becker," Meyers Taschenlexikon, Schriftsteller der DDR (VEB Bibliographisches Institut, Leipzig, 1975).

2Jurek Becker, Jacob The Liar, trans. Melvin Kornfeld (New York and London: Harcourt Brace Jovanovich, 1975). 
leicht verständlich, schwerfällig geschrieben und langweilig zu lesen. Es überrascht nicht, dass die Übersetzung bald nicht mehr neu aufgelegt wurde.

Wie ist es möglich, einen guten Roman durch eine schlechte Übersetzung so stark zu verändern? Ich möchte versuchen zu zeigen, inwiefern ich meine Übersetzung fur gelungener halte als die von Melvin Kornfeld. Zunächst werde ich ganz allgemein ein paar Punkte erwännen, die mir für die Übersetzung eines literarischen Werkes wichtig zu sein scheinen, um anschliessend anhand von zwei Paragraphen aus dem Text herauszustellen, wie Kornfeld meiner Ansicht nach gegen diese Grundregeln des Übersetzens verstösst. Am Ende dieser Bemerkungen werde ich dann versuchen, die typischsten Übersetzungsfehler Kornfelds aufzuzählen und in Gruppen einzuordnen.

Natürlich ist das Ziel einer guten Übersetzung, dass der Leser nicht merkt, dass es sich um eine Übersetzung handelt. Diese soll also dem Originaltext so treu wie möglich bleiben, in der Sprache aber gleichzeitig frei genug sein, als dass es nicht den Eindruck einer übersetzung erweckt. Folgendes muss dabei beachtet werden:

1. Man muss die Welt des Romans, den Humor und den Stil des Autors genau verstehen, denn nur dann kann man seinem Original wirklich treu bleiben. Es darf also nicht passieren, dass man beispielsweise einem Jakob ein sprachliches Niveau und ein Vokabular in den Mund legt, die er im Orginaltext nicht hat, denn dann handelt es sich ja nicht mehr um denselben Jakob.

2. Man muss genug literarisches Feingefühı haben, um den Kommentar des Autors oder des Erzählers von dem inneren 
Monolog einer seiner Charaktere unterscheiden zu konnen. Die einzigen Anhaltspunkte fur eine solche Unterscheidung sind die Sprache und der Stil.

3. Man muss in beiden Sprachen mit idiomatischen Redewendungen ganz vertraut sein. Es darf nicht vorkommen, dass man einen idiomatischen Ausdruck wörtlich übersetzt, denn dann hat man das sprachliche Niveau verändert.

4. Man sollte lieber ein etwas weniger exakt übersetztes Wort benutzen als ein ausländisch klingendes.

5. Man muss Änderungen vermeiden, es sei denn sie sind aus Gründen des Stils oder der Verständlichkeit unbedingt erforderlich. Wenn man die Interpunktion oder die Verbzeiten verändert, oder ein aktives Verb in ein passives umwandelt, können sich Änderungen vollziehen, die den gesamten Roman verändern.

Die Beispielsparagraphen, anhand derer ich meine Übersetzung mit der von Melvin Kornfeld vergleichen möchte, stammen beide aus einem der früheren Kapitel des Romans. Mischa, Jakobs junger Freund und Mitarbeiter auf dem Bahndamm, hat bei der Morgenarbeit von diesem gerade erfahren, dass die Russen vor der Stadt Bezanika stehen, also von ihrem Ghetto nicht sehr weit entfernt sind. Diese Neuigkeit wird bald alle Ghettobewohner mit Freude und neuer Hoffnung erfüllen, da die Russen als Feinde der Deutschen die Ghettos sofort befreien werden. Jakobs Informationsquelle ist eine von inm zufällig überhörte deutsche Radiosendung. Er erklärt Mischa aus Zeitgründen aber nicht, wie er zu 
dieser guten Nachricht gekommen ist, sondern gibt stattdessen vor, selbst im Besitze eines Radios zu sein. Mischa ist in Rosa verliebt, Tochter des etwas theatralisch-pompösen ehemaligen Schauspielers Felix Frankfurter und seiner sympathischen Frau. Jedesmal wenn Mischa abends die Frankfurters besucht, um Rosa zu sehen, spielen Vater und Tochter gerade eine Partie Dame. Heute sitzt auch die Mutter dabei und näht an einem Hemd ihres Mannes. Rosa ist im Begriff das Spiel zu verlieren:

Sie hat ärgerlich abgewinkt, von Freude am Spiel keine Rede mehr, sie hat die Steine nur aus Gehorsam nicht umgeschmissen, und weil Mischa noch nicht da war, doch dann klopft es. Sie rennt eilig zur Tür und "̈ffnet, und Mischa kommt herein. Man begrüsst sich, Frankfurter fordert Mischa auf, Platz zu nehmen, Mischa setzt sich. Rosa raumt schnell die Steine und das Brett weg, bevor Mischa ihre verlorene Partie übernehmen kann. Oft schon hat er sich auf ihren Platz gesetzt, nach einem Ausweg gesucht, hat am Ende doch aufgeben mussen und Revanche gefordert. Frankfurter hat sie ihm gewährt, dann haben sie beide dagesessen und gegrübelt, und auf einmal war es so spät, dass Mischa gehen musste, bevor Rosa von inm etwas gehabt hat.

"Ihr habt gespielt?" fragt Mischa. "Wer hat denn heute gewonnen?" 3

Melvin Kornfeld übersetzt diesen Paragraphen folgendermassen:

She nodded, annoyed. There was no question now of any fun in the game. It was only out of deference that she didn't overturn the board. And because Misha wasn't there yet. But then there's a knock. She runs quickly to the door and opens it and Misha comes in. They greet each other. Frankfurter challenges Misha to a game. Misha sits down. Rosa clears away the checkers and the board before Misha can take over her lost game. He often takes her place, looks for a solution, but finally has to give up and ask for a return match. Frankfurter assents. Both of them sit there musing then. And suddenly it gets so late that Misha has to leave before Rosa has had any time alone with him. "You played a game today?" Misha asks. "Who won?

3Jurek Becker, Jakob der Lügner, (Frankfurt am Main: Suhrkamp Verlag, 1980), S.47

4 Becker, trans. Kornfeld, p.40 
Meine Übersetzung lautet so:

She waved her hand at him in anger, any fun in the game was out of the question now, it was merely out of obedience that she didn't push the checkers off the board, and because Mischa wasn't there yet, but then there is a knock at the door. She quickly runs to open it and Mischa comes in. They say hello, Frankfurter asks Mischa to have a seat, Mischa sits down. Rosa quickly clears away the checkers and the board before Mischa can take over her lost game. He has often sat down in her place, looked for a way out, given up in the end and asked for a return match. Frankfurter would then give him the chance, they would both sit and ponder and all of a sudden it would be so late that Mischa had to go before Rosa had had any time with him.

"You were playing?" asks Mischa. "Who won today?"

Wenn man die Kornfeldsche Übersetzung flüchtig liest, scheint es, als ob er den Originaltext Beckers mehr oder minder genau widergibt. Das stimmt auch, aber für eine gute Übersetzung langt das nicht. Man stösst bald auf folgende Probleme:

1. "She nodded, annoyed." Ich kann mich nicht besinnen, es je gesehen zu haben, dass jemand ärgerlich genickt hat, jedenfalls nicht in einer ăhnlichen Situation. Die ungeduldige Handbewegung, die so typisch ist, wenn man im Begriff ist, hoffnungslos zu verlieren, kommt dabei nicht auf ihre Kosten. Darum meine Übersetzung: "She waved her hand at him in anger."

2. "It was out of deference that she didn't overturn the board." "Out of deference" ist hier im Ton zu hochgegriffen. In dem Wort "deference" steckt eine gewisse Verehrung, die in dieser Situation falsch klingt und dem Ausdruck "Gehorsam" nicht recht entspricht. Auch würde man in Rosas Alter nicht gleich aus Ärger das ganze Spielbrett umkippen ("overturn the board"), sondern höchstens die Steine umwerfen, wie es auch im 
Orginaltext der Fall ist. Darum meine Übersetzung " . . it was merely out of obedience that she didn't push the checkers off the board."

3. "They greet each other. Frankfurter challenges Misha to a game." "Greet" scheint mir in dieser Situation etwas zu steif. Doch die Übersetzung "Frankfurter challenges Misha to a game" fü "Frankfurter fordert Mischa auf, Platz zu nehmen" ist vollkommen falsch. Und zwar ist es nicht nur dem wörtlichen Sinn nach verkehrt, sondern es rückt auch den übrigen Paragraphen psychologisch ins falsche Licht. Frankfurter spielt in dieser Szene eine eher passive Rolle. Es ist Mischa, der Rosas verlorenes Spiel retten will.

4. Wenn wir uns den Paragraphen, der im Beckerschen Originaltext mit "Oft" beginnt, ansehen, merken wir, dass Becker plotzlich vom Präsenz ins Perfekt umschwingt. Während die erste Hälfte des Paragraphen schildert, was jetzt im Moment gerade passiert, hören wir nach dem mit "oft" beginnenden Satz, was oft in änlichen Situationen zu geschehen pflegte. Kornfeld übersetzt beide Teile mit dem Präsenz und lässt dadurch den Unterschied zwischen diesen beiden Zeitstufen nicht stark genug hervotreten. Ich habe in dem zweiten Teil des Absatzes zunächst das Perfekt und später "would" gewählt, um das Routinehafte in den vergangenen Situationen hervorzuheben.

5. "Both of them sit there musing then." "To muse" scheint mir fü ein Damenspiel fehl am Platze, es ist zu verträumtpoetisch und ziellos, während "ponder" dem deutschen "grübeln" besser entspricht. 
6. Der letzte Satz des Paragraphen: "'Ihr habt gespielt?' fragt Mischa. 'Wer hat denn heute gewonnen?'" soll einen Höhepunkt dieser ganzen Spielszene bilden. Genau wie es vom Anblick des Spielbrettes und der Steine und Rosas eiligem Einräumen des Ganzen vollkommen klar wird, dass die beiden gespielt haben, so ist es natürlich aus derselben Situation vollig klar zu erlesen, dass Rosa (wie üblich) das Spiel verloren hat. Mischas Frage "Wer hat denn heute gewonnen?" hat den Akzent auf "heute" und ist ironisch gemeint. Kornfelds Übersetzung: "'You played a game today?' Misha asks. 'Who won?" enthält nichts von dieser Ironie, weil er das "today" an den falschen Platz gerückt hat.

7. Im Ganzen müsste man noch über die Interpunktion sprechen. Beckers Stil ist so frisch und ansprechend, zum Teil weil er eine überraschende Interpunktion benutzt, in der kurze Sätze durch Kommata voneinander getrennt sind und dann plötzlich in einem Punkt enden. In dieser Weise schlüpft er immer wieder in seine Charaktere hinein und spricht eigentlich durch sie. Der ganze erste Satz in diesem Absatz is von Rosas Perspektive gesehen. Wir stellen uns vor, wie sie abwinkt, wie sie sich zusammennehmen muss, um die Steine nicht vom Brett zu stossen, wie sie sehnlichst Mischa erwartet, und wie eine gewisse Lösung ihrer Gedanken und Gefühle durch Mischas Klopfen eintritt. Kornfeld uberspielt all das, indem er unabhängige Hauptsätze voneinander durch Punkte trennt. 
Nicht nur bekommt der Stil dadurch etwas Übersimples und Abgehacktes, sondern er hackt auch damit einen der wichtigsten stilistischen Kunstgriffe des Romans in Stücke: Beckers Talent besteht darin, dass er sich in die meisten seiner Charaktere durch die Sprache hineinprojeziert. Der Leser hat dauernd das Gefühl, dass er mal in Rosas Gefühlswelt, mal in Mischas, oder die einer anderen Person hineingleitet. Oft trennt Becker überraschend durch einen Punkt die innere Gedankenwelt einer Person von der konkreten Aussenwelt. In diesem Absatz: "... und weil Mischa noch nicht da war, doch dann klopft es." Das Klopfen ist gesehen als eine Erlösung für Rosas Ärger mit dem Spiel, aber es ist auch ein rein äusseres Geschehnis, das ihren Gedanken ein Ende setzt. Das nächste rein aussere Geschehen ist Mischas Platznehmen und ihr Wegräumen der Steine, das dann wieder zu Träumereien über das, was so oft schon geschehen ist und dieses Mal nicht wieder passieren soll, führt. Wenn man jeden Satz in gleicher Weise als einen unabhängingen von Punkten abgeschlossenen Hauptsatz widergibt, wird dieses Widerspiel zwischen äusserem Geschehnis und Gedanken zerstört.

Der zweite Paragraph, den ich gewăhlt habe, kommt einige Seiten später. Wir befinden uns aber noch in demselben Kapitel. Es stellt sich heraus, dass Mischa heute Abend gekommen ist, um der Familie Frankfurter die gute Nachricht der vor Bezanika stehenden Russen zu bringen. Er überlegt sich noch, wie man am besten diese Nachricht übermittelt, denn er ist sich genau darüber im $k l a r e n$, dass die 
Ankündigung von Jakobs vermeintlichem Radio nicht mit Freude begrüsst werden wird (Radiohören war im Ghetto natürlich auf Todesstrafe verboten), dass aber die Ankunft der Russen diesen Schock wohl mindern wird. Da kommt es zu einem grossen Missverständnis zwischen inm und der Familie Frankfurter: sie sprechen von der grossen Neuigkeit im Ghetto, er denkt sie meinen die Befreiung durch die Russen, sie aber sprechen von einem Baby, das gerade im Ghetto geboren wurde. Nun wird die Situation immer verwickelter, Mischa wird sich plotzlich darüber klar, dass, wenn er jetzt von der Russenbefreiung beginnt, alle sich darüber wundern werden, dass er von solch grossen Neuigkeiten nicht sofort gesprochen habe. Darum steht er plötzlich auf, um endlich davon anzufangen, aber ehe er sich recht besinnt, hört er sich Herrn Frankfurter um die Hand seiner Tochter bitten. Dann geht es folgendermassen weiter:

Rosa entdeckt etwas an ihrem Fingernagel, das sie mit Haut und Haaren beschäftigt, etwas so Wichtiges, dass ihr Gesicht rot wird und anfängt zu glühen, sie haben vorher kein Sterbenswort davon gesprochen, und eigentlich gehört es sich wohl so. Frau Frankfurter beugt sich tiefer über das Hemd, das noch längst nicht klein genug ist, die meiste Arbeit macht der Kragen, weil auf genauesten Sitz grosser Wert gelegt wird. Mischa geniesst seinen Einfall, gelungen oder nicht gelungen, Frankfurter ist verblüft und wird etwas sagen. Er ist dran mit einem Wort, eine höfliche Frage verdient eine Antwort, und wenn die Frage noch so abwegig ist, wie es vorerst scheint, er wird eine Brücke bauen zu der grossen Neuigkeit, und das wird auch gleichzeitig die Erklärung sein, warum erst jetzt. Das ist Mischas Plan, in grösster Eile entworfen und gar nicht so schlecht, Felix Frankfurter wird eine Brücke bauen, er ist an der Reihe, alle warten auf Antwort. 5

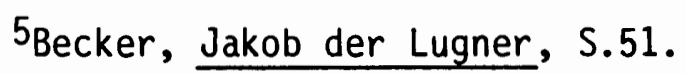


Und nun Kornfelds Ubersetzung:

Rosa discovers something on her fingernail which occupies her completely, something so important that she blushes and begins to glow. They hadn't spoken about it at all, but it's really quite fitting. Frau Frankfurter hunches deeper over the shirt, which is still a long way from being small enough. The collar is causing the greatest difficulty, because of her meticulousness that it fit properly. Misha is enjoying his brainstrom-successful or not. Frankfurter is bewildered, but will manage to say something. He is about to answer. A polite question deserves an answer, even if the question is wrong-headed. As it seems now, it will open a way to the explanation as to why Misha asked just now. That is Misha's plan conceived in the utmost haste and really not so bad. Felix Frankfurter will open a way. It's his turn. Everybody is waiting for a reply. 6

Meine Übersetzung:

Rosa discovers something on her fingernail which engrosses her totally, something so important that her face turns red and begins to glow, they had never spoken one word about it before, which would really have been the proper way. Frau Frankfurter hunches deeper over the shirt which is not nearly small enough yet, the collar is the hardest because one is fussy about an exact fit. Mischa is enjoying his bright idea, successful or not, Frankfurter is baffled and about to say something. It's his turn to speak, a polite question deserves an answer, misguided as this question is or at this point appears to be, he will build a bridge to the big news item and that will also be the explanation as to why not until now. That is Mischa's plan, conceived in the greatest hurry and not all that bad, Felix Frankfurter will build a bridge, it's his turn, everyone is waiting for an answer.

Hier ist meine Kritik an der Übersetzung Kornfelds:

1. Die Wortwahl ist oft dem deutschen Originaltext im Klima nicht entsprechend. Zum Beispiel:

a. "Occupies her completely" ist zu blass und intellektuell und gibt "das sie mit Haut und Haaren beschäftigt" zwar im Sinn nicht aber im Sprachniveau recht wider. Ich habe darum "which engrosses her totally" gewăhlt.

6Becker, trans. Kornfeld, S. 44. 
b. "They hadn't spoken about it at all" ist auch viel blasser als ". . . sie haben vorher kein Sterbenswort davon gesprochen." Meine Úbersetzung: " . . . they had never spoken one word about it before."

c. "Misha is enjoying his brainstorm" scheint mir unnötig steif für "Mischa geniesst seinen Einfall." Ich habe das mit "Mischa is enjoying his bright idea" übersetzt.

d. "Frankfurter is bewildered" fü "Frankfurter ist verblüfft" ist auch nicht ganz parallel. "Bewildered" hat etwas von "verstört, verwirrt, bestürzt", das in "verblüfft" eigentlijich nicht steckt. "Baffled" scheint mir genauer in der Ubertragung.

e. "Felix Frankfurter will open a way" für "Felix Frankfurter wird eine Brucke bauen" gibt den Gedanken nicht wider, dass die negative Antwort, die Mischa auf seinen Heiratsantrag erwartet und von der er weiss, dass sie sich auf die unmöglichen Lebenszustände im Ghetto gründet, die Brücke bilden wird zu der Befreiungsnachricht, die er ja immer noch nicht hervorgebracht hat.

2. Kornfeld macht in diesem Absatz drei Fehler, die von Bedeutung sind:

a. Er übersetzt Beckers "Und eigentlich gehört es sich wohl so", d.h. eigentlich hätte Mischa mit Rosa erst über seinen Heiratsantrag sprechen sollen mit: "but, it's really quite fitting." Das heisst, Kornfelds Ubersetzung nach war es gerade richtig, dass Mischa darluber nicht erst mit Rosa gesprochen hat. Das ist natürlich absurd.

b. Im Originaltext heisst es: "Frau Frankfurter beugt sich tiefer über das Hemd, das noch längst nicht klein genug ist, die meiste Arbeit macht der Kragen, weil auf genauesten Sitz grosser Wert gelegt wird." Becker erzăhlt verschiedentlich im Laufe des Romans, wie sehr Frau Frankfurter den Wünschen ihres Mannes folgt und deutet an, dass sie zeitweilig darunter gelitten hat 7 "Sie ist inm bisher immer gefolgt, ohne zu fragen, sie hat oft nur erraten, was zu tun sei, es war nicht immer gut." Hier in unserem Absatz bemüht sie sich so sehr um das Hemd, nicht weil ihr an einem möglichst korrektfen Sitz liegt (Kornfeld: ". . because of her meticulousness that it fit properly"), sondern aus Angst vor inm.

7Becker, Jakob der Lügner, S.57. 
c. Im Originaltext Beckers heisst es: "...er (Mischas Einfall, plótzlich um Rosas Hand zu bitten statt die Nachricht von den Russen anzukündigen) wird eine Brllcke bauen zu der grossen Neuigkeit, und das wird auch gleichzeitig die Erklärung sein, warum erst jetzt." Das "warum erst jetzt" bezieht sich auf warum Mischa erst jetzt mit der Befreiungsnachricht herausrückt, nicht warum er erst jetzt um Rosas Hand bittet, denn diese Bitte kommt ja gerade für alle überraschend früh und nicht spät. Darum ist Kornfelds Übersetzung "as to why Mischa asked just now" falsch.

3. Ein letztes Wort noch zu der Interpunktion, mit der Kornfeld sich ganz uber Beckers Stil hinwegsetzt. In dem obengenannten Abschnitt ist von drei Menschen direkt die Rede: Rosa, Frau Frankfurter und Mischa. Herr Frankfurter selbst spielt nur in den Gedanken dieser drei eine Rolle. Er wird mehr wie eine Naturkatastrophe behandelt, mit der die anderen drei sich befassen müssen. Wie erzählt uns Becker, was in den Köpfen dieser drei vorgeht? Wiederum indem er sich ganz in sie hineinversetzt, so dass man meint, ihre Gedanken wortwörtlich zu hören: Rosa, ihre Fingernägel, das "kein Sterbenswort" und "eigentlich gehört es sich wohl so", sind nicht Kommentare des Autors, sondern direkte Gedanken und Gefühte Rosas. Durch einen Punkt wird Rosa von Frau Frankfurter getrennt. Diese rackert sich mit dem Hemd ihres Mannes ab, während sie sich in Gedanken mit seinen hohen Erwartungen betreffs des Sitzes beschäftigt. Dann ein kurzer Satz über Mischa und Frankfurter, dann Mischas Gedanken, man hört inn gleichsam sprechen: "er ist dran", "eine hofliche Frage verdient eine Antwort", "er wird eine Brücke bauen", U.s.w. Im letzten Satz sind dann alle drei Personen noch einmal zusammengefasst: 
"Alle warten auf Antwort", was ja eigentlicht nicht stimmt, denn Frankfurter selbst wartet natürlich nicht auf seine eigene Antwort, aber es ist Beckers Art, noch einmal zu unterstreichen, dass "alle" bedeutet: alle die, deren Gedanken ich Euch in diesem Paragraphen geschildert habe. Dadurch dass Kornfeld alle diese Satzeinheiten auseinanderreisst und durch Punkte verselbständigt, wird dem Leser die feine symphonisch-psychologische Arbeit Beckers in seiner Übersetzung nicht klar.

Aus diesen und vielen anderen Beispielen konnte man die 11 Ubersetzungsfehler Kornfelds in folgende Gruppen einteilen:

1. Änderungen in der Interpunktion fallen vielleicht zunächst am stärksten auf. Bei Kornfeld besteht eine solche Änderung darin dass er, wie bereits erwänt wurde, sehr häufig Kommata durch Punkte ersetzt. Das hat fü die Übersetzung folgende negative Folgen:

a. Der Stil bekommt etwas zu Simples und Abgehacktes, das nicht nur dem Stil Beckers nicht entspricht, sondern auch oft in einem merkwürdigen Kontrast zu dem Vokabular Kornfelds steht, das häufig wiederum intellektueller und weniger sprachgebräuchlich ist als das des deutschen Originaltextes.

b. Durch diese Punkte in der Kornfeldschen Übersetzung wird der Stimmenwechsel verwischt zwischen Autor und innerem Monolog der Charaktere oder auch zwischen äusserem und innerem Geschehen. 
2. Falsche Übersetzung eines Wortes (die von nun an folgenden Zitate beziehen sich von links nach rechts jeweils auf Beckers Originaltext, auf die Übersetzung von Melvin Kornfeld und auf meine Übersetzung. Die angegebenen Zahlen deuten auf die entsprechenden Seiten der jeweiligen Ausgaben hin):

Becker

7: ich empfinde es so es so

11: aus dem Ghetto

14: kaum ein Mensch redet einen anderen mit "Herr Wachhabender" an

25: "Aber du musst wissen, dass ich neunundzwanzig. . ." (Gemeint ist das Jahr 1929)

26: Immernin handelt es sich um das Beste vom Besten (Gemeint ist die Nachricht, dass die Russen vor Bezanika stehen)

69: Alles wird mir wieder gehören, was ich früher einmal hatte, alles bis auf die erschossene Chana

94. Jakob und Kowalski sind wieder ein einsames Paar. . .
Kornfeld

3: I find it so

7: into the ghetto

9: since no one is talking to anyone in charge

19: "But you must know that I'm 29."
Meine Übersetzung

that is how I feel about it

out of the ghetto

who would ever address another with "Mr. Officer on Duty"

"but you should know that in 29. .."
20: Nevertheless it After all what was a question of the could be better best possible alternatives.

60: Everything I had before will once again belong to me, everything including my Chana who was shot to death.

84: Jacob and Kowalski And again Jacob are once again a love- and Kowalski are a ly pair.
Everything I used to own will be mine again, except for my wife Chana who was shot. lonesome pair. . 
il

3. Falsche Ubersetzung eines idiomatischen Ausdrucks:

11: . . man hätte

Lust, ein wenig zu

plaudern, der Humor

soll nicht zu kurz

kommen.

22: Das mir das

nicht noch mal

passiert, verstanden?

22: . . verflucht

oder gesegnet se $i-$

en alle Katzen

oder Aufseher

37: an diesem

blauen Tag bin ich

der Austeiler. Ich

weiss von nichts,

ich erfahre immer

alles zuletzt, die

Sonne făllt mir auf den Wecker, ich bin wütend.

48: Wenn er über das Theater redet, wo sich, wenn man

ihm glauben soll, die irrsinnigsten Dinge zugetragen haben, so gibt es dort keinen Schritt und keinen Blick mit denen es nicht irgendeine besondere Bewandtnis auf sich hat.

55: Er kann, und das tut er, alle Zweifel beseitigen, es ist so weit, der Plan ist aufgegangen

76: "Wo arbeitet deine Frau?" Da und $\mathrm{da}$, hat Nuriel geantwortet.
6: You might even wish to chat a bit, if it weren't so serious.

17: Don't let it happen to me again, you hear!

18: Whether or not all cats and supervisors are cursed or blessed

31: On this clear day I am the ladler. I don't know about anything, I always find things out last. I woke up in a bad mood. I'm furious.

40-41: Whenever he speaks about the theater, where--if he's to be believed-the craziest things happened, he does not miss the slightest opportunity to relate things to himself.

47: He can--and he does--dispel all doubts. It has come to that; his confidentiality disappears.

67: "Where does your wife work?" Right then and there, Nuriel replied.
.. one would

like to chat a while and let some humor enter into it.

don't ever let that happen again, do you hear?

-. damned or blessed be all cats and supervisors

On this blue day I am the ladler. I don't know anything, I am always the last one to know, the sun is getting to me, I am furious

Whenever he talks about theater, where, if one is to believe him, the craziest things happened, there isn't a step or a glance that doesn't have some special relevance.

He can, and he does, dispel all doubts, now is the time, his plan worked.

"Where does your wife work?" In such and such a place, Nuriel answered. 
86: . . er möge doch gütigst zusehen, was sich da machen liesse

94: Jakob und Kowalski sind wieder ein einsames Paar, beide um eine Sorge leichter, die Sache wăre ausgestanden.

106: Jetzt hilft nur noch ein Wunder, her mit dem ersten besten
76: Let Him please see what at least is going on...

84: Jacob and Kowalski are once again a lovely pair, both liberated from a worry that the matter would have come to pass.

95: Only a miracle can help now, so act upon your first impulse
-. wouldn't He kindly see what can be done about it

And again Jacob and Kowalski are a lonesome pair, they have both been freed of one worry, at least that's over with.

Only a miracle can help now, let's have one then.

"

4. Korrekte Ubersetzung mit falschen Nuancen. Als Jakob, z.B. auf dem Klosett der Deutschen sitzt, (was den Ghettobewohnern natürlich strengstens untersagt war), um deren Zeitungsblättchen zu lesen und sich so über den Stand des Krieges zu informieren, klopft ein deutscher Soldat an die Klosettür, und Jakob hält sein letztes Stündchen für geschlagen. Es heisst:

106: . dann sieht so lächerlich die besagte letzte Stunde aus.
95: .. the aforementioned last hours would look so ridiculous.

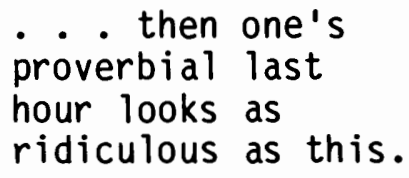

Es kommt in einer Übersetzung leicht vor, dass man sich im Sprachniveau eines Wortes vergreift. Kornfeld hatte offenbar Schwierigkeiten mit Beckers bewusst einfachem Stil und übersetzt ihn häufig in einer zu praziösen, hochtrabenden Weise. Hierfür nur einige Beispiele: für "Nevenprobe" "a test of his nerves", fü "Einfall" "brainstorm", für "besagt" "aforementioned", u.s.w. 
Auch eine unnötig abstrakte Widergabe eines konkreten Begriffes kann die Bildlichkeit einer Beschreibung zerstören oder ihr schaden. Zum Beispiel:

149: Jakob geht gehobenen Herzens zur Arbeit, wer seine Haltung und den zugigen Schritt bemerkt. .
137: Jacob is going to work in high spirits. Whoever notices his attitude and his jaunty stride. .
Jacob goes off to work with a light heart, whoever notices his composure and his jaunty stride. .

5. Hauptänderungen in den Verbzeiten:

a. Übersetzung des deutschen Perfekts mit englischem Plusquamperfekt:

22: Sein Dahinscheiden ist von gewissen mysteriösen Umstähden begleitet gewesen.

47:... und in seinem Mund steckt eine Pfeiffe, Meerschaum, die lange schon vergessen hat wie Tabak schmeckt.

235: "Wahrscheinlich sind die Deutschen bis jetzt die ganze Zeit marschiert."

237: "Was willst du denn von Onkel Jakob?" fragt Lina, als der übrige Gesprächsstoff sich bald erschöpft hat.
17: His departure from this world had been accompanied by mysterious cirstances.

39: In his mouth a pipe, a meerschaum, that had long forgotten the taste of tobacco.

221: "Probably the Germans had been advancing the whole time till then."

222: "What do you want from Uncle Jacob?" asks Lena, after the remaining conversational matter had soon been exhausted.
His passing away was accompanied by certain mysterious circumstances.

.. in his mouth a pipe, a Meerschaum, which has long since forgotten what tobacco tastes like.

"The Germans have probably been advancing the whole time up until now."

"What is it you want from Uncle Jacob?" Lena asks, once they have exhausted all other topics of conversation.

Ich könnte hierzu noch viele zusätzliche Beispiele zitieren. Kornfelds Plusquamperfekt entspricht deswegen nicht dem 
Beckerschen Perfekt, weil Becker durch den Gebrauch des Perfekts zwar natürlich $\mathrm{klar}$ macht, dass die Handlung in der Vergangeheit liegt, aber dass sie auch gleichzeitig in die Gegenwart eingreift (nicht umsonst wird das Perfekt durch das Präsenz des Hilfsverbs und ein Partizip gebildet). Wenn man nun das Hilfsverb in die Vergangenheit setzt, also aus dem Perfekt ein Plusquamperfekt macht, unterstreicht man damit, dass die Handlung bereits in der Vergangenheit abgeschlossen war, was aber nicht der Fall ist. Es ist stilistisch ein Unterschied, ob man sagt: "... eine Pfeife, Meerschaum, die lange schon vergessen hat, wie Tabak schmeckt", oder "... a pipe, a meerschaum, that had long forgotten the taste of tobacco." In dem deutschen Satz schwingt das Vergessen noch mit in die Gegenwart hinein, man fühlt gleichsam, wie der Raucher noch jetzt wünscht, seine Pfeife möge sich noch an Tabakgeschmack erinnern. In der englischen Übersetzung von Kornfeld wird diese Nuance verwischt.

b. Übersetzung des deutschen Präsenz mit englischem Imperfekt oder Perfekt:

Becker gebraucht in seinem Roman das Präsenz aus folgenden verschiedenen Grüden:

1. Um die Eržahlung lebendiger zu gestalten. Beispiele: 205: Preuss unter- 191: Preuss inter- Preuss interrupts bricht seine rupted his absoludurchaus prägnante tely pithy analysis. analysis Analyse.

206: Schon von 192: Even from the den oberen Stufen upper steps he has herab ruft er... called down. . . his rather pithy

Still standing on the upper steps he calls down.. 
2. Um sich (wie wir es bei der Behandlung der

Interpunktion schon sahen) in seine Charaktere

hineinzuprojezieren und sie so in einer Art innerem

Monolog sprechen zu lassen. Zum Beispiel:

33. Mischa ist es so egal, was das heisst ein Radio im Ghet to
27: Misha couldn't care less about what a radio in the ghetto meant.

\begin{abstract}
Mischa couldn't care less about what it means, a radio in the ghetto.
\end{abstract}

In diesem Beispiel hatte Jakob vorher zu Mischa gesagt: "Und vor allem halt das Maul. Du weisst, was das heisst, ein Radio im Ghetto." In Mischas Kopf geistert noch das Echo von Jakobs Warnung herum, darum ist es wichtig, seine Gedanken auch im Präsenz widerzugeben.

$\begin{array}{lll}\text { 226: Vor der Haus- } & \text { 211: At his front } & \text { At his front door } \\ \text { tür fällt Mischa } & \text { door something un- } & \text { something unpleas- } \\ \text { etwas Unangenehmes } & \text { pleasant comes to } & \text { ant occurs to } \\ \text { ein, keine Arbeit } & \text { Misha's mind. No } & \text { Mischa, no work } \\ \text { bedeutet kein } & \text { work means no lunch } & \text { means no lunch } \\ \text { Mittag heute, er } & \text { today. He asks } & \text { today, he asks Rosa } \\ \text { fragt Rosa, ob sie } & \text { Rosa if she happens } & \text { if she happens to } \\ \text { zufa'llig ihre } & \text { to have her food } & \text { have her food } \\ \text { Lebensmittelmarken } & \text { stamps with her. } & \text { stamps with her. } \\ \text { bei sich hat. Die } & \text { They were unfor- } & \text { Unfortunately } \\ \text { liegen leider zu } & \text { tunately at home. } & \text { they're at home, } \\ \text { Hause, er denkt, } & \text { He thinks, that's } & \text { that's all we need, } \\ \text { auch das noch. } & \text { all he needs } & \text { he thinks. }\end{array}$

Wenn Kornfeld hier sagt "They were unfortunately at home", dann zerbricht er das, was als Gedankengang Mischas hier widergegeben wird.

3. Um etwas als zeitlich ungebunden, allgemein und immer zutreffend herauszustellen. Zum Beispiel:

39. Auf der anderen Seite hat Jakob anfähglich unter der unabänderlichen Tatsache
33. On the other end, at first Jacob suffered from the undeniable fact that while pancakes can be
On the other end Jacob suffered initially from the unalterable fact that one can eat 
gelitten, dass man

zwar jeden Tag

Puffer essen kann,

nicht aber sich

die Haare schnei-

den lassen. consumed daily, you

didn't need a daily

haircut. potato pancakes daily, but not have one's hair cut every day.

c. Progressives Präsenz in der englischen Übersetzung für deutsches Präsenz. Zum Beispiel:

Als Jakob sich überlegt, was für Nachrichten er sich für sein nichtexistentes Radio ausdenken könnte, um seine Freunde über diese bittere Zeit hinwegzubringen, heisst es:

\begin{tabular}{|c|c|c|}
\hline $\begin{array}{l}\text { 151: Denn das Uber- } \\
\text { schreiten des } \\
\text { Flusses ist nicht } \\
\text { ganz ohne Probleme, } \\
\text { so leicht machen } \\
\text { wir es den Russen } \\
\text { nicht, die Deut- } \\
\text { schen haben die } \\
\text { einzige Brücke ge- } \\
\text { sprengt, hat sich } \\
\text { Jakob gedacht. } \\
\text { Bevor der Vor- } \\
\text { marsch fortgesetzt } \\
\text { werden kann, muss } \\
\text { eine behelfsmăs- } \\
\text { sige Pontonbrücke } \\
\text { gebaut werden, und } \\
\text { darüber vergehen } \\
\text { drei oder vier } \\
\text { Tage. Dann ist } \\
\text { auch das erledigt, } \\
\text { die Russen mar- } \\
\text { schieren auf das } \\
\text { Städtchen Tobolin, } \\
\text { aus dem die Deut- } \\
\text { schen eine Art } \\
\text { Festung gemacht } \\
\text { haben. Die hält } \\
\text { wieder drei Tage } \\
\text { stand, sie wird }\end{array}$ & $\begin{array}{l}\text { 139: Because the } \\
\text { crossing of the river } \\
\text { is not entirely de- } \\
\text { void of problems. } \\
\text { We're not making it } \\
\text { that easy for the } \\
\text { Russians. The Ger- } \\
\text { mans have blown up } \\
\text { the only bridge, Jacob } \\
\text { thought. Before the } \\
\text { advance can be con- } \\
\text { tinued a makeshift } \\
\text { pontoon bridge must } \\
\text { be built and on that } \\
\text { the Russians spend } \\
\text { three or four days. } \\
\text { Then that's finished } \\
\text { too, and the Russians } \\
\text { are advancing to the } \\
\text { town of Tobolin of } \\
\text { which the Germans } \\
\text { have made a kind of } \\
\text { fortress. It too } \\
\text { will hold out for } \\
\text { three days. It is } \\
\text { being surrounded. . }\end{array}$ & $\begin{array}{l}\text { Because the cross- } \\
\text { ing of the river } \\
\text { is not entirely } \\
\text { without difficult- } \\
\text { ies, we're not } \\
\text { going to make it } \\
\text { that easy for the } \\
\text { Russians, the Ger- } \\
\text { mans have blown up } \\
\text { the only bridge, } \\
\text { Jacob decided. Be- } \\
\text { for the advance can } \\
\text { be continued, a } \\
\text { makeshift pontoon } \\
\text { bridge must be } \\
\text { built, and that } \\
\text { takes three or four } \\
\text { days. Then that's } \\
\text { finished and the } \\
\text { Russians march } \\
\text { towards the little } \\
\text { town of Tobolin, of } \\
\text { which the Germans } \\
\text { have made a kind of } \\
\text { fortress. It again } \\
\text { holds out for three } \\
\text { days, it is sur- } \\
\text { rounded. . . }\end{array}$ \\
\hline
\end{tabular}


Das progressive Präsenz am Ende dieses Abschnitts in der Übersetzung Kornfelds verwischt die Tatsache, dass es hier ja nicht um wirkliche Ereignisse geht, sondern dass Jakob sich das alles zusammenf ant as iert.

d. Falsche oder ungenaue Übersetzung des Konjunktivs. Zum Beispiel:

20: Der Korridor

ist wieder leer, man kann sich fast schon darauf verlassen, rechne man inn zu den kleineren Gef ahrenquellen.

133: Jetzt sind
wir alle gleich
gescheit, nichts
unterscheidet uns
mehr, nichts bis
auf euren Glauben,
ich wäre einmal
ein Besonderer
gewesen.

267: In drei, vier Tagen k"önte er sich wieder besser fühlen
15: The corridor is empty once more. You can almost be sure of that, if you should consider that among the more minor sources of danger

121: Now we're all equally clever. Nothing differentiates us any longer. Nothing except your faith that I would have been a special person someday.
The hallway is empty again, one can almost count on it, let's consider it as a minor source of danger.

251: In three or four In three or four days he would be feel-days he could be ing better again feeling better again

Now we are all equally clever, nothing distinguishes us any more, nothing but your belief that at one time I was someone special.

Wăhrend die ersten beiden Beispiele eines falsch übersetzten Konjunktivs eben einfach falsch und darum verwirrend sind, können wir an dem dritten Beispiel wieder sehen, wie Kornfeld die Person des Autors von der der Charaktere nicht trennt. Jakob fühlt sich nicht gut, aber sagt sich, dass er sich möglicherweise in ein paar Tagen wieder besser fühlen könnte. Nur der Autor selbst weiss zu diesem Zeitpunkt, ob Jakob sich in drei oder vier Tagen erholen wird oder nicht. Kornfeld 
übersetzt das "könnte" mit "would" und verringert dadurch diesen Zweifel Jakobs, an dem der Leser ja teilhaben soll.

Zusammenfassend wäre zu sagen, dass die Übersetzung von Melvin Kornfeld ein gutes Beispiel dafür ist, wie man zwar inhaltsmässig einen Text mehr oder minder korrekt übersetzen kann, sich aber durch eine Anzahl zunächst vielleicht unwichtig scheinender Änderungen in der Idiomatik, der Wortwahl, der Interpunktion und den Verbzeiten so von dessen Kern entfernen kann, dass ein Werk wie der Jakob der Lügner von Jurek Becker, das durch seinen feinen Humor, seine Menschenkenntnis, seine Enfachheit und Geschlossenheit glänzt, nun plötzlich nichts mehr darstellt als eine stilistisch grobe und holprig geschriebene Geschichte einiger psychologisch oberflächlich ausgearbeiteter Ghettobewohner im zweiten Weltkrieg. 


\section{BIBLIOGRAPHIE}

Albrecht, Gunter. Meyers Taschenlexikon, Schriftsteller der DDR. Leipzig: VEB Bibliographisches Institut, 1975.

Becker, Jurek. Jakob der Lügner. Frankfurt am Main: Suhrkamp Verlag, 1980 .

Becker, Jurek. Jacob the Liar. Trans. Melvin Kornfeld. New York and London: Harcourt Brace Javanovich, 1975. 